UNIVERSIDADE DE SÃO PAULO

FACULDADE DE FILOSOFIA, LETRAS E CIÊNCIAS HUMANAS

DEPARTAMENTO DE FILOSOFIA

\title{
A UNIDADE DA VERDADE EM ERASMO
}

Sílvio Lúcio Franco Nassaro 
UNIVERSIDADE DE SÃO PAULO

FACULDADE DE FILOSOFIA, LETRAS E CIÊNCIAS HUMANAS

DEPARTAMENTO DE FILOSOFIA

\title{
A UNIDADE DA VERDADE EM ERASMO
}

\author{
Sílvio Lúcio Franco Nassaro
}

Dissertação apresentada para o Programa de Pós-Graduação em Filosofia da Faculdade de Filosofia, Letras e Ciências Humanas da Universidade de São Paulo, para obtenção do título de Mestre em Filosofia.

Orientadora: Profa. Dra. Maria das Graças de Souza

São Paulo

2005 
Aos que amo e aos que me amam. 


\section{AGRADECIMENTO}

À Maria das Graças de Souza, pelo acolhimento do projeto desta pesquisa e pelo constante estímulo e iluminação. 


\section{RESUMO}

Se Petrarca, como inaugurador do humanismo no século XIV já se opusera à teologia escolástica, levada ao impasse entre fé e razão com os argumentos averroistas e depois ockhamistas e entregue às disputas dialéticas; propugnara pela recuperação da erudição clássica sustentando como cristão que nenhum guia deve ser desprezado se mostra o caminho da salvação e indicara que ninguém, a não ser o cristão, sabe a quem e de que maneira confessar - cui et qualiter confitendum sit - será Erasmo de Rotterdam no século XVI que, afastando-se das sutilezas daqueles que desde o Medievo queriam compreender os mistérios da fé fazendo a teologia se apoiar na filosofia enquanto reflexão sobre o Ser conforme o cânone platônico-aristotélico, proporá que a ciência das coisas divinas e humanas deve ser buscada antes na filosofia enquanto tradição retórica de reflexão sobre os problemas do Homem e, explorando ao máximo as possibilidades da nascente imprensa, explicará socraticamente, através de seus milhares de Adagia, Colloquia, Litterae, traduções e edições princeps, para uma Europa estupefata, angustiada e vacilante entre o renascimento da grandeza antiga e o radicalismo religioso de católicos e reformados, porque e como, decisivamente, devem ser lidos os autores greco-latinos e entendida a precedência da Revelação cristã em relação ao paganismo e às invenções - inventiones dos outros povos. Neste quadro de rupturas, se insere com relevo os Antibárbaros, designado pelo seu autor para a edição de sua Opera Omnia como o primeiro livro da primeira ordem que é justamente aquela voltada ao ensino dos textos antigos - ad institutionem litterarum - livro que traz a suma de seus argumentos pela pacífica unidade da verdade. 


\begin{abstract}
If Petrarch, as inaugurator of Humanism in the XIV Century, was already contrary to the Scholastic Theology - pushed into the impasse between Faith and Reason with Averroists arguments and then Ockamists, and involved in dialectical debates - battled for the restoration of the Classical erudition standing as a Christian that none guide should be contempt if it points out the salvation path; and indicated that no one but the Christian knows to whom and in which manner to confess - cui et qualiter confitendum sit - it will be Erasmus from Rotterdam in XVI Century that, being far from the subtleness from those whose, from the Middle Ages, wanted to understand the Faith Mysteries making the Theology be supported by the Philosophy as reflection about the Being according to the Platonic-Aristotelian Canon, will propose that the science of holly and human things should be chased prior in the Philosophy as Rhetorical tradition of reflection about human problems and, exploring uttermost the possibilities of the emerging press, will explain in a Socratic manner, throughout his thousands of Adagia, Colloquia, Litterae, translations and princeps editions, for a perplex, anxious and oscillating Europe between the renaissance of the ancient greatness and the religious radicalism of Catholics and Protestants, why and how, definitely, should be read the Greek-Latin authors and grasped the precedence of Christian Revelation regarding the Paganism and the inventions -inventiones- of other peoples. In this landscape of ruptures, it inserts with weight the Antibarbarians, designated by its author for his Opera Omnia edition, as the first book of the prime order that is exactly that one made for the instruction of classical texts -ad institutionem litterarum- a book that summarizes his arguments for the peaceful unity of Truth.
\end{abstract}

PALAVRAS-CHAVE: Renascença, Humanismo, Erasmo, Retórica, Antibárbaros. KEY WORDS: Renaissance, Humanism, Erasmus, Rhetoric, Antibarbarians. 


\section{SUMÁRIO}

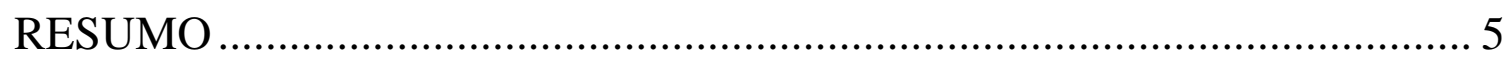

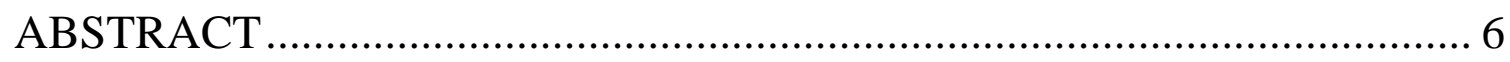

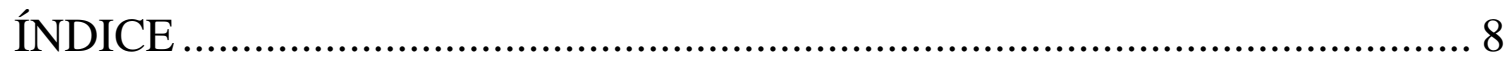

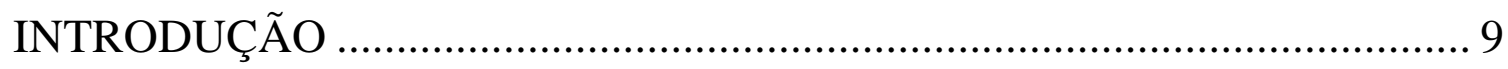

CAPITULO I - FILOSOFIA E RETÓRICA EM ERASMO............................ 23

CAPÍTULO II - ERASMO E A CRISE DA UNIDADE DA VERDADE..... 58

CAPÍTULO III - OS ANTIBÁRBAROS .................................................... 93

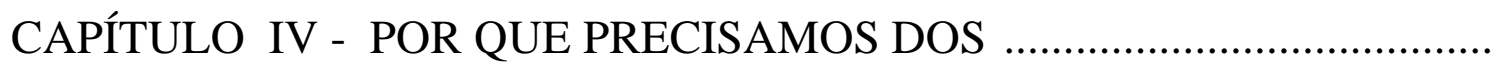

STUDIA HUMANITATIS............................................. 132

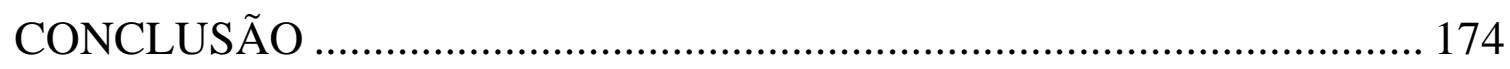

REFERÊNCIAS BIBLIOGRÁFICAS ................................................... 180 


\section{ÍNDICE}

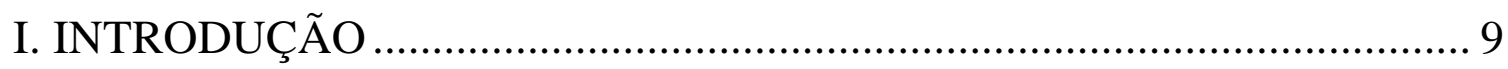

II. CAPITULO I

FILOSOFIA E RETÓRICA EM ERASMO_........................................... 23

III. CAPÍTULO II

ERASMO E A CRISE DA UNIDADE DA VERDADE ........................... 58

IV. CAPÍTULO III

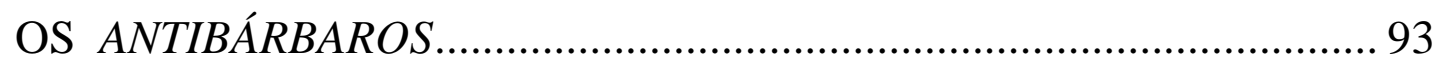

V. CAPÍTULO IV

POR QUE PRECISAMOS DOS STUDIA HUMANITATIS ................... 132

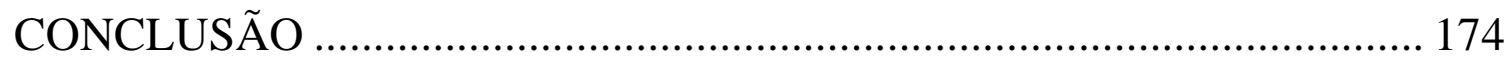

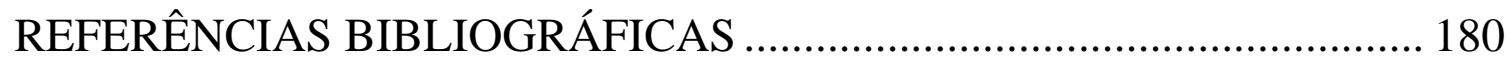




\section{INTRODUÇÃO}

Primeiramente, como um bom auspício, lembremos que os antigos acreditavam no poder inspirador do sopro divino das Musas, dentre elas, especialmente Clio, que invocavam do alto antes de tratar da história vivida pelos homens ${ }^{1}$; mas não insistamos demais sobre esta atraente imagem para que o paganismo não volte a levantar a cabeça entre nós. É preferível e suficiente pedir a benção à memória do autor que estudaremos, mas também sem esperar comodamente sua intercessão por um milagre intelectual; basta que este pedido de benção signifique simplesmente um gesto elegante e cortês de humana reverência, antes de começar um texto em que se deve escrever seu nome. Assim, com estes cuidados, de maneira erasmiana, começamos um estudo sobre Erasmo de Rotterdam, mas já imaginando, no entanto, que o mestre reconhecendo-se nestas palavras iniciais e suas familiares precauções, com maior dubiedade, uma mão no peito e um sorriso, declinaria desta homenagem como sempre com um "false accuse..." 2 .

Nesta atmosfera de cuidadoso amor às letras clássicas e de um cristianismo letrado e crítico, abrindo caminhos novos sobre um chão de sentidos escorregadios, escrevendo e corrigindo provas por vezes diretamente sobre rústicas e pesadas prensas, em meio a vasilhames transbordando tinta e trabalhadores que se esbarram, algumas poucas décadas depois da invenção das primeiras tipografias, Erasmo foi o escritor incansável que primeiro alcançou como pensador erudito a formação e o reconhecimento de um verdadeiro público leitor internacional no sentido atual ${ }^{3}$.

\footnotetext{
${ }^{1}$ Horace; Oeuvres complètes - Odes et Épodes, trad. Richard François, Paris, Garnier, $1^{\circ}$ tomo, 1950, pp. 20 e 21. Ode XII do livro I: “Que homem, que herói quer você, Clio, celebrar com a lira ou com a flauta do som penetrante?“ - Quem virum aut heroa Lyra vel acri tibia, sumis celebrare, Clio? ”.

${ }^{2}$ Huizinga, J.; Erasmo, Torino, Giulio Einaudi, 1941, p. 191. De um correspondente, o autor recebe as seguintes linhas: “Já há algum tempo, a modéstia de Erasmo é proverbial. Tem sempre na ponta da língua a frase ‘false accuse’ (...)” ('Afirmas uma inverdade’, i. e., o elogio).

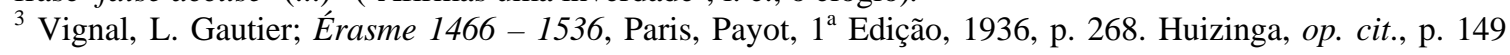
localiza já em 1516 o uso corrente do termo “erasmiano" para indicar a que ponto cresceu a autoridade de Erasmo em toda Europa e na p. 233 informa que na Espanha, por volta de 1528 "eram chamados 'erasmistas' aqueles que tendiam a uma interpretação mais livre da fé”.
} 
Sua obra toda escrita em latim é imensa e integra coleções compostas por 70 c. Colloquia ${ }^{4}, 4.151$ c. comentários de Adagia $^{5}, 3.000$ c. litterae ${ }^{6}$, traduções do grego para o latim e edições - que em grande parte foram edições princeps - de autores como Jerônimo, Cipriano, Hilário, Irineu, Basílio, Ambrósio, Agostinho, Boaventura, João Crisóstomo, Catão, Cícero, Plauto, Amiano Marcelino, Eutrópio, Arnóbio, Sêneca, Aristóteles, Ptolomeu, Josefo, Isócrates, Eurípedes, Demóstenes, Xenofonte, Plutarco e Tito Livio, além do histórico Novum Instrumentum, os 4 livros do Evangelho com a versão grega restaurada, comentada e traduzida para o latim, de um dicionário grego ${ }^{7}$, parafrases, poemas etc.; multiplicidade de escritos que foi pela primeira vez reunida na edição da Opera Omnia em 9 volumes in-folio de 1540 por seu discípulo e amigo Beatus Rhenanus através da casa editora Froben, na Basiléia; trabalho hercúleo ${ }^{8}$ que ocorreu apenas uma segunda e última vez na edição em 10 volumes in-folio entre 1703 e 1706 por Johannes Clericus, hunguenote refugiado em Leiden ${ }^{9}$. A correspondência de Erasmo, já editada no volume III desta última Opera Omnia, foi objeto de minunciosa edição crítica desdobrada em 12 volumes a partir de 1906 por Percy Stafford Allen e sua esposa Helen Mary em Oxford; recentemente, em 1933, W. K. Fergunson publicou um suplemento à Opera Omnia contendo entre outros escritos a Vida de São Jerônimo e o Julius Exclusus, até então ausentes, e desde 1969 em Amsterdã, vem sendo publicada sob o patrocínio da União Acadêmica Internacional e da Academia Real Holandesa de Ciências e Ciências

\footnotetext{
${ }^{4}$ Ménager, Daniel; introdução aos Colóquios em Érasme - Éloge de la Folie, Adages, Colloques, Reflexions sur l'art, l'éducation, la religion, la guerre, la philosophie et correspondence - Édition établie par Claude Blum, André Godin, Jean-Claude Margolin et Daniel Ménager, Paris, Robert Laffont, 1992, p. 214. Esta obra será citada em seguida como “Coletânea R. Laffont”.

${ }^{5}$ Margolin, Jean-Claude, et al in Coletânea R. Laffont, p.103. Vide introdução à seleção de Adágios .

${ }^{6}$ Ménager, Daniel, op. cit., p. 977. Vide introdução à seleção de cartas.

${ }^{7}$ Lins, Ivan; Erasmo, A renascença e o humanismo, Rio de Janeiro, Civilização Brasileira, 1967, p. 215; Halkin, L. E., Erasmo, México D. F., Tezontle, Fondo de Cultura Económica, 1992, p. 88.

8 Huizinga, J.; op. cit., p. 284. "Erasmo costumava de fato comparar o seu trabalho às fadigas de Hércules". Conf. adágio erasmiano 2001 “Herculei labores”.

9 Esta edição da Opera Omnia de Erasmo é conhecida pela sigla LB tirada do nome latino Lugduni Batavorum do lugar de sua primeira impressão em Leiden, atual Holanda. Para as citações de seu Livro dos Antibarbaros - Antibarbarorum Liber - que nesta edição de Opera Omnia integra o volume X, empregarei uma reprodução fotomecânica feita na Alemanha (Hildesheim, editora Georg Olms, 2001) que apresenta duas colunas de texto em cada página e cada coluna com um algarismo arábico sendo que ao longo das colunas há ainda letras maiúsculas de "A" até "F" para indicar posição de frase. Nas citações diretas desta edição dos Antibárbaros apresentarei o nome do autor seguida da sigla internacional que indica a edição de Opera Omnia, neste caso LB, seguida do número do volume em algarismo romano, da coluna em arábico e de uma letra maiúscula referente à sua posição, e. g.: "Desiderii Erasmi, LB, X, 1712 A”.
} 
Humanas $^{10}$, uma nova edição crítica e anotada de toda a obra de Erasmo, edição monumental conhecida por ASD, sigla do nome latino Amstelodami da cidade onde se desenvolvem os trabalhos que poderão exigir 50 volumes ${ }^{11}$. As numerosas publicações internacionais que anualmente tratam da obra do autor são recenseadas e resenhadas atualmente na França pelo professor Jean-Claude Margolin, responsável já pela edição de 3 extensas coleções de bibliografia erasmiana ${ }^{12}$.

Assim, é temerário que alguém interessado na história do pensamento, diante deste oceano de palavras e idéias ${ }^{13}$, se afaste do litoral seguro, onde tantas gerações de comentaristas deixaram suas pegadas e se aventure para ganhar o alto mar discernindo apenas algumas constelações mais facilmente visíveis na movente e nublada paisagem celeste da história da filosofia. Especialmente se, com instrumentos pesados de um trabalho acadêmico, em busca de sistemas de idéias, desenvolvimento orgânico de pensamentos, seqüências de causa e efeito entre conceitos e análise lógica de argumentos, ao tocarmos o tecido liso, a iguaria fresca de um texto concebido por um humanista, nos damos conta subitamente que agimos com o método dos escolásticos, seus concorrentes em prestígio intelectual, repetindo talvez o rigor de Aristóteles que moldou definitivamente nossas universidades, mas perdendo com certeza o brilho da inspiração, o arrebatamento da intuição, a sedução das imagens e o colorido que resulta de um método que não sacrifica

\footnotetext{
${ }^{10}$ Érasme de Rotterdam; La Langue - Introduction, traduction et notations de Jean-Paul Gillet, Genève, Labor et Fides, 2002, p. 11.

${ }^{11}$ Chomarat, Jacques; Érasme - Oeuvres Choisies, Librairie Générale Française, 1991, p. 33. A estimativa de pelo menos de 50 volumes para esta edição ASD pertence ao professor Jean-Claude Margolin e foi expressa em 1992 no prefácio Érasme, notre Contemporain em op. cit., p. II. Já Halkin, op. cit., p.178, previa no início dos trabalhos a necessidade de 40 volumes.

12 Margolin, Jean-Claude; Douze annés de bibliographie érasmienne (1950-1961), Paris, Vrin, 1963; Quatorze annés de bibliographie érasmienne (1936-1949), Paris, Vrin, 1969; Neuf annés de bibliographie érasmienne (1962-1970), Paris e Toronto, Vrin e Toronto University Press, 1977.

${ }^{13}$ Febvre, Lucièn; Au coeur religieux du XVIe siècle, Paris, Librairie Générale Française, 1983, pp. 126 e 127. "Erasmo: ninguém escreveu ainda a história de sua história (...) No caso de Erasmo, eles têm algumas desculpas. A obra, toda latina, é tão vasta; os dez in-folios da edição Le Clerc são tão desencorajantes pela sua amplitude; o homem mesmo cobriu com seu esforço uma tal série de anos, e tão ricas em acontecimentos contrastantes, que se compreende uma espécie de cansaço com a qual tantos gentis espíritos do XVII e do XVIII preferiram um Erasmo na medida de seus pequenos recursos: um Erasmo extraído quase unicamente do Elogio da Loucura ou, no máximo, de seus Colóquios".
} 
tudo pela exclusividade da forma lapidar de uma suposta verdade garantida pela lógica e convive bem com a pluralidade de sentidos desde que favoreça o Homem ${ }^{14}$.

E só esta premonição não basta, pois se Erasmo repetidamente lembra a reserva, a parcimônia e mesmo a isenção cética de Cícero face à profusão de escolas, doutrinas, facções e adversários dogmáticos, mandou gravar em seu timbre pessoal a divisa de honra "Cedo Nulli"15, recusou vários engajamentos vantajosos - inclusive um cardinalato $^{16}$ - se libertou paulatinamente de votos que fizera como jovem padre agostiniano $^{17}$ e do mosteiro a que era vinculado ${ }^{18}$ e nem sequer criou raízes em cidade alguma entre as várias em que viveu, ao contrário, no entanto, ele nunca negou a fé ou desobedeceu à Igreja, sempre se identificou como cristão, com clara tonalidade platônica se esforçou em condensar convicções no que chamou de Philosophia Christi, buscou não só o consenso, mas a verdade nas suas inumeráveis publicações, cartas e polêmicas em que se

\footnotetext{
${ }^{14}$ Utilizarei a grafia "Homem", com maiúscula e sempre no singular, para me referir à categoria humana, destacando de "homem” ou "homens", que se referem aos homens em geral; esta regra não impedirá algumas ambivalências ou opções de estilo, e. g., quando este termo vier em minúsculas contraposto ao termo "Deus", tradicionalmente grafado com a letra inicial maiúscula.

${ }^{15}$ Huizinga, J.; op. cit., p. 283. Na versão italiana, o biógrafo holandês fala de um selo pessoal - sigillo - que Erasmo usava para selar suas cartas que pode ter sido feito em um anel. De fato, Gautier, em op. cit. p. 120, descreve um anel de Erasmo, presente do jovem arcebispo escocês Alexandre Stuart que recebeu como discípulo durante sua célebre viagem à Itália entre 1506 e 1509, e sobre o qual mandou inscrever, no entanto a sentença latina levemente diferente “Concedo nulli”, com o qual selava suas cartas.

${ }^{16}$ Huizinga, J.; op. cit., pp. 267 e 268; Halkin, op. cit., p. 80 e Gautier, op. cit., p. 262.

${ }^{17}$ Érasme de Rotterdam; Éloge de la Folie - Traduction de Pierre de Nolhac, Paris, Garnier, Paris, 1954. Na grande coleção de notas desta edição, p. 285, o tradutor faz o seguinte esclarecimento a propósito dos Augustinenses (na versão latina) citados pelo personagem 'Loucura', p. 130, como religiosos que desejam se singularisar pelo gênero de vida, ambicionando antes se diferenciarem entre si que se parecerem com Cristo: “Agostinianos... Nome dado aos monges mendicantes que seguem a regra de Santo Agostinho e cuja ordem foi na realidade organizada em 1256 pelo Papa Alexandre IV”. Segundo Gautier (op. cit., pp. 18 a 22) Erasmo entrou em 1487 para o convento (monastério) de Emaús em Steyn mantido por uma congregação monástica (ordem) submetida à regra de Santo Agostinho (portanto regular), uma nova congregação de cônegos (canônicos) fundada em Windesheim por Florent Radevijns que já havia participado, no fim do século XIV, da fundação da congregação dos Irmãos da Vida Comum, principal promotora do movimento da Devotio Moderna marcado pela opção por uma religião prática e não especulativa. Carlo Carena na sua introdução ao livro de Erasmo - Il Disprezzo Del Mondo (Silvio Berlusconi Editore, 2000, p. XVI) informa que o convento de Steyn não era muito antigo: “(...) fundado em 1419 sob a regra agostiniana e [na chegada de Erasmo] era dirigido pelo seu quinto Prior; em 1549 já desaparecia devido a um incêndio que o arrasou até o chão”.

${ }^{18}$ Carena, Carlo; op. cit., p. XXIX. Erasmo, mesmo em seu livro O desprezo do Mundo, que parece retomar uma tópica medieval de exaltação da vida contemplativa em um monastério, revela antes um elogio à vida solitária, empregada no estudo intenso, que à vida monacal. O comentador Carlo Carena ainda apresenta um trecho da coleção de cartas de Erasmo em que este precisa [não sem deixar intencionalmente ainda algum grau da inexatitude e oscilação que sempre dará frescor à sua escrita] o sentido desta sua obra $O$ desprezo do Mundo - De contemptu mundi: “[este livro é um] elogio da vida monástica, ou seja, da vida solitária” - Laus vitae monasticae, hoc est solitariae.
} 
envolveu e mesmo, segundo testemunhas, suas últimas palavras antes de morrer foram para um Deus: “Lieve God! ”19.

Também, se para nos assegurarmos diante da profusão das fontes diretas, repetimos em voz alta que o principal e talvez único problema para Erasmo era um só, era o problema ético do indivíduo que deve decidir e agir neste mundo sublunar, que era o mesmo problema urgente colocado pela primeira vez por Sócrates ${ }^{20}$ e que não lhe interessavam absolutamente as especulações metafísicas proporcionados pela lógica ou a distante filosofia da natureza de Aristóteles, o bárbaro ${ }^{21}$ emprego da dialética pela teologia escolástica, o realismo político de seu contemporâneo Maquiavel e outras teorias apressadas em descrever supostas naturezas humanas, o exuberante e por vezes descontrolado espetáculo das artes, o preciosismo literário dos italianos ciceronianos, nem lhe interessava o conhecimento prático das línguas vernáculas, os detalhes dos ofícios, das cerimônias, das regras religiosas de conduta, então, frustrados, ao percorrer com os olhos o catálogo de seus textos, percebemos que a discussão erasmiana sobre os fins, os valores ou o Bem inaugurado por Sócrates extravasa amplamente os temas tradicionais e trata, e. g., do casamento, da superstição, da educação das crianças, da guerra, das regras de etiqueta, da

${ }^{19}$ Huizinga, J.; op. cit., p. 270.

${ }^{20}$ Kristeller, Paul Oskar; El Pensamiento Renascentista y sus fuentes - Compilador Michael Mooney, tradução de Federico Patán López, Madrid, Fondo de Cultura Econômica, 1982. p. 231. Segundo a tradição consagrada por Cícero foi Sócrates que - diferentemente dos pré-socráticos interessados apenas na reflexão sobre problemas da natureza e do pensamento - ao indagar inovadoramente sobre o Homem trouxe a filosofia do céu para a terra. O comentador esclarece que esta sentença foi expressa por Cícero no seu Academica Posteriora em I, 4, 15 e traz mesmo um trecho do original: (Sócrates trouxe os problemas fundamentais do Homem) para o debate cotidiano - a rebus occultis (...) ad vitam communem. No entanto, o exemplo de Lucrécio, que seguindo Epicuro soube extrair de considerações materialistas sobre a natureza também proposições sobre a vida prática tais como a superstição, o medo da morte, a necessidade do ócio etc., deve nos alertar para a possibilidade de que já entre os pré-socráticos ter existido, sem terem sobrevividos, escritos sobre os problemas fundamentais do Homem que Cícero teria naturalmente desconhecido. Rodolfo Mondolfo em Sócrates (tradução de Lycurgo Gomes da Motta, São Paulo, Editora Mestre Jou, 1963, p. 61) articula esta sentença ciceroniana com a prática sofista da época de Sócrates: “A deslocação (sic )da pesquisa do mundo natural para o humano, que já haviam realizado os sofistas por motivos práticos e de utilidade (preparo dos jovens para a vida política), torna a afirmar-se em Sócrates por uma exigência essencialmente teórica e éticoreligiosa: a possibilidade da ciência e o seu papel de purificação espiritual.”

${ }^{21}$ Gilson, Étienne; La Philosophie au Moyen Age - Des origines patristiques à la fin du XIV siècle, Paris, Payot, 1952, p. 727. Erasmo usa em geral o termo "bárbaro” como os humanistas do norte europeu chamam aqueles que desprezam os Studia Humanitatis, desviando intencionalmente do emprego original que os italianos renascentistas faziam deste termo para designar todos os não italianos. Este ufanismo é datado pelo comentador: “ Este tema histórico [os franceses são bárbaros] não datava de Petrarca. Desde o século XI, no seu Líber de vita christiana, o italiano Bonizo tinha livremente usado o termo barbarus toda vez em que queria significar o caráter não civilizado dos povos não italianos”; o registro utilizado por Bonizo era jurídico e político mas “(...) se estendeu com Petrarca ao domínio do saber e exerceu uma influência considerável”. 
emancipação feminina, da pregação, do bom uso da língua etc., mostrando um interesse que inaugura e se irradia por uma desconcertante multiplicidade de novos campos de reflexão.

Se para não nos desesperarmos então entre os milhares de temas que lhe interessaram $^{22}$ nos consolamos com uma abordagem psicologisante buscando explicar a obra pela biografia de uma personalidade peculiar ou com um pouco mais de fôlego insistindo em reduzir ou limitar todas as diferentes discussões do autor à busca particular e prioritária da liberdade intelectual e de expressão e de sua autonomia moral e procurando explicar sua gênese na realidade social em que Erasmo viveu desde a adolescência, i. e., a realidade de um monastério austero, intolerante, ascético e autoritário organizado verticalmente em rígida hierarquia como uma sociedade re-feudalizada em pleno século $\mathrm{XV}$ e na qual recusou a fria e constante coerção dos ritos e regras - que sempre extravam como tirania do gosto e opressão intelectual - ao contrário, continuando a ler seus escritos, ao invés de encontrarmos um escritor revoltado e rebelde, nos deparamos com um intelectual vinculado a um forte sentimento de decoro, respeitoso para com a tradição, crente em uma sabedoria antiga, conhecimento universal, objetivo e essencial que é preciso descobrir, aprender e ensinar, convicto de que o nascimento não faz o Homem mas um ser capaz de receber pela educação a forma humana ${ }^{23}$.

E se em algum momento suspeitamos de um padre agostiniano educado pela Devotio Moderna, que sempre respeitou seus votos, foi íntimo de místicos famosos, doutor em teologia pela universidade de Turin ${ }^{24}$, autor que no seu livro mais famoso, depois

\footnotetext{
22 Cada um dos seus 4.151 c. Adagia corresponde a um comentário a provérbio greco-latino que frequentemente ganha proporções de ensaio de filosofia moral ou política como é o caso de "Dulce bellum inexpertis” - A guerra é doce para aqueles que não a experimentam.

${ }^{23}$ Jacopin, Paul, Lagrée, Jacqueline; Érasme Humanisme et Language - Collection "Philosophies”, Paris, PUF, 1996, p. 23. Os autores insistem que, para Erasmo "A humanidade não é dada com o nascimento; devese adquirí-la. A criança recém nascida tem indiscutivelmente a aparência humana e matéria da humanidade, mas lhe falta sua forma constituída pela racionalidade e pela instrução que a reforça - Os Homens não nascem, são feitos - Homines non nascuntur sed finguntur" (adágio) e que para ele "O nascimento não nos faz Homens mas capazes de receber a natureza humana. Aquele que nasce é uma espécie de matéria bruta; a educação (institutio) aí introduz a forma” (De Conscribendis). Vide também Halkin, op. cit., p. 96: “O homem não nasce Homem, ele se faz” e Margolin no prefácio Érasme, notre Contemporain em Coletânea R. Laffont, p. V: “O homem não nasce Homem. Ele nisso se torna”.

${ }^{24}$ Gautier, em op. cit. p. 89; Margolin et al in Coletânea R. Laffont, tábua cronólogica na p. XXXIV. Vide também Halkin, op. cit., p. 42 e Ivan Lins, op. cit., p. 163.
} 
das críticas ferinas ao seu tempo, glorificou o desprezo paulino da sabedoria do mundo ${ }^{25}$, amigo e correspondente de bispos, cardeais e Papas que, convocado pela Igreja e por fiéis, depois de muito hesitar, desceu à arena a seu favor para enfrentar Lutero, em seguida sorrimos com cumplicidade ao percebermos, ao contrário, mesmo nos escritos doutrinários para a fé, seu distanciamento circunspecto de todo dogmatismo fácil ${ }^{26}$, sua heterodoxia na tradução e exegese bíblica, o silêncio em sua biografia - e mesmo o estranhamento - para com o fervor religioso, o arrebatamento místico e a contemplação inerte, sua crítica ferina ao poder temporal da Igreja, sua riqueza e ostentação, ao ritualismo, aos interesses inconfessáveis do clero e sua conivência com a superstição popular em torno dos santos, relíquias, história de milagres e etc., todas críticas $^{27}$ que lhe valeram a acusação de haver "botado o ovo que Lutero chocou” ${ }^{28}$ e a inclusão de todos os seus escritos no índice da Contra-Reforma em $1559^{29}$.

E se as suspeitas se voltam contra o mestre de retórica - que assim se apresentava $^{30}$ - filólogo e crítico corrosivo de cepa valliana ${ }^{31}$ dos esforços especulativos da teologia através do emprego massivo da dialética e da lógica; crítico da falta de fundamentação do conhecimento apartado das fontes, do barbarismo a que tinha se entregue o latim medieval, da pedagogia empregada no ensino universitário baseado apenas no princípio da autoridade e na selva de manuais impeditivos do contato direto com os clássicos; se olhamos com desconfiança para o escritor indiferente à profunda especulação

25 Érasme de Rotterdam; Éloge de la Folie, Tradução de Pierre de Nolhac, op. cit., p. 170. Dos 68 capítulos desta edição, em que autor através da personagem “Loucura” elogia os homens por serem seus discípulos, já próximo da conclusão, no capítulo LXV se levantará a potente inflexão que revela que a maior merecedora de elogios é a religião cristã, para a qual, segundo seu apóstolo S. Paulo, Deus quis salvar o mundo pela loucura - Deo Visum est, ut per stultitiam servaret mundum (...) a loucura [da morte] na cruz - per stultitiam crucis.

${ }^{26}$ Érasme de Rotterdam; L'essai sur le libre arbitre, Tradução de Pierre Mesnard em Érasme - La Philosophie Chrétienne, Paris, Vrin, 1970.

${ }^{27}$ De Bujanda, J. M; introdução a Érasme de Rotterdam - Liberté et Unité dans l'Église, Quebec, Editions Cosmos, 1971, p. 17. A independência crítica de Erasmo merece este comentário: "Ele [Erasmo] falará sempre deste estado de suspeição [que o cerca] que ele traduz por ele mesmo por uma frase bem conhecida: 'Sou um gibelino para os guelfos e um guelfo para os gibelinos”.

${ }^{28}$ Gautier, op. cit., p. 238. "Apesar dos elogios que certos católicos lhe derramavam, ele era sempre acusado de ter sido luterano antes de Lutero e de ter botado o ovo que o outro chocou”.

${ }^{29}$ Godin, André, Introdução in Coletânea R. Laffont, p. 551.

30 “Ego rhetor”, vide verbete “Rhétorique” p. CCXVIII do dicionário incluído in Coletânea R. Laffont. Erasmo também se apresentava, mais modestamente como 'Rhetorculus' como nos informa John P. Dolan em The Essential Erasmus - selected and translated with introduction and commmentary, New York, Meridian Book, 1993, p. 13.

${ }^{31}$ D’Ascia, Luca; prefácio L'ombra de Valla - La formazione “laica” de um genio religioso del Cinquecento à sua tradução do livro de Erasmo Antibarbari, Torino, Nino Aragno Editore, 2002. 
teórica de Agostinho, ao rigor dos argumentos ainda realistas de Tomás de Aquino; para o amante confesso da literatura e da poesia entregue à leitura onívora dos clássicos gregos e latinos que preferiu os textos alegóricos, a linguagem figurada dos Padres da Igreja primitiva e a exegese imaginativa; para o homem das letras, prosista fantasioso ${ }^{32}$ e tradutor sobretudo de Luciano, Horácio, Ovídio e Terêncio ${ }^{33}$; para o poeta amador que desconheceu a noção de progresso da ciência inventiva e cumulativa; ao contrário, no entanto, ficamos desnorteados com a lúcida e dura crítica que fez aos imitadores servis de Cícero ${ }^{34}$ e sua defesa intransigente da simplicidade, e até rusticidade, de uma linguagem própria para a expressão de uma verdade cristã ${ }^{35}$, com o combate teórico que levou à multiplicação das escolas filosóficas ${ }^{36}$ e suas aporias e com sua surpreendente pregação por um falar e

\footnotetext{
${ }^{32}$ Lutero, M.; De servo Arbitrio, em Obras de Martin Lutero - la voluntad determinada, tradução castelhana de Erich sexauer, Buenos Aires, Publicaciones El Escudo e Paidós, 1976, p. 39. O talento de escritor de Erasmo mereceu uma amarga crítica de Lutero: “Que necessidade tem de transbordar em palavras?”.

${ }^{33}$ Halkin, op. cit., p. 88.

${ }^{34}$ Carena, Carlo; prefácio a Erasmo da Rotterdam - Il lamento della Pace, Giulio Einaudi, Torino, 1999, p. 17. "O Ciceronianus (1528), entre caricaturas, leva uma crítica cortante com erudição soberana aos classicistas petulantes, nostálgicos do paganismo, do belo estilo, mas de palavras vazias e hostis à linguagem moderna e à literatura cristã; a repulsa ao purismo embalsamado estimula Erasmo a uma critica revisionista do seu próprio humanismo, sujeito a tais deformações, submetendo-o a uma exigência moral ou mesmo religiosa que com os anos crescia em sua consciência".

${ }^{35}$ Erasmo de Rotterdam; Le cicéronien (Dialogus ciceronianus), extratos da obra incluídos in Coletânea R. Laffont, p. 427.

${ }^{36}$ Érasme de Rotterdam; Éloge de la Folie, op. cit., pp. 118 e 119. É inesquecível a acidez com que a personificação da 'Loucura' afirma: 'E estas sutilíssimas sutilezas tornam ainda mais sutil os caminhos [do pensamento] dos escolásticos - Jam has subtilissimas subtilitates subtiliores etiam reddunt tot scholasticorum viae - a tal ponto que você se livra mais rapidamente de um labirinto - ut citius e labyrinthis temet expliques - que destes embrulhos cheios de laços - quam ex involucris - dos realistas, nominalistas, tomistas, albertistas, ocamistas e escotistas - Realium, Nominalium, Thomistarum, Albertistarum, Occanistarum, scotistarum - e ainda não disse todas as seitas, mas apenas as principais - et nondum omneis dixi [sectas], sed praecipuas duntaxat. A tradução francesa propõe: "Des subtilités plus subtiles encore encombrent les voies où vous conduisent les innombrables scolastiques. Le tracé d'un labyrinthe est moins compliqué que les tortueux détours des réalistes (...) et tant d'écoles dont je ne nomme que les principales”. Também no seu Antibarbarorum Líber (LB, 1711 F e 1712 A), Erasmo repete contra os bárbaros a mesma carga a respeito da multiplicação das facções: "Você invoca para si estas denominações bárbaras - Tu tibi barbaras istas appellationes adssciscas - e se diverte em chamar-se albertista, tomista, escotista, ocamista ou durandista teque vel Albertistam, vel Thomistam, vel scotistam, vel Occanistam, vel Durandistam vocari gaudeas - como se fossem equivalentes mesmo do nome de Cristão - dummodo à Christianis denomineris". A versão italiana de Luca D`Ascia em Antibarbari op. cit., p. 134, prefere: "Tu te li andresti pure a cercare, questi tuoi barbari appellativi, e ti compiaceresti di passare per 'Albertista' (...) ti basta sapere che tutti costoro furono cristiani".
} 
escrever inspirados na linguagem divina que é sempre rara, breve, perfeitamente verdadeira e eficaz ${ }^{37}$.

Além, do volume, as ambivalências e tortuosidades que cercam a obra e seu autor, há ainda a incompreensão geral sobre o movimento cultural criado pelos humanistas ao qual o nome de Erasmo está definitivamente associado e a tal ponto identificado que lhe é atribuído por vezes o título de "Príncipe dos Humanistas", honrosa deferência que pode encobrir um duplo equívoco que ora toma os humanistas precipitadamente como representantes de uma específica escola filosófica, ora os despacham como literatos e poetas diletantes, simples entusiastas do classicismo, descomprometidos com qualquer desvelamento da verdade ou criação de sentido no quadro da tradição filosófica.

E esta incompreensão geral sobre o correto caráter do humanismo se associa ainda à relativa novidade entre nós dos estudos renascentistas face à longa tradição, e. g., dos estudos de filosofia antiga e medieval. A juventude neste caso traz apenas problemas: o período do Renascimento é visto em geral apenas como fase preparatória para as seguintes; seus escritores tomados por epígonos e não como pensadores de sua própria época; os estudiosos deste período lêem e dispõem de pouca literatura primária e mesmo segundária; supervalorizam assim o papel de figuras notórias, pois extravagantes, e perdem a continuidade de questões centrais; ignoram, e. g., o que significou o misticismo, a astrologia e a magia, exageram a grande influência do aristotelismo; confundem a tradição filosófica retórica com a eloqüência e suas regras formais; focam sempre o mesmo grupo excêntrico de pensadores renascentistas tais como Leonardo da Vinci, Paracelsus, Nicolau de Cusa, Telesio, Campanella etc. e esnobam quem foi reconhecido já em seu próprio tempo; omitem o que foi vital e lhes escapa e concentram-se sobre o que não era essencial para a filosofia do período, além de toda a ordem de anacronismos ${ }^{38}$.

\footnotetext{
${ }^{37}$ Érasme de Rotterdam, La Langue, op. cit., p. 171. Mesmo escrevendo prodigiosamente, o autor é capaz de advertir sem receio: "Futilidade e vanitude são ligadas, como disse, à loquacidade. Ora, se é verdade que Deus fala muito raramente, fala brevemente e suas palavras são ao mesmo tempo perfeitamente verdadeiras e perfeitamente eficazes”.

${ }^{38}$ The Cambridge History of Renaissance Philosophy - Edited by Charles B. Schmitt and Quentin Skinner, Cambridge University Press, 1996, pp. 1 a 4.
} 
E por último, ainda temos a barreira da língua, pois se diante da muralha de palavras de um latim precioso - muralha toda amarrada por uma gramática ágil e vivaz do século XVI que, medindo-se e rivalizando com a do período clássico, ama o elegante e caprichoso virtuosismo - esfregamos as mãos e, pragmáticos como os romanos, saímos apressados pelos campos à caça de traduções para empregá-las como aríetes, máquinas de guerra e escadas - arietum et macchinam bellica scalaeque - então, surpresos, descobrimos em geral no Brasil apenas edições secas e tímidas do Elogio da Loucura e estarrecidos, confirmamos pela Internet que a maior parte da obra erasmiana ainda dorme no latim original, delícia reservada apenas para especialistas.

Mas, somos realmente chacoalhados ao compreendermos que - em contraste com o atual e constante avanço da tecnologia que nos torna entusiastas e faz acreditar que há um frenético progresso geral das coisas humanas - a capacidade de invenção humana - inventio - para pensar o próprio Homem e suas questões fundamentais é finita, limitada, irrepetível e encontra com grande esforço e sem garantias de demonstração exata o que é novo e ao nos darmos conta de que algumas invenções da cultura são insuperáveis, que algumas soluções para aquelas questões fundamentais são conquistas definitivas, que algumas interpretações da realidade humana são perenes, inesquecíveis e incontornáveis em qualquer discussão e o que é preciso, então, não é exatamente "progredir", mas distribuir melhor este conhecimento já acabado do homem sobre si mesmo para todos os excluídos deste banquete. Depois de compreendermos isto, sofremos uma dor quase física ao nos darmos conta de que a filosofia, enquanto tradição retórica que reuniu estes achados desde o surgimento ou chegada da escrita no Ocidente, foi quase toda perdida pelo tempo - o cruel Chronos devorador de seus próprios filhos.

Após percebermos o valor destas invenções em termos de qualidade e sua raridade em termos de quantidade, constatando boquiabertos que realmente nossas bibliotecas não fazem mais que acolher livros que, afora exceções geniais, apenas repetem e tentam desdobrar, explicar o que já está implicado - complicatio - nas raras sobras destas ruínas antigas em forma de textos retóricos, passamos subitamente a venerar as imagens literárias e mesmo as palavras em que estas invenções foram com mais probabilidade 
concebidas, cientes que são poucas e insubstituíveis, vendo agora as traduções e especulações posteriores apenas como cascalhos que encombrem o brilho do que é original e único, e por isto preferível; brilho do que corresponde melhor ao que chamaríamos sem medo de "realidade humana a mais profunda" simplesmente porque retrocede na história do pensamento discursivo até onde é materiamente possível, i. e., junto à enorme parede de silêncio que é o mundo da pré-escrita. Mas vamos descobrindo isto tardia e individualmente, estudando as línguas clássicas na medida que apreendemos sua verdadeira e secreta importância, fazendo sozinhos o que a sociedade não pôde nos oferecer na juventude sob a forma de um sólido ensino público das matérias hoje chamadas com algum desdém de "humanidades".

Frente a todas estas dificuldades, no entanto, olhando para as flores deste amplo jardim erasmiano, cultivado e percorrido por estreitas e tortuosas alamedas, acreditamos poder colher ao menos um único pensamento para uma modesta discussão filosófica, mas um pensamento que parece ser crucial simultaneamente para a história das idéias, para o humanismo e a filosofia renascentista, para a história das religiões e mesmo para a compreensão do percurso e importância intelectual de Erasmo: a unidade da verdade. Pensamento de aparente inspiração platônica, conviç̧ão típica dos intelectuais renascentistas $^{39}$, mas articulado, exercitado e aplicado pelo autor na realização de seu grande projeto pessoal que foi aquele do esforço intelectual inusitado, definitivo e aguardado desde Petrarca, no início da Renascença, para a compatibilização e conciliação teórica ponto a ponto entre a doutrina cristã e as ciências, as disciplinas pagãs; entre o

\footnotetext{
${ }^{39}$ D’Ascia, Luca; op. cit., pp. 42 e 43. Veja-se o caso da publicação de "Vallum humanitatis" entre 1518 e 1520 pelo humanista da Westfalia Hermann Von dem Busch e da “Epistola in pseudodialecticos” em 1520 pelo literato e humanista valenciano Juan Luis Vives, todos livros que procuram mostrar a convergência entre o programa humanístico de estudos, sua nova metodologia, e a doutrina cristã e hostilizar os escolásticos.
} 
cristianismo e a sabedoria, a literatura, a erudição secular, as letras humanas ${ }^{40}$, ou mais humanas - Humaniores litterae; entre a religião cristã e a tradição retórica da filosofia começada pelos gregos; entre fé e saber; assim como outros pensadores renascentistas reinstauravam suas áreas, e. g., a arquitetura, botânica, farmacologia, gramática, direito etc., recuperando sua herança clássica.

Então, da pluralidade de escritos de Erasmo nos pareceu prioritário o estudo do primeiro livro iniciado pelo autor, preparado e corrigido durante décadas de reflexão e publicado apenas em 1520; livro que foi dedicado exclusivamente à defesa das letras humanas: o Livro dos Antibárbaros - Antibarbarorum Liber - e em especial, de seus últimos e decisivos 32 argumentos. Livro que o autor escolheu de próprio punho em seu testamento como o primeiro livro da primeira ordem para a edição de sua Opera Omnia ${ }^{41}$.

No entanto, antes da consulta à fonte direta - Ad fontes - bordão a propósito inventado pelos humanistas, propomos primeiramente no Capítulo I a visita

\footnotetext{
${ }^{40}$ Kumaniecki, Kazimierz, introdução ao Antibarbarorum Líber - Ordinis Primi, Tomus Primvs, in Desiderii Erasmi Roterodami - Opera Omnia - Recognita et adnotatione critica instrvcta notisque illvstrata, ed. Kazimierz Kumaniecki, Amsterdã, North-Holland Publishing Company Amsterdam, 1969, p. 23. “A literatura clássica que Erasmo está defendendo [nos Antibárbaros] também sofre uma mudança de nomes; na primeira versão [manuscrita em Halsteren entre 1494 ou 1495, localizada por P. S. Allen na biblioteca municipal de Gouda e publicado por Albert Hyma em The Youth of Erasmus, Ann Arbor, 1930] ele com mais freqüência fala de "litterae seculares" ou "Iiteratura gentilis"; na segunda versão [que é a primeira edição impressa por Froben, na Basiléia em 1520] o adjetivo "seculares” é trocado por "bonae", "humanae”, "liberales" ou “elegantiores", "politiores” ou "profanae”. No último período de Erasmo, "secularis” é o adjetivo que os inimigos da literatura usam para esta, talvez este seja o motivo pelo qual o descartou e introduziu outras definições. Em geral, ele tenta remover o adjetivo "gentilis" da segunda versão trocando-o com o sinônimo "ethnicus" ou "prophanus" que considerava mais elegantes”. Esta introdução ao Antibarbarorum Líber integra a monumental edição crítica e anotada, ainda em andamento, da Opera Omnia de Erasmo, a terceira depois daquelas de 1540 editada na Basiléia por Johann Froben e de 1703 em Leiden por Jean Leclerc, que é conhecida internacionalmente pela sigla ASD do nome latino Amstelodami da cidade onde se desenvolvem os trabalhos; esta edição será sempre citada como "Desiderii Erasmi, ASD".

${ }^{41}$ Desiderii Erasmi, ASD, Ordinis Primi, Tomus Primvs, pp. I a XVII. Na extensa introdução geral, é informado que o autor já em uma carta para Johann Botzheim em 1523 e outra para Hector Boece em 1530 apresenta seu plano de publicação - Index Lucubrationum - de toda a sua obra não em seqüência cronológica, mas temática, como segue: 1 Ordem de livros que tratam do ensino das letras - Ordo Librorum qui spectant ad institutionem literarum; 2 Adágios - Adagia; 3 Cartas - Epistolarum; 4 Escritos morais - Ordo quartus moralia continens; 5 Escritos Teológicos - Ordo quintus pertinentium ad pietatem; 6 Novo Testamento anotado - Annotationes; 7 Parafrases, 8 Traduções de São Crisóstomo, Atanásio, Orígenes e Basílio, 9 Apologias - Apologiae. Este cânon foi obedecido zelosamente pela edição Froben para a qual colaborou o fiel amigo Beatus Rhenanus, pela edição Leclerc que explicita esta medida também no seu prefácio geral sequuti igitur sumus Editionem Frobenianam (...) - e igualmente por esta recente edição de Amsterdã, como se lê na introdução geral - It was decided that, like its predecessors, it was to be arranged according to the canon laid down by Erasmus in his letters to Botzheim and Boece.
} 
crítica a partir de Étienne Gilson ${ }^{42}$ aos comentadores Werner Jaeger ${ }^{43}$ e Paul Oskar Kristeller $^{44}$ como representantes da diferenciação, amplificada pelo senso comum e mesmo acadêmica, entre filósofos renascentistas “profissionais” e pensadores humanistas. Esta crítica é incontornável para se restaurar a unidade entre filosofia e retórica como unidade preliminar que possibilita por sua vez a correta compreensão dos recursos intelectuais empregados pelo esforço erasmiano em prol da unidade da verdade. No Capítulo II se buscará a reconstituição da urgência do problema da unidade da verdade na Renascença com apoio das lições de Kristeller, Richard H. Popkin ${ }^{45}$, Sérgio Cardoso ${ }^{46}$, Carlo Colombero $^{47}$ e Ernest Cassirer ${ }^{48}$, para a leitura de trechos pontuais da obra de Agostinho, Lutero e Montaigne em comparação com o tratamento que a obra de Erasmo dá a esta questão; já para a aproximação desta particular colaboração erasmiana para com a história do pensamento, serão considerados os trabalhos de especialistas tais como Luca D’Ascia ${ }^{49}$, Jean-Claude Margolin ${ }^{50}$, Paul Jacopin e Jacqueline Lagrée ${ }^{51}$ e Francisco Rico ${ }^{52}$. No Capítulo III Lucièn Febvre ${ }^{53}$, Erwin Panofsky ${ }^{54}$ e Maria das Graças de Souza ${ }^{55}$ serão importantes para o estudo de noções vinculadas de liberdade e historia em Erasmo e aqueles especialistas passarão a auxiliar também na apresentação, contextualização e exploração interpretativa direta do Antibarbarorum Liber como resposta erasmiana à crescente crise da unidade da verdade que acaba por eclodir, no entanto, com a Reforma. Finalmente, no Capítulo IV, se pretende a análise e síntese dos 32 últimos argumentos identificados no coração desta obra em sua versão original latina editada entre 1703 e 1706

\footnotetext{
${ }^{42}$ Gilson, Étienne; Philosophie au Moyen Age - Des origines patristiques a la fin du XIV siècle, op. cit..

43 Jaeger, Werner; Paidéia - A formação do Homem grego, São Paulo, Martins Fontes / Universidade de Brasília, 1989.

${ }^{44}$ Kristeller, P. O.; El Pensamiento Renascentista y sus fuentes, op. cit.

${ }^{45}$ Popkin, Richard H. ; Histoire du Scepticisme d'Érasme a Spinoza - Traduction de Christine Hivet, Paris, Presse Universitaires de France, 1995.

${ }^{46}$ Cardoso, Sérgio; “O Homem, um Homem: do Humanismo renascentista a Michel de Montaigne” in Coletânea Imago.

${ }^{47}$ Colombero, Carlo; Uomo e natura nella filosofia del Rinascimento, Torino, Loescher, 1985.

${ }^{48}$ Cassirer, E., Kristeller, P. O e Randall Jr.; The Renaissance Philosophy of Man, Chicago, The University of Chicago, 1948.

${ }^{49}$ D’Ascia, Luca; no prefácio citado.

${ }^{50}$ Margolin, Jean-Claude, Érasme, in Coletânea R. Laffon.

${ }^{51}$ Jacopin, Paul, Lagrée, Jacqueline; Érasme Humanisme et Language, op. cit.

${ }^{52}$ Rico, Francisco, Il sogno dell'umanesimo - da Petrarca a Erasmo, Torino, Giulio Einaudi, 1998.

${ }^{53}$ Febvre, Lucièn, Au coeur religieux du XVIe siècle, op. cit.

${ }^{54}$ Panofsky, Erwin, Renascimento e Renascimentos na Arte Ocidental, Porto, Editorial Presença, 1981.

${ }^{55}$ Souza, Maria das Graças de; Ilustração e História - o pensamento sobre a história no iluminismo francês, São Paulo, Discurso Editorial, 2001.
} 
com o apoio da tradução italiana de Luca D’Ascia ${ }^{56}$, única alternativa localizada. Este percurso proposto pode nos esclarecer sobre o recurso empregado e o problema teórico enfrentado pelo autor antes de propriamente estudarmos sua resposta, hoje, ao que parece, tão pouco lembrada quanto silenciosamente assimilada pelo senso comum.

${ }^{56}$ Erasmo da Rotterdam, Antibarbari - a cura di Luca D’Ascia, Torino, Nino Aragno Editore, 2002. 


\section{CAPITULO I}

\section{FILOSOFIA E RETÓRICA EM ERASMO}

É preciso antes de tudo restaurar a unidade entre filosofia e retórica que nos dias de hoje parece perdida. É preciso superar uma falsa e comum diferenciação entre filosofia e retórica e recuperar um primordial sentido único, sentido sem o qual não se torna compreensível como, depois que o escolasticismo - contrariamente à sua ambição teorizante - fracassou em impedir que a tensão entre fé e razão chegasse ao seu esgarçamento, foi possível a Erasmo responder no início do século XVI a um então longo, crescente e angustiante anseio de toda a inteligência da Renascença e tratar da verdade comum ao cristianismo, à Bíblia, à Revelação cristã e à erudição clássica, às disciplinas profanas, à sabedoria antiga, i. e., tratar da unidade da verdade ${ }^{57}$.

É estabelecido que a reflexão sobre a relação entre Ser e pensamento começada pelos gregos pré-socráticos e fixada em seus dois cânones concorrentes por Platão e Aristóteles - atravessa os séculos sob o nome de "metafísica”,58 na bacia do Mediterrâneo, alcança em várias ondas a Europa ocidental e medieval até ser

\footnotetext{
${ }^{57}$ Mondolfo, Rodolfo, op. cit., p. 62. A unidade da verdade é normalmente associada ao mundo das idéias de Platão onde as idéias são originais, eternas e únicas. Mas o comentador lembra uma lição de Aristóteles “[Sócrates] nas coisas morais procurava o universal, pois foi o primeiro que tomou como objeto de seu pensamento as definições (...) Tinha razão em procurar as essências (o que é cada coisa) pois queria raciocinar, e o princípio dos raciocínios é constituido pela essência das coisas”, e o comentador explica: a essência, o universal, quer dizer, o que há de comum nas particularidades, representa a unidade da espécie: por isso, afirma-se vigorosamente em Sócrates a exigência de unidade no conhecimento verdadeiro.”

${ }^{58}$ Lohr, Charles H., artigo "Metaphysics" in The Cambridge History of Renaissance Philosophy, op. cit., p. 537. “A matéria disciplinar metafísica tem sido debatida desde o tempo em que Aristóteles pela primeira vez concebeu a idéia de ciência. Ele próprio fala da ‘ciência que nós estamos procurando' e a descreve diferentemente em diferentes lugares. Na Metafísica IV ('1003a21-6) ele fala da ciência que estuda o Ser como Ser e contrasta esta ciência com as ciências especiais como as disciplinas matemáticas que investigam os atributos de uma parte do Ser. Dois capítulos depois, IV.3 (1005b-2) Aristóteles fala da ciência que ele chama de 'primeira filosofia' pois funda os primeiros princípios ou axiomas das ciências especiais. Mas no livro VI.1 (1026a18-19) ele distingue três tipos de ciência especulativa, a física, a matemática e a 'ciência divina',"
} 
completamente absorvida e aprofundada ${ }^{59}$ pelos escolásticos do século XIII, funda as ciências e inspira a concepção de grandes sistemas filosóficos da era moderna e se mantém entre nós sob o nome de “ontologia”; mas esta longa e fundamental reflexão não pode pretender usurpar ou monopolizar nas nossas universidades todo o significado da Filosofia.

Esta imprecisão, que não pertence apenas ao senso comum, é compreensível, pois se já na inauguração entre nós da história da cultura - a kulturgeschichte - Jacob Burckhardt em sua obra monumental de 1860 passava sob silêncio a filosofia na Renascença, os esforços pioneiros que então se seguiram para reconstituí-la e resgatá-la no final do século $\mathrm{XIX}^{60}$ também não foram capazes de tornar claro e amplamente conhecido que, neste período, o pensamento filosófico continua e leva ao completo florescimento sua legítima tradição retórica, i. e., a tradição da filosofia como retórica que é reflexão sobre os problemas fundamentais do Homem e seu Sumo Bem.

Assim é necessária e imprescindível, antes de tudo, a visita crítica a dois conhecidos comentadores para se localizar com alguma exatidão os preconceitos, posturas, equívocos e julgamentos atuais que, mesmo no meio acadêmico, podem impedir a

${ }^{59}$ Gilson, Étienne; op. cit., pp. 540 e 541. Para o comentador, Tomás de Aquino supera Aristóteles, pois “O Deus de São Tomás não é o Ato puro do pensamento que presidia o mundo de Aristóteles, mas o Ato puro de existir que criou do nada o mundo cristão dos indivíduos atualmente existentes; cada um como estrutura complexa de potência e ato, de substância, de faculdades e de operações diversas, tira sua unidade do ato próprio de existir pelo qual ele é tudo isto junto, e que derivando deste ato existencial o poder de operar, trabalha sem cessar para se aperfeiçoar segundo a lei de sua existência, em um incessante esforço para se reunir à sua causa primeira que é Deus. Ultrapassando assim o aristotelismo, São Tomás introduzia na história uma filosofia (...)”. Em outra passagem na p. 590, o comentador esclarece: "São Tomás toma em um sentido novo a fórmula clássica 'essentia est id cujus actus est esse'. $\mathrm{O}$ ato da essência [i. e., o ato de ser] não é mais desta vez a forma, quo est [pelo que é] do quod est [do que é] que ela é, mas a própria existência. O Ser não é mais simplesmente 'aquilo que' é que se entende no sentido de Platão ou de Aristóteles, ele é aquilo que 'é ‘. Em resumo, para retomar uma fórmula familiar a São Tomás, ens significa esse habens, desde Deus, ato puro de existir, cuja operação propria é o ato de criar os atos de existir, do qual cada um se explicita por sua vez em operações próprias (operatio sequitur ESSE) a fim de realizar tanto quanto possível suas virtualidades (...) Muitos dos contemporâneos de São Tomás sentiram que sua doutrina era nova (...)”.

${ }^{60}$ The Cambridge History of Renaissance Philosophy, op. cit., p. 1. De fato, os estudos sobre a filosofia na Renascença são muito recentes e esta coletânea de textos sobre o período, editada por Cambridge, é obrigada a confessá-lo já na sua primeira página: até o século XIX a tradição acadêmica anglo-saxã tratava os dois séculos que seguiram a morte de William Ockham apenas como um período preparatório para a era "heróica" de Francis Bacon e sua "nova filosofia” e pensadores tais como Ficino, Bruno e Campanella foram estudados por historiadores basicamente interessados em traçar as raízes do pensamento "moderno". Este quadro mudou final do século XIX com os trabalhos de Renan, Mabilleau, Fiorentino, Tocco, Amabile entre outros, mas a importante inflexão foi feita apenas no primeiro quarto do século XX quando os esforços de dois acadêmicos deram uma definição mais clara da fisionomia da Renascença; estes são Giovanni Gentile e Ernest Cassirer. 
compreensão, a restauração do sentido único que havia para o autor entre filosofia e retórica; unidade preliminar cuja consideração nos parece imprescindível para um melhor estudo da unidade da verdade em Erasmo.

Werner Jaeger é um modelo de erudito cujas obras têm amplo alcance no meio universitário brasileiro e cujas opiniões merecem sempre ser consideradas e ponderadas, mas no seu livro mais famoso entre nós, Paidéia - a formação do Homem grego, ampla e detalhada avaliação da cultura grega sob visível inspiração hegeliana, há a fixação de uma certa compreensão da história da filosofia antiga que implica em conseqüências para o estudo do Renascimento como é o caso quando este comentador apresenta Platão, por meio de seu personagem “Sócrates”, como representante da filosofia compreendida como busca do conhecimento da verdade, o que para os assuntos humanos equivale ao conhecimento de seu Sumo Bem, em oposição aos sofistas, entre eles especialmente Isócrates, que serão apresentados como representantes da tradição retórica, interessada apenas na opinião acertada para as questões práticas.

Esta oposição contrastante entre filosofia e retórica, segundo Jaeger, se deve ao fato de que a retórica não resiste ao ataque da dialética, pois padece de um vício fundamental: ela não possui nenhuma filosofia, é puro meio sem finalidade que entregue ao homem não exercitado na dialética, torna-se instrumento para a obtenção do que este pensa espontaneamente ser o melhor para si, que é o poder do tirano, e que, no entanto, será a simples aceitação da vida como luta e agressão e sancionamento da violência ${ }^{61}$. Ao contrário, o conhecimento que pode discernir o bom do mau entre as possibilidades da experiência humana é o conhecimento dos valores supremos além da mera aparência, opinião e dos sentimentos subjetivos, é o seguro conhecimento do Bem, a finalidade e objetivo, o telos, no qual se realiza e se alcança a perfeição, a essência do Homem, do seu próprio cosmos. Diferentemente do método sofístico de imposição vertical, quase mecânica, de um saber enciclopédico em um processo de assimilação passiva, a dialética é uma procura esforçada em um processo de abstração crescente que parece tirar o saber da própria inteligência de indagadores participantes guiados por alguém experiente no método,

${ }^{61}$ Jaeger, Werner, op. cit., pp. 451 a 453 
mas nem sempre detentor das respostas completas como o personagem "Sócrates" que afirma sempre de maneira dúbia o seu não saber. ${ }^{62}$

A partir desta oposição entre filosofia e retórica, Jaeger afirma que é Isócrates o mais destacado representante da retórica que vindo a coroar o movimento da cultura sofística se levantará contra as exigências de Platão e do círculo socrático ${ }^{63}$ e personificará a antítese clássica ao que Platão significa com seus escritos. A partir de então ressoaria o pleito da filosofia e da retórica que se torna então um autêntico duelo nos séculos seguintes, cada uma da quais pretendendo ser a melhor forma de educação. Os problemas com esta interpretação, no entanto, já começarão a surgir quando é necessário reconhecer que na prática, a educação sofístico-retórica continuou a viver sem diminuição da sua força - e mesmo se instalou definitivamente entre os gregos - e que, quanto à nomenclatura, Isócrates dava o nome de “filosofia” ao objetivo que visava que era a formação geral do espírito classificando, como a linguagem de seu tempo fazia, de "sofística” a cultura de aspecto mais teórico, como a de Sócrates e de seus discípulos, usando de maneira invertida o sentido atual da palavra "filosofia” que é justamente o platônico $^{64}$.

Outro problema provocado por esta oposição, que o comentador estabelece entre filosofia e retórica está na necessidade de apresentar Isócrates como um pensador que salienta a importância da cultura geral em oposição a um determinado dogma ou método de conhecimento tal como os platônicos o exigiam ${ }^{65}$ e que acusa Sócrates de se tornar, com suas contínuas perguntas e indagações, um investigador do reino da moral, mas chegar por fim à porta fechada de um novo saber ${ }^{66}$. Ora, buscando contrastes e pensando os retóricos como pensadores comprometidos apenas com o sucesso político afastados da busca da verdade, resta ao comentador a compreensão de um Sócrates propositor

\footnotetext{
62 Idem, p. 488.

63 Idem, p. 729.

${ }^{64}$ Nesta passagem começam as dificuldades da proposta metodológica do comentador: sua separação entre filosofia, que vincula à metafísica, e a retórica, que vincula ao estudo da eloqüência e aos sofistas, não é confirmada por vários textos que, na realidade afirmam o contrário chamando Sócrates de "sofista”, vide As Nuvens de Sófocles, e os discípulos de Isócrates como “filósofos” como no caso de Cícero.

65 Jaeger, Werner, op. cit., p. 730.

66 Idem, p. 732.
} 
dogmático da teoria das idéias platônicas em tensão com o personagem platônico “Sócrates” visto antes como indagador e, segundo muitos, o próprio fundador do ceticismo com a afirmação de que "Tudo que sei é que nada sei”. 67

Outra dificuldade está no reconhecimento obrigatório para Jaeger de que Isócrates torna-se grande ao propor uma retórica purificada do ensino amoral a que estava entregue - visando apenas interesses políticos pessoais mesquinhos - como única paidéia verdadeiramente capaz de melhorar a vida política; e que o retórico pensa para a sua arte um novo objetivo, um pathos mais elevado, uma finalidade maior que é o pan-helenismo, a união dos gregos em uma igualdade entre vencedores e vencidos, o entendimento em um grande empreendimento comum para o qual deverão se agrupar os Estados gregos como única solução para se evitar a desintegração da Grécia e com ela a ruína de suas partes ${ }^{68}$.

Ora, este reconhecimento dos méritos da retórica leva o comentador a um paradoxo: sua metodologia o obriga a não aceitar a retórica como filosofia e então toda a elevada ciência ético-política proposta e sustentada teoricamente por Isócrates, um pensador confiante em que a educação superior se baseia no desenvolvimento da capacidade de mútua compreensão entre os homens e convicto da possibilidade prática de um conhecimento advindo da história. Então, para Jaeger, deve ser excluida do conceito de filosofia e com ela toda a filosofia política seguinte constituinte da tradição retórica, por maiores que tenham sido suas conquistas para o pensamento ${ }^{69}$. E é uma estratégia precária sustentar que Isócrates alcança uma solução média entre o sublime da teoria e a técnica rotineira da política freqüentemente reduzida às finalidades contrárias à moral; um meio termo entre a indiferença moral da retórica puramente sofística anterior e o critério platônico que consiste em reduzir a política à ética e que, praticamente, volta as costas à

\footnotetext{
${ }^{67}$ Mondolfo, Rodolfo; op. cit., p. 100. “A expansão da influência de Sócrates começa durante a sua vida, porém intensifica-se depois da sua morte. Toda a filosofia grega posterior está dominada por seu influxo; os seus discípulos ocupam com suas escolas a época imediatamente subseqüente: (...) os neo-acadêmicos Arquesilaus e Carneádes proclamam a exigência de um retorno a Sócrates.”

68 Jaeger, Werner, op. cit., p. 733.

$69 \mathrm{Na}$ Renascença, o estudo da história através dos textos retóricos que trazem os exemplos, as gestae - que constituirão uma das disciplinas dos Studia Humanitatis, serão ocasião de incipientes filosofias da história e mesmo do nascimento da moderna filosofia política com Maquiavel - não seria portanto, para Jaeger classificável como filosofia; parece que esta lição será assimilada por P. O. Kristeller nos seus estudos sobre o período.
} 
negociação política; que a nova retórica encontrava um objetivo eticamente defensável, de aplicação política prática e assim garantia para si um tema inesgotável, um conteúdo novo que a redefine em um nível superior ${ }^{70}$. Nestas linhas percebemos um esforço teórico, buscando soluções intermediárias, em graus, para manter-se então, artificialmente, a hipótese de que filosofia e retórica têm natureza diferentes.

Por fim, para separar a filosofia da retórica, Werner Jaeger aproxima esta da eloqüencia a ponto de quase identificá-las ao insistir que Isócrates não acredita na possibilidade de ensinar a virtude como não acredita na possibilidade de ensinar o senso artístico $^{71}$; que este, no seu discurso Antidosis, afirma que o novo conteúdo e mensagem de imensa responsabilidade política e moral que propõe é inseparável de uma também nova forma de eloqüência ${ }^{72}$; que, como o poeta Píndaro fizera, Isócrates também estabelece um paralelo entre as suas criações e as dos artistas plásticos e se compara a Fídias ${ }^{73}$ e que um tal modelo de saber implica em um ensino voltado para o uso do exemplo e do modelo o que é muito diferente do pensamento de Platão que aspira a formar a alma por meio do conhecimento de idéias que são normas absolutas do bom, do justo, do belo, etc. até conseguir realizar nela um cosmos inteligível que abarque a totalidade do $\operatorname{Ser}^{74}$.

No entanto, o próprio comentador deve reconhecer que Isócrates ofusca esta separação, entre filosofia e retórica associada à arte, quando este argumenta que a cultura superior retórica educa o homem por meio da linguagem e da palavra cheia de sentido e referida aos assuntos que são fundamentais à vida da comunidade humana e que os gregos chamavam de assuntos da polis, as máximas coisas humanas ${ }^{75}$; quando este mostra a importância de sua arte e a força da palavra como criadora de cultura, e até mesmo da própria comunidade humana, elevando o papel do retórico muito acima do nível dos

\footnotetext{
Jaeger, Werner, op. cit., p. 733.

Idem, p. 746.

Idem, p. 735.

Idem, p. 742.

Idem, p. 744.

Idem, pp. 820 a 821.
} 
representantes anteriores ${ }^{76}$; e especialmente quando este mostra que a finalidade da cultura retórica é a de criar o estado de perfeição da vida humana que chama, com os filósofos, de eudaimonia, i. e., um bem objetivo supremo ${ }^{77}$. E de fato, o filósofo Cícero, após defender a retórica do mal uso que dela se fizera, justificou seu maior interesse por esta arte, pois se era a fala que distinguia o homem dos animais - hac re maxime bestiis praestare quod loqui possunt - era justamente nesta qualidade que queria se distinguir dos outros homens - qua re homines bestiis praestent, ea in re hominibus ipsis antecellat. ${ }^{78}$

E recusando ao retórico a nomenclatura de "filósofo", Jaeger é ainda conduzido à outra dificuldade quando parece atribuir a Isócrates uma proposição filosófica, que posteriormente foi defendida por filósofos céticos. Segundo o comentador, Isócrates afirma que o ponto decisivo que permite ao retórico distinguir a cultura falsa da verdadeira é a convicção de que à natureza humana não é dado alcançar uma autêntica ciência no estrito sentido da episteme platônica do que devemos fazer ou dizer e por isto a verdadeira sabedoria consiste em descobrir com acerto, de modo geral e à base de simples opinião, o que é melhor para o homem e que, então, é ao homem entregue a este objetivo que se deve chamar de "filósofo". 79

Bem, em resumo, o comentador apresenta um pensador que não é filósofo, mas faz proposições filosóficas e invoca para si o título de "filósofo” no que ainda é apoiado por seus contemporâneos; parece realmente que há alguma dificuldade nesta separação artificial entre a filosofia e a retórica nas suas origens gregas, dificuldades que poderiam ser superadas pelo reconhecimento de que tanto há uma filosofia enquanto tradição de reflexão sobre o Ser e o próprio pensamento, chamada ainda hoje de metafísica, que segue o cânone platônico-aristotélico, quanto há uma filosofia enquanto tradição de reflexão sobre os problemas fundamentais do Homem e que alguns filósofos podem ter

\footnotetext{
76 Idem, p. 829. Também Erasmo pregará pela busca da erudição exortando a todos para que “ornem [em si mesmos, na sua mente] o templo do Senhor” com as armas [criações da tradição retórica] tiradas dos, assim considerados equivocadamente, pagãos inimigos; este pensador também enfrentará como Isócrates a acusação de criar um novo elitismo, reservando os céus apenas para os intelectuais.

77 Idem, p. 769.

${ }^{78}$ Cícero, De Inventione, Tradução de Henri Bornecque, Ed. Garnier Frères, 1954, Paris, p. 8.

79 Jaeger, Werner, op. cit., pp. 826 a 827 . Esta avaliação mereceria toda uma pesquisa para se verificar em que exato grau é justo atribuir a Isócrates o papel de antecipador dos argumentos céticos.
} 
colaborado com ambas as tradições ou têm suas reflexões reivindicadas por ambas, como talvez seja o caso daquelas associadas ao nome "Sócrates”.

Paul Oskar Kristeller com sua riquíssima obra sobre as fontes do pensamento renascentista ${ }^{80}$, é outro grande comentador da história do pensamento e suas avaliações, especialmente voltadas para o Renascimento e fundamentadas em extensa pesquisa bibliográfica, são indicadas mutuamente entre os poucos estudantes e especialistas brasileiros no período, mas apresentam uma dificuldade análoga àquela atribuída aqui a Werner Jaeger: se este, identificando filosofia à metafísica na antiga Grécia, distingue a filosofia da retórica porque esta não seria a busca e descrição da verdade, Kristeller faz a mesma identificação entre filosofia e metafísica na Europa renascentista para distinguir a filosofia do humanismo.

A série de problemas resultantes para o entendimento do pensamento filosófico neste período já começam com uma comparação entre os estudos sobre a história da filosofia e a historia da retórica: o historiador aceita como assentada a definição e a história fundamental da filosofia e se preocupa, no entanto, com a falta de trabalhos análogos quanto à retórica, porque talvez esta possua uma tradição menos contínua, e propõe o retorno aos seus significados originais e tradicionais em uso antes do século XIX como aqueles que já a Antigüidade clássica lhe atribuía entre outras conotações: como teoria do discurso, era um instrumento da política e da prática jurídica; como teoria do debate, se relacionava com a lógica e a dialética; como teoria da composição em prosa, tinha nexos íntimos com a poética e a crítica literária. A retórica também abordava a gramática, a teoria e a prática da historiografia; como despertava as paixões e recorria às sentenças morais, era relacionada com a ética e freqüentemente tomada por uma filosofia e, como programa de estudos avançados, foi por séculos rival, e quase sempre com maior sucesso, da filosofia e das ciências. Há ainda diferentes aspectos relacionados à história da retórica como a prática do falar - a oratória - e do escrever e as teorias que procuram descrevê-las ou regrá-las ${ }^{81}$.

\footnotetext{
${ }^{80}$ Kristeller, P. O.; El Pensamiento Renascentista y sus fuentes, op. cit.

${ }^{81}$ Idem, pp. 283 e 284.
} 
Já nesta passagem fica claro que, para o comentador, a filosofia e a retórica são áreas de conhecimento que se diferenciam, concorrem e mesmo se opõem. Também fica claro que para o comentador a retórica está próxima da teoria dos discursos, da prática jurídica como teoria do debate, da lógica, da dialética, da composição em prosa, da poesia, da crítica literária, da gramática e da teoria e prática da historiografia; surpreendentemente, quanto à reflexão sobre os problemas morais, o comentador atribui à retórica apenas o recurso à sentenças morais no que confunde-se com a eloqüência, a respeito da qual, principalmente, teoriza e propõe regras; atribuição muito diferente da percepção de Erasmo e outro humanistas que viam na retórica, o depositário natural dos textos de toda a filosofia moral. O impulso classificatório de um historiador pode abusar de etiquetas e encobrir a continuidade, na realidade, da sólida tradição da filosofia retórica, i. e., da filosofia enquanto retórica.

Se começam os problemas na teoria da classificação das áreas do saber, já começam igualmente as dificuldades na aplicação aos casos práticos desta distinção entre filosofia e retórica: considerando que em um sentido geral a retórica é a arte de falar bem e a filosofia a ciência que descobre e descreve a verdade, o comentador vê que estas atividades não somente coexistiam na Antiguidade, como em outras épocas, e freqüentemente competiam entre si, mas também se sobrepunham e invadiam uma o território da outra e se influenciavam mutuamente. Assim o comentador é obrigado a aceitar que não há apenas uma filosofia praticada por filósofos e para eles destinada, mas também uma filosofia implícita na retórica que os retóricos consideram domínio próprio e, por sua vez, não há apenas uma retórica criada por retóricos profissionais e a eles dirigida, mas também uma retórica que os filósofos ensinam como parte da filosofia ${ }^{82}$. Este é um resultado necessário e desnorteante da assunção por Kristeller do mesmo ponto de vista de Jaeger de que a filosofia não é retórica e vice-versa.

Kristeller reconhece o índice desta complexidade assumindo que esta se torna mais visível no fato de que Isócrates oferecia um programa de estudos que não se limitava apenas à retórica formal, mas abarcava também uma ampla instrução literária,

\footnotetext{
${ }^{82}$ Idem, p. 285.
} 
moral e política - a que ele mesmo chamava de filosofia - e foi o protótipo do humanista interessado na literatura e na ética, mas não nas ciências ou na filosofia técnica, especulativa; complexidade visível também no fato de que Platão, que no seu Górgias havia condenado completamente a retórica, já no diálogo Fedro passa a aceitar uma retórica disciplinada por considerações filosóficas e éticas e capaz de funcionar como instrumento da verdade; e visível por sua vez em Aristóteles que foi mais longe que os últimos escritos de seu mestre Platão no sentido de reconhecer o valor da arte de Isócrates, por certo, tendendo a mostrar na sua obra Retórica - um dos livros mais importantes sobre o tema na Antigüidade - que os filósofos estavam mais preparados que os próprios retóricos profissionais para ensiná-la e que esta arte, pela sua importância, é parte subordinada aos estudos filosóficos ${ }^{83}$. Nesta avaliação teórica se observa a coincidência de posições entre Kristeller e Jaeger e a associação dos humanistas ao nome de Isócrates lhes negando igualmente o status de “filósofos”.

Em seguida, o historiador ao tratar de Cícero informa que o seu De Inventione e a Rhetorica ad Herennium, que a tradição lhe atribui equivocadamente, constituem juntas o primeiro Corpus Latino de teoria da retórica ${ }^{84}$; que Cícero, como estudioso da filosofia grega e grande orador romano aprendeu parte de sua retórica dos escritos de Aristóteles e de mestres que teve na academia ateniense, o que é revelado pela sua inclinação para combinar, mais do que qualquer outro retórico profissional, a retórica com a filosofia e a considerar a primeira como parte e programa de uma educação e aprendizagem mais ampla.

Bem, esta distinção entre o que é filosofia e o que é retórica em um mesmo autor é tão artificial quanto difícil de perceber e então devemos nos dirigir às fontes - ad fontes. O próprio Cícero alega já ter recebido dos gregos a combinação de filosofia e retórica: (...) na mesma época de Aristóteles, viveu Isócrates, grande e conhecido mestre de eloqüência (...) destes dois grupos, que chamaria “família”, um tendia à filosofia, mas não negligenciava a retórica, o outro se consagrava exclusivamente ao estudo e ensino da eloqüência - Nam fuit tempore eodem, quo Aristoteles, magnus et nobilis rhetor Isocrates

\footnotetext{
${ }^{83}$ Idem, pp. 287 e 289.

${ }^{84}$ Idem. p. 293.
} 
(...) Ex his duobus diversis sicuti familis, quarum altera cum versaretur in philosophia, nonnullam rhetoricae quoque artis sibi curam assumebat, altera vero omnis in dicendi erat studio et praeceptione occupata ${ }^{85}$ - E aqueles que vieram depois as fundiram em uma escola nova e emprestaram das duas primeiras, para assimilá-las nos seus tratados, o que estas pareciam lhes oferecer de igualmente justo - unum quoddam est conflatum genus a posterioribus, qui ab utrisque ea, quae commode dici videbantur, in suas artes contulerant - Estes tratados nós os consideramos tanto quanto pudemos como precursores e, ao fundo comum, ajuntamos algumas observações próprias - quos ipsos simul atque illos superiores nos nobis omnes, quoad facultas tulit, proposuimus et nostro quoque nonnihil in commune contulimus $^{86}$. Ainda oscilando a respeito de Cícero, o historiador acrescenta que este dá nova vida ao ideal isocrático de um orador de educação sólida e filosófica e foi um dos primeiros a examinar em latim problemas filosóficos e a se preocupar em criar uma terminologia filosófica latina ${ }^{87}$. Este embaraço é refletido pela atual solução acadêmica que usa a questionável classificação de Cícero como filósofo “eclético" quando, se fosse amplamente aceito que a filosofia tem e continua uma tradição retórica, bastaria dizer que Cícero é "filósofo" como se diz a propósito de Rousseau, Voltaire, Diderot etc. sem que lhes sejam acrescentado o epíteto “eclético”.

Na ampla avaliação sobre a história da filosofia no Medievo, Kristeller propõe que, se no Oriente se deu a coexistência e ocasionalmente a rivalidade, entre filósofos e retóricos, no Ocidente estes dominaram por completo a educação e a cultura e não havia uma tradição filosófica que lhes fizesse concorrência ${ }^{88}$. Ora, esta apreciação não é aceita por Gilson que em toda sua famosa obra La Philosophie au Moyen Age - Des origines patristiques à la fin du XIV siècle, mostra que a especulação sobre o Ser inaugurada pelos gregos foi apropriada, vide absorvida, pelos especulativos cristãos interessados em estabelecer uma doutrina que respondesse às objeções de todos os sábios pagãos; lembre-se que este desejo genuíno de mostrar a superioridade da nova doutrina frente ao conhecimento assentado da época já é visível no famoso prólogo do evangelho de

\footnotetext{
${ }^{85}$ Cícero, op. cit., p. 135.

${ }^{86}$ Idem.

${ }^{87}$ Kristeller, P. O., op. cit., p. 294.

${ }^{88}$ Idem, p. 296.
} 
João: “No início era o Verbo”. E Gilson também mostra como esta ambição, que também é uma rivalidade, atravessa todo o Medievo e se prolonga até seu apogeu no escolasticismo do século XIII.

A partir desta discutível avaliação do Medievo, Kristeller explica a escassez e a falta de originalidade da filosofia antiga escrita em latim; o fato de que apenas algumas obras da literatura filosófica grega terem sido traduzidas para o latim e o fato de não ter ido longe o desenvolvimento de uma terminologia filosófica nesta língua, em que pese que Lucrécio e Cícero o tenham começado e Sêneca, Agostinho e Boécio o tenham continuado $^{89}$. Como resultado, duas obras de Aristóteles sobre a lógica traduzidas por Boécio e a metade do Timeo de Platão traduzida por Calcídio seriam os únicos textos de filosofia grega clássica que a Antigüidade romana em uma etapa final quis traduzir e legar aos séculos seguintes ${ }^{90}$. Mas a filosofia que depois de Cícero e Agostinho chega a Boécio, e sabemos que alcançou também Abelardo e outros até chegar aos escolásticos, é a filosofia enquanto tradição especulativa sobre o Ser que então continuou no Medievo assim como a filosofia enquanto tradição retórica. A desconsideração deste fato leva Kristeller a concluir que Agostinho e demais Pais da Igreja, tais como Tertuliano, Lactâncio e Ambrósio, revelaram interesse pela filosofia, mas que a maioria destes, educados pela cultura romana eram versados e mesmo profissionais em retórica e jurisprudência, mas não em filosofia ${ }^{91}$.

Kristeller ainda lembra que no Medievo a retórica forma com a gramática e a dialética o trivium que, somado ao quadrivium, constitue o programa de estudos das sete artes liberais $^{92}$, concordemos com isto - demus istud. Parece que esta classificação medieval da retórica como uma das sete artes liberais já colabora para a atual imediata associação entre retórica e eloqüência ou literatura. Mas, à frente em sua obra, o comentador acrescenta que as sete artes liberais eram vistas em conjunto no medievo como “filosofia”, o que corrobora o entendimento que propomos da retórica como tradição filosófica enquanto reflexão sobre os problemas fundamentais do Homem, no entanto o

\footnotetext{
89 Idem, p. 296.

${ }^{90}$ Idem, p. 298. Exemplo de julgamento que define filosofia apenas como a tradição de reflexão sobre o Ser como inaugurada pelos pré-socráticos e estabelecida pelos cânones de Platão e Aristóteles.

91 Idem, p. 298.

92 Idem, pp. 298 e 299.
} 
comentador prossegue e acrescenta que isto se deveu ao fato de que as artes liberais eram compreendidas como a soma total dos conhecimentos disponíveis e que este período desconhecia o sentido técnico grego da palavra "filosofia". Ora, o comentador entende apenas como metafísica o sentido técnico de filosofia e lhe escapa o que outros séculos viram corretamente.

Voltando-se para uma ampla avaliação da história da filosofia no Renascimento, Kristeller propõe que, se na Antigüidade romana e Idade Média o domínio da retórica era completo frente à filosofia - como também foi em certos períodos da Antigüidade grega - no Renascimento, que tem por característica o estudo, imitação e culto da Antigüidade clássica, depois do período das repúblicas italianas, ela não se interessará, diferentemente da retórica antiga, pelo discurso político; se afastará das disputas jurídicas e deverá sempre competir com a filosofia e a teologia escolástica assim como com as novas disciplinas profissionais das leis, medicina, matemática, artes e literatura popular, entre outras, mas crescerá constituindo novos campos da civilização ${ }^{93}$. No entanto esta avaliação da história da retórica se limita a considerar apenas sua manifestação pública através da arte da eloqüência e a grande dificuldade desta interpretação do comentador está em definir o conteúdo desta eloqüência: se for apenas composta de regras e estratégias da oratória, não poderia competir com a filosofia e a teologia, mas se tem conteúdo suficiente para competir com estas, porque não entendê-la como também uma tradição da filosofia que não se confunde com aquela da reflexão sobre o Ser ?

O historiador prossegue: aqueles que eram considerados como oradores e poetas passam a ser conhecidos por "humanistas" e divulgam um novo programa de ensino que chamam de Studia Humanitatis, que inclui gramática, poesia, história, filosofia moral e retórica, e que começa a dominar a educação secundária, a influir nas universidades e revivendo um ideal de Cícero - se volta para o estudo da literatura antiga em busca da combinação da eloqüência com sabedoria, i. e., da retórica com a filosofia ${ }^{94}$. Esta nova proposição embaralha novamente o sentido que o comentador deseja dar ao movimento

\footnotetext{
93 Idem, p. 322.

94 Idem, p. 323.
} 
humanista como movimento cultural de mestres da retórica afastados, vide estranhos, à filosofia.

As avaliações do comentador chegam ao humanismo: existem vários humanismos na civilização renascentista, pois - além do humanismo cívico que manifestou seu ponto culminante na aliança entre o humanismo e o pensamento político em Florença, entre outras cidades - há no conceito de humanismo um certo número de idéias morais e de outros tipos que não eram nem políticas nem sociais assim como muitas iniciativas literárias e culturais sem ligação clara e necessária com o pensamento filosófico ${ }^{95}$. Bem, talvez esta proposição pudesse ser invertida com maior vantagem para a compreensão da Renascença: o “certo número de idéias morais” - na realidade um conjunto tradicional de idéias sobre as questões fundamentais do Homem, o que inclue toda a filosofia moral, política e a teologia - herdado da Antiguidade e do Medievo é sim, desde o século XIX, identificado sob o conceito facilitador de "humanismo". Também, é possível notar criticamente que a facilidade com que se fala no plural de "humanismos" e com a qual são diferenciados como, e. g., "humanismo cívico”, "humanismo literário” etc., pode obscurecer o fato de que há na realidade uma fundamental e única tradição retóricofilosófica grega de precisas questões com aportes latinos e medievais que floresce na Renascença dividindo-se em ramos que se entrelaçam e se fortalecem com a chegada e tradução de textos clássicos que jamais haviam sido lidos na Europa ocidental.

Na reunião de dados, percebe-se como um historiador é capaz de mobilizar grande número de fontes, mas nem sempre de oferecer alguma interpretação, como é o caso da seguinte passagem: a retórica na Renascença ganha novos sentidos pois, se no esquema das sete artes liberais do Medievo ela se ligava mais estreitamente à gramática e à dialética formando o trivium, identificado por sua vez com o estudo da Lógica - uma das três partes tradicionais de filosofia com a Ética e a Física - depois do surgimento das universidades no século XII e XIII, as artes da retórica e da gramática passarão a ser limitadas ao ensino secundário enquanto a dialética, mais valorizada,

${ }^{95}$ Idem, pp. 324 e 325. 
identificada e chamada agora isoladamente de Lógica, se unirá à filosofia natural - a Física - e às outras disciplinas filosóficas e cientificas nos nascentes cursos superiores. ${ }^{96}$

É visível o esforço do historiador na compreensão do movimento dinâmico das classificações da cultura, mas talvez seja o caso de lembrar que as universidades nasceram sob a proteção e controle da Igreja e espelharam sua prioridade no estudo, debate e tentativa de superação da tradição especulativa grega sobre o Ser na busca de sua conciliação com a doutrina cristã para mostrar a unidade entre fé e razão. Então, à época, o que as universidades chamavam de filosofia profana era unicamente a parte da filosofia ou melhor a parte das sete artes liberais que lhes interessavam epistemo ou politicamente que era a dialética, a “mais valorizada”.

A complexidada das idéias filosóficas em jogo sob a dinâmica das classificações das disciplinas na Renascença, leva o comentador a uma pura descrição de fatos da cultura seguida de uma surpreendente conclusão quase às avessas daquele pressuposto que ele próprio sustenta que a filosofia é distinta da retórica: a retórica com a gramática, perdem sua antiga ligação com a dialética no trivium e passam a integrar o que se chamará Studia Humanitatis - programa de ensino secundário que é preliminar aos estudos universitários e que substitui gradativamente o programa medieval das sete artes liberais - e a se relacionar agora com a filosofia moral e com a poesia e a história, que lhe eram submetidas no medievo antes de se tornarem independentes. Ocorre também que esta última, a filosofia moral, identificada com a Ética, é reivindicada pelos humanistas e desvinculada da Física e da Lógica, as duas outras partes muito mais técnicas ou científicas da antiga divisão da filosofia cujo estudo, por sua vez, passa a se concentrar nas universidades ao lado das matérias novas, diferentes ou emancipadas frente às artes liberais, tais como a teologia, medicina e jurisprudência, que exigiam estudos mais avançados. A conclusão a que chega Kristeller é a de que este novo quadro acaba por recuperar o modelo antigo de Isócrates e Cícero no sentido talvez em que volta a reunir sob o nome de Studia Humanitatis disciplinas que têm por meta o conhecimento do Bem e dos meios para

\footnotetext{
${ }^{96}$ Idem.
} 
alcançá-lo ${ }^{97}$. Bem, o comentador reconhece que o "novo quadro acaba por recuperar o modelo antigo de Isócrates e Cícero” e este é amplamente reconhecido como filósofo.

Também nesta explicação das mudanças na organização do ensino, tudo faz parecer que, se para os retóricos antigos as mathemata, agrupadas na Antigüidade latina sob o nome de quadrivium, são propedêuticas às disciplinas responsáveis pela formação da linguagem, discurso e pensamento que são a gramática, retórica e dialética, i. e., o trivium mais próximas que qualquer outra disciplina na busca do conhecimento dos valores e suas conseqüências práticas - então ocorreria uma inversão nas universidades renascentistas que colocam estes studia como anteriores e assim propedêuticos para o ensino da Lógica, da Física ou da medicina, jurisprudência e outras disciplinas mais práticas ou profissionais. Bem, ousamos perguntar se não seria o caso de separar estes dois fenômenos, recusando o anacronismo no pensar que esta inversão inaugura o quadro atual que dá pouca prioridade para o estudo das humanidades, e se não seria antes conveniente reconhecer com Gilson, como já apresentado, que a Igreja, que controlava as universidades e tinha necessidade urgente de responder ao aristotelismo averroísta, entendia e fazia entender o significado da filosofia apenas enquanto tradição de reflexão sobre o Ser - vide metafísica - e não enquanto tradição retórica. Esta tradição retórica, portanto, distante das questões metafísicas que interessavam com urgência à Igreja, desde a época dos padres que desconheciam a profundidade do problema aristotélico para a fé, continuou a ser cultivada por seus próprios méritos, interesse e conteúdo fora das universidades dando continuidade a uma longa tradição que não se fazia subordinar por qualquer instituição, mas antes à ampla necessidade de reflexão sobre os problemas do Homem como reivindicará claramente Petrarca.

Além de se apoiar nas pesadas classificações da cultura, Kristeller busca provas materiais para separar a filosofia da retórica: no Renascimento a presença da retórica se faz sentir em muitos outros campos da cultura de maneira também evidente como na epistolografia - dado que as cartas particulares serviam à intenção literária e retórica e eram colecionadas e publicadas pelos próprios autores - no ensino, onde

\footnotetext{
${ }^{97}$ Idem, p. 325.
} 
produziam grande volume de modelos de discursos e cartas para serem imitadas, nos discursos de todos os tipos, incluindo aqueles realizados por laicos e clérigos fora e dentro da igreja e aqueles no vernáculo, no estudo da gramática que tinham por objeto o domínio correto do latim - a exemplo do Elegantiae Linguae Latinae de Lorenzo Valla - na historiografia, onde se seguindo fielmente o padrão da Antigüidade chegava-se a incluir discursos fictícios, e afinal na poesia. Nesta, a retórica não apenas estava presente, mas havia, mais exatamente, uma mútua influência e paralelismo entre estas artes na medida em que a retórica, de maneira geral, se afastava da persuasão e da ação política e procurava o falar e escrever bem, especialmente sobre o influxo combinado da Retorica e da Poética de Aristóteles no século XVI antecedidos por tratados e estudos sobre a poética em Platão e Horácio já no século $\mathrm{XV}^{98}$.

Nesta apreciação, o comentador reconhece a presença da retórica em vários campos: epistolografia, oratória, gramática, historiografia e poesia e conclui que a retórica em seguida se reduz à arte da eloqüência e do bem escrever. Esta descrição compartimentada de saberes com mudanças surpreendentes quase faz crer em uma mecânica entre blocos de saberes, algo longe da flexibilidade e fluidez que observamos nas coisas da cultura. Talvez a compreensão de que há na verdade um “caldo de cultura”, uma tradição filosófica retórica herdada do classicismo que empresta conteúdo, estofo, matéria para a epistolografia, oratória, gramática, historiografia e poesia mostre que a retórica longe de se reduzir apenas a uma das expressões profissionais da cultura, é um conhecimento que se espraia em várias vertentes e mesmo floresce com a chegada de novos acervos retóricos guardados e cultivados pelos bizantinos e árabes; uma tradição filosófica retórica que ao tratar das questões fundamentais do Homem - diferentemente da tradição filosófica que se ocupou da reflexão sobre o Ser - criou um patrimônio particular e complexo de perguntas e respostas que se apresentam com todo o colorido expressivo da invenção - inventio humana e tornam inseparável o conteúco da forma.

Novas dificuldades se apresentam, pois o historiador reconhece a seguir que os humanistas ofereceram novas traduções de Aristóteles que competiam com as

${ }^{98}$ Idem, pp. 328 a 335. 
versões medievais e trouxeram à luz alguns de seus comentaristas gregos ainda desconhecidos no Ocidente e com isto propiciaram comparações e alternativas autorizadas aos comentários de Averroes e de Tomás de Aquino; que, além disto, os humanistas insistiram que o estudo de Aristóteles deveria utilizar os originais gregos e alguns chegaram mesmo a preferir este autor colocando-o acima de outros pensadores assegurando que o entendiam melhor que seus intérpretes escolásticos; que aconteceu mesmo que entre os séculos XV e XVI os humanistas se apropriaram quase por completo da Retórica e da Poética assim como da Ética, da Política e de outros escritos morais de Aristóteles ${ }^{99}$. Então, o historiador mostra humanistas como tradutores de filósofos e de seus tradicionais comentaristas e mesmo capazes de se posicionar a respeito destes e de criticarem filósofos escoláticos contemporâneos, mas lhes nega o caráter de “filósofos” como se estes tivessem sido anacronicamente apenas tradutores técnicos profissionais como os atuais e não como sólidos intelectuais engajados pessoalmente na recuperação e assimilação crítica do classicismo para a sua época.

Pode-se observar um problema análogo, quanto Kristeller também reconhece que os humanistas são tão mais claramente devedores para com os escritos platônicos e neoplatônicos que se torna necessário um esforço crítico para se separá-los dos filósofos platônicos renascentistas; que, outrossim, é necessário outro esforço para mostrar nestes inclusive alguns influxos do escolasticismo aristotélico, e. g., Marsilio Ficino e outros produziram as primeiras traduções completas de Platão e de neoplatônicos continuando o trabalho dos humanistas, mas se interessavam mais pela doutrina filosófica que pela forma literária, sem recusar absolutamente a retórica defendida pelo próprio Platão no seu Gorgias. Já Pico della Mirandola, um dos mais famosos humanistas, também tende a ressaltar o conteúdo em detrimento da forma, a separar a filosofia da retórica e argumenta a favor dos escolásticos em uma famosa polêmica contra Ermolao Barbaro ${ }^{100}$. Esta é uma nova série de échecs e paroxismos manifestados na tentativa sistemática de sustentar a separação artificial entre humanistas e filósofos reconhecendo que alguns humanistas escrevem como filósofos, mas não são filósofos e filósofos que não são humanistas, mas se interessam por assuntos humanistas. Talvez seria mais simples observar intelectuais que na

$99 \quad$ Idem, p. 337 e 338.

100 Idem, p. 343. 
fervilhante Renascença se interessam por uma tradição filosófica ou outra, e mesmo pelas realizações das duas como Pico della Mirandola.

Kristeller, enfim, avança de maneira clara sua tese sobre os humanistas: os filósofos renascentistas foram aristotélicos, platônicos, neoplatônicos ou filósofos da natureza e mostraram pouco interesse pela retórica ou pela poética e afastaram-se destes campos em que dominaram os humanistas que foram pensadores, eruditos, escritores, professores, políticos, altos burocratas, nobres, religiosos, artistas - i. e., herdeiros emancipados de profissões medievais como a ars dictaminis ${ }^{101}$. No entanto, o comentador apresenta os humanistas como diretos continuadores da profissão medieval da ars dictaminis, e podemos nos perguntar se esta tese sobre o humanismo é adequada especialmente ao humanismo representado por Erasmo - pois ao se buscar ver metodologicamente nos humanistas os continuadores de profissões medievais pode-se supervalorizar algumas continuidades, traços materiais em uma consideração formal que no entanto, parece não possuir fôlego para a compreensão, e. g., do surgimento de intelectuais humanistas no interior das Igrejas Católica e Protestante, entre os nobres, que por definição não trabalham, e profissionais liberais engajados e movidos antes de tudo pela intuição ética fundamental ${ }^{102}$, sua firmissima ratione - como propôs Cícero no seu De Inventione de que o nosso conhecimento da natureza resulta inútil se não conhecemos a natureza do Homem e seu fim que é então o assunto verdadeiramente importante para o pensamento.

A seguir, Kristeller apóia sua tese em observações ácidas: os humanistas foram tradutores responsáveis pelo resgate e renascimento de sistemas antigos, e. g., o estoicismo, o epicurismo e o ceticismo, como alternativas ao aristotelismo e ao neoplatonismo, únicos conhecidos dos filósofos medievais, mas não foram a rigor filósofos profissionais, pois seus escritos em geral carecem comparativamente de precisão nos termos e de consistência na lógica da argumentação, suas opiniões são às vezes contraditas por passagens de obras diferentes - até em uma mesma obra - além de serem repelidas ocasionalmente pelas opiniões de outros humanistas. Suas opiniões podem ser originais em seu conteúdo ou em certos detalhes, mas em muitos casos se tratam de mera repetição ou 101 Idem.

${ }^{102}$ Kristeller e Randall Jr., op. cit., pp. 110 a 101. 
variação de idéias filosóficas anteriores; buscando ser tão ecléticos quanto Cícero, deu-se que muitos de seus esforços filosóficos mais consistentes foram transposições de doutrinas anteriores $^{103}$. Ora, o comentador, para separar metodologicamente os humanistas dos filósofoso, utiliza o critério de sistematicidade, que corresponde já a uma avaliação datada; atualmente, este critério eliminaria o próprio Platão do rol dos filósofos. Também a transposição de doutrinas anteriores não pode ser vista como desvantagem, mas antes como o próprio fio condutor e constituidor da história da filosofia.

Comparando os humanistas com os filósofos, Kristeller, mostra uma determinada fragilidade na sua interpretação dos fatos: em contraste marcante com os humanistas, os filósofos profissionais aristotélicos ligados já há alguns séculos ao sistema universitário, os escolásticos, dispunham de um material de origem para estudos, método e terminologia consistentes e precisos para o estudo da lógica e da natureza; possuíam um conjunto de definições e problemas e um método de examinar estes problemas comuns que eram menos um sistema compacto de doutrinas uniformes que uma diversificada tradição de ensino. Esta opção didática pelo aristotelismo feita pelas universidades havia se constituído lentamente - depois de um período inaugural agostiniano a partir da segunda metade do século XI - com o afluxo de traduções árabes e cópias gregas de originais de Aristóteles e de seus comentaristas que culminou no século XIII com sua introdução na instrução sistemática de disciplinas filosóficas, em especial da lógica e da filosofia natural, não só pelo exemplo árabe, mas principalmente pela solidez de seu conteúdo e seu caráter sistemático e enciclopédico ${ }^{104}$.

Ora, a leitura de Étienne Gilson, faz ver que esta "solidez do conteúdo e caráter sistemático” eram na verdade desdobramentos árabes - vide averroísmo - da específica tradição filosófica constituída pela reflexão grega sobre o Ser que trazia para a Europa ocidental uma nova definição da demonstração racional que exigia o urgente e prioritário estudo, reflexão e discussão para o crucial esforço de sua compatibilização e assimilação à doutrina cristã, esforço vital para a Igreja que mantinha as primeiras universidades. É anacrônico pensar que havia no início das universidades, e mesmo durante

103 Kristeller, P. O., op. cit., pp. 335 e 336.

104 Idem, pp. 57, 58 e 209. 
a Renascença, sob a opção escolástica por Aristóteles, um esforço industrial em se fazer ciência, o esforço não era voltado para um futuro, mas para a compreensão de textos teológicos do passado, textos que tratam do prioritário problema da salvação; é lenta e secundária, na origem das universidades, a restauração das antigas disciplinas naturais e jurídicas que, inclusive, dependerão dos esforços humanistas na recuperação das antigas disciplinas. Portanto a diferença entre escolásticos e humanistas se deve menos a uma suposta superioridade metodológica de escolásticos e mais uma diferença de problema e método.

Surpreendentemente, isto é em parte aceito em outra passagem desta obra de Kristeller: é mais apropriado compreender-se o humanismo e o escolasticismo como duas tradições que se desenvolveram lado a lado por todo o Renascimento em setores distintos de atividade intelectual - o humanismo no campo da gramática, retórica, poesia, história e filosofia moral e o escolasticismo nos campos da lógica e da filosofia natural; e mais correto pensar a suposta disputa antes como uma rivalidade entre dois departamentos que um choque entre doutrinas filosóficas opostas ${ }^{105}$. Esta avaliação mereceria apenas o acréscimo de que a gramática era o estudo do Latim através de textos e que estes textos somados àqueles da poesia, história e filosofia moral eram depositários naturais de todo o patrimônio remanescente da filosofia enquanto retórica, i. e., enquanto reflexão sobre os problemas fundamentais do Homem; então seria mais adequado pensar o escolasticismo como continuação da longa reflexão filosófica grega sobre o Ser em oposição, não a algo chamado recentemente de "humanismo", mas a outra longa reflexão grega, chamada por eles mesmos de "retórica” e que trata dos problemas fundamentais do Homem; tradições que, realmente, se desenvolvem em paralelo e por vezes, com rivalidades. Assim, concordamos que estas duas tradições não constituem doutrinas filosóficas opostas não porque não sejam ambas igualmente pensamento filosófico, mas porque tratam de questões de natureza diferente e com métodos diferentes.

No entanto, há outros argumentos do historiador que ainda devem ser enfrentados: há uma passagem em que este afirma que não é correto confundir ${ }^{105}$ Idem, pp. 142 e 143. 
ingenuamente os humanistas com os filósofos platônicos renascentistas ou pensar que estes são parte ou derivação do humanismo, pois se em alguns escritores singulares eles podem ser inextricáveis, em geral é mais correto pensar em mútua influência porque o humanismo forneceu temas urgentes para serem pensados pelos filósofos platônicos e estes apresentaram várias proposições extremamente compatíveis com a necessidade de fundamentação teórica dos temas do humanismo, e. g., a imortalidade da alma, a unidade da verdade, o otium cum litteris, etc. ${ }^{106}$

Ora, há um problema quando se assume o dever de sustentar como entidade o que pode não passar de um nome: para a manutenção e justificação de um suposto "movimento da cultura" chamado de "humanismo", diferenciando-o da filosofia, o comentador se vê obrigado a dividir as tarefas intelectuais reservando para o "humanismo" o papel de "estimulador" de outras áreas com temas próprios, mas sem criar algo propriamente por si só. Mas como pensar em intelectuais que se interessam por temas sem tratá-los? Afinal, como saberíamos que possuíam estes interesses? Também a expressão “filósofos de formação humanista” utilizada pelo comentarista ${ }^{107}$, torna evidente o esforço para se salvar a noção de "humanismo" dando-lhe alguma função, pois com Gilson poderíamos, afinal, falar tranqüilamente da Renascença e de seus intelectuais sem usar a categoria "humanista" preferindo pensar em duas tradições filosóficas concorrentes que mesmo, por vezes, interessaram ao mesmo pensador: a tradição da filosofia enquanto reflexão sobre o Ser, a metafísica, e a tradição da filosofia enquanto reflexão sobre os problemas fundamentais do Homem, a retórica.

Afinal, na visão pessoal de Kristeller, o humanismo lhe parece um programa e esforço cultural e educativo interessado no estudo intenso e extenso da literatura clássica grega e, especialmente, latina - que incluía certamente uma disciplina filosófica, a moral - mas excluía por definição campos inteiros como a lógica, a filosofia natural e a metafísica assim como as matemáticas, a astronomia, a medicina, as leis, a teologia, áreas firmemente estabelecidas nas atividades universitárias e sua

\footnotetext{
${ }^{106}$ Idem, p. 52.

${ }^{107}$ Idem, p. 84.
} 
nomenclatura ${ }^{108}$. Neste visão de conjunto, entre outros aspectos, não se pode concordar que os humanistas não tenham se interessado pela teologia, pois todos são herdeiros diretos não da Grécia e Roma pagã, mas da Roma Imperial convertida ao cristianismo que atravessa um milênio inteiro de prioritária especulação teológica; é fácil mostrar como quase todos os humanistas, de Petrarca a Erasmo, se interessaram por temas religiosos.

Também merece uma última consideração, um pensamento do comentador que resume seus argumentos sobre o humanismo: todas estas ações [magistério, secretários de príncipes e cidades, escritores de cartas, discursos e obras históricas, editores de manuscritos antigos] fazem do humanismo antes uma fase da retórica na cultura ocidental que remonta aos sofistas gregos ${ }^{109 ”}$. Esta generosa e ampla sentença apenas poderia ser mais precisa, talvez, se indicasse antes o humanismo renascentista como fase característica da tradição retórica da filosofia e assim, por desdobramento, de toda a cultura ocidental.

Enfim, para concluir com imagens fortes esta visita crítica à importante e influente obra de Kristeller, seria útil uma visão panorâmica apenas dos problemas que este oferece em geral para a compreensão da obra de Erasmo: para o historiador o humanismo é tomado apenas por um largo movimento cultural erudito e literário ${ }^{110}$ ou apenas por um programa cultural e educativo ${ }^{111}$; que este haja apenas preparado o terreno para que filósofos profissionais posteriores tratassem dos problemas genuínos e mais concretos da filosofia moral ${ }^{112}$; que seus livros apenas tenham mostrado um pensamento eclético dedicado a recolher migalhas de conhecimento onde pudessem encontrar ${ }^{113}$; que a influência indireta do humanismo no pensamento renascentista tenha sido mais importante que sua contribuição direta ${ }^{114}$; que tenha apenas revivido a sabedoria antiga ou dado nova vida ou nova expressão às doutrinas filosóficas de certos pensadores ou escolas antigas ${ }^{115}$;

\footnotetext{
${ }^{108}$ Idem, pp. 139 e 140.

109 Idem, p. 41.

${ }^{110}$ Idem, p. 82.

${ }^{111}$ Idem, p. 40.

112 Idem, p. 47.

113 Idem, p. 48.

${ }^{114}$ Idem, p. 49.

${ }^{115}$ Idem, p. 50.
} 
que o humanismo tenha apenas colecionado noções e conseqüências filosóficas e que não se pode descobrir no humanismo nenhuma doutrina filosófica geral a não ser a crença no valor do Homem e das humanidades e na renovação da sabedoria antiga ${ }^{116}$; que um enunciado tirado da obra de um humanista possa mais facilmente ser contradito por afirmações de um de seus colegas e inclusive dele próprio ${ }^{117}$; que o humanismo tenha sido apenas um processo de fermentação intelectual ou digestão do abundante número de idéias e noções recém chegadas ao Ocidente ${ }^{118}$; que os humanistas tenham sido apenas retóricos profissionais com uma idéia nova e classista de cultura que intentaram afirmar a importância de seu campo de atividade e impor suas normas a outros campos de aprendizagem e à ciência, incluindo a filosofia ${ }^{119}$; que os humanistas tenham carecido de originalidade, senão de coerência, método e substância a ponto de que, quando tentamos resumir seus argumentos e conclusões deixando de lado citações, exemplos, lugares comuns, adornos literários e digressões com freqüência acabamos de mãos vazias ${ }^{120}$; que houve no humanismo a ausência relativa de um pensamento científico ou filosófico e que enfim, os humanistas tenham se proposto apenas o falar bem ${ }^{121}$ e não tenham sido filósofos $^{122}$.

Assim, a interpretação que Kristeller faz do humanismo como movimento cultural da Renascença forjado por retóricos continuadores de profissões medievais principalmente da ars dictaminis - em contraste com o que chama de "filósofos

\footnotetext{
${ }^{116}$ Idem, p. 51.

${ }^{117}$ Idem.

118 Idem.

${ }^{119}$ Idem, p. 126.

${ }^{120}$ Idem, p. 47. "La mayoría de esos tratados - sean sus autores Petrarca, o Salutati, Bruni o Valla, Poggio o Filelfo, Francesco Barbaro o Leone Battista Alberti - son obras de escritores o sabios consumados, si bien a los ojos de un lector acostumbrado a las obras de los grande filósofos griegos, escolásticos o modernos puedan parecer un tanto aficionados. A menudo se dirá que carecen no sólo de originalidad, sino de coherencia, método y sustancia, y quando intentamos resumir sus argumentos y conclusiones - dejando a parte citas, ejemplos, lugares comunes, adornos literarios o digresiones - com frecuencia nos quedamos com las manos vacías.”.

${ }^{121}$ Idem, p. 131. "Sin enbargo, los humanistas se proponíam tan sólo el hablar bien, de acuerdo com sus gustos y con la ocasión y queda por verse si tuvieron menos fortuna en este sentido que sus predecesores medievales o que sus sucesores modernos. Aunque muestras de 'retórica vacía', sus discursos nos proporcionan una sorprendente cantidad de informacíon sobre la vida personal e intelectual de aquellos tiempos".

122 Idem, p. 124. "Me inclino por sugerir que los humanistas italianos no eram ni buenos ni malos como filosofos; simplemente no eran filósofos”.
} 
profissionais” ${ }^{23}$ aristotélicos, platônicos, etc., coincide com a posição de Jaeger que contrapõe a filosofia, enquanto busca e exposição da verdade, à retórica ${ }^{124}$ enquanto continuadora da arte dos sofistas que desconfiam da possibilidade de encontrar uma verdade inquestionável, mesmo considerando que estes chegam a alcançar com Isócrates temas fundamentais para o Homem a partir de uma perspectiva também ideal e não submetida ao interesse político particular.

Este quadro representa em grande parte as indecisões, incoerências e dificuldades que chegam amplificadas ao senso comum no seu esforço em compreender exatamente como os pensadores renascentistas se vinculam à tradição do pensamento filosófico. No entanto, deixando-nos guiar por Étienne Gilson ${ }^{125}$, somos convencidos paulatinamente de que ambos os comentadores chamam de "filosofia" o que deveria ser chamado mais propriamente de "metafísica”, i. e., de filosofia enquanto tradição de reflexão sobre o Ser e que Kristeller, especialmente, ora recusa, ora vacila em reconhecer a existência de humanistas filósofos ${ }^{126}$, talvez por não se permitir relativizar classificações recentes da cultura como "humanismo" e "humanistas" ${ }^{27}$, que poderiam se tornar mesmo desnecessárias se fosse aceito simplesmente que na Renascença, paralelamente à filosofia enquanto tradição de reflexão sobre o Ser, houve a continuidade e florescimento da

\footnotetext{
123 Idem, p. 47.

${ }^{124}$ O registro baixo da retórica: aqui é necessário lembrar que, seguindo a tradição platônica e ciceroniana, para Erasmo também há um sentido condenável da palavra "retórica » enquanto pura « eloqüência », pois observa que há um bom e um mal uso desta arte, como podemos confirmar em seu La Langue: "Dans la ville même d'Athènes, mère nourricière de tous les arts raffinés, le nom de sophiste fut l'objet d'une hostilité étonnante; ces gens professaient à cette époque la rhétorique, mais davantage pour se montrer que pour traiter les sujets sérieux. Ces arguments ne visent pas à condamner un art que même Aristote, le très grand et serieux philosophe, n'hesita à presenter en détail (...) l'art qui surpasse presque tous les autres en beauté jouit d'une mauvaise réputation chez la plupart des hommes à cause de ses affinités avec ce défaut". Exemplos da má retórica: "Des hommes le plus souvent complètement 'dépourvus de culture' possèdent bien alors les tours de la rhétorique. Ce qui est absurde, c'est que, tout en déversant absolument partout le pus de leur esprit, ils jurent (...)” p. 221, e “Et ils sont rompus à ces artifices, eux que se font une religion d'étudier la rhétorique (...)” p. 216, (op. cit., p. 97).

${ }_{125}$ Gilson, Étienne, Philosophie au Moyen Age - Des origines patristiques a la fin du XIV siècle, op. cit.

${ }^{126}$ O que, é claro, conceitualmente diferente de "filósofos humanistas" como o comentador classifica o que chama de "filósofos profissionais” com interesse nos temas humanista; todas estas articulações seriam dispensáveis se víssemos apenas pensadores renascentistas que se incluem na tradição grega dos escritos filosóficos enquanto reflexão sobre o Ser ou enquanto reflexão sobre os problemas fundamentais do Homem e seu Bem ou ainda, ocasionalmente, nas duas.

127 A relativização destes termos não impede a continuidade de seu uso, desde que já se incorporaram à historiografia e ao senso comum.
} 
filosofia enquanto tradição retórica de reflexão sobre questões fundamentais do Homem e seu Bem.

A questão se torna delicada quando se observa que estas duas tradições filosóficas se prolongam e convivem hoje nas universidades, assim como disputavam prestígio na Renascença: o próprio Erasmo não condena o amplo estudo das disciplinas que tratam da natureza com o auxilio da gramática, retórica, e dialética - as disciplinas da natureza podem mesmo favorecer a compreensão da Bíblia - mas como humanista, claramente reivindica a prioridade para a tradição da filosofia como retórica, pois são os textos retóricos que tratam das questões fundamentais do Homem ${ }^{128}$ e que por isso possuem letras mais humanas - humaniores litterae - e deplora que aquela longa reflexão platônicoaristotélica, que se apresenta como científica e autônoma com o largo emprego da lógica e da dialética, seja barbaramente ${ }^{129}$ assimilada inclusive por disciplinas que tratam dos

${ }^{128}$ O registro alto da retórica: de acordo com o indagador personagem “Sócrates” dos diálogos de Platão e com Cícero e diferentemente dos escolásticos continuadores da filosofia enquanto especulação sobre o Ser, Erasmo alinha-se a Petrarca na opção pela filosofia enquanto tradição retórica que trata das questões fundamentais do Homem e o conhecimento de seu Bem, cujos textos são tratados na Renascença pelos Studia Humanitatis, como vemos em Cassirer, Kristeller, Randall Jr, que reproduzem o seguinte trecho de Petranca em seu On his own ignorance and that of many others: "What is the use - I beseech you - of knowing the nature of quadrupedes, fowls, fishes, and serpents and not knowing or even neglecting man`s nature, the purpose for which we are born, and whence and whereto we travel?”. Também na p. 103, podemos ler esta crítica de Petrarca à Ética Nicomaquéia de Aristóteles: "Sometimes I have perhaps become more learned through them when I went home, but not better, not so good as I ought to be; and I often complained to myself, occacionaly to others too, that by no facts was the promisse fulfilled which the philosofer makes at the beginning of the first book of his Ethics, namely that "we learn this part of philosophy not with the purpose of gaining knowledge but of becoming better". Estes autores ainda trazem nesta mesma p. 44 trechos do The Ascent of Mont Ventoux onde lemos que no alto deste monte o poeta encontra ao acaso, em uma pequena cópia manuscrita das Confessio de Agostinho, a seguinte sentença que julga inesperadamente apropriada para si e para tantos outros estudiosos: "And men go to admire the high mountains, the vast floods of the sea, the huge streams of the rivers, the circunference of the ocean, and the revolutions of the stars and desert themselves" (op. cit, pp. 58 e 59). Erasmo, em seu Antibarbarorum, apontando os inimigos dos Studia Humanitatis acusa entre outros os "doutos ignorantes" - indocte docti - de se interessarem apenas pelas ciências da natureza ou jurídicas ou então pela dialética aplicada à teologia, desprezando as letras humanas humanitatis litteras - sem as quais todo conhecimento é cego - sine quibus caeca est omnis doctrina (op. cit. $1704 \mathrm{~F})$.

${ }^{129}$ No Antibarbarorum os bárbaros são os ignorantes e relutantes clérigos adversários das letras clássicas, mas Erasmo, com sua sensibilidade literária formada pela retórica, também classifica de bárbaro o uso da maquinaria lógica e do procedimento dialético no tratamento das questões da filosofia moral e da teologia. 
assuntos divinos e mesmo daquelas questões urgentes para a vida prática do indivíduo como a teologia e a filosofia moral. ${ }^{130}$

Mas havia razões ainda mais profundas e refletidas para Erasmo deplorar que esta tradição filosófica platônico-aristotélica de reflexão sobre o Ser - a metafísica fosse aplicada desde antes da queda de Roma ${ }^{131}$, às questões divinas e humanas: o mestre sabia que a ambição escolástica em sustentar racionalmente - i. e., no quadro da reflexão grega sobre o Ser - os dogmas da fé cristã alcançara com o tomismo seu maior esforço teórico, mas também chegara ao seu esgotamento e ao impasse e se perdia em uma selva de silogismos e disputas acadêmicas já há cerca de dois séculos desde que, como compreendemos hoje, Guilherme d’Ockham finalmente extraira todas as conseqüências do aristotelismo averroista ao apresentar uma incontornável nova definição de certeza científica $^{132}$.

Na verdade, Erasmo se manifesta em geral favoravelmente a Tomás de Aquino que com outros realistas - realium - defensores em diferentes graus da realidade dos universais nos indivíduos, integram, à época, a já chamada via antiqua em oposição à via moderna inaugurada pelo empirismo radical de Ockham que não reconhece como válida para cada indivíduo qualquer proposição que não seja imediatamente evidente ou deduzida de uma preposição imediatamente evidente para os sentidos. Mas, para além das especulações metafísicas, parece que o que está em jogo para Erasmo é o seguinte: a via antiqua é solidária, digamos próxima, da noção de um Deus que não age livremente, mas antes por uma necessidade natural e por uma certa propriedade que a sua bondade possui de difundir-se por ela mesma; esta noção está visivelmente em linha, é herdeira do necessitarismo grego e do platonismo radical das teologias naturais que confundem o Deus

\footnotetext{
${ }^{130}$ Gilson, Étienne; op. cit., p. 724. Esta consideração sempre foi uma unaminidade entre os humanistas: "Petrarca viu muito bem e muitas vezes denunciou o perigo para a fé cristã que resultava desta cultura puramente dialética, sobretudo a partir do momento em que, por sua influencia, se abandonava o estudo dos Padres”.

131 Lembremos de Clemente de Alexandria, Agostinho, Boécio e Abelardo, por exemplo, nomes que atravessam quase mil anos e precedem o escolasticismo.

${ }^{132}$ Gilson, Étienne, op. cit., p. 640. "O estudo de Guillherme de Ockham permite constatar um fato histórico de importância capital e que sempre se desconhece, que a crítica interna levantada contra ela mesma, por aquilo que se chama por um nome vago demais a filosofia escolástica, provocou a ruína desta antes mesmo que a filosofia dita moderna pudesse se constituir.” Também é necessário lembrar que Guilherme de Ockham foi um monge franciscano.
} 
cristão com o Bem concebido mais ou menos como uma Natureza (Bonum diffusivum) ${ }^{133}$. Já a via moderna, além de separar definitivamente no Ocidente os campos da fé e da razão, ao suprimir radicalmente as essências e os arquétipos universais não deixa nenhuma barreira que possa conter o arbitrário do poder divino e então todas as leis morais dependem apenas da pura e simples vontade de Deus que é livre para, a qualquer momento, perder os inocentes e salvar os culpáveis; ao Deus que pode ser pensado pelo filósofo se contrapõe o Deus completamente livre das sagradas escrituras e se este Deus não é uma natureza, mas uma liberdade, então toda questão ao seu respeito não comporta senão o imprevisível $^{134}$.

No entanto, Erasmo se afasta de um excesso de confiança ${ }^{135}$ na idéia de necessidade lógica aplicada à noção de Deus que os escolásticos da via antiqua freqüentemente empregavam para pretensamente explicar e compreender a ação divina julgando-se até mesmo sabedores dos segredos e vontades de Deus. Provavelmente Erasmo deve ter concordado com um certo ockhamismo das lições do antigo chanceler da universidade de Paris, Jean Gerson ${ }^{136}$, que em seu De concordia metaphysicae cum logica de 1426 apontara como o mal do século XIV o querer tratar da lógica a partir da posição de metafísico e da metafísica a partir daquela de estudioso da lógica ${ }^{137}$ e ainda antes, em Contra vanam curiositatem in negotio fidei de 1402, já afirmara que pouco se pode conhecer de Deus, apenas com o uso da razão natural, além do que já é revelado pela idéias inatas de que Deus é um ser tal que não se pode conceber um maior: as essências não são

\footnotetext{
133 Idem, p. 715.

134 Idem, p. 652. Mas o comentador já no início de sua introdução nas pp. 9 e 10 resume qual é a contradição teórica que atravessará todo o Medievo e se tornará visível apenas nas últimas conseqüências do esforço escolástico em justificar a fé pela razão: “(...) influenciados pela religião grega, os filósofos gregos são os filósofos da necessidade, ao passo que os filósofos influenciados pela religião cristã serão os filósofos da liberdade. Assim, desde as origens desta história, o desenlace de seu episódio central já estava decidido pela natureza mesmo das forças que a deviam criar. Este momento crítico se dará por volta do século XIII quando o mundo ocidental deverá escolher entre o necessitarismo grego de Averroes e uma metafísica da liberdade divina”.

${ }^{135} \mathrm{O}$ pensamento de Erasmo parece freqüentemente ser melhor compreendido a partir da consideração de que é sempre necessário buscar a correta nuance - distinguere semper - mesmo dos conceitos recebidos da tradição.

${ }^{136}$ Coletânea R. Laffont. Vide tábua cronológica na p. XXVI. Já em 1495, Erasmo com 28 anos se dirige à Paris pela primeira vez para freqüentar a famosa Universidade. Gilson em op. cit. p. 712, informa que Jean Gerson faleceu em 1429 e foi chanceler da Universidade de Paris desde 1395 deixando discípulos e várias obras.

${ }^{137}$ Gilson, Étienne, op. cit., p. 713.
} 
que abstrações, resultado de análise que o pensamento faz a fim de distinguir seus objetos; torná-los coisas é transformar a lógica em metafísica e em breve em teologia. O erro de todos os realistas é simples: consiste em crer que tudo que o intelecto conhece universal, abstrata e separadamente existe universal, abstrata e separadamente nas coisas e em Deus $^{138}$.

Erasmo sabia que o fracasso em manter unidas a fé e a razão só poderia continuar a conduzir ao ambíguo fideísmo ${ }^{139}$ de filósofos, e demais esclarecidos sobre as aporias que resultam da aplicação da dialética às questões teológicas, ou ao cego radicalismo na fé calcada unicamente na Revelação cristã - com a inevitável ruptura da unidade da verdade entre cristãos e pagãos e a conseqüente anatematização de filósofos, escritores e poetas clássicos e o possível mergulho em novo ciclo de barbárie, talvez confirmado aos seus olhos pela violência associada à Reforma - ou então, como foi sua opção, pela substituição deste já velho esforço escolástico em impor a dialética como serva da teologia - philosophia ancilla theologia ${ }^{140}$ - pelo frescor do entendimento petrarquiano de que a fé deveria ser servida pela filosofia enquanto tradição retórica - eloquentia ancilla theologia ${ }^{141}$ - na busca da preservação da unidade entre a fé cristã e as invenções pagãs, como já haviam feito os Pais da Igreja, e na busca da total recuperação renascentista do classicismo.

Como resultado, podemos compreender que Erasmo integra o esforço intelectual constituído pela filosofia enquanto retórica no seu mais alto registro que é a reflexão sobre os problemas fundamentais do Homem e seu Bem, esforço intelectual continuador da discussão, nos termos estabelecidos pelos textos gregos, que voltou a

\footnotetext{
138 Idem, p. 716.

139 Idem, p. 639. “(...) de outra parte, os averroísta latinos se multiplicavam apesar das condenações que sua doutrina recebera, e suas alusões transparentes quase não permitiam de duvidar de seu fundamental ateísmo”.

${ }^{140}$ Observamos por vezes Erasmo usar a palavra "eloqüência”, em um registro elevado, no lugar de "retórica" e que os escoláticos chamavam de "filosofia” o que Erasmo chamava de "dialética” e chamamos com Kant apenas de "metafísica” ou atualmente de filosofia enquanto reflexão sobre o Ser, i. e., “ontologia”.

${ }^{141}$ Gilson, Étienne; op. cit., p. 751. Comentando a posição de Nicolas de Clamanges quando do retorno das belas letras à França na Renascença, Gilson nos ensina que este autor propõe que se lembre que Agostinho já designara a eloqüência como serva da Sabedoria Divina, lhe atribuindo com isto muita honra, pois esta Sabedoria possui muitas servas e nenhuma, tão necessária, a segue assim de perto e a serve com tanta utilidade quanto a eloqüência - sed unum tamem eloquentiam singulariter et prae caeteris ancilam habere dicit, individua sibi societatem conjunctam, quia illius ministerio et maxime indiget et maxime utitur (...).
} 
florescer em uma época em que a filosofia como metafísica esgotava seus recursos para manter a unidade da verdade entre a fé e a razão - e no limite, por desdobramento, entre a doutrina cristã e toda a sabedoria pagã - e fez confluir o cristianismo e o classicismo enfrentando os obstáculos teóricos para a ampla aceitação e recepção de todo patrimônio literário clássico.

No entanto, além desta breve discussão a partir da história da filosofia para a melhor compreensão e visibilidade de sua legítima e concreta tradição retórica, seria ainda útil uma consideração sobre a dificuldade que o senso comum pode invocar quanto ao valor intrínseco da retórica como criadora de positivo conhecimento filosófico e instrumental crítico. Ora, comecemos por evidenciar as possibilidades da retórica como crítica filosófica: os próprios adversários de Erasmo acusaram o potencial destruidor que sua retórica, tão aberta às invenções pagãs, poderia trazer para a fé cristã e entreviram, talvez, que assim como os argumentos averroistas da dupla verdade pela separação respeitosa entre o campo da fé e aquele da razão poderiam esconder um fundo ateísmo, também a prática retórica - favorecendo a explicação racional pelas causas e não pelo maravilhoso - levaria inconfessadamente a uma sorte de religião natural, esvasiada de tudo o que pertence ao mundo místico e mesmo à própria dissolução da idéia de Deus.

Isto jamais foi defendido por Erasmo; ele jamais se apresentou como ockhamista nem como integrante de qualquer corrente filosófica. Em que pese verossimilhanças e a legítima suspeita de um certo ceticismo em seus escritos, na sua reserva frente a questões religiosas cruciais, no seu misticismo intelectualista que também pode ser entendido como um anti-misticismo, não é notório ou provável que o autor tenha conhecido os poderosos argumentos pirrônicos, e mesmo seus largos elogios aos filósofos acadêmicos, como os mais “modestos” - verecundior ${ }^{142}$ - não encobrem sua patente confiança na existência de uma verdade única e acessível ao homem em algum grau. Neste sentido é preciso reconhecer no autor um cristão que, mesmo possuindo uma estranha impaciência para com os dogmas e práticas da fé, ainda pode ser considerado um

\footnotetext{
${ }^{142}$ Desiderii Erasmi, LB, X, op. cit., 1717, C. “(...) estes [acadêmicos] são tão mais modestos quanto sábios -
} hic tanto esset caeteris verecundior, quanto sapientior. Leia-se hoje, “modestos” no ímpeto dogmático. 
metafísico em sua natureza mais profunda como escritor incansável na crença em um progresso geral em direção à verdade que em algum sentido é cristã.

Mas ocorre que sua conviç̧ão metafísica não é aquela fundada nas elaborações dialéticas de Platão, muito menos naquelas de Aristóteles, exibidas com orgulho intelectual pelos escolásticos e sim, talves, em fonte imediatamente anterior, com muito menor número de proposições, diríamos hoje, à priori, pois a metafísica erasmiana a par de seu nominal, discutível ou incontornável confessionalismo para a época - de tão enxuta, parece vincular-se apenas à socrática confiança na realidade em si de um fim, de um Bem, de uma perfeição última para o homem encontrável apenas em um esforço coletivo e metódico para a superação da ignorância. Esta é uma suposição que se baseia obviamente na tradição inaugurada entre outros por Aristóteles - que separa o legado platônico de seu mestre apontando o discípulo como verdadeiro responsável pela teoria das idéias - e na intuição de que o autor, conhecedor de inúmeros diálogos platônicos, preferiu provalvemente, com a sua notória e natural prevenção contra as afirmações peremptórias, ater-se mais ao método do mestre que ao resultado obtido pelo discípulo; método, aliás, tão fecundo quanto são as escolas dissidentes que reivindicam o prestígio da mesma fonte. $\mathrm{O}$ próprio Erasmo lamenta a existência de termos separatistas tais como platonismo, aristotelismo, epicurismo, estoicismo etc vendo neles mais a obstinação tribal, que também impera entre as diferentes ordens religiosas, do que diferenças lógicas irredutíveis; estas seriam sutilezas superáveis no confronto retórico em que o amor pelas palavras não fosse maior que aquele pela verdade que não sabe ser senão única.

Fato é que a maiêutica socrática que supõe um sabedor ou um pesquisador e alguém que pensa que sabe ou quer saber, não é contraditória com o que posteriormente Aristóteles chamou de “retórica” e que deveria servir à filosofia. Estes filósofos-retóricos se diferenciam claramente dos sofistas na medida em que nos próprios diálogos platônicos seu mestre se apresentava freqüentemente sem resposta para os problemas que propunha e não raramente estes restaram inconclusos, fato inaceitável para aqueles sabedores profissionais. E certamente não deve ter sido o Sócrates platônico, ocasionalmente também dogmático e duramente dialético, como os escolásticos que 
Erasmo tanto criticou, que mereceu deste sua famosa expressão "Sancte Socrate ora pro nobis”, mas um Sócrates indagador ${ }^{143}$, interessado em ouvir, - sed inquirentis potius, quam praecipientis oratio $^{144}$ - recusando o papel de mestre e se apresentando como o melhor dos cidadãos pelo serviço que prestava a Deus.

Assim, temos um autor mais próximo de um Sócrates ardente amante da verdade que de um confiante e idiossincrático Platão, mais próximo de uma mínima metafísica que quase se reduz a uma antropologia à qual se associa secundariamente uma teoria da história, de resto comum a quase todos os renascentistas, que de uma metafísica que atribui toda realidade ao mundo invisível; mais próximo de um mestre que aparentemente confia mais na verdade que resulta do concurso das opiniões ${ }^{145}$ que são enfim invenções, conhecimento que o homem encontra - invenit - e tira de si mesmo, que da dedução lógica à posteriori, a partir de pressupostos sobre a realidade da natureza do que é.

Mas sobre este ponto é preciso superar ainda um equívoco freqüente sobre a diferença entre a metafísica apoiada apenas pela dialética aplicada à natureza enquanto existência de tudo que é, e a retórica apoiada pela dialética e pela eloqüência e aplicada aos assuntos puramente humanos, pois se compreende e se aceita com facilidade

\footnotetext{
${ }^{143}$ Mondolfo, Rodolfo, op. cit., p. 63. “(...) ainda na conclusão negativa de seu não saber, a dialética socrática contém um elemento essencial positivo e construtivo, que é a confiança incondicional no valor da razão, e uma proclamação solene dos seus direitos; [assim] pode entender-se de maneira mais adequada se se considerar a orientação característica do método socrático de investigação que substitui o logos pelo diálogo”. ${ }^{144}$ Desiderii Erasmi, LB, X, op. cit., p. 1715 C. Subtítulo "A ignorância é a mãe da soberba e a erudição, ao contrário, da modéstia” - Ignorantiam esse svperbia matrem, ervditionem contra modestiam parere.

${ }^{145}$ De Bujanda, J. M, op. cit., p. 25. "Ele [Erasmo] é profundamente ligado a uma Igreja que há quinze séculos descobre continuamene a mensagem de seu fundador, a uma Igreja que, mais que um organismo de ortodoxia, é uma comunidade de crentes reunidos na fé no amor do Cristo, a uma Igreja que dá lugar ao diálogo e às diferentes teologias, a uma Igreja que acha sua norma de fé no consenso do povo cristão”. Mondolfo também trata da verdade em Sócrates como resultado do acordo entre as subjetividades esclarecendo que "No logos individual os sofistas haviam assinalado o caráter de subjetividade e relatividade; Sócrates, em compensação (...) quer encontrar na mesma consciência do sujeito não só a particularidade relativa, mas também a universalidade absoluta. Como? Por meio da possibilidade do acordo com as outras consciências (...) mediante o exercício da pesquisa em comum.” e lembra uma passagem do Górgias (487e): "Quando na discussão vieres a concordar comigo - disse Sócrates a Cálicles - podemos considerar aquilo em que os dois concordamos e não precisaremos procurar outras pedras de toque (...) A nossa concordância darnos-á a verdade perfeita” e acrescenta que “A satisfação da exigência heraclítea do logos comum, segundo Sócrates, pode conseguir-se no diálogo, isto é, mediante a cooperação, a solidariedade investigante dos diferentes assuntos, que na coincidência recíproca possam encontrar o subjetivo que é, também objetivo, o individual que é também universal” (op. cit., pp. 63 e 64).
} 
que os conhecimentos da primeira são seguros e inquestionáveis, adjetivados como “conhecimentos lógicos” porque deduzidos conforme o princípio de identidade e porque explicitam verdades contidas por pressupostos evidentes aos sentidos ou à razão; desse modo, porque todo homem é mortal, o homem Sócrates é mortal. Em desvantagem com relação a estes, os conhecimentos retóricos, são tomados modernamente por algo quase inferior à mera opinião - desde que a opinião se assume como parcial e a retórica pode usar a eloqüência para enganar passando-se por imparcial - ou no máximo confundida com literatura. Mas se esquece que os conhecimentos retóricos são tão lógicos quanto os conhecimentos dialéticos na medida em que também obedecem ao princípio de identidade e não aceitam o contraditório; desse modo, porque se afirma que Sócrates é filósofo, não se afirma que Sócrates não seja filósofo. O que se deve entender com a ajuda de Kant sobre este confronto de método é que o conhecimento dialético aplicado ao Ser é analítico, opera por desdobramento, i. e., A possui A1, A2 e A3, etc; e o retórico aplicado às questões do homem é sintético, opera por uma vinculação que tão só e somente obedece ao arbítrio humano e à sua capacidade de invenção, e. g., quando afirma A é igual a B.

É importante perceber que este entendimento inverte a relação de desvantagem, pois hoje mostra claramente que os conhecimentos analíticos fecham-se sobre categorias do pensamento cuja capacidade de realmente corresponder perfeitamente a uma realidade em si tem sido sucessivamente questionada pela história da filosofia desde que no final do medievo Ockham apresentou críticas intransponíveis a toda forma de realismo dos universais, enquanto se vê diferentemente, desde a Renascença - mas não com estas palavras - que a invenção humana, possibilitada pelo discurso retórico, é ao menos criador de sentido, de significado, pois mesmo quando escolhe um simples adjetivo para qualquer substantivo faz uma síntese inovadora e com isto propõe toda uma realidade para o entendimento das coisas humanas. É neste sentido que se torna emocionante a expressão de desolação de um Lourenzo Valla ao constatar a ruína a que foi reduzida toda a coleção de preciosas descobertas - inventiones - conhecimentos irrepetíveis, scientia do homem sobre si mesmo que compõe toda uma eruditio cuja perda definitiva é uma tragédia clades - tão mais insuportável de ser pensada quanto mais genial percebemos ser o que sobreviveu - subsistit - aos pedaços. 
Já Francis Bacon no início do XVII havia comparado os dialéticos escolástico com as aranhas que tiram de si mesmas o material - i. e., sua razão - com que tecem a rede na qual se sustentam ${ }^{146}$, mas parece que foi injusto ao acusar os retóricos renascentistas, de simplesmente reproduzir conhecimentos enciclopédicos sob o peso sufocante da tradição. Talvez o chanceler inglês não se referisse a Erasmo e aos retóricos que na tradição socrática, pré-platônica e mesmo sofística, indagavam sobre os assuntos humanos colhendo nos textos desta tradição antes inspiração e advertência contra certas ingenuidades da ignorância que soluções acabadas. Ou talvez se esquecesse que Cícero, no seu De inventione ${ }^{147}$, para explicar sua arte narrou a história do célebre pintor Zeuxis de Heracléia que, chamado para decorar o templo da deusa Juno na cidade de Crotona, quis pintar Helena para reter em uma imagem única o modelo perfeito da beleza feminina e para isto pediu que lhe fossem trazidas as mais belas mulheres da cidade para de cada uma copiar o traço mais bonito. Nesta imagem da retórica, brilha a evidência de que cabe ao autor escolher suas fontes, comparando-as na escolha dos argumentos mais fortes que possuam para compor um todo novo que é de longe, e em um sentido misterioso, superior à simples soma das partes.

Então, ao integrar o esforço intelectual constituído pela filosofia enquanto retórica no seu mais alto registro, Erasmo se dedica a superar o problema cuja solução tornou-se imperativa para a sua época como foi a destruição de Cartago para os romanos: a atualização e conclusão do trabalho iniciado pelos Pais da Igreja para a harmonização teórica entre a doutrina cristã e o impressionante e desconcertante legado greco-romano cujo resgate parcial - então se completando - foi suficiente para trazer à luz testemunhos de uma tal magnificência que ameaçava o período com o risco de uma crise ideológica, ruptura de valores, cisão da cultura e enfraquecimento da autoridade da Igreja com o conseqüente esfacelamento da ordem política conhecida. Assim, o autor se dedica à premente e inadiável harmonização entre o Homem da revelação cristã e um renascente Homem pagão, agora recuperado por inteiro como rico, autônomo e inquieto artífice de

\footnotetext{
146 Bacon, Francis; Novum Organum, São Paulo, Ed. Abril, Col. Os Pensadores, 1973, p. 69. Vide aforismo 95.

${ }^{147}$ Cícero, op. cit., p. 130. “(...) então, [para escrevermos] de todos os escritores, extraímos os preceitos que pareciam os mais justos e os reunimos em um só lugar" - sed omnibus unum in locum coactis scriptoribus quod quisque commodissime praecipere videbatur, excerpsimus.
} 
cultura; compatibilização que exige a crítica tanto do Homem pagão quanto do cristão, crítica possível apenas a partir da suposição de uma verdade que ambos compartilham e da qual se desviam apenas por não conhecê-la perfeitamente; verdade que ambos possuem em graus diferentes mas graus de uma verdade única que os faz então iguais na unidade da verdade. Esta é a tarefa a que se propôs quem, possuindo um sentido agudo da influência que suas palavras conquistaram em toda a Europa, buscou, tal qual um novo Janos, olhar simultaneamente para o Homem cristão e para o Homem greco-romano e enxergar, em grande medida, o Homem nosso comtemporâneo. 


\section{CAPÍTULO II}

\section{ERASMO E A CRISE DA UNIDADE DA VERDADE}

A maior fissura da unidade da verdade no Renascimento - que em termos sociológicos talvez possa ser entendida como colapso de uma sólida identidade cultural pan-européia construída e mantida pela Igreja por um período que à época já completava 1000 anos - origina-se no baixo medievo e se abisma com a recuperação da cultura clássica pelo Ocidente, mas tem seu epicentro na discussão filosófico-teológica ${ }^{148}$ em que ocorre o gradual descolamento entre fé e razão e assim, toda uma cultura tem seu tendão de Aquiles no esgarçamento da compatibilidade entre estas duas formas de conhecimento. Portanto, a dissolução de uma visão integral do mundo é prenunciada por uma dificuldade teórica que compromete a basilar confiança na unidade da verdade.

Durante o medievo a harmonia entre as duas havia sido solidificada e garantida especialmente por Agostinho, o mais importante e complexo dos Padres Latinos da Igreja Ocidental a criar uma síntese entre elementos antigos e cristãos, que não foi apenas um excelente retórico e muito culto que recorreu ao método alegórico para justificar o estudo dos poetas e prosistas romanos, mas também filósofo e teólogo erudito que legou para a posteridade uma doutrina religiosa enriquecida por idéias teológicas da maior complexidade como a cidade de Deus, o pecado original, a graça e a predestinação, assim como conceitos filosóficos de origem grega e latina, e.g., as formas eternas na mente divina, a incorporeidade e imortalidade da alma ${ }^{149}$. Durante a alta Idade Média a influência de Agostinho foi sentida - além do campo da teologia propriamente dita que por séculos foi o conhecimento superior entre os remanescentes de um Sacro Império - na educação no pensamento político e no século XI e XII, com o surgimento das universidades e o escolasticismo, suas obras foram a inspiração primordial, pois representavam o conjunto

\footnotetext{
${ }^{148}$ É conveniente insistir que neste período o adjetivo "filosófico" significava mais precisamente "dialético" e se aplicava ao esforço dos pensadores da Igreja em assimilar a tradição grega de reflexão sobre o Ser à doutrina cristã.

${ }^{149}$ Kristeller, P. O., op. cit., p. 98.
} 
mais sólido de idéias teológico-filosóficas existentes em latim e era com toda justiça que se chamava de "agostinianos" os primeiros escolásticos. Com o advento do aristotelismo, o agostinismo continuou entre estes como importante corrente secundária no meio universitário ao mesmo tempo em que a teologia dos místicos e a ampla corrente de literatura religiosa popular se mantiveram fiéis ao espírito de Agostinho. Sua presença difusa na Renascença possui capilaridade ao ponto deste pensador cristão ser considerado pelos dirigentes da Devotio Moderna nos Países Baixos a máxima autoridade depois da Bíblia $^{150}$ e ser o autor favorito que Petrarca lerá em sua cópia manuscrita das Confissões ao atingir o cume na sua famosa ascensão ao monte Ventoux ${ }^{151}$.

O fideísmo ${ }^{152}$ que se apóia nos escritos de Agostinho não é absolutamente favorável aos domínios separados da fé e da razão, mas se coloca em uma posição entre a confirmação da fé pela razão e a retirada gradativa da razão do campo da fé em que é preciso decidir se é descartar a razão o ato de provar sua insuficiência com o emprego da própria razão. Senão, é preciso lembrar de alguns argumentos agostinianos: pelo conhecimento das coisas eternas e sua contemplação, a sabedoria distingue-se do conhecimento científico de tudo aquilo que se insere na experiência do tempo e do espaço contido no viver humano como uma cognitio historica. Este conhecimento deve ser útil e contribuir para a sabedoria, mas é a fé que é imprescindível para se crer no que não se vê; ela é uma realidade do coração e embora semelhante e comum a todos os crentes, é diferente em grau para cada um. Sua necessidade é manifesta se considera-se o universal

\footnotetext{
${ }^{150}$ Idem, pp. 79 e 105.

${ }^{151}$ Cassirer, Kristeller e Randall Jr., op. cit.., p. 36. Mas Kristeller em op. cit., p. 106, faz a ressalva de que foi o Agostinho das Confissões que com eloquência expressava seus sentimentos e experiências que impressionou Petrarca e os humanistas que se seguiram e não o posterior teólogo dogmático. Também Gilson em op. cit., pp. 722 e 723 nos informa que a partir do dia em que Petrarca teve em Agostinho a garantia de que um cristão podia amar Platão, Cícero e Virgílio ele encontrou seu equilíbrio e assim a eloqüência das Confessiones não podia fazer menos por converter Petrarca que aquela de Hortensius de Cícero havia feito para converter o próprio Agostinho.

${ }^{152}$ Popkin, Richard H., op. cit., p. 28. Acompanho este autor na sua definição de fideístas: “Ceux que je classe parmi les "fidéistes" doutent que nous puissions atteindre à la connaissance par des moyens rationnels si nous ne bénéficions pas de l'aide de quelques vérités fondamentales reposant sur la foi (c est-à-dire de vérités ne reposant pas sur la moindre preuve rationnele). Mais à frente, p. 30, este autor esclarece que sua definição corresponde a uma escolha terminológica mas também doutrinária, visto que o fideísmo foi condenado pelo catolicismo como heresia enquando o protestantismo afirma que o fideísmo é um elemento de base do cristianismo fundamental, elemento que se encontra nos escritos de Paulo e Agostinho, e confessa “Bien que j 'emploie plutôt le mot à la manière des protestants qu'à celle des catholiques, mon intention n'est certes pas de préjuger (...)”
} 
desejo humano de felicidade, pois o meio de obtê-la varia porque nem todos a conhecem e assim desejam o que não conhecem - sendo que pensam que a conhecem. Entre estes estão os epicuristas que confundem felicidade com prazer e consideram feliz quem vive como quer. Mas é grande desgraça querer o que não convém. Para se corrigir esta hipótese é necessário que não se queira o que seja mal e que percebamos, ao fazê-lo, que já possui algo bom quem tem vontade reta e deseja apenas as coisas justas. Assim, segue-se que a fé em Deus é imprescindível na vida mortal cheia de erros e tribulações visto que é impossível encontrar bens se não vierem de Deus, o supremo Bem que os olhos não vêm ${ }^{153}$.

Os filósofos estóicos entretanto instituem a felicidade como resultado de seus próprios esforços em querer apenas o que pode sua condição humana e mortal. Mas o mortal não quereria apenas o possível se pudesse escolher, e então o conselho de suportar com paciência o que não se quereria é conselho dado a um infeliz ao passo que se considera que se alguém é feliz, tudo o que deseja é possível para ele e certamente deseja conservar sua felicidade sendo imortal. É também inaceitável que outros filósofos, os acadêmicos, postulem que na vida feliz que todos desejam deve-se permanecer indiferente diante dela própria sem desejá-la ou recusá-la, pois se o fazem, não a amam e se não a amam, não é uma vida feliz. Assim, se não há dúvida que todos desejamos ser felizes, então desejamos a vida imortal e a grande dificuldade de saber se a natureza humana pode receber a felicidade eterna somente é resolvida pela fé que, sem os argumentos da razão, entrega-se à autoridade $\operatorname{divina}^{154}$.

E é justamente a fé que explica em uma única e mesma alma racional a distinção entre ciência e sabedoria e permite compreender como o conhecimento científico torna-se sabedoria: do ponto de vista da fé, a ciência atende simplesmente às necessidades práticas do homem no tempo e pode até mesmo tornar-se mera curiosidade sobre as coisas temporais quando incorre no interesse por si mesma, fazendo ciência pela ciência, escapando da sua tarefa mais urgente e ampla para o Homem que é a de favorecer o conhecimento das verdades eternas para tornar-se sabedoria. Mas também, do mesmo ponto

\footnotetext{
153 Agostinho, A Trindade, São Paulo, Paulus, 1995, p. 406.

154 Idem, pp. 402 a 413.
} 
de vista da fé, a ciência tem o dever de mostrar ao homem a insuficiência da razão para garantir a felicidade eterna - o que a torna força motriz da fé - e tem o dever de explicar aos ouvidos dos homens o que significam as palavras de fé que asseguram que a imortalidade está apoiada em um Cristo que ressuscitou dentre os mortos ${ }^{155}$.

De fato, a fé não é vazia ou apenas uma ação válida por si mesma; ela tem um objeto que é o Cristo de que trata o Evangelho e cujo significado lhe é explicado pela ciência como a maior graça entre todas as coisas acontecidas no tempo que foi o Homem ter-se unido a Deus em uma mesma pessoa. Desse modo a ciência explica o significado e a importância extrema de Cristo para o homem e a sabedoria vê nele a verdade eterna. Em resumo, é a ciência que explica por palavras à alma racional sua limitação na busca da felicidade e o significado da teologia cristã que favorece a fé que, então, como sabedoria, é o conhecimento das verdades eternas ainda no tempo, visto que depois do fim deste, a fé não será mais necessária ${ }^{156}$.

Mas pode-se falar em uma sabedoria do homem que equivale ao culto de Deus, à piedade ou mesmo à disciplina cujos sentidos se aproximam ao de ciência ou então de simples exercício, que no entanto são muito diferentes daquela sabedoria de Deus. E se tomarmos a sabedoria resumidamente como conhecimento das coisas divinas opondo-a à ciência como conhecimento das coisas humanas, deve-se ressaltar que esta tem muito de supérfluo e vã curiosidade, mas pode ser de grande ajuda para que os piedosos se defendam contra os ímpios e apartem-se do mal quando é composta propriamente por conhecimentos que geram, nutrem, defendam e fortaleçam a fé que conduz o homem à verdadeira felicidade que só pode ser conquistada pela vida eterna. Este serviço da ciência entendida como doutrina imprescindível ao surgimento na alma de uma trindade da recordação, visão e amor da fé tem, porém, uma finalidade no tempo: favorecer a sabedoria entendida como visão eterna de Deus. De fato, o Homem interior se apóia nesta trindade da fé que é temporal e aspira ainda aos bens eternos pois crê no que não vê e quando ver, a fé deixará de existir ${ }^{157}$.

\footnotetext{
${ }^{155}$ Idem, pp. 439 e 440.

156 Idem, p. 441.

${ }^{157}$ Idem, pp. 438 a 439.
} 
Este sólido fideísmo agostiniano que se apóia em um inalienável desejo de imortalidade ainda tem como lastro a descoberta lógica de um 'eu' interior desenvolvido talvez a partir de uma sugestão aristotélica ${ }^{158}$ : ao obedecer corretamente ao preceito délfico “conheça-te a ti mesmo", deixando de lado o que pensa ou imagina de si - nada acrescentando, portanto ao conhecimento de si que lhe seja exterior ou imagem - a alma sabe enfim que ela própria existe e vive e entende, pois é inegável que quem entende está vivo e quem está vivo é porque existe e quem duvida disto entende que duvida, quem duvida vive para poder duvidar e ainda que duvide de outras coisas não deve duvidar da existência de sua duvida, então quem duvida ainda assim entende, vive e existe. Erram portanto os que tomam a alma por substância em que a inteligência seria como um acidente no sujeito ou tomam a alma como o próprio acidente em um corpo, pois quando a alma busca conhecer-se não conhece a si mesma como um corpo, mas como uma presença interior que sabe com certeza que entende, vive e existe ${ }^{159}$.

Esta grade conceitual desqualifica a razão à maneira dos céticos acadêmicos, pois apresenta a ciência atendendo simplesmente às necessidades práticas do homem no tempo em contraste com a sabedoria, única capaz de oferecer o conhecimento das verdades eternas - mesmo que empregando simultaneamente um poderoso racionalismo para identificar o que não seja passível de dúvida e possa ser colocado à disposição para servir à fé - atravessa invicta todo o medievo até que, na Renascença, a plena recuperação do esparso ceticismo acadêmico e a divulgação e compreensão dos sistemáticos, sofisticados e invencíveis argumentos do ceticismo pirrônico instaurassem uma verdadeira crise na capacidade da razão alcançar qualquer verdade favorável à fé: assim como os Padres da Igreja haviam enfrentado o problema de absorver e amalgamar a substância da literatura clássica e das filosofias antigas, problema recolocado no final da Idade Média com a necessidade de se reconciliar a filosofia aristotélica com a teologia cristã, o Renascimento especialmente entre o século XV e XVI, com a variedade das fontes

\footnotetext{
${ }^{158}$ Hadot, P.; “L’image de la Trinité dans l’âme chez Victorinus et chez saint Augustin”, Studia Patristica VI - Papers presented to the Third International Conference on Patristic Studies held at Christ Church, London, 1959, Berlin, Akademie, Parte IV, 1962, pp. 409-442. Há uma importante semelhança entre a proposição agostiniana e a instigante meditação aristotélica não esquecida pelos neoplatônicos: na Ética a Nicômaco o autor insiste na identidade entre vida e pensamento, entre a existência humana e a consciência de viver e pensar.

${ }^{159}$ Agostinho, op. cit. pp. 325 a 333.
} 
novas e das opiniões e posições antigas somadas às modernas, torna incontornável para muitos pensadores a questão de como dar unidade a essa repentina e restaurada diversidade de verdades possíveis ${ }^{160}$.

Entre as soluções prontas herdadas da Antigüidade havia várias formas de ceticismo plenamente desenvolvidas além do ceticismo acadêmico - corrente principal do pensamento cético que prevê para toda proposição filosófica a possibilidade de uma proposição contrária negando assim que seja possível uma verdade - conhecida graças aos escritos de Cícero e de integrantes do chamado ecletismo que dominava entre os estóicos e os platônicos médios; também a partir de $1562^{161}$ tornou-se amplamente disponível o ceticismo pirrônico com a primeira impressão das Hipotipóses Pirronianas, que diferentemente do ceticismo acadêmico, suspende o juízo inclusive sobre a questão da possibilidade da verdade, não a negando ou afirmando. Em um sentido diferente do ceticismo, havia escritos neoplatônicos e alguns aristotélicos que proporcionaram modelos para se intentar uma síntese filosófica que abarcasse tudo que fosse válido no pensamento antigo, rechaçando simultaneamente seus erros, além de um amplo número de argumentos herdados do pensamento medieval a propósito da relação entre fé e razão e entre filosofia e teologia que podem ser organizados da seguinte maneira: harmonia entre fé e razão ou a confirmação da fé pela razão na linha de Agostinho e Tomás de Aquino; a retirada gradativa da razão do campo da fé e a tendência a fundamentar a doutrina teológica na fé e na autoridade como se nota nas escolas de Duns Scott e de Guilherme de Ockham e finalmente, na coexistência da fé e da razão que concede à fé uma validade superior, mas não o direito de intervir no domínio da razão, posição esta conhecida como “teoria da dupla verdade". ${ }^{162}$

Entre os aristotélicos, Pomponazzi, em seu famoso tratado sobre a imortalidade da alma diferencia cuidadosamente aquilo que é verdadeiro, indubitavelmente verdadeiro em si e que deve ser aceito como tal com base na fé e aquilo que pode ser provado dentro dos limites naturais de acordo com os ensinamentos de Aristóteles e conclui

\footnotetext{
${ }^{160}$ Kristeller, P. O., op. cit., p. 264.

161 Popkin, Richard H., op. cit., p. 52.

162 Idem, p. 265.
} 
que se deve aceitar a imortalidade da alma como um artigo de fé, pois não se pode demonstrá-la a partir de uma posição natural, i. e., aristotélica ${ }^{163}$. A agudeza e persistência com que Pomponazzi e outros pensadores apresentam os argumentos da razão fizeram com que este já em seu tempo fosse acusado de encobrir com sua teoria dualista uma incredulidade real ainda que secreta, mas de fato a contribuição do dualismo de Pomponazzi está no fato de defender a religião e a filosofia aristotélica afirmando que fé e razão reinam em domínios separados ${ }^{164}$.

Diferentemente, o platonismo, a principal escola clássica revificada pelo humanismo, fez no Renascimento contribuições sólidas para restabelecer uma harmonia entre religião e filosofia superando o dualismo dos aristotélicos e o impasse ou ecletismo probabilístico dos céticos e reconhecer que existe uma verdade universal totalizadora apreensível pela razão.

\footnotetext{
${ }^{163}$ Cassirer, Kristeller e Randall Jr., op. cit., p. 377. Os autores apresentam a obra De Immortalitate Animae de Pietro Pomponazzi onde se lê no capítulo $X V$, e último deste livro, o seguinte subtítulo "in which is affirmed the final conclusion in this matter, which in my opinion must be maintained as beyond doubt" e a seguinte conclusão: "For it seems to me that no natural reasons can be brought forth proving that the soul is immortal, and still less any proving that the soul is mortal, as very many scholars who hold it immortal declare. (...). Wherefore we shall say, as Plato said in the Laws that to be certain of anything, when many are in doubt, is for God alone, I think that this can be made certain only through God."

${ }^{164}$ Kristeller, P. O., op. cit., p. 267.
} 
Este ponto de vista está claramente expresso, e. g., na metafísica de Nícolas Cusano que afirma que cada doutrina humana é a expressão especial de uma verdade universal que não pode ser manifestada mediante nenhum enunciado particular ${ }^{165}$.

No mesmo sentido de uma verdade universal, Marsílio Ficino, dirigente da Academia Florentina insiste que há uma harmonia básica entre a filosofia platônica e a teologia cristã ao defender a imortalidade da alma que considera essencial para a religião e para a teologia. A filosofia e a religião são expressões diferentes de uma mesma verdade fundamental, como deixa claro Ficino já no título de sua obra principal Theologia Platonica, onde apresenta não apenas o judaísmo antigo como verdadeiro predecessor da doutrina cristã - como requer a ortodoxia - como ainda as demais religiões enquanto manifestação do desejo fundamental do homem por um único Deus verdadeiro entre as quais o cristianismo representa a espécie perfeita ${ }^{166}$. A propósito da história da filosofia, de

165 Nicolau de Cusa, A douta ignorância, Tradução, Prefácio, Introdução e Notas do Prof. Dr. Reinholdo Aloysio Ullmann, Porto Alegre, Edipucrs, 2002. Nicolau de Cusa pode ser visto como um precursor da conviç̧ão renascentista na unidade da verdade, no esforço de superação da diferenciação medieval (especialmente da escolástica que surge na baixa idade média) entre verdades da fé e verdades da razão apoiada e refletida pelo entendimento da natureza como hierarquia qualitativa de seres, como proposto por Aristóteles. Se no infinito tudo se encontra "concentrado" (complicatum) numa unidade e o universo representa o desdobramento (explicatum) do que se encontra na unidade (p. 27), a partir destes novos conceitos complicatio e explicatio Nicolau de Cusa proporá para a questão epistemológica que a verdade exata é incompreensível desde que a "quiditate" das coisas, que é a verdade dos seres, não é atingível em sua pureza e tem sido procurada por todos os filósofos, mas não foi encontrada por ninguém tal como ela é ”(p. 47) pois “visto ser evidente por si mesmo que não há proporção entre o finito e o infinito (...)” (p. 46), entre o explicatum e complicatum que contém tudo inclusive o contraditório (coincidentia oppositorum) e então o uno e o múltiplo ao mesmo tempo. Desta percepção, o autor chega à teologia negativa que tem como corolário a sentença “A não ser que acredites, não entenderás. A fé contém em si dobrada (complicans, do latim 'plicare', i. e., 'dobrar') todo o inteligível - Nisi credideritis, non intelligetis. Fides igitur est in se complicans omne intelligibile; (pp. 26 e 212). Para a questão ontológica, será proposto que o universo e o Homem são contrações (contractio) harmônicas da complicatio, representam a explicatio da complicatio do Absoluto (p. 29), i. e., tudo que está realizado em ato no contractum foi, de maneira igual, contido originalmente, virtualmente e potencialmente no complicatio (p. 27) e, conforme a ordem da natureza, se o todo sem pluralidade precedeu cada coisa e se o universo não existe senão contraidamente nas coisas, se segue que toda coisa existente em ato contrai o todo e chega-se ao corolário que afirma que "Tudo está em tudo” (p. 125), em contraste com a noção medieval de hierarquia dos seres.

${ }^{166}$ Cassirer, Kristeller e Randall Jr., op. cit., p. 201. De Marsilio Ficino são apresentadas as Five Questions concerning the Mind; nelas, contrariamente às mentes céticas ou atéias e defendendo a concepção platônica que julga divinamente inspirada - e a religião cristã, Ficino afirma a unidade e a universalidade da aspiração humana em buscar a verdade universal e o mais alto Bem que é Deus pois "Surely, the condition natural to our intellect is that it should inquire into the cause of each thing and, in turn, into the cause of the cause. For this reason the inquiry of the intellect never ceases until it finds that cause of which nothing is the cause but which is itself the cause of the causes. This cause is none other than the boundless God. Similarly, the desire of the will is not satisfied by any good, as long as we believe that there is yet another beyond it. Therefore, the will is satisfied only by that one good beyond which there is no further good. What can this good be except the boundless God?” 
maneira similar, Ficino considera que obras atribuídas a Hermes Trismegisto, Zoroastro, Orfeu e Pitágoras - que a erudição atual reconheceu como falsificações feitas no final da Antigüidade - são monumentos genuínos da sabedoria pagã antiga, tanto ocidental como oriental, que possuem afinidades doutrinárias com o platonismo e que seus autores foram predecessores e mestres de Platão. Segundo sua opinião, estes autores constituem uma tradição da filosofia e teologia pagãs tão antigas quanto a tradição hebréia e cristã que remontam em paralelo respectivamente a Mercúrio Trismegisto e a Moisés, seu contemporâneo. É notável em Ficino a disposição em absorver em sua síntese tantos autores quantos lhe seja possível, incluindo Aristóteles e seus comentadores ${ }^{167}$.

Indo muito mais além, na concepção de uma verdade universal, Giovanni Pico della Mirandola, amigo mais jovem e associado de Ficino, defende que os pensadores de todas as tradições filosóficas e religiosas têm parte nesta verdade e, dando relevo à idéia de liberdade, reivindica o amplo estudo de todos os pensadores do passado e das diferentes escolas convicto de que em todas as obras de diversos tempos, lugares e religiões há uma parte da verdade. Esta convicção é expressa diretamente pelas 900 teses que Pico preparou para defender em Roma e nas quais são reunidas idéias de escolásticos modernos e medievais, pensadores árabes e judeus, filósofos aristotélicos e neoplatônicos gregos, teólogos antigos como Pitágoras e Trismegisto e até cabalistas; a mesma firme intuição também é patente no discurso que Pico compôs para a discussão de suas teses e no qual trata na segunda parte da universalidade da verdade com igual eloqüência com que na

167 Kristeller, P. O., op. cit., pp. 272 e 273. 
primeira parte trata da dignidade do Homem ${ }^{168}$. Em 1487, depois da condenação de algumas de suas teses, Pico publica a sua Apologia em que diz "Não estando sujeito a nenhum homem, fui a todos os mestres de filosofia, investiguei todos os livros e conheci todas as escolas (...) Por esta razão desejei trazer diante do público as opiniões de todas as escolas (...) e não de uma só, pois busco que a luz da verdade (...) brilhe com mais força em nossas mentes graças à comparação de várias seitas e ao exame de filosofias variadas”. Mas diferentemente dos ecléticos que escolhem nos autores o que na ocasião lhes pareça certo, conveniente ou útil, Pico julga com os escolásticos que a obra de cada pensador é composta por um número de enunciados específicos, mas acrescenta que o certo ou o falso de qualquer deles não afeta os demais e que é preciso identificar o verdadeiro. Pico possui ainda confiança absoluta no valor do ensino e da originalidade, pois argumenta que ao combinarmos e voltarmos a combinar os pontos de vista dos pensadores anteriores em plena liberdade para rechaçar qualquer enunciado em particular lhes damos nova forma e síntese e nos preparamos para propor opiniões próprias novas e talvez mais válidas ${ }^{169}$.

Pertencendo à mesma escola de Ficino e Pico mas com muito menor fama, Agostinho Steuco, teólogo católico liberal de meados do século XVI, desenvolveu a

${ }^{168}$ Cassirer, Kristeller e Randall Jr., op. cit., pp. 242 e 244. É inesquecível a vertiginosa quantidade de referências colocada em movimento pelo menino prodígio da filosofia renascentista no seu mais famoso texto, On the Dignity of Man escrito aos 24 anos, na busca apaixonada por "reflexos da mente divina" em todos os autores, escolas, religiões e seitas: "Consider, in addition, that there is in each school something distinctive that is not common to the others. And now, to begin which the men of our faith, to whom philosophy came last: There is John Scotus something lively and subtle; in Thomas, sound and consistent; in Aegidius, terse and exact; in Francis, acute and penetrating; in Albert, venerable, copious, and grand; (...) Among the Arabs, there is in Averroes something stable and unshaken; (...) in Alfarabi, serious and thoughtful; in Avicenna, divine and Platonic. Among the Greeks, philosophy as a whole is certainly brilliant and above all chaste. With Simplicius it is rich and abundant; with Themistius, graceful and compendious; with Alexander, harmonious and learned; with Theophastus, weightily worked out; with Ammonius, smooth and ageeable. And if you turn your attention to the Platonists, to examine a few: in Porphyry you will rejoice in the abundance of his material and in the complexity of his religion; in Jamblichus you will revere an occult philosophy and the mysteries of the East. In Plotinus there is no isolated aspect you will admire; he shows himself admirable on every side. The toiling Platonists themselves scarcely understand him when he speaks divinely of things divine and, with learned obliquity of speech, far more than humanly of human things. I prefer to pass over the later Platonists: Proclus (...)Hermias, Damascius, Olympiodorus and several others, in all of whom there ever gleams that (...), that is, "the Divine", which is the distinctive mark of the Platonists. Add to this that any sect which assails the truer doctrines, and makes game of good causes by clever slander, strengthens rather than weakens the truth (...). This has been my reason for wishing to bring before the public the opinions not of a single school alone (which satisfied some I coul name) but rather of every school to the end that that light of truth Plato mentions in his Epistles through this comparision of several sects and this discussion of manifold philosophies might dawn more brightly on our minds, like the sun rising from the deep."

${ }^{169}$ Kristeller, P. O., op. cit., pp. 275 e 276. 
idéia de uma sabedoria que abarca toda a história do pensamento humano a qual chamou de Filosofia Perene, título também de sua obra que resume de um modo novo as aspirações daqueles filósofos e que exerceu uma atração contínua nos séculos seguintes. A filosofia perene que Steuco tinha em mente era o platonismo representado por Platão e por seus seguidores do passado e do presente e por seus supostos antecessores que no básico concordava com um certo número de pontos de vistas de Aristóteles e outros filósofos antigos e, sobretudo, com a teologia judia e cristã. O nome "Filosofia Perene" fez fortuna e foi adotado por muitos pensadores posteriores e esteve associada à suposição de uma verdade universal situada além de qualquer doutrina humana particular - que, no entanto, tem nela uma participação - e vinculada à síntese de cada elemento de verdade de pensadores antigos e da tradição com toda nova descoberta feita com recurso do pensamento ou da experiência. ${ }^{170}$

Segundo Kristeller, o problema da unidade da verdade surge em linhas menos precisas entre os humanistas desde que o exemplo de Cícero, seu autor favorito entre os antigos, os animava a tomar emprestadas idéias e orações de uma ampla variedade de pensadores antigos e adaptá-las com bastante flexibilidade ao pensamento e escritos próprios.

${ }^{170}$ Idem, p. 277. 
Também o ressurgimento do ceticismo acadêmico - preservado principalmente pelos escritos do grande orador ${ }^{171}$ - ao insistir corrosivamente que toda doutrina filosófica pode ser refutada, produzia simultaneamente o efeito edificador de proclamar a liberdade intelectual para além dos limites estreitos de uma única doutrina fixa e aprovar de modo eclético qualquer pensamento específico desde que admitido como provável ou útil mesmo que nunca certo ou demonstrável em sentido estrito, escolástico. Este ceticismo na Renascença fez aliança com um tipo de fideísmo como nos casos de G. Pico della Mirandola e Montaigne com precedentes em Agostinho ${ }^{172}$.

Contra o longo esforço unificador que atravessa o Medievo e a Renascença, foi M. Lutero que em 1519 abriu a caixa de Pandora ao contestar toda fundamentação filosófica e os critérios tradicionais do saber religioso dando início à crise cética que longe de se restringir à teologia se estendeu rapidamente às ciências da natureza e a todo o conjunto do saber humano. Em efeito, a partir da Disputa de Leipzig, a Reforma recusava o critério católico pelo qual a verdade de uma proposição religiosa era garantida pela sua compatibilidade com a tradição da Igreja, os Concílios e os Decretos dos Papas e adotava o critério radicalmente novo que atribuía o valor de verdade apenas àquilo que a consciência individual era obrigada a crer lendo a Escritura Sagrada ${ }^{173}$. Esta disputa essencial sobre o critério correto do saber religioso, conhecido como a "regra de fé", se desenvolvia no quadro de idéias e argumentos dos céticos gregos e - apesar dos esforços conscientes para superá-lo - exemplifica perfeitamente o clássico problema do “critério de verdade” proposto por estes: “para que possamos decidir uma controvérsia entre nós, é necessário que tenhamos em comum um critério de verdade. Mas a definição desse critério de verdade passa a constituir nova controvérsia que para ser decidida necessita de outro comum critério de verdade. Assim a disputa cai no que chamamos de círculo vicioso; e se

\footnotetext{
${ }^{171}$ Popkin, Richard H., op. cit., p. 51. De acordo com este especialista, o ceticismo da Antiguidade chega para os pensadores do Renascimento através de três fontes principais: as obras céticas de Cícero como Academica e De natura deorum, os resumos feitos por Diógenes Laercio em Vida, doutrina e sentenças de filósofos ilustres e as Hypotyposes de Sextus Empiricus; Popkin também nos informa que Charles Schmitt em seu livro Cicero Scepticus (La Haye, 1972) localiza em 1430 a primeira aparição da palavra latina Scepticus em uma tradução latina de Diógenes e que a primeira referência conhecida, até o presente, à leitura de Sextus data de uma carta de 1441.

${ }^{172}$ Kristeller, P. O., op. cit., pp. 270 e 271. De acordo com Popkin, op. cit., p. 24, Agostinho, malgré luimême, torna-se um grande divulgador dos argumentos céticos ao refutá-los no seu Contra Academicos.

${ }^{173}$ Popkin, Richard H., op. cit., pp. 34 e 35.
} 
nós não permitimos aos dogmáticos estabelecer uma regra de verdade através de uma suposição, obrigando os sempre a fundamentar cada critério de verdade através de outro e assim em seguida, os conduzimos a uma progressão ao infinito” ${ }^{\text {174 }}$. Neste conflito intelectual em que reformados e católicos reivindicarão a posse do correto critério que permite distinguir a verdadeira fé da falsa fé, ambos se acusarão reciprocamente de defenderem argumentos que levam ao ceticismo. A regra de fé dos reformados baseada na certeza subjetiva será denunciada pelos católicos por se aproximar do puro ceticismo em que todas as afirmações são simples opiniões que não podem ser provadas objetivamente e será acusada a dificuldade em se definir que livro contém a verdadeira Escritura e a pluralidade de suas possíveis interpretações. Mesmo a posterior elaboração calvinista do argumento da "persuasão interior" será refutada por se fundamentar em um círculo vicioso em que são persuadidos os escolhidos de Deus que por sua vez têm a garantia da autenticidade desta ação divina na certeza da persuasão interior.

Por sua vez, a Igreja Romana será acusada igualmente de induzir à dúvida absoluta e ao ceticismo pela maneira como pretende ter alcançado um saber objetivo fundamentando-o apenas na sua própria autoridade, autenticidade histórica e suposta infalibilidade. Aos olhos dos reformados, seguros do que julgavam sua nova e definitiva regra de fé baseada na certeza subjetiva, o dogmatismo intransigente da Igreja baseado simplesmente na tradição e na posição conservadora de que - frente à incapacidade humana de discernir com certeza o falso do verdadeiro diante de passagens obscuras da Bíblia e das possibilidades por vezes contraditórias de interpretá-las - devia-se acatar por circunspeção as decisões da Igreja que tradicionalmente se responsabilizava por estas questões ${ }^{175}$, produzia o efeito contrário de levar o fiel ao convencionalismo próximo da descrença e ao ceticismo e exasperava Lutero $^{176}$ que insistia na necessidade de certeza absoluta e

\footnotetext{
174 Sextus Empíricus, Liv II, cap IV citado por Popkin, R., op. cit., p. 35.

${ }^{175}$ Esta é basicamente a posição adotada por Erasmo em seu De libero Arbitrio em 1524.

${ }^{176}$ Lutero, M., De Servo Arbitrio, op. cit., pp. 39 e 40. Lutero busca advertir Erasmo: "Nada es entre los cristianos más conocido ni más usual que la aserción. Haz desaparecer las aserciones, y habrás hecho desaparecer el cristianismo. Más aún: el Espíritu Santo les es dado a los cristianos desde los cielos para que glorifiquem a Cristo y para que Cristo sea confesado hasta la muerte, a no ser que "declarar con firmeza" signifique aquí outra cosa que morir por causa de hacer confesión y aserción.”
} 
moralizava a questão afirmando que o cristão deve ser absolutamente seguro do que afirma ou não é cristão, pois ele não pode crer se duvida ${ }^{177}$.

A revolução intelectual deflagrada por este ataque ao conhecimento religioso fundado em uma autoridade tradicional tocou o problema epistemológico crucial da garantia do saber a partir, parece, unicamente de argumentos céticos dispersos em escritos de Cícero, Luciano, Diógenes Laércio e Santo Agostinho mantidos pela tradição. Estes autores, no quadro geral renascentista anterior à Reforma, já eram citados em críticas anti-racionalistas em defesa da fé por pensadores ligados à Igreja preocupados com uma certa inspiração pagã do humanismo e com a maneira com que alguns teólogos cristãos se submetiam à autoridade de Aristóteles. E durante o século XVI seus argumentos céticos continuarão inspirando crescente interesse e desconforto e provocando manifestações de escritores como Rabelais, Sébastien Castellion, H. C. Agrippa von Nettesheim, cardeais Adriano di Corneto e Jacopo Sadoleto, Guillaume Budé, Guy de Brués, Omer Talon, Pirre de la Rameé e do círculo de intelectuais conhecido como "Plêiade". Todos estes escritores ao que parece, tendo acesso apenas aos argumentos céticos transmitidos por Cícero e por Laércio, serão acusados de serem "Novos Acadêmicos”, mantendo a contínua afirmação de que a fé é respaldada pela razão, ou elaborarão um ceticismo moderado que aceite da razão uma verdade “razoável” ou ainda, mais freqüentemente, se renderão ao fideísmo, ou seja, à aceitação de que diante da dúvida sobre a capacidade da razão humana, o saber só é alcançável por intermédio da fé ${ }^{178}$.

No entanto, este debate considera argumentos céticos transmitidos literariamente, de maneira difusa, por vezes subsidiária e o interesse que estes autores lhes manifestam faz parecer que nenhum deles tenha ainda se detido em uma análise séria e tenha descoberto a verdadeira força e natureza do ceticismo da Antigüidade. Algo diferente

\footnotetext{
${ }^{177}$ Idem, p. 41. "Maldito empero el cristiano que carece de certidumbre y comprensión acerca de lo que se le prescribe! Pues, cómo podrá creer lo que no comprende? Supongo, en efecto, que en este contexto tú entiendes por "comprender" [assequi] que uno tome una cosa cabalmente por cierta, sin haberla puesto en dudas como suelen hacerlo los escépticos. Por outra parte, qué hay en toda cosa creada que hombre alguno pueda comprender, si “comprender" fuese "conocer y ver perfectamente”? Siendo así, no podría darse el caso de que alguien comprendiera una cosa y al mismo tiempo no comprendiera la outra; sino que, habiendo comprendido una, las habría comprendido todas, a saber, en Dios. Quien no comprende a éste, jamás comprenderá parte alguna de lo creado."

${ }^{178}$ Popkin, Richard H., op. cit., pp. de 56 a 70.
} 
aconteceu quando os escritos pirrônicos de Sextus Empíricus - discutidos pioneiramente mas sem conseqüências por Gian Francesco Picco della Mirandola em Examen Vanitatis Doctrinae Gentium de 1520 - foram definitivamente divulgados com a primeira impressão de Hipotiposes em 1562 ${ }^{179}$ : comparados a eles, os céticos acadêmicos parecerão dogmáticos negativos ${ }^{180}$ e a análise epistemológica cerrada e a apresentação sistemática de argumentos pirrônicos irresistíveis em termos claramente filosóficos agudizarão o mal estar intelectual da época que, alcançando a dúvida absoluta, pelo seu impacto, tornará definitiva a crise filosófico-teológica.

E foi Michel de Montaigne ${ }^{181}$ quem apresentou a imagem completa da posição dos céticos pirrônicos e suas ferramentas dialéticas na maneira mais adequada ao seu tempo talvez por compreender e explicitá-las melhor que os escritores anteriores. A

179 Idem, op. cit., p. 54.

180 Idem, p. 25. "Contrairement au scepticisme de l'Académie que le doute menait à une conclusion dogmatique de nature negative, le scepticisme pyrrhonien ne faisait aucune affirmation et se contentait de dire que le scepticisme offrait un purgatif qui éliminait tout, y compris le scepticisme."

${ }^{181}$ Cardoso, Sérgio. “O Homem, um Homem: do Humanismo renascentista a Michel de Montaigne” in Coletânea Imago. Neste artigo seu autor prefere ver em Montaigne uma certa oposição aos demais Humanistas: "Mas se evocamos estes traços do humanismo (lugares comuns da historiografia deste período), fazêmo-lo com uma intenção particular. Desejamos lembrar aqui um projeto de conhecimento inteiramente gestado no bojo deste vigoroso movimento cultural (implicado no seu distanciamento crítico em relação ao universo religioso dos medievais e solidário de seus hábitos intelectuais mais proeminentes: o gosto pelas letras da Antiguidade clássica, a importância e o alcance atribuído à “maneira” ou ao procedimento, a atenção à vida moral dos homens e ao presente), mas supreendentemente desvencilhado de suas ambições e crenças mais ativas - desde sua vibrante confiança na capacidade criadora da humanidade elevada a uma dignidade divina até o universalismo de sua pretensão educadora, atada, à crença na destinação do Homem à perfeição e na dócil disposição do mundo à atuação de suas artes e à exploração de seu conhecimento” ( pp. 4 e 5 ). No entanto, o autor propõe que este “desvencilhamento", aparentemente cético, não significa que Montaigne tome como seu tema o próprio ceticismo pirrônico, mas que este se torna o caminho que o conduz "da esfera genérica do público para o espaço íntimo e privado” ( p. 7 ) e a tomar-se a si mesmo como objeto de conhecimento “Assim, leitor, sou eu mesmo a matéria de meu livro (...)” ( p. 8 ) com o que “(...) passa a deter de si mesmo uma imagem mais definida: seja, enquanto nas sucessivas autorepresentações de cada instante, os traços da própria imagem aparecem mais nítidos (...) seja, enquanto tal imagem, deslizando e transformando-se, leva-o a reconhecer-se no fluxo mesmo desta 'passagem' ” (pp. 32 e 33 ) operando a inversão do credo renascentista no Homem como microcosmo: "O livro revela-se, dete modo, um retrato vivo (Curiosa inversão. A consciência um tanto arrogante que se pensou ela própria, ainda há pouco, o espelho vivo do mundo, confronta agora sua fragilidade ao ver-se acuada a buscar no mundo um espelho, também vivo, para a sua efetivação)” ( pp. 30 e 31). Paul Jacopin e Jacqueline Lagrée em op. cit. p. 4, aproximam Erasmo desta descrição nuançada de Montaigne ao também desvincularem-no dos lugares comuns da historiografia do período: “(...) la especificité de l’humanisme érasmien, humanisme érudit, chrétien, iréniste, qui contribuera certes fortement à la détermination de ce qu'on appellera l'humanisme tout court, alors même qu'il est bien étranger à certaines thèses les plus caractéristiques de ce qu'on a désormais coutume d'appeler l'humanisme, lesquelles renvoient à des positions ultérieures, telles que la confiance en l'homme, la foi dans le progrès historiques de l'humanité, l'éloge des Lumières, la vocation prométhéenne de l'homme, etc. 
ocasião surgiu quando este traduziu e comentou, através de sua Apologia de Raimond Sebond, provavelmente entre 1575 e 76, a obra do médico espanhol Raimond Sebond composta por dois livros, “O livro da Natureza” e “O livro das Criaturas”, impressa em 1485, que faz uma defesa original dos dogmas da Igreja: enquanto os fideístas deixam de lado a razão em prol da fé e teólogos a promovem com um racionalismo elementar e apelos sentimentais, este autor se dirige não aos teólogos e doutos, mas ao homem comum; o livro não supõe outros conhecimentos, mas ao contrário, trata de doutrina que prepara os homens para a verdade que lhe é útil, i. e., o conhecimento de si - que deve ser anterior a todas as outras doutrinas para abrir caminho para os outros conhecimentos - pois as ciências nada valem se o homem não se conhece a si mesmo e seus fins. A obra apresenta uma doutrina, pois ensina e quer mover o homem para a fé pretendendo mostrar-lhe toda a verdade a que pode ascender sobre si, por si mesmo e a partir da experiência, não de uma filosofia. Segundo Raimond Sebond, basta olhar para a natureza e observar a precedência do Homem na natureza em que tudo é feito para ele por um Deus que por isto deve ser amado; a natureza nos leva até Deus, mas se os pagãos não chegaram até ele sozinhos foi porque não tiveram um guia como Cristo para os cristãos pela graça. Bem, a teologia é uma disciplina do saber, mas não é necessária para a salvação religiosa, assim como ela não é a Revelação e sim sua explicação e nesse sentido é racionalista na medida em que incorpora todo saber humano disponível para a defesa da fé como fez a teologia escolástica que pretendeu com a lógica aristotélica explicar, servir e favorecer a fé. Já a teologia de Raimond Sebond quer justificar a fé na observação da natureza e com isto atualiza o discurso teológico com reflexões humanistas tais como aquelas sobre o Homem como microcosmo, superior aos animais, ser privilegiado, elo do mundo com Deus e obra perfeita deste ${ }^{182}$.

Mas Montaigne critica a pretensão da teologia ser um saber, pois não há sustentação humana possível para a fé e, ao contrário, é a fé que apóia os discursos humanos, principalmente quando estes discursos não falam da natureza, mas sobre o transcendente, como os argumentos escolásticos ou mesmo dos humanistas e filósofos renascentistas. Em conclusão para Montaigne, o valor da obra do médico espanhol está nas imagens que dão graça, relevo, brilho e assim são úteis quase como os luxuosos rituais que

${ }^{182}$ Conferência feita pelo Professor Doutor Sérgio Cardoso em 19 de maio de 2004 na Universidade São Judas Tadeu, São Paulo, SP. 
não garantem nada, como nenhuma teologia pode garantir. Portanto, na sua Apologia de Raimond Sebond Montaigne inverte surpreendentemente o argumento do teólogo e, fazendo a crítica à capacidade da razão dar suporte à fé, defende aparentemente o argumento fideísta contra toda a pretensão de conhecimento humano. No entanto se o Fideísmo é o melhor argumento lógico apresentado por Montaigne contra a Reforma ${ }^{183}$ que pretendia deter um conhecimento religioso seguro e certo - as novas bases pirrônicas apresentadas para este fideísmo têm agora um caráter tão invencível que negam à razão a possibilidade de qualquer afirmação positiva, tocam como nunca antes o fundo filosófico do problema da garantia de qualquer conhecimento humano, queimam a ponte para o conhecimento da natureza e, ao final, conduzindo à simples aceitação provisória da tradicional regra da fé católica ${ }^{184}$, resvalam a irreligião e provocam contra o autor a acusação de má fé ou mesmo de ateísmo. De fato, Montaigne ampliava a crise cética fazendo uma frágil e suspeita defesa da regra de fé católica no mesmo livro em que apresentava previamente um insuperável pirronismo que pelo seu vigor filosófico acabava por refutar também de maneira inédita toda possibilidade de ciência da natureza no sentido aristotélico $^{185}$.

Depois que Montaigne apresentou em termos filosóficos definitivos toda a série de problemas quanto à confiabilidade do saber fundado sobre os sentidos, quanto ao critério do saber racional, à capacidade de conhecermos outra coisa que aparências e mesmo quanto à existência e natureza do mundo real, nenhuma pesquisa racional da verdade das coisas parecia possível, pois cada dogma teológico ou teoria científica deveria enfrentar uma bateria de argumentos aparentemente irrefutáveis e a crise pirrônica se impunha ao homem na sua busca de certeza religiosa e científica.

\footnotetext{
183 Popkin, Richard H., op. cit., p. 87.

${ }^{184}$ Idem, p. 93. As semelhaças entre as conclusões fideistas do De libero Arbitrio de Erasmo e a Apologia de Raimond Sebond de Montaigne merecem uma consideração indireta de Popkin: “Contrairement à celui des anti-intellectuels comme Érasme, le doute de Montaigne provenait de la raison. Contrairement à celui de ses prédécesseurs sceptiques qui se contentaient en général de presenter une série de comptes rendus faisant état de la variété des opinions humaines, le pyrrhonisme absolu de Montaigne reposait sur une série de niveaux de doute aboutissant à des difficultés philosophiques cruciales.

${ }^{185}$ Idem, p. 93.
} 
Mas, distante deste quadro teórico já do final do XVI em que esta aguda compreensão sobre a dificuldade teórica em fundamentar a ciência, superando os argumentos céticos, chega a ser o critério para a designação de todo um novo período na história de filosofia chamado de "moderno" - em que pese Pyrrhon d'Elis ter vivido entre 360 e 275 A.C. e que a formulação dos argumentos pirronianos compilados por Sextus Empíricus ter sido feita por volta de 200 A.C. ${ }^{186}$ - ainda no início do XIV e do próprio Renascimento entre os italianos, o contexto e prioridades entre os renascentistas italianos eram outras pois não se discutia a fundamentação do conhecimento, mas antes sua urgente recuperação ou mesmo sua introdução pela primeira vez na Europa ocidental, pois no dizer de Valla nada mais havia sobrado senão barbárie ${ }^{187}$ : depois de mais de mil anos de guerras e dogmatismo religioso - em que o patrimônio retórico grego apropriado e extendido bélica e culturalmente pela civilização romana sobreviveu a esta em ruínas mantidas sob suspeição ou parcialmente por uma Igreja de um Deus único - o movimento intelectual humanista fazia novamente da arte secular da linguagem, a ars loquendi, o fundamento de toda formação cultural individual, obtida e assimilada graças à frequentação, comentário e imitação dos grandes autores da Grécia e Roma antigas e, indo além, propagava a idéia de que a língua e literatura clássicas, modelos de clareza e beleza, deviam ser, efetivamente no mundo prático, a via de acesso a todas as ciências e artes próprias de um homem livre ou a ocupação digna de estima e exigência para qualquer doutrina - ad omnem sapientiam desde que todas estas estavam escritas em latim; que a recuperação e cultivo de ambas restituiria todas as outras disciplinas à antiga perfeição; que ambas seriam requisito imprescindível para qualquer atividade intelectual produtiva futura e dariam à luz um novo período, e então, sobre a palavra antiga, um novo mundo seria construído ${ }^{188}$.

\footnotetext{
${ }^{186}$ Idem, p. 25.

187 D’Ascia, Luca; op. cit., pp. 16 e 17. Este comentador apresenta um trecho pungente do proêmio ao primeiro livro das Elegantiae de Valla que traduzo como segue: “[...] Mas querendo dizer mais, a dor me impede, me faz sofrer e lacrimejar - sed me plura dicere volentem impedit dolor et exulcerat lacrimarique cogit - ao ver em que estado e em que mãos esta [a língua latina] caiu - intuentem quo ex statu et in quem facultas ista [sermonis romani] reciderit - Pois quem, bom amante das letras e dos bens públicos - Nam quis litterarum, quis publici boni amator - controla as lágrimas quando vê em que estado esta se encontra desde que Roma foi capturada pelos Gauleses: - a lacrimis temperet, cum videat hanc in eo statu esse, quo olim Roma capta a Gallis: - tudo revirado, queimado e destruido ao ponto em que mal sobrevive algo da cidadela capitolina? - omnia eversa, incensa, diruta, ut vix capitolina supersit arx ?’

${ }^{188}$ Rico, Francisco, op. cit., pp. 4 a 6 . É preciso matizar para se entender a exata ambição da Renascença e não se supor um anacrônico otimismo científico. Há, sim, um otimismo na restauração das disciplinas. Vide nota 264.
} 
Mas esta imensa tarefa de recuperação do conhecimento perdido, quando alcança o início do XVI, depois de passados já quase dois séculos dos primeiros escritos humanistas - se lembramos que Petrarca nasceu em 1304 - não pode esconder que o ressurgimento da cultura clássica, ao oferecer uma visão tão poderosa das possibilidades humanas de invenção e autonomia, antes de ser conhecido e aceito na Europa setentrional e mesmo plenamente assimilado na Itália, especialmente pelo clero conservador e onipresente no sistema de ensino, necessitava ainda de um esforço extra para conciliá-lo cabalmente à doutrina cristã mediante um competente trabalho teórico-exegético - trabalho apenas começado pelos italianos - além de divulgá-lo convincentemente ao grande público leitor que começava a se formar com a recém-nascida imprensa.

Entre o alvorecer do Trecento e o crepúsculo do Quattrocento os Studia Humanitatis já haviam, pelas próprias mãos de Petrarca, partido de um núcleo de intensos estudos e trabalhos literário-linguístico-históricos para a fase mais madura ligada ao momento italiano, às necessidades de um número maior de leitores, à polêmica com os aristotélicos, à denúncia de falsos diplomas atribuídos a César ou Nero e mesmo à mais modesta realidade cotidiana, demonstrando sua vocação em traduzir-se in actum e dirigir-se ad vitam ${ }^{189}$. O classicismo puro e intransigente da juventude se transformara em um classicismo aplicado que no século seguinte cresceria a ponto de envolver em simbiose, ou ao menos fecundar, outras disciplinas com o seu saber, pois a eloquentia é tão necessária para aqueles que estudam direito civil ou canônico quanto para medicina ou filosofia ou se ocupam de teologia. E pode-se falar de um verdadeiro "imperialismo" da filologia de Valla que assegurava que a restauração da língua de Roma significaria também a restauração de todas as disciplinas e que até a pintura, a escultura e a arquitetura renasceriam com os textos clássicos - cum litteris. Em efeito, as conseqüências da recuperação, e. g., da Geografia de Tolomeu, a Naturalis Historia de Plínio ou o Corollarium de Dioscorideo confirmaram as palavras de Valla quanto às disciplinas e a passagem da língua e literatura

\footnotetext{
${ }^{189}$ Idem, op. cit., p. 44. Este comentador nos traz um trecho do De remediis utriusque fortune de Petrarca que traduzo como segue: "É útil o que nos ensinam as letras - Tunc enim est utilis notitia literarum - enquanto é transformado em ação - dum in actum transit - e a própria realidade o comprova, não as palavras - seque ipsam rebus approbat, non verbis [...] Tudo isto, a não ser que se refira à vida - [...] Haec omnia, nisi ad vitam referantur - o que são a não ser vãos instrumentos e vaidadoso e inútil trabalho e barulho? - quid sunt aliud quam inanis instrumenta iactantie inutilisque labor ac strepitus?
} 
para as artes plásticas já vinha sendo dado por Leon Battista Alberti que influenciava diretamente artistas tais como Mantegna ${ }^{190}$.

Mas ao se colocar em prática o ambicioso projeto de restauração total da Antiguidade, ao se adotar imediatamente os Studia Humanitatis na classe dirigente como elemento próprio do viver aristocrático e ao se fazer destes estudos um programa escolar amplamente aceito da escola municipal à faculdade de artes passando por diversos níveis de ensino privado, era inevitável algum grau de banalização contido inclusive na origem levemente pejorativa da expressão umanista como jargão universitário ${ }^{191}$. Neste quadro, os luminares da universidade marcam distancia dos artigiani dell'umanesimo e preferem, como Ângelo Poliziano, o título de grammaticus, fecham-se na especialização e parecem perder o entusiasmo expansionista. O progressivo domínio da língua e literatura grega ampliou enormemente o campo de pesquisas para a solução de questões de fonte e no esclarecimento das passagens obscuras e da lexicografia alcançando as obras cientificas de, e. g., Aristóteles, Hipócrates, Galeno, Teofrasto ou obras literárias refinadas e plenas de alusões e referências cifradas difíceis de serem comentadas.

A publicação de Miscelanea por Poliziano em 1489 é o ponto alto da filologia e lhe concede o estatuto de disciplina autônoma, mas indicava que a tradição do humanismo italiano se dobrava sobre si mesma em nicho profissional renunciando à sua vocação pública: se em Valla o latim era a única estrada para o conhecimento ad omnem sapientiam propondo conteúdos, paradigmas, estímulo a novos saberes, problemas, métodos e objetivos, já em Poliziano ocorre a inversão e então um conhecimento enciclopédico de todas as artes é imprescindível para explicar os poetas e favorecer a

\footnotetext{
${ }^{190}$ Idem, op. cit., pp. 6, 52, 80 e 42 a 47. Observe-se que o De Pictura de Alberti é de 1435 e as Elegantiae de Valla é de c. 1440.

${ }^{191}$ Kristeller, P. O., op. cit. p. 39. "El latím 'humanista' y sus equivalentes vernáculos en italiano, francés, inglés y otros idiomas fueron términos de aplicación común, durante el siglo XVI, a quienes eran profesores, maestros o estudiantes de humanidades; tal uso siguió vivo y era bien comprendido hasta el siglo XVIII. La palabra, a juzgar por la primera aparición de la que tenemos noticia, parece haber surgido de la jerga estudantil de las universidades italianas, en las cuales el profesor de umanidades terminó por ser llamado umanista por analogía con sus colegas de disciplinas más antiguas, a quienes por siglos se habían aplicado los términos de legista, jurista, canonista y artista.”
} 
latinidade - rem iuvare Latinam ${ }^{192}$. A filologia parecia ter esgotado sua força em influenciar outros saberes ${ }^{193}$.

Se os Studia Humanitatis perdiam na Itália sua força redentora e se contentavam com a erudição da filologia caprichosa e críptica de um Poliziano ou de um Ermolao Barbaro, ao norte dos Alpes estes estudos foram valorizados com maior clareza, talvez por contraste, e por isto estimulavam a busca de objetivos ainda mais amplos, além do importante fato de que as palavras de ordem e as bandeiras heróicas do primeiro humanismo no Trecento chegavam ao mesmo tempo em que as refinadas armas filológicas desenvolvidas e já experimentadas no Quattrocento ${ }^{194}$, ao que devemos ainda juntar uma imprensa já estabelecida ${ }^{195}$. Havia um grande trabalho a ser feito, havia a necessidade de reformas das circunstâncias - rerum ${ }^{196}$ - pois uma multidão de aspectos da existência cotidiana, potencialmente moldáveis ao contato com as letras antigas - portadoras de idéias da filosofia política, moral, literatura e das disciplinas científicas e artísticas - aguardavam sua chegada, o que aconteceria pela primeira vez em muitas regiões da Europa.

Neste quadro, diferentemente da Itália, os Studia Humanitatis não se afastariam jamais do forum, dariam plena vazão às suas características retóricas de origem - segundo o modelo supremo de Cícero - seguiriam sua vocação pública para tratar de questões sociais e políticas urgentes e cumpririam seu destino original de servir ao

${ }^{192}$ Rico, Francisco, op. cit., pp. 57 a 65 e de 69 a 72.

193 Idem, p. 71. É irresistível a sugestão de trazer também deste comentador a lembrança de um trecho da Oratio super Fabio Quintiliano et statii sylvis de Poliziano que ilustra uma faceta erasmiana presente na ambientação dos Antibarbaros, pois seus personagens são emoldurados por uma paisagem de campo nos jardins da 'villa' do cônsul em uma atmosfera semelhante ao que reivindica Poliziano; este trecho traduzo como segue: "Ora, evitemos pois a praça pública, jamais nos dirijamos aos comícios, jamais aos tribunais, jamais aos palanques - Age vero ut nunquam forum, nunquam rostra, nunquam subsellia, nunquam conciones ineamus - O que há de mais prazeiroso que este ócio nesta vida privada? - quid tandem est in hoc ocio atque in hac privata vita iucundius - O que há de mais doce e mais confortável aos seres humanos - quid dulcius, quid humanitati accomodatius - que o uso deste tipo de linguagem que, plena de sábias sentenças, ornada de belas palavras, trabalhada com engenho e urbanidade, nada de rude, nada contenha de impróprio ou grosseiro? - quam eo sermonis genere uti, qui sententiis refertus, verbis ornatus, facetis urbanitateque expolitus, nihil rude, nihil ineptum habeat atque agreste? ”

${ }^{194}$ Idem, pp. 85 e 86.

${ }^{195}$ Quando a Inglaterra ainda não possuía imprensa, Erasmo editou pela casa Aldo Manunccio em Veneza, Froben na Basiléia e em Paris na gráfica da Sorbornne e em Leuven (Louvain) na atual Bélgica.

${ }^{196}$ Em Ciceronianus, Erasmo irá criticar aqueles puristas italianos incapazes de usar uma palavra que não tenha sido empregada antes pelo grande orador impedindo uma linguagem cristã para uso de um cristão e não atendendo ao princípio proposto pelo próprio Cícero de que se deve respeitar as circunstâncias, a finalidade do discurso, o casum . 
indivíduo como sabedoria ad vitam que deve se traduzir in actum como pensava Petrarca. Se é possível discutir sobre a originalidade das idéias propriamente filosóficas de Erasmo $^{197}$, não há dúvida que é a esta vocação e a este destino que o autor atende. Um de seus títulos, o de "Professor da Europa”, deixa claro que seu espírito sempre foi aquele do pedagogo mesmo antes que do erudito, mais preocupado em aprender o que já está pronto para ser ensinado do que descobrir verdades novas de aplicação incerta como testemunha o fato de haver feito, seguindo a escola valliana, todos os manuais e livros de divulgação de cultura que tantos humanistas notórios se abstiveram de escrever, e. g., os manuais de latim $^{198}$. Mas já com a publicação de diálogos didáticos para o aprendizado de latim, começavam a fluír aquelas novas idéias guardadas nas letras antigas e reunindo ainda de maneira melhor o que os italianos haviam separado historicamente: à minúcia do filólogo especialista e pesquisador, Erasmo somava uma particular nonchalance em relação às regras e preceitos gramaticais, recusando o ensino autoritário e atenuando os exercícios

${ }^{197}$ Rico, Francisco, op. cit. O comentador toca neste assunto delicado avançando proposições polêmicas ao tentar julgar a contribuição propriamente filosófica de Erasmo: na p. 92 "D’altra parte, chi analizzi il suo pensiero e le tracce da esso lasciate, poche volte potrà affermare che "l'idea appartiene a Erasmo" senza subito dopo precisare "già Origene (o Girolamo o Tommaso d'Aquino o Lorenzo Valla) aveva scritto alttretanto" (...)”; na p. 118 "Cosí, tra i giorni di Petrarca e l'età di Erasmo, il cogente classicismo formale e tematico che è nei fondamenti dell'umanesimo implicava di necessità un insieme di nozioni dell'uomo, della morale e della religione che il gigante di Rotterdam divulgò con il suo enorme talento e la sua implacabile tenacia, ma la cui paternità non può in alcun modo essergli riconosciuta.", na p. 120 “È d'obbligo sottolineare il vigore drammatico del 'Convivium Religiosum', ma sarebbe falsificare la storia se le argomentazioni appena rievocate venissero presentate, come troppo spesso si è fatto, come specificamente erasmiane, o se per esempio se scrivesse che "tale è la sintesi che Erasmo realizza tra fede e formazione intellettuale, tra la profonda ammirazione per l'antiquità clássica e l'intima adesione a Gesú Cristo”, dando ad intendere che abbiamo a che fare con sviluppi e conclusioni di conio esclusivo dell'olandese. In assoluto: Erasmo non fa che raccogliere ed enfatizzare, conforme ai tempi e alla sua sensibilità, alcuni principi che appartengono al patrinonio costitutivo degli Studia Humanitatis.", na p. 121 "Per ciò stesso è ancora piú suggestivo verificare quanto poco sforzo costi ricostruire con testi petrarcheschi, quasi punto per punto, le pagine piú celebri dell'intero corpus erasmianum" e enfim, na p. 133 conclui afirmando que a obra De remediis de Petrarca teve o mesmo destino da Philosophia Christi de Erasmo “(...) perchè in sostanza Erasmo era tutto dentro Petrarca (...)”. O biógrafo Gautier em op. cit., pp. 23 e 24, também arrisca que “On peut prévoir qu'il n'essaiera pas de pénétrer les secrets des philosophes, qu'il ne pursuivra pas l'oeuvre d'un Marsile Ficin ou d'un Pic de la Mirandole. Il ne possède point l'inquiétude d'esprit nécessaire à des tels travaux.”. Todavia, Lucièn Febvre em op. cit., p. 122, comentando a maneira de Huizinga tratar da originalidade de Erasmo, escreve que: "Tout le livre d'Huizinga est une mise en garde contre une idée, qu'Érasme, finalement, parce qu'il fut un modéré, a moins compté, moins pesé dans l'histoire (de son siècle et des siècles suivants), que les violents. Moins que Luther, si l'on veut, et que Loyola. Eh non! Non et non! Érasme a régné sur la plaine - et la plaine est au moins aussi peuplée que la montagne. Et les gens de la plaine ne l'ont point lâché! Oh! Ils ne se sont pas groupés en bataillons (...) Les gens de la plaine ont une certaine peur naturelle des coups, et de ces grands diables de montagnards aux bras forts et aux humeurs aventureuses; ce qui leur interdit de pareils excès. Simplement, ils ont gardé les leçons d'Érasme dans leur tête. A part eux et pour eux. Ils ont attendu que la tempête s'apaise. Et quand, de nouveau, un pâle soleil s'est remis à luire - ils se sont retrouvés fidèles à Érasme, quant à l'essentiel. Érasme, leur homme.(...)”.

${ }^{198}$ Idem, pp. 92 e 93. 
tratando-os como jogos, pois, fidelíssimo ao essencial dos Studia Humanitatis em sua origem, subordinava o conhecimento técnico da língua ao conteúdo e ao arcabouço de idéias que eram comunicadas. ${ }^{199}$

Partindo do ensino de latim, que continuou a lhe ocupar a atenção como provam as contínuas edições de novos Colloquia, Erasmo adquire conhecimentos da língua grega e passa às traduções de clássicos da Antiguidade e de Pais da Igreja com seus comentários às quais já acrescenta livros de temática independente. A impressionante maquinaria de textos - todos vinculados de alguma maneira à filosofia moral - que cuidadosamente monta, tem nada menos que a esperança de dar uma resposta global aos problemas de sua época renovando profundamente a sociedade pela educação dos indivíduos fundada nos Studia Humanitatis e talvez nenhuma obra exprima melhor a ambição do humanismo que a imensidade deste projeto erasmiano ${ }^{200}$.

Mas se é natural desejarmos discernir sempre com maior acuidade o sentido do calamus ${ }^{201}$ de Erasmo, devemos continuar a arriscar e propor que no seu caso, diferentemente dos italianos, não se trata mais da assimilação da Antiguidade como cristão interessado nas letras ${ }^{202}$, caso de Petrarca, ou do restabelecimento da verdade antiga, das disciplinas e artes como um fim em si ou para servir instrumentalmente ao Homem ou à

\footnotetext{
${ }^{199}$ A título de ilustração, lembro que, o frontispício da edição de 1522 da coleção de Diálogos - Colloquia pela casa editora Froben na Basiléia, traz o seguinte título "Familiarivm Colloquiorvm Formulae per D. Erasmum Roterod. Non tantum ad linguam puerilem expoliendam utiles, verum etiam ad vitam instituendam." que pode ser traduzido por "Fórmulas para a conversação quotidiana de D. Erasmus Roterodamus. Úteis não apenas para a ensino da língua às crianças mas também para a sua formação pessoal”.

${ }^{200}$ Rico, Francisco, op. cit. p. 134.

${ }^{201}$ Desiderii Erasmi, LB, X,1691 E. Na carta a Joanni Sapido - nome latinizado de Johannes Witz, nascido c.1490, humanista alsaciano e reformador prático do ensino público da cidade de Sélestat - que prefacia os Antibarbaros, Erasmo reclama daqueles que o desestimularam ao estudo das Musas e afirma que nomeará seu calamus (apetrecho com que escreve) como seu vingador - (...) institueram ulcisci me calamo (...) - mas com moderação e sem citar nomes, acrescenta.

${ }^{202}$ Érasme de Rotterdam, La Langue, op. cit., p. 61 . O tradutor comenta no final de sua introdução “(..) il est tout d'abord décisif de noter que, pour s'opposer au bavardage, Érasme propose un retrait du langage dans la langue divine. Nous entendons par retrait le fait de se réclamer d'une langue qui resterait à l'abri de ce que toutes sortes de forces centrifugues lui infligeraient, si elle sy livrait: perte du secret, perte de l'interiorité, mais surtout perte du sens. Cette langue divine, accessible aux hommes par les Textes sacrés et par l'imitation du Christ (...)".
} 
religião como em Valla e outros eruditos ${ }^{203}$, ou muito menos da pura recuperação da latinidade como finalidade justificável por si mesma como em Poliziano ou do trabalho teórico-enciclopédico feito em um gabinete pela unidade da verdade entre cristianismo e a Antiguidade como em Ficino e mais ambiciosamente em Pico, mas antes da retomada em ação - in actum - da tradição filosófico-retórica contida nos studia Humanitatis exatamente como defendido por Cícero - dando continuidade ao pensamento original de Sócrates e da retórica de Isócrates ${ }^{204}$ na igual maneira como estes concederam prioridade à filosofia moral e política, subordinando um tratamento eclético das diferentes filosofias à exclusiva reflexão sobre os problemas do Homem e à definição de seu Sumum Bonum - respondendo à premente necessidade de conciliação e diálogo entre a literatura pagã e o cristianismo ${ }^{205}$ e, o que é sutilmente diverso do cristianismo e mais difícil, entre esta literatura e a teologia e a doutrina da Igreja, para a demonstração de sua afinidade. Longe de ter buscado o

\footnotetext{
${ }^{203}$ Gautier, Vignal L., op. cit., pp. 20 e 21. Erasmo estudou na escola de Deventer entre 1475 e 84 que foi dirigida a partir de 1483 pelo humanista Alexander Hegius (Alexandre de Heck) que por sua vez havia sido aluno de Rodolfo Agricola (Rodolphe Husmann), o primeiro a trazer da Itália para o Norte da Europa o gosto pelas letras clássicas. Este chegou mesmo a visitar, pouco antes de morrer, a escola de seu antigo aluno Hegius causando forte impressão no jovem Erasmo. Luca D’Ascia acrescenta que Agricola conhecera em Ferrara o famoso pedagogo Guarino Veronese e celebrara com seu Vida de Petrarca o autêntico iniciador do movimento humanista, mas pondera que Erasmo não o conheceu pessoalmente (op. cit., p. 13).

${ }^{204}$ Érasme de Rotterdam, Éloge de la Folie, op. cit. O autor conhecia Isócrates pois, além de ser seu tradutor, o cita na carta dedicatória que prefacia o seu Encomium Moriae quando argumenta que mesmo os grandes escritores se ocuparam de temas ligeiros e divertidos: "De grands auteurs en ont fait autant. Il y a des siècles qu'Homère s'est amusé au combat des rats et des grenouilles; Virgile au Culex et au Moretum; Ovide à la Nux; Polycrate a louangé Busiris qu'Isocrate flagella (...)” (p. 5). Também no corpo do texto a 'Loucura', ao citar exemplos de sábios que preferiram se calar, lembra que "Isocrate fut si timide qu'il n'osa même jamais ouvrir la bouche. (...)” (p.45).

${ }^{205}$ D’Ascia, Luca; op. cit., p. 56. É difícil responder a uma questão tão ampla como aquela que pergunta se Erasmo foi, enfim, um humanista que cuidou de assuntos teológicos ou foi um clérigo tocado pela necessidade, conveniência ou superioridade, em algum sentido, dos Studia Humanitatis. O comentador arrisca-se e propõe: “Erasmo, come Batt, rimane 'e poeta teologus': non muove dalla tradizione ecclesiastica per assimilare saperi umanistici, ma, al contrario, mette a frutto una generale e mai rinnegata disposizione umanistica nel campo specifico degli studi biblici." No entanto, prefiro a liberdade de a cada passo ressaltar uma nuance ou outra, seguindo os ensinamento do próprio autor, célebre por sempre propor distinções interpretativas - distinguere semper - fugindo das classificações peremptórias, tão rápidas quanto provisórias.
} 
resgate de um tipo humano fixado em uma língua ${ }^{206}$ e criado olimpicamente mais uma obra para a confluência teórica de dois mundos com religiões diferentes, Erasmo talvez se diferencie ao conciliar e sustentar durante toda a sua vida as posições cristãs e pagãs descendo aos pormenores práticos do cotidiano e às minúcias exegéticas bíblicas, através de seus numerosos livros e cartas e, sobretudo, por efetivamente estimular e sustentar

${ }^{206}$ Quanto ao significado da linguagem para Erasmo, nos distanciamos também da abordagem de Paul Jacopin e Jacqueline Lagrée que, vinculando sobremaneira o autor ao primeiro humanismo de Petrarca, Valla e Poliziano, perdem de vista o humanismo em seus últimos estágios, já emancipado das fronteiras italianas, e parecem ainda atribuir a ele uma anacrônica e verdadeira hipóstase da linguagem como deixam transparecer em vária passagens: “Mais le langage n'est pas seulement le milieu de l'institution de l'humanité (...)” ( op. cit, p. 5) ; "[Para Erasmo, o humanismo] renvoie au primat des langues anciennes et de la culture grécolatine comme moyen d'accès aux connaissances qui importent à la formation d'un homme, (...)” (idem, p. 14), “ [Na Renascença] on doit étudier une langue pour la parler, pour s'emprégner de son milieu intellectuel et culturel, pour penser, vivre et s'exprimer dans cet élément (...) Il fault donc connaître parfaitement les langues anciennes (...) et perpetuer leur vie” (idem, p. 18), “(...) les vrais amis (de Erasmo) ce sont les livres” (p. 22), “On pourrait dire qu'il y a chez Érasme un primat herméneutique de l'écriture (...) c'est le livre qui donne sens à la vie en l'épurant de ses détails insignifiants (...) “ (p. 22), “La philologie est une école de veracité (...)”, (р. 23), “(...) les sages qui connaisent le sens et la portée des mots et les méchants et les sots qui font plus de cas du mot que de la chose." (p. 23), "On est homme non par la naissance mais par l'éducation (...)” (p. 24), "Érasme affirme retrouver le vrai sens d'une tradition (...) qui definit l'homme comme l'animal doté de logos, en même temps qu'il privilégie, face à une qualité abstraite, la raison, une réalité observable, l'aptitude au langage (...)" (p. 25), "Le projet éducatif se développe donc comme un affinement progressif de cet aprentissage de la langue." (p. 27), "D’une bonne éducation de la langue dépendent la dignité et felicité de l'être humain.", “L'apprentissage de la langue n'est pas seulement une transmission de connaissances, c'est aussi le chemin pour accéder à la vertu et à une foi éclairée” (p. 28), "La maîtrise de la langue est un instrument de l'exercise par l'homme de sa liberté" (p. 30), "Le but final de cet apprentissage est la maîtrise parfaite de la langue pour pouvoir s'exprimer avec aisance et élegance: lire les textes, écrire pour pouvoir parler.” (p. 36), “Toute l'oeuvre d'Ërasme (...) se propose de fournir matière à l'enrichissement d'un discurs." (p. 39), "L'opposition entre le vulgus, le vulgaire, la foule, et les hommes vraiment pieux semble transposer dans l'ordre religieux la hiérarchie des rhéteurs entre l'homme éloquent et la masse illettrée.” (p. 76). Esta série de extratos parecem indicar que Erasmo hipostasia uma linguagem humana entre outras; toma uma criação humana - as línguas clássicas e sua literatura - como proposição e possibilidade de um tipo humano ideal e perene; assume uma determinada tradição literária como realização definitiva e insuperável, uma criação acabada que se eleva sobre seu criador e então, a todos os homens que pensam, tocasse o destino individual de Pigmaleão, apaixonado por sua própria obra. Penso que já na socrática e permanente pergunta sobre o Bem, que encontramos na liberdade da exegese erasmiana e no debate ético constantemente proposto pelo autor, especialmente em seus colloquia, se estabelece a impossibilidade das humaniores litterae constituirem uma dogmática e mesmo se apresentar como um valor em si, finalidade de sua própria atividade como um sistema auto-referencial, produzindo critérios de julgamento aplicados a si mesma e a outras tradições literárias apenas no próprio interesse. Em várias ocasiões o autor mostrou-se independente: escreveu mesmo um vituperatio rhetoricae que inicialmente integrava o próprio Antibarbarorum Liber e foi lido por John Colet, também escreveu o audacioso Ciceronianus contra os servis imitadores de Cícero, sempre condenou toda forma de paganismo disfarçado pelo amor à forma e, enfim, frequentemente se referia aos Studia Humanitatis como decoração e ornamento do "templo do Senhor". 
um denso e público debate ético - como nos seus Colloquia ${ }^{207}$ e Adagiarum Collectanea ${ }^{208}$ - no amplo sentido socrático, oferecendo aos seus leitores e interlocutores o patrimônio das conquistas realizadas pela filosofia moral antiga ${ }^{209}$ na permanente busca da paz e da concórdia ${ }^{210}$.

A busca pela assimilação teórica da Antiguidade ao cristianismo, a rigor, como já vimos, não era uma preocupação nova na época de Erasmo pois no século XV Pico de la Mirandola havia feito uma tentativa de demonstração da convergência não só entre a doutrina cristã e o classicismo greco-romano, mas também entre estes e as religiões

${ }^{207}$ Carena, Carlo, prefácio a Erasmo da Rotterdam - Il lamento della Pace, op. cit., p. 16. “(...) os Colloquia, este outro fruto cintilante do espírito de Erasmo, a ponto de colocar de lado o Elogio da Loucura; pequenos quadros de gênero, conversações serradas, vivos como atos de uma enorme comédia bufa e satírica nas suas cenas eclesiásticas ou laicas, idealizadas para reformar a humanidade e trazê-la de volta ao juízo, à tolerancia, à educação, à honestidade e à pureza e sinceridade, desde sempre e para sempre, ideais erasmianos.”

${ }^{208}$ De Bujanda, J. M, op. cit., p. 13. "Esta obra [o Adagiarum Collectanea] constantemente atualizada por seu autor, conhecerá mais de sessenta edições durante a vida deste e será o breviário dos humanistas do século XVI. Com esta obra, o cidadão de Roterdam (sic) oferecerá ao mundo de sua época um epítome da Antiguidade clássica. É principalmente por causa deste livro que mereceu o título de "Principe dos Humanistas”. Através dele Erasmo encarna o ideal do humanismo (...) a descoberta dos clássicos grecolatinos para deles extrair a pureza de seu estilo e sua filosofia de vida” (grifo meu). Na p. 14 este comentador é mais enfático: "Ele [Erasmo] tem um programa de liberação, de reforma, que se exprime por uma crítica mordaz de tudo o que mantém o homem na sua condição de dependência e de inferioridade. Ele crê possuir uma vocação para colocar à nu as chagas da sociedade e da Renascença. É por meio da imprensa que ele se propõe trazer a consciência coletiva a uma nova mentalidade, de educar as pessoas para uma nova atitude diante da vida.” Também Carlo Carena em seu belo prefácio a Erasmo da Rotterdam - Il lamento della Pace afirma: "Cominciava così la raccolta di proverbi classici degli Adagia, usciti in prima edizione a Parigi nel 1500 e in séguito continuamente arrichiata fino a raggiungere proporzioni monumentali: immensa miniera di erudizione e tesoro di una mente vigile, brillante, caustica e poetica insieme, una delle opere in cui meglio si è depositato lo spirito europeo, sapienza socratica e dottrina umanistica, sovrabbondanza di sapere e domínio delle cose, precisa cognizione della vita.” (op. cit., p. V).

${ }^{209}$ Margolin, Jean-Claude; prefácio a Érasme - Les Silènes d'Alcibiade; Col. Le Corps Eloquent, Paris, Les Belles Lettres, 1998, p. XVI. Ao prefaciar o comentário erasmiano ao adágio Os silenos de Alcibíades, o professor Margolin explica como o autor trata os adágios que colhe da Antiguidade: “(...) Mais a grande arte, que lhe fará talvez mais inimigos que admiradores, consistirá em um imenso desvio [do tema inicial] ele se distancia mais e mais do centro e do nó da questão, como em uma vasta aspiral onde a associação de imagens e de idéias será rainha, onde as digressões, as rupturas de tom, as referências muito precisas (ou mal encobertas) ao mundo contemporâneo no qual ele escreve e age nos fazem perder de vista os silenos, Alcibíades e Sócrates. Ele então faz do seu jeito (e como!) exprimindo suas idéias e, sobretudo, suas criticas sobre a política que se pratica a sua volta, sobre o funcionamento da Igreja ou o comportamento de muitos prelados, conclamando, com todas as suas forças e toda a energia de sua pena cortante, por uma reforma tanto dos costumes eclesiásticos quanto dos leigos (...)”. O prefaciador antecipa um revelador trecho da obra: [escreve Erasmo] “ No entanto, eu não lamentarei tanto esta digressão [ter fugido do assunto] se o que não permite uma clara elucidação do adágio, permite a melhoria da vida e se o que não acrescenta nada à ciência contribui em promover a piedade e, afinal, se o que parece fora de propósito e extemporâneo com relação ao plano colocado em execução neste trabalho, pôde se adaptar a um programa de vida”.

${ }^{210}$ Margolin, Jean-Claude, op. cit., p. IX. O professor Margolin no seu prefácio Érasme notre Contemporain nos lembra a famosa carta ao Arcebispo de Palermo, Jean Carandolet, em que Erasmo explicita: "Le fondement de notre religion c'est la paix et concorde". 
orientais através de suas famosas 900 teses; e Marsilio Ficino no próprio nome de sua obra principal, Theologia Platonica, já havia revelado seu desejo de síntese. Mas é preciso acrescentar que o próprio Petrarca, a quem melhor cabe o título de pai do Humanismo ${ }^{211}$, já no século XIV, ao estudar Platão e Agostinho e tratar do Sumum Bonum nas suas Familares havia proposto que a felicidade está no fruir e amar a Deus de modo que o autêntico filósofo não é outro que um bom cristão, idéia fortalecida pela convicção de que a filosofia não se funda apenas sobre a palavra, quanto menos em silogismos, mas sobre fatos, pois ela não é arte das palavras e sim de vida ${ }^{212}$; Petrarca ainda ao responder às reticências quanto a sua frequentação de poetas e filósofos pagãos havia declarado que nenhum guia é digno de desprezo se mostra o caminho da salvação - Nemo dux spernendus est qui viam salutis ostendit - e, ao reclamar que os doutores da teologia especulativa eram gélidos pois não sabiam lhe entusiasmar com o fogo capaz de torná-lo melhor como faziam os escritores pagãos, havia imputado a culpa ao próprio sumo pontífice da escolástica, Aristóteles, com cujas obras morais tornara-se talvez sempre mais douto mas não, como seria desejável, melhor - “(...) doctior his forsitam nonnunquam, sed non - qua decunt - melior factus ad me redii, 213 .

E ambos estes posicionamentos petrarquistas são de fato assumidos posteriormente por Erasmo em um mesmo trecho de seu diálogo Convivium Religiosum onde este escreve "Não se deve definir como profano algo que contenha doutrina de piedade e seja favorável aos bons costumes. (...). Ao contrário, quando leio os autores recentes escreverem sobre política, economia e ética, deuses imortais, quanto se tornam frios em comparação com os antigos: vê-se que não sentem aquilo que escrevem. Assim suportaria de maneira pior a falta de um só livro de Cícero ou de Plutarco que de tudo

\footnotetext{
${ }^{211}$ Cassirer, Kristeller e Randall Jr., op. cit., p. 3. "Petrarca, who was not so much its initiator as its first major representative, may still be called the 'father of Humanism.' since his autority and influence gave the whole movement a strong impulse".

${ }^{212}$ Rico, Francisco, op. cit., p. 117. O comentador cita de Petrarca as suas Familiares, XVII, I, 7-16: a filosofia não se funda em palavras, e muito menos em silogismos, mas em fatos, não é "verborum [...] ars, sed vitae" e trecho análogo no Institutio princepis christiani, Opera Omnia, ASD, IV, p. 145, de Erasmo que pode ser traduzido como segue: "Portanto, é filósofo não aquele que caleja as mãos na Dialética ou na Física, mas aquele que despreza as falsas imagens das coisas e com coragem vê e segue a verdade. As palavras são diferentes, mas é a mesma coisa ser filósofo e ser cristão. - Porro Philosophus is est, non qui dialecticen aut physicien calleat, sed qui contemptis falsis rerum simulachris infracto pectore vera bona et perspicit et sequitur. Vocabullis diversum est, caeterum re idem esse philosophum et esse Christianum."

${ }^{213}$ Idem, p. 122.
} 
quanto tenha escrito Scotus e seus colegas, não que os condene sem remissão, mas porque sinto que a leitura dos primeiros me edificam enquanto a leitura dos outros me deixam frio face à autêntica virtude e mais inclinado à disputa"214. Mesmo o mais celebre fragmento de Erasmo, que é emblema da síntese entre a doutrina cristã e a profana Antiguidade clássica, que é a invocação “Sancte Socrates, ora pro nobis! ” presente no mesmo diálogo, já é antecipada em certa medida também por Petrarca quando, no seu De vera religione, o capítulo em que expõe a exortação de Sócrates para que seus concidadãos procurassem um só Deus é concluído entusiasticamente com a sentença: “Vere et sancte et pie”215.

Portanto, este esforço teórico em tornar congruentes o cristianismo com seus mais de mil anos de desdobramentos em forma de valores estabelecidos, sacramentos, dogmas, liturgias, preceitos eclesiásticos e práticas devocionais e o patrimônio de invenções e descobertas literárias, científicas e filosóficas do classicismo greco-romano, recente e progressivamente recuperado - esforço fixado pela imagem da canonização leiga de Sócrates - é exercitado já pelo primeiro humanista, pois era uma questão incontornável para quem se entregasse à exploração da Antiguidade meditando algum projeto de restauração, desde que o trato do mundo pagão à época não podia se dar sem uma sincera justificação intima e pública do ponto de vista religioso ${ }^{216}$.

\footnotetext{
${ }^{214}$ Idem, pp. 118 a 120” - “Imo prophanum dici non debet quicquid pium est et ad bonos mores conducens. (...). Contra quum hos quosdam recentiores lego de republica, oeconomica aut ethica praecipientes, deum immortalem, quam friguent prae illis, imo quam non videntur sentire quod scribunt, ut ego citius patiar perire totum Scotum cum aliquot sui similibus, quam libros unius Ciceronis aut Plutarchi, non quod illos in totum damnem, sed quod ex his sentiam me reddi meliorem, quum ex illorum lectione surgam nescio quomodo frigidius affectus erga veram virtutem, sed irritatior ad contentionem.”

${ }^{215}$ Idem, p. 123.

${ }^{216}$ Gilson, Étienne, op. cit., p. 124. É necessário um verdadeiro esforço de imaginação aplicada à história para se recuperar sem anacronismos a real dificuldade que um filósofo da Renascença teve que enfrentar; neste sentido são insubstituíveis as seguintes linhas de Gilson em op. cit., pp. 757 e 758 : "Da mesma maneira que em nossos dias a reflexão do filósofo não pode não se exercer sobre os resultados mais gerais das ciências históricas e sociais, ela quase não pode se exercer na Idade Média sobre outra coisa a não ser a Revelação do qual o dogma é a expressão. O mundo imediatamente dado, como hoje nos é dado este da ciência, era então aquele da fé. O universo aparecia como a criação de um só Deus em três pessoas. Jesus Cristo, o filho de Deus, engendrado e não criado, consubstancial ao Pai, que se encarnou e se fez homem para nos salvar do pecado de Adão. De seu lado, o homem decaído deve colaborar com esta obra de salvação, se submeter aos mandamentos de Deus e da Igreja de Deus a fim de evitar a perdição eterna e de gozar eternamente a felicidade celeste reservada aos eleitos. Esta vasta perspectiva, enriquecida e detalhada pelo paciente trabalho dos Padres é aquela que a Idade Média impôs a todos os espíritos. A realidade era então, nesta época, diretamente sentida e pensada como religiosa. O que é preciso compreender e explicar é, tanto quanto ou mais que aquilo que os olhos vêem, aquilo que os Concílios definiram a respeito da origem do mundo e do homem assim como do destino de ambos (...).”
} 
E no momento mesmo desta consideração sobre o sentimento religioso expresso por Petrarca, devemos exercitar uma arte desenvolvida pelos próprios humanistas, pois a sua filologia exigia pioneiramente a inserção de toda imagem literária, texto, frase ou palavra antiga no seu quadro histórico de origem, o chamado método crítico, para a compreensão de seu real sentido, o que nos obriga a reconstituir um traço da Renascença muito desfavorecido por preconceitos: não há uma irreligiosidade renascentista que a Reforma tenha derrotado ${ }^{217}$, um paganismo renascentista programático atrás das alegorias literárias; não é correto que toda separação aristotélica entre razão e fé tenha sido hipócrita e encoberto um ateísmo secreto pois no período foram poucos os ateus verdadeiros e houve apenas alguns panteístas; há sim o crescimento constante e irreversível de interesses intelectuais não religiosos, não tanto opostos no seu conteúdo à doutrina religiosa quanto competidores na obtenção da atenção individual e pública ${ }^{218}$.

Também, segundo o mesmo método crítico, não se deve identificar este esforço humanista na assimilação do legado clássico pelo cristianismo à criação intelectual dos Padres da Igreja a ponto de ver nestes humanistas 'avant la lettre' sob o risco de se perder a noção de diferença ao se esquecer que os primeiros autores cristãos, falantes originais da língua aramaica, ao se proporem difundir a nova religião a partir da Palestina judia para toda a área mediterrânea, se viram condicionados a escrever em uma região que pertencia politicamente ao Império Romano, mas integrava culturalmente o mundo helênico, e por isto formaram o corpus do Novo Testamento escrito em grego, língua que no entanto já possuía marcas profundas de uma ampla tradição literária e filosófica e exigia um esforço teórico de incorporação, não só de palavras, mas de conceitos inusitados para a

\footnotetext{
${ }^{217}$ Burckhardt, Jacob, La Civilisation de la Renaissance en Italie - Essai Tradução de H. Schmitt, revista e corrigida por Robert Klein, Paris, Librairie Plon e Club du meilleur livre, Tomo I, 1958, p. XXXIII. Robert Klein, também assina o prefácio onde elogia Burckhardt especialmente pela maneira como tratou a questão da religião na Renascença: "Les pages sur la religion sont parmi les plus justes et les plus vivantes de son livre. Elles réagissaient contre la tradition séculaire qui avait presenté la Renaissance comme une période d'incredulité, un peu à la manière du siècle des lumières"

${ }^{218}$ Kristeller, P. O, op. cit., pp. 93 a 95. O autor é incisivo: "Esta imagen de un supuesto paganismo renascentista, que los historiadores trazaron con gran horror o con gran entusiasmo, dependiendo esto del vigor de sus convicciones religiosas o irreligiosas, em parte se puede ser eliminada si la tomamos como resultado de leyendas y prejuicios posteriores. En cierta medida, tiene su origen en los cargos que contra los humanistas y filósofos lanzaron gente de su época, hostil y estrecha de miras, cargos que no pueden ser aceptados al pie de la letra.". E ainda claro ao dizer: "Sin embargo, dado que se conservaron o transformaron las convicciones religiosas del cristianismo sin que nunca se llegara a atacarlas verdaderamente, parece conveniente llamar al Renacimiento una época fundamentalmente cristiana."
} 
cultura hebraica em um processo mais próximo à integração que à simples tradução; outrossim, nos séculos seguintes, os primeiros apologistas, os Padres gregos e os grandes concílios também tiveram como tarefa definir e desenvolver a doutrina cristã continuando este esforço intelectual para torná-la aceitável e compreensível em todo o mundo de fala grega, i. e., no seu mundo helênico contemporâneo ${ }^{219}$.

Já os humanistas, longe de uma pura necessidade apostólica e evangelista dos primeiros cristãos - vide o exemplo da catequização da América, também ela diferente do apostolado dos primeiros cristãos, pois as diferentes línguas indígenas e suas idéias peculiares são apenas imagens moldáveis e descartáveis, senão obstáculos, em um simples processo imperativo de substituição de uma doutrina religiosa por outra, com heróicas exceções - parecem em geral cristãos de nascimento que, movidos pelo desejo de conhecer todo um acervo de invenções literárias inusitadas na Europa e que aos seus olhos revelavam um valor em si enquanto artifício humano merecedor de admiração - mirabilis - se deixavam arrastar pelo irresistível fascínio de uma nova visão do Homem, portador à época, de uma surpreendente e desejável dignidade e ansiavam sincera e urgentemente acomodá-la ao seu ideário religioso e aos de seus contemporâneos como bonae litterae ${ }^{220}$.

Para esta original acomodação feita pelos humanistas, no entanto, era necessário um esforço pontual, como uma delicada costura fio a fio, pois naquela literatura clássica a cada frase ou palavra podia se encontrar asserções inaceitáveis para um cristão, sentenças desonestas, supersticiosas, sacrílegas, imorais, blasfemas de modo que se impunha para seu estudo e leitura a neutralização destas evidências. Uma das soluções mais utilizadas foi o recurso à interpretação alegórica, verdadeiro trabalho de exegese, atribuindo às passagens mais anticristãs um significado congruente com a doutrina da Igreja, à moral e aos costumes; mas o expediente mais eficaz foi o de evitar calculadamente os lugares mais arriscados e enfatizar o conteúdo per se aceitável, afinal todas as escolas de filosofia antiga concordam em associar, mesmo que com diferentes nuances, felicidade e virtude, a maior

\footnotetext{
${ }^{219}$ Idem, pp. 97 e 98.

${ }^{220}$ No mercado editorial, o conceito Belle Lettres é ocasionalmente utilizado anacronicamente - contra a ratio temporum - para o período renascentista, pois pertence ao registro estetizante característico do século XIX apenas, diferentemente da autêntica expressão Bonae Litterae em que é claro o acento no registro ético.
} 
parte dos sábios do paganismo pensaram a alma imortal, recusaram responder à injustiça com a injustiça e preferiram a busca da verdade à satisfação das paixões, ensinaram que tudo é comum entre amigos ${ }^{221}$ : todos preceitos que sob roupagens e modos antigos e até estranhos à religião eram eticamente válidos para o cristianismo. Sutil diferença que será sempre insinuada por todos os humanistas como na fórmula utilizada por Erasmo no seu Paraclesis em que sugere que se pode encontrar nos livros dos gentios muitas concordâncias com a doutrina de Cristo - permulta reperire licet in Ethinicorum libris quaecum (Christi) doctrina consentiant. Nesse sentido, para se apropriarem da literatura clássica e fazê-la sua harmonizando-a à religião por eles professada, os humanistas, além de exercitarem a tolerância às idéias e comportamentos que teoricamente não lhes seriam aceitáveis - e menos ainda aos seus contemporâneos - se entregaram à busca apaixonada por constantes éticas que em última instância unissem os homens, cristãos ou gentios, acima das diferenças de tempo e fronteira ${ }^{222}$.

Este caminho em busca de valores éticos denominadores mínimos entre o cristianismo e o classicismo conduz ao gradual e discreto obscurecimento de todo um campo da realidade cristã, onde se acumularam aspectos não essenciais, superficialmente religiosos, valores secundários, sacramentos, ritos, cerimônias, liturgias, preceitos detalhistas, costumes, todos radicados na longa tradição, porquanto que a assimilação assimilatio - dos clássicos ao cristianismo, pelo que possuem de central, implicava compreensivelmente a atenuação, relativização, condenação silenciosa ou mesmo desprezo e crítica das diferenças periféricas, como é o caso em Modus orandi Deum onde Erasmo critica a maneira como é feita a milenar condenação pela Igreja dos ritos profanos como costumes supersticiosos e maléficos ao mesmo tempo em que se aceita silenciosamente a continuidade destes quando travestidos de cristãos, pois se na Igreja primitiva a transição dos ritos pagãos para os ritos cristãos foram inicialmente estimulados pelos Padres com

\footnotetext{
${ }^{221}$ Amicorum communia omnia, primeiro adágio de Erasmo que abre o seu primeiro milhar de adágios adagiorum chiliades - É um procedimento sempre utilizado pelo autor, o partir de uma sabedoria arcaica comum, guardada por provérbios, ilustrá-la pelo comentário de algum filósofo e elevá-la ao ensinamento no plano moral, em seguida ao plano espiritual e até aquele teológico.

${ }^{222}$ Rico, Francisco, op. cit., pp. 124 a 126.
} 
uma finalidade pedagógica, passados estes tempos, era necessário abandonar estas práticas persistentes ${ }^{223}$.

Nesta busca de denominadores comuns e de depuração do que é excessivo, chega-se imperceptivelmente à redescoberta do "homem interior" para a religião; consciência religiosa recalcitrante em relação às instituições e suas normatizações, sóbria nas suas manifestações confessionais e muitíssimo atenta, ao contrário, à sua existência ética ${ }^{224}$, e ressalte-se, tão distante da religiosidade supersticiosa de quem se pretende ex opere operato ao invés de ex opere operantis ${ }^{225}$ - marcada pela exterioridade dos ritos - quanto da profunda interioridade mística da comunhão com Deus dos exemplii de São Bento e especialmente de São Francisco de Assis e de seus primeiros seguidores ou ainda do movimento espiritualístico norte-europeu da Devotio Moderna marcado pela leitura da Imitatio Christi. À diferença destas iniciativas espiritualísticas de retorno à religião primitiva que também criticam a simplista ritualização da fé - mas que pela própria dinâmica de sua absorção pela sociedade acabam também por se cristalizarem em instituições, irmandades e ordens zelosas de seus preceitos e distinções - os humanistas conduzem sua religiosidade para uma interioridade que, permanecendo em um plano intelectual orientado para a vida prática, e reservadamente aquém da radicalização da introspecção agostiniana e a conseqüente imersão ou diluição do indivíduo na divindade, se aproxima da autonomia moral clássica do homem capaz de resolver sozinho complexas questões éticas apenas com o auxílio da sabedoria obtida pelo exercício da sua razão natural. Portanto, o caminho da conciliação dos cristãos com os autores clássicos conduz à

\footnotetext{
${ }^{223}$ Jacopin, Paul, Lagrée, Jacqueline; op. cit., pp. 61 e 62. “Comme les païens avaient coutume de purifier les champs par des rites stupides ou de se concilier Cérès par des cantiques que chantaient jeunes gens et jeunes filles, (les Pères voulurent) que les chrétiens portent autour des terres l'étendard de la croix avec des hymnes en l'honneur de Dieu et des saints; que le soldat partant en guerre se recommande non plus à Jupiter mais à saint Georges ou à sainte Barbe; que les cités adoptent en guise de dieux tutélaires Bavon, Marc ou n'importe quel autre disciple du Christ; comme ils avaient coutume d'eloigner la foudre par des claquements de langue ou d'autres remèdes profanes et superstitieux, qu'on fasse sonner les cloches consacrées ou brûler des rameaux bénis pour obtenir le même effet."

${ }^{224}$ Rico, Franacisco, op. cit., pp. 126 e 124.

${ }^{225}$ Jacopin, Paul, Lagrée, Jacqueline; op. cit., p. 61. Alguém que através de objetos, procedimentos físicos ou recepção de gestos, i. e., do que é externo, pretende mudar sua própria essência e não, ao contrário, manifestar uma essência através destes. Vide o alerta trazido pelo autor no seguinte trecho do seu Enchiridion Militis Christiani em que o batismo é comparado às antiga cerimônias de purificação: “Dieu hait ta religion épaisse et grossière. Tu es baptisé. Ne va pas te figurer aussitôt que tu es chrétien. Ton âme entière ne respire encore que le monde. A l'extérieur tu es chrétien; au-dedans, plus païen que un païen."
} 
focalização de suas semelhanças no núcleo das questões éticas, o que implica a pressuposição de uma sabedoria natural comum aos homens - communis hominum sapientiam.

O interesse nesta conciliação leva em geral todos os humanistas, como diríamos hoje, à solução lógica reducionista; solução que hoje parece ter sido inescapável para a época, solução que define e marca sua religiosidade e que, por um caminho inusitado, acaba enfim por encontrar na própria tradição do cristianismo o "culto no espírito”, um modelo de devoção com que se identifica plenamente, pois este é coerente com a assunção dos Studia Humanitatis no âmbito da fé cristã expressa como própria e irrenunciável. Foi esta a religiosidade que tocou a todos os humanistas, se encontra em Erasmo e já é manifesta em Petrarca como mostra o episódio em que este era acusado, em um fragmento de sua obra Africa, de atribuir uma locução demasiado cristã ao personagem Magone, irmão de Aníbal que, ferido fatalmente em batalha contra os romanos, ainda tentava navegar de volta para Cartago: “Ah, como é miserável o fim de um destino tão alto! Como as riquezas cegam a mente! Loucos são os poderosos que felizes vivem à beira do precipício”. ${ }^{226}$ A réplica, através de suas Seniles, é um manifesto exemplar do credo que será de todos os humanistas:

"O que, por Cristo, pergunto, o que há de cristão lá (na frase de Magone), que não seja antes humano e comum a todos os povos? O que há lá a não ser dor, choro e arrependimento à beira da morte? E não há lá expresso o nome de Cristo, santo e aterrador, nos céus e no inferno, pois não se encontra entre aquelas letras por razão temporal; não há nenhum artigo de fé, nenhum sacramento da Igreja e nada do evangelho, nada absolutamente que não passe pela cabeça de um homem que se apresse ao fim de sua experiência (terrena) e que não possa alcançar segundo seu engenho natural e razão inata: como se, por um e outra, não fossemos sempre vencidos! Pode reconhecer seu erro e por isto envergonhar-se e lamentar o homem não cristão; se o resultado é desigual, o arrependimento é igual. Se bem que ninguém a não ser o cristão saiba a quem e de que

\footnotetext{
${ }^{226}$ Rico, Francisco, op. cit., p. 128. “ Heu, qualis fortune terminus alte est! Quam letis mens ceca bonis! Furor ecce potentum precipiti gaudere loco (...) “.
} 
maneira confessar, no entanto, o conhecimento do erro, remorso da consciência, arrependimento e confissão são comuns a todos os capazes de razão.” 227

Pois bem, esta resposta confirma o caráter reducionista da religiosidade humanista e nos lança diretamente para um traço, senão original, distintivo da obra de Erasmo, afinal quem - a partir dos próprios quadros da Igreja e da intimidade com seus dirigentes, evitando todas as armadilhas teológicas e buscando a conciliação do cristianismo com a Antiguidade - poderia esclarecer sua época sobre a peculiaridade do cristão, o povo eleito, sua vantagem sobre os gentios, e tratar da delicada pergunta que ficara insinuada, explicando convincentemente por que "ninguém a não ser o cristão sabe a quem e de que maneira confessar" - cui et qualiter confitendum sit nemo nisi cristianus noverit, como apenas indicado acima por Petrarca? A defesa da unidade da verdade entre o cristianismo e o paganismo deveria valorizar o emprego da razão natural pelos pagãos e simultaneamente fundamentar a precedência da doutrina cristã; isto exigia a cuidadosa articulação entre teologia, história e filosofia, mas no difícil período inaugural do humanismo, o grande poeta havia preferido a estratégia em que a batalha pela literatura greco-romana, e contra a resistência que esta despertava, se concentrava na pertinência dos Studia Humanitatis para a virtude cristã, restringindo-se ao terreno de concórdia entre clássicos e cristãos e silenciando-se prudentemente sobre os dogmas, liturgia, tradições e complexos aspectos confessionais ${ }^{228}$.

E nos parece esta uma questão crucial que, evitada por Petrarca, estava ainda muito distante de ser respondida, a julgar a formação, hábitos e possibilidades normais de qualquer eclesiástico de província no Norte europeu retratado sem perdão pela pintura de Hieronymous Bosch. É preciso lembrar que longe da iluminada e mediterrânea

\footnotetext{
${ }^{227}$ Idem, p. 129: "Quid enim, per Cristum obsecro, quid cristianum ibi, et non potius humanum omniumque gentium comune? Quid enim nisi dolor ac gemitus et penitentia in extremis (...) ? At nusquam ibi Cristi nomem expressum quod, superis licet atque inferis sanctum ac terribile, illis tamen in literis non habuit locum, obstante temporum ratione; nullus ibi fidei articulus, nullum Ecclesie sacramentum, deninque nichil evangelicum, nichil omnino quod non in caput hominis multa experti iamque ad finem experientie festinantis secundum naturale ingenium atque insitam rationem possit ascendere: quibus utinam non ab illis atque allis sepenumero vinceremur ! Potest errorem ac peccatum suum recognoscere et perinde erubescere ac dolere homo etiam non cristianus, fructu quidem impari, penitentia autem pari. (...) Quanvis ergo cui et qualiter confitendum sit nemo nisi cristianus noverit, tamen peccati notitia et conscientie stimulus, penitentia et confessio comunia sunt omnium ratione pollentium."

228 Idem, p. 131.
} 
Itália, o medievo prolongava ainda suas sombras nestas terras setentrionais onde se vivia ainda em uma Gothische Zimmer ${ }^{229}$ e as alternativas aos fantasmas pecaminosos do imaginário religioso popular eram o estudo e envolvimento em uma religiosidade hermética e ocultista com pretensões à manipulação do transcendental ou em uma radicalidade mística na busca desesperada da salvação pessoal pregada por movimentos religiosos dentro da própria Igreja - como a austera e intolerante Devotio Moderna ou o milenarismo messiânico - ou na busca sublimada em forma de literatura, poesia ou música em alguns poucos casos particulares, como o de Hildegard von Bingen, que não deixou também de sugerir algum ocultismo. Caberia a Erasmo avocar para si a tarefa de fundamentar a vantagem da doutrina cristã mostrando, ao mesmo tempo, como exatamente as disciplinas pagãs e a doutrina cristã confluem na unidade da verdade; esta e outras questões filosóficoteológicas ainda não respondidas cabalmente pelo humanismo.

${ }^{229}$ D’Ascia, Luca; op. cit., pp. 7 e 8. Com a expressão alemã 'Gothische Zimmer' - quarto gótico - o comentador faz associação entre o ambiente místico em que estudou o jovem Erasmo e as pinturas de Bosch. De fato, neste período da história da pintura as figura humanas eram retratadas apenas em ambientes fechados e se Bosch apresenta seus personagens em alguma paisagem, esta é antes uma paisagem onírica, visionária ou conceitual, distante ainda da busca da paisagem natural inaugurada pela pintura renascentista. 


\section{CAPÍTULO III}

\section{OS ANTIBÁRBAROS}

A explicação da afirmação de Petrarca "ninguém a não ser o cristão sabe a quem e de que maneira confessar" - cui et qualiter confitendum sit nemo nisi cristianus noverit - que todos intuíam, mas não sabiam explicar de maneira fundamentada, será oferecida por Erasmo no contexto de sua diatribe com os monges inimigos dos Studia Humanitatis e opositores em seu tempo da unidade da verdade - que se prevaleciam de um conhecimento cristão supostamente sagrado como garantia da superioridade e exclusividade da sua religião e da falsidade daquelas dos outros povos e, por analogia simplista, de todos os demais conhecimentos descobertos por estes, rejeitados e desprezados supersticiosa ou interessadamente como profanos e pagãos - propomos uma visita ao ainda pouco conhecido Antibarbarorum Liber ${ }^{230}$, título que traduzo por "Livro dos Antibárbaros”231, i. e, daqueles que são antibárbaros, que foi a primeira obra a ser começada por Erasmo e corresponde ao livro I, núcleo originário e único completo remanescente de uma série de quatro deixados infortunadamente com um depositário pouco zeloso. Na carta endereçada a Johannes Witz, adotada como prefácio à obra, Erasmo esclarece que no projeto inicial escreveu o livro I como refutação aos argumentos empregados contra os humanistas por certos autodenominados "religiosos” que seriam na

${ }^{230}$ Na edição de Opera Omnia aqui utilizada, i. e., a reprodução fotomecânica feita na Alemanha (Hildesheim, editora Georg Olms, 2001) daquela chamada “LB” feita em1703 e 1706 por Johannes Clericus em Leiden, os Antibarbaros são encontrados no Tomo X, entre as pp. 1691 C a 1744 E, incluindo a carta prefácio a Joanni Sapido.

231 “Antibarbarorum" (dos antibárbaros) é termo masculino plural com a declinação do caso genitivo que adjetiva "Liber" (livro) que está, por isto, no caso nominativo; então, literalmente, deve-se traduzir a expressão “Antibarbarorum Liber” por “o livro dos Antibárbaros”, i.e., "o livro daqueles que são antibárbaros”. No entanto, em alguns casos, ao se fazer a elípse da locução "livro do” provoca-se algum estranhamento quando se escreve, e. g.,: ”(...) neste sentido o Antibárbaros é uma enérgica resposta (...)” ou “ (...) a publicação do Antibárbaros em 1520 (...)” então proponho que nestes casos se acompanhe o uso italiano como em Luca D’Ascia, op. cit., p. 14. “(...) rassegnazione al destino, gli Antibarbari cercano di fondare (...)”, o uso francês como em Paul Jacopin e Jacqueline Lagrée, op. cit., p. 16. "Les lettres d'humanité, comme les appellent les Antibarbares, ou bien encore (...)” e o uso espanhol como em Halkin, op. cit., p. 85, “(...) Erasmo prepara uno de sus livros maestros - Los Antibárbaros - que (...)”, desde que o uso inglês desconhece a declinação do artigo "The" que pode introduzir, como sabido, tanto nomes no singular como no plural. Em conclusão, significando “o livro dos Antibárbaros” utilizarei a locução "os Antibárbaros” que não deixa também de ter apoio nos fatos, pois inicialmente a obra era composta por 4 livros dos quais, 2 se perderam e 1 foi parcialmente recuperado (Kumaniecki, Kazimierz, op. cit, p. 13). 
realidade supersticiosos e hipócritas; o livro II como ataque à retórica - vituperatio rethoricae - sob a máscara de seu inimigo colocando à prova sua eloqüência e atacando a própria eloqüência; o livro III como réplica a este ataque e o livro IV como defesa em separado da poesia ${ }^{232}$. Na primeira redação desta série, de caráter mais privado, entre 148889, seu autor tinha menos de vinte $\operatorname{anos}^{233}$ e estudava no monastério de Steyn, mas na segunda redação, entre 1494-95, já adquire vocação pública e é escrita em meio às viagens entre os Países Baixos e Paris; mesmo depois do extravio dos livros seguintes, a importância do livro I é confirmada pelas sucessivas inserções e correções - cujas estratificações espelham o próprio percurso intelectual do autor até a primeira publicação, em maio de 1520 na Basiléia pela editora Froben - e pelo seu grande êxito, provado pelas nove reedições identificadas até o falecimento do autor em $1536{ }^{234}$.

O livro I integra um projeto editorial que faz do autor o primeiro humanista a empregar a técnica do diálogo no norte da Europa e a opção pelo modelo declamationes in utramque partem, no qual se expunha os prós e os contras de uma determinada tese, o coloca em clara convergência com o movimento italiano do primeiro Quattrocento e o vincula especialmente a Lorenzo Valla, de cujas obras havia lido certamente o De vero falsoque bono, onde são opostas teses estóicas e epicureanas na busca de uma síntese cristã, e de quem sobretudo assimila a característica indignação e verve além da escrita direta e sugestiva, marca dos humanistas italianos, sem pedantismo nem esquematismos lógico-demonstrativos típicos dos escolásticos. Neste livro I especificamente, é apresentado um diálogo histórico-narrativo, claramente decalcado do De Oratore de Cícero cuja força - vis - e acrimônia são reproduzidas em uma simulação de debate público em que teses são contrapostas em meio a um grupo de pessoas; diálogo que

\footnotetext{
${ }^{232}$ Desiderii Erasmi, LB, X, op. cit., 1691 E e 1691 C.

${ }^{233}$ Idem, 1691 E. Neste trecho da carta a Johannes Witz - Joanni Sapido - o autor confessa que ainda não tinha 20 anos quando se pôs a trabalhar nesta obra - Nondum annum vigesimum attingeram, cum hoc operis sum aggressus.

${ }^{234}$ D’Ascia, Luca; op. cit.., p. 47. Na edição ASD, ainda em andamento, da Opera Omnia de Erasmo, a devassante introdução aos Antibárbaros, traz informações mais acuradas: “Antes de 1930, i.e., até o aparecimento de The Youth of Erasmus de Albert Hyma, o curto trabalho de Erasmo Antibarbarorum líber primus, era conhecido exclusivamente na sua segunda versão, que era a versão final como escrita pelo autor entre 1518-1520. Esta foi primeiramente impressa por John Froben na Basiléia em Maio de 1520 e reeditada nove vezes [em um total, portanto, de dez edições] durante a vida de Erasmo. Em 1930, Hyma publicou a versão original do manuscrito de Gouda [localizado por P. S. Allen na biblioteca municipal desta cidade] que foi escrito em Halsteren na primavera de 1494 ou 1495” (Kumaniecki, Kazimierz, op. cit, p. 7).
} 
evolui no sentido de uma oratio continua do personagem principal "Batt", verdadeiro porta-voz do autor, que ainda tem muito em comum com a biografia de Valla, pois é um poeta que não passou pelos estudos escolásticos, mas que possui, no entanto, uma grande erudição patrística e resolve sagazmente sutis questões exegéticas e de teologia. Esta circunstância é o artifício literário que Erasmo encontra para apresentar através deste personagem, um intelectual de tipo novo - renascentista - que exige o direito de tratar destas questões enquanto laico sem se deixar intimidar pelo tecnicismo da fraseologia escolástica e apoiando-se no humus de cultura clássica comum a escritores cristãos e pagãos, i. e., defendendo o conceito geral da unidade de teologia e "poesia”, como era chamada a cultura literária, e a aspiração a renovar aquele tempo antiquíssimo no qual os primeiros filósofos eram também teólogos e poetas ${ }^{235}$.

Talvez a partir da experiência monástica que mostra a Erasmo a oposição entre duas formas de vida comunitária - uma submetida a normas exteriores e rígida disciplina e outra marcada pelo livre compartilhamento de descobertas culturais e sociais sobre a base da igualdade e de um humor refinado e urbano no interior de um cenáculo humanístico - os primeiros manuscritos dos Antibárbaros, que testemunham o inconformismo de um jovem que se dizia perseguido pelo destino, evoluem para a proposição de um lúcido e coerente programa de reforma da educação que, consciente do afastamento da Antigüidade e da decadência e barbárie do presente, integra um projeto de renascimento da literatura clássica ${ }^{236}$ e do cristianismo dos Pais da Igreja fundado no esforço concorde da comunidade cultural internacional, a respublica litterarum. É neste sentido que Erasmo deverá responder aos defensores da “santa ignorância” que desprezam com radicalismo os autores antigos sem conhecê-los; apresentar a condenação da cultura profana como uma patologia social - possível apenas nos estratos mais baixos e incultos e como uma posição religiosa de boa fé, se bem que equivocada e rigorosa demais; acusar

\footnotetext{
235 Idem, op. cit., pp. 7 a 76.

${ }^{236}$ Para Halkin (op. cit., p. 85) os Antibarbaros propõem especialmente a união da sabedoria antiga ao cristianismo: "Desde então, Erasmo prepara uma de suas obras primas - Os Antibarbaros - que não é outra coisa senão a apologia da literatura profana, nada menos que o manifesto do humanismo cristão pela união entre a sabedoria antiga e a cristã. Como Petrarca, quer regenerar o homem batizando sua cultura e purificando sua religião”.
} 
os detratores das letras como detentores de uma posição de privilégio e contra quem se deve definir uma ética do estudo e da aprendizagem; proclamar com clareza o direito e dever dos doutos de desenvolver o próprio trabalho em uma esfera diferente da religiosa ${ }^{237}$ e a autonomia da cultura clássica laica livre da censura dos teólogos conservadores e pregadores ignorantes; propor que o estado deve assumir a supervisão da escola, licenciar os mestres ignorantes, abrir as portas aos jovens de formação clássica, reforçar o poder civil e o clero secular privando os frades da principal fonte de sua autoridade sobre a população, a educação escolástica e a predicação.

Deste modo, os Antibárbaros são à primeira vista um escrito antimonástico que traz propostas concretas para políticas educacionais, mas este caráter e propostas são apenas conseqüências de um premente debate teórico no qual se defende a metodologia humanística com a contestação pontual de argumentos doutrinários, do senso comum e, em especial, bíblicos empregados pelos chamados bárbaros para a condenação do saber profano ou para a sua rígida subordinação à ortodoxia, o que faz que este texto seja também um crucial escrito exegético. Mas aqui se chega à marca distintiva desta obra e ao seu real valor para nosso estudo: entre os escritos erasmianos, os Antibárbaros é o lugar onde essencialmente a exegese bíblica é mobilizada, quase ao exaurimento, para a definitiva defesa renascentista de toda a cultura - bona littera - incluindo as questões filosóficas e científico-abstratas - como valor humano compatível com o cristianismo, e para a proposição humanística fundamental de que a razão natural do Homem é capaz de obter resultados que, sem perder sua validade em campo específico, podem ser integrados à fé; defesa e proposição que, se verá, utilizam argumentos que acabam por levar o discurso ao extremo limite laico compatível com a posição religiosa. No seu longo amadurecimento entre 1488 e 1520 os Antibárbaros conservarão seu caráter de manifesto e realizarão o compêndio da completa concepção erasmiana do valor da cultura e da intima e estreita relação entre a doutrina cristã e o saber profano, testemunha e prova da unidade da verdade.

\footnotetext{
${ }^{237}$ Ivan Lins, op. cit., p. 190, faz em 1967 uma saborosa avaliação prática dos Antibárbaros: "Em 1518 sai, pela primeira vez, o Antibarbarorum Liber, (...). Foi um livro de imensa repercussão en tôdas as rodas humanísticas, vazado sob a forma de diálogo (...). Apresenta essa obra ainda grande interêsse para o Brasil, de vez que ainda há quem discuta entre nós se o ensino deve, ou não, ser leigo. Quanto a Erasmo, há 448 anos, já não tinha dúvida: era pelo laicismo (...)”
} 
Em busca de conteúdos propriamente filosóficos, devemos lembrar que Erasmo, interessado apenas nos assuntos humanos como Sócrates e atento para o dualismo fundamental apontado por Platão - entre retórica como arte sofística do engano no Górgias e a hipótese de uma linguagem que torne possível mesmo a comunicação com os deuses no $\mathrm{Fedro}^{238}$ - lança mão do tesouro de Minerva guardado por esta arte para empregá-lo sempre a serviço da verdade e do seu compartilhamento. Por este antigo critério platônico, Erasmo no seu Antibárbaros escreve como filósofo, mas sua escrita, até onde a exploramos, é sombreada como o entardecer para um olhar cientificista - treinado por séculos de exercício no método cartesiano e habituado a textos voltados apenas para a rigorosa compreensão intelectual, desde que ainda crentes na objetividade das idéias claras e distintas - e não são freqüentes nesta sua obra os pontos onde os temas da filosofia sejam tratados diretamente e sobre os quais sua pena incida sem fazer qualquer sombra como a luz meridiana, tal como, já no início dos Antibárbaros, o autor revela uma clara e definida concepção de história que enfatiza a liberdade humana e compreende a ação de uma Providência Divina na história que dispõe o cultivo das disciplinas profanas pelo homem como meio útil e complementar para sua salvação ${ }^{239}$.

Em consonância com as novas idéias vindas da Itália, o autor não aceita a concepção do eterno retorno do tempo, a linha temporal cíclica como os gregos e romanos pensavam a eternidade, com a reincidência incansável não dos fatos, mas das leis eternas que determinam os indefinidos ciclos de nascimento, morte, fundação e destruição das cidades, guerra e paz e etc.; também não advoga que os fatos confirmem a linha reta agostiniana do caminhar irrefreável dos decaídos filhos de Adão rumo à salvação nem ao contrário antecipa como fará J. J. Rousseau propondo que a história dos homens é a história da queda, um processo de desnaturação e que seu percurso é o da perdição e do constante

\footnotetext{
${ }^{238}$ D’Ascia, Luca; op. cit., p. 36.

${ }^{239}$ Erasmo da Rotterdam, Antibarbari, op. cit., p. 136. Nesta edição italiana, o trecho em que é avançada esta proposição recebe o subtítulo “Os pagãos cultivaram as ciências e as técnicas por causa da Divina Providência para que a usássemos, não para que a desprezássemos” - I pagani hanno coltivato scienze e tecniche per volere della divina provvidenza, perché ne facessimo uso, non perché le disdegnassimo" - mas prefiro evitar aqui o uso da expressão em português "as ciências e as técnicas” e traduzir a frase latina "disciplinas ab ethnicis expolitas” por “disciplinas aperfeiçoadas pelos pagãos”, por ser menos afeta a anacronismos, como consta do subtítulo original: "Divino Consilio disciplinas ab ethnicis expolitas, ut nos utemur, non ut contemneremus” em Desiderii Erasmi, LB, X, op. cit., 1712 C.
} 
declínio; também não tem esperanças como terá Voltaire para quem a história, mesmo com sobressaltos e alguns retrocessos sempre possíveis, será a trajetória da civilização, a realização nas sociedades humanas dos valores estabelecidos pela razão ${ }^{240}$ ou é otimista como será Condorcet em relação à Filosofia das Luzes, que acreditará que o seu século XVIII é a ocasião em que definitivamente a história do gênero humano se liberta da obscuridade e da ignorância, pois o sistema geral dos conhecimentos humanos, o método de descobrir a verdade torna-se na sua época uma arte que se pode aprender e a razão encontra seu caminho para sempre ${ }^{241}$. É preciso lembrar que o mestre está muitas vezes distante de teses características do que se chama atualmente “humanismo" e remetem a posições ulteriores tais como a confiança completa no Homem, a fé no progresso histórico da humanidade, o elogio das Luzes, o poder ilimitado da razão do homem, a vocação prometeica do Homem, etc. ${ }^{242}$.

E de fato, os Antibárbaros apresentam antes de tudo um quadro sinistro da história através do personagem “Batt”, real porta-voz do autor, que aponta o tempo que se seguiu à Antigüidade clássica como época de profunda decadência e acusa o contraste entre o fulgor do passado e a mediocridade contemporânea nas seguintes linhas:

“(...), como acontece nestas conversas soltas onde se passa de uma coisa à outra, começamos a falar mal do nosso tempo, algo previsível, mas não sem razão. Nos perguntávamos com estupor qual teria sido a assustadora catástrofe responsável pela dispersão do patrimônio cultural da Antiguidade, tão florescente e exuberante; que terrível inundação teria arrastado consigo, em horrível confusão, os textos clássicos de um período tão puro e ordenado. Como podíamos ser assim tão inferiores aos antigos? Os mais cultos entre os nossos contemporâneos, com um par de exceções, podiam apenas medir-se nas competições literárias com as mulheres gregas e romanas ou com as crianças do ensino

\footnotetext{
${ }^{240}$ Equivoca-se ao se atribuir à Renascença, em seu resgate da dignidade do Homem frente ao medievo, uma anacrônica confiança na razão humana, pois a dignidade do Homem é pensada antes como liberdade e não como mérito intrínseco de sua razão natural que pode mesmo se perder sem os estudos das humaniores litterae.

${ }^{241}$ Souza, Maria das Graças de, op. cit., pp. 8 a 10.

242 Jacopin, Paul, Lagrée, Jacqueline; op. cit., pp. 4 e 10.
} 
elementar. Os generais de hoje não seriam tomados nem como soldados simples. Os timoneiros de hoje não seriam embarcados nem em navios atracados”. ${ }^{243}$

Como famulus $^{244}$ que teme desapontar seu mestre, devo tratar sua obra sem cair na tentação das mais atraentes de apenas sumarizá-la ${ }^{245}$, então é preciso arriscar que Erasmo não é apressado, vide interessado, em propor, descrever uma verdade sobre a história dos homens que os torne condicionados ou diminua em qualquer sentido sua liberdade. Talvez mesmo achasse inútil a pergunta pela possibilidade da história determinar os homens, desde que qualquer resposta estaria sujeita à controvérsia, ou a achasse mesmo perniciosa, pois sua prioridade como filósofo da moral, não é apenas possuir um conhecimento enciclopédico das tentativas de responder aos problemas fundamentais do Homem como faria um autor restrito à erudição $0^{246}$, mas propor um conhecimento ${ }^{247}$ que mostre e reivindique sua dignidade ampliando a percepção de sua responsabilidade sobre suas ações ao invés de justificá-las, explicá-las externamente através da pressuposição de entidades como o “eterno retorno”, “eternidade”, “desnaturação”, “progresso”, “razão” ou

${ }^{243}$ Erasmo da Rotterdam, Antibarbari, op. cit., p. 87, em tradução que proponho.

${ }^{244}$ Erasmo dispôs de secretários particulares e auxiliares, Famuli, freqüentemente mais interessados em ouvilo que recompensados em pagamento. Vide verbete "Famille”, p. CX do dicionário incluído na coletânea R. Laffont: "Seguem-se os famuli, rapazes mais velhos, em geral estudantes que fazem seus estudos junto aos seus mestres (...) alojados, alimentados e vestidos, mas sobretudo educados e instruidos pelo mestre. Erasmo quer que eles sejam bons latinistas e bons copistas. Eles transcrevem cartas e as escrevem quando o mestre adoece. Eles se tornam ocasionalmente corretores dos trabalhos nas tipografias (...)“. Erasmo dispunha também de 'puer' que são "geralmente considerados antes como pequenos auxiliares que criança que se deve instruir por aquele que a emprega" e de "convictores" que curiosamente "pagam uma pensão mensal e que fazem um certo número de trabalhos domésticos. Entre estes hóspedes pagantes, se pode citar o alemão Arnoldus, secretário de Maximiliano e Charles V (...) ”.

${ }^{245}$ É necessário repetir aqui o alerta sobre os inúmeros perigos a que se expõe quem trata escolasticamente a obra de um humanista, decantando incessantemente os mesmos conceitos, resumindo, dividindo e subdividindo indefinidamente, procedimento que, exagerado, equivale para estes à barbárie por ignorar o preceito "que seja observado o comedimento na divisão do tema" - Paucitas in partitione servatur - proposto por Cícero no De Inventione, op. cit., p. 48, que a rigor não o segue exatamente, ao menos neste livro didático escrito na sua juventude e incansavelmente lido durante todo o Medievo. Outro alerta é dado pelo próprio Erasmo em Antibarbari, ao tratar das honoráveis 'summae', que desqualifica em algumas linhas: "Nos debruçemos pois sobre a summa de Santo Antonio, sobre a summa Pisana, sobre a summa Astesana, sobre a summa Angelica e consultemos todos os outros autores e até os simples compiladores: todos os textos são do mesmo teor e, por assim dizer, todos os salmos terminam em Gloria. De fato, os escritores deste tipo adotam todos o mesmo método: não afirmam nada de original, mas metem juntos as afirmações de vários autores, antologizados de maneira desordenada e não só discordantes, mas às vezes mesmo contraditoriamente. Satisfeitos pela sua compilação, deixam ao leitor a responsabilidade de julgar.” (op. cit., p. 184).

${ }^{246}$ Uma crítica vulgar, que se faz aos humanistas, os acusa de interessar-se apenas na pura e descomprometida erudição.

${ }^{247}$ Estaríamos muito distantes da verdade se em Erasmo, ao invés de falarmos da "busca” do conhecimento a respeito do homem nos moldes da filosofia da natureza devessemos falar da proposição de um conhecimento do homem sobre si mesmo conforme o programa humanístico moldado pela obra de Cícero ? 
qualquer lei histórica ou entidade proposta pela ciência ${ }^{248}$; inclusive suponho que lhe causaria estupor a idéia de uma "força das coisas"249 que arrastasse os homens inexoravelmente para seu bem ou para seu mal como as temíveis fúrias; como se não bastasse a aceitação da submissão do Homem às leis divinas e fosse necessário criar mais uma instância abaixo dos deuses, mas igualmente determinativa e sobreposta à condição humana. Com certeza, ao mestre não escapava o natural conflito teórico entre a reivindicação ética, apenas possível no campo da liberdade de escolha da ação e qualquer possível filosofia da história que limitasse esta escolha. Não sem motivo, portanto, as primeiras claras proposições filosóficas que comparecem nos Antibárbaros são trazidas por três dos cinco personagens em debate que apresentam suas teorias explicativas da história como determinação externa ao homem, logo seguidas da oposição taxativa do personagem "Batt”, alter ego de Erasmo: o médico José afirma primeiramente suas convicções astrológicas:

"O médico atribuía toda a culpa às estrelas. Sabia falar bem, mas tinha uma paixão pela astrologia. Com ela explicava tudo, mesmo sendo um bom cristão e homem cultivado. Exemplificava a sua tese com muitas observações agudas e até convincentes: a vicissitude das coisas humanas depende dos astros, são eles que fazem

\footnotetext{
${ }^{248}$ Agostinho, A Trindade, op. cit.., Livro XIV, p. 438. Em Erasmo, a implícita condenação das especulações das ciências que tomam toda e qualquer das coisas humanas como seu objeto - no sentido aristotélico - o aproxima da posição de Agostinho que faz a crítica da curiosidade deste tipo de ciência: "Sobre a ciência, discorri no livro XIII. Por certo, não lhe atribuí tudo o que o homem pode saber de conhecimento das coisas humanas, pois aí há muito de superfluidade, que alimenta apenas uma vã curiosidade e nociva vaidade. Mas atribuí à ciência somente aqueles conhecimentos que geram, nutrem, defendem e fortalecem a fé soberanamente salutar, a qual conduz o homem à verdadeira felicidade”. Já antes, contra o puro saber enciclopédico, Sêneca se manifestara através de seu Ad Paulinum De Brevitate Vitae criticando os falsos ociosos que vivem permanentemente ocupados com seus desejos - Non sunt ociosi quorum voluptates multum negotii habent - e colocando entre estes os que se ocupam de “(...) de inúteis questões de literatura - eles já são multidão entre os romanos! Foi um vício dos gregos - Graecorum iste morbus fuit - investigar quantos remadores teve Ulisses, se a Ilíada ou a Odisséia foi escrita primeiro e, além disso, se eram de um mesmo autor (...) Pois mesmo que se admita que eles contam essas coisas todas de boa fé e que se responsabilizam pelo que foi escrito, contudo esses conhecimentos servirão para minorar os erros de alguém? Refrearão as paixões de alguém? Farão alguém mais generoso, mais corajoso, mais justo? - quem liberaliorem, quem fortiorem, quem iustiorem, facient? Às vezes meu caro Fabiano dizia duvidar se era melhor não empreender estudo algum do que se envolver com os deste gênero - an satius esset nullis studiis admoveri quam his implicari”. Sêneca - Sobre a Brevidade da Vida, São Paulo, Nova Alexandria, 1993, pp. 43 a 45 e 70 a 71.

${ }^{249}$ Souza, Maria das Graças de; op. cit., p. 197. A bela imagem da “força das coisas” criada por Saint Just é empregada pela autora para sugerir que as diferentes idéias iluministas de Voltaire e Rousseau se reúnem na obra e ação política de Condorcet, mas serão verdadeiramente realizadas e provadas pela Revolução Francesa: a instância prática parece possuir qualidades condicionantes próprias, não necessariamente permeáveis ao pensamento.
} 
nascer e morrer os impérios, que transferem a autoridade e o poder de um povo para outro, de uma família para outra, que transformam o espírito dos mortais induzindo-os a diversos costumes, disposições, interesses e fortuna. As estrelas tinham seu movimento regular, seu ciclo, mas exerciam influxos bem diferentes: algumas eram favoráveis ao estudo, outras hostis. Por conseguinte, segundo a natureza do astro dominante em um determinado momento, também a cultura na terra prosperava ou decaía. Recordou então as várias idades do mundo e as mudanças acontecidas entre uma e outra, despertando nossa admiração com a sua extraordinária memória” ${ }^{250}$.

Em seguida, intervém o cônsul apresentando uma interpretação da história que toma o homem como ser completamente determinado pelas instituições e suas ideologias:

“O cônsul disse que não era completamente em desacordo com o médico, mas que, segundo ele, haviam muitos indícios de que a religião fosse responsável pela decadência da cultura. Não avançava esta tese por falta de fé: era muito devoto. Acreditava, no entanto, que a religião tivesse oferecido um agradável pretexto para a ignorância e a barbárie. Os protagonistas do primeiro cristianismo não foram de fato os filósofos, os oradores, os dialéticos ou os matemáticos, mas sim o humilde Cristo e os Apóstolos que não eram pessoas de cultura. Os cristãos antigos detestavam as disciplinas profanas pensando que fossem inimigas de Cristo. Não conhecer a cultura clássica era um mérito. Ignorar a filosofia de Platão ou de Aristóteles equivalia a desprezar o poder, escarnecer a riqueza, depreciar a volúpia. A religião desvalorizou tudo aquilo que o paganismo profano admirava. Os cristãos ferventes, mas não sábios, arrastados pelo ardor da polêmica, não quiseram ter nada em comum com os adversários, mesmo ao custo de renunciar à grandes conquistas culturais. Ciência e literatura foram então descuidadas” ${ }^{251}$.

Finalmente, o amigo Willem Herman apresenta a hipótese de subordinação do Homem e sua história a uma determinação transcendental em tal grau fantástica que se assemelha a um mito primevo:

\footnotetext{
${ }^{250}$ Erasmo da Rotterdam, Antibarbari, op. cit., p. 88, em tradução que proponho.

${ }^{251}$ Idem.
} 
"Willem afirmou acreditar na velhice do mundo. Havia muitos indícios disto e escritores extremamente respeitáveis o comentavam. O mundo e tudo o que se gera no mundo tem um período de crescimento, um tipo de juventude. Depois, quando se alcança o cume do desenvolvimento, começa-se a envelhecer e a decair. Cibele, a Grande Mãe, estava se tornando estéril. Uma vez dava à luz os jovens deuses; agora, cansada dos partos, é muito se pode gerar homens. (...). Para resumir, enunciou a conclusão de que a inventividade dos modernos, nossos contemporâneos, é inferior àquela dos antigos e que estamos diante da velhice da natureza. Outrora, a natureza não produzia apenas corpos maiores mas também mentes mais brilhantes e viris. Agora, ao contrário, os homens não nascem apenas menores, mas também muito menos inteligentes. Por isto os antigos foram capazes de inventar, nós mal conseguimos com esforço compreender o que eles cogitaram. Eles sabiam conjugar cultura e eloqüência, nós no máximo aspiramos a uma das duas coisas separadamente e sem grandes resultados”,252.

Mas em um movimento decidido e seguro, Batt atribui esta decadência ao próprio Homem nas linhas imediatamente seguintes:

“Apreciei a argúcia e a eloqüência de vocês, mas não concordo com os julgamentos de vocês. Um coloca a culpa nas estrelas que não fazem mal algum. O outro condena a nossa excelente religião. O terceiro tira do bolso do colete nada menos que a velhice do mundo. Do meu ponto de vista vocês são todos muito injustos. Porque acusar as coisas? A culpa é dos homens! Se nós erramos, o reconheçamos, ao invés de procurar por toda parte o bode expiatório. Se não queremos assumir a responsabilidade dos males evidentes, por que não a atribuímos à divindade que segundo Homero preside o destino, à deusa Ate todas as desventuras da vida humana, como fazem na Ilíada Agamenon e Zeus? ” 253 .

A concepção de história do autor está então estreitamente vinculada, senão subordinada, a uma antropologia, a uma teoria sobre a condição humana que inclui e

\footnotetext{
${ }^{252}$ Idem, pp. 90 e 91. Talvez está aqui implícita uma crítica à separação entre eloqüência e sabedoria, i. e., e sua origem retórica.

253 Idem, p. 92.
} 
implica algum grau de liberdade. Este tema é tão caro aos humanistas e em especial para o autor que este - apesar do fato de ser o inspirador de grande parte das críticas à Igreja que se tornarão lanças nas mãos do reformados - ao perceber que se tornou politicamente incontornável a necessidade de escrever contra Lutero defendendo a Igreja Católica, se apegará ao essencial da doutrina tradicional cristã, que justamente se aproxima da posição pagã, escolhendo de propósito o tema da liberdade humana no seu livro De Libero Arbitrio de 1524. Este livro provocará a dura resposta de Lutero através do De Servo Arbitrio de 1525, polêmica que Erasmo procurará encerrar com seu Hyperaspistes neste mesmo ano. Mas além de recusar as determinações externas ao Homem ${ }^{254}$, o autor está alerta também contra as psicologisantes proposições de determinações internas :

“Os cristãos comuns se comportam do mesmo modo: se cometem algum erro por falta de lucidez, dizem que o diabo os seduziu e instigou. Se aceitamos este princípio, de agora em diante todos terão suas desculpas. O luxurioso se apegará à juventude, o avaro e sovina à velhice, o ambicioso à riqueza, o irascível ao temperamento bilioso. Deixemos os sofismas!"255.

Este argumento reproduz aquilo que já pensava o senso comum favorável a um conceito difuso e acrítico da liberdade humana e aquilo que pregava a tradicional exegese bíblica que aceita e pressupõe um grau desta liberdade, ao menos no sentido lato, conhecido de todos, compreensivelmente útil e desejável para reforçar talvez a espontânea tendência da sociedade em desenvolver a obediência a um código moral e a uma autoridade religiosa através da culpabilização e conseqüente responsabilização do homem pelas suas ações, essencial para fazer funcionar um sistema de justiça do além mundo baseado em recompensas e punições após a vida; mas este conceito medieval difuso, lato e instrumentalizado da liberdade aparentemente lembrado pelo autor e que tantas sociedades utilizam - como foi inclusive o caso da religião grega com o orfismo e suas derivações - é

\footnotetext{
254 A liberdade do Homem pensada pela Renascença é melhor compreendida no seu quadro teórico de origem que é a política como conhecida pelos antigos que separam os homens entre livres e servos e não talvez como imaginado por Burckhart em op. cit., a partir do quadro estetizante do século XIX que separa os homens entre os que se identificam e os que contrastam com a sociedade que integram, entre aqueles os que reproduzem em si a sociedade e aqueles que afirmam sua individualidade e se conhecem em oposição a ela.

${ }^{255}$ Erasmo da Rotterdam, Antibarbari, op. cit., pp. 92 e 93.
} 
apenas uma primeira aproximação do tema que o autor faz em favor da sua real posição teórica: durante um milênio, a rigorosa e pessimista consideração agostiniana que restringe a liberdade humana ao sentido stricto ${ }^{256}$ havia preocupado apenas pequenos círculos até que Petrarca em confronto com o tema inaugura a otimista posição humanista claramente favorável a um primeiro Agostinho ${ }^{257}$ que lhe pareceu expressar e testemunhar um grau deste sentido stricto de liberdade ao expor seus dilemas pessoais em Confessiones; esta posição em favor da liberdade em sentido forte que de alguma maneira corresponde às nascentes aspirações individuais e intelectuais da época ${ }^{258}$, será integrada ao programa geral do humanismo sem constituir-se em discurso filosófico único, e será assumida como essencial para a valorização e enaltecimento da dignidade do Homem ${ }^{259}$.

Esta visão da história que aponta a atual decadência de suas realizações e criações enquanto realça a responsabilidade do Homem é fixada nos Antibárbaros pelo exórdio - para o discurso que os demais personagens pedem que Batt faça em defesa da cultura clássica - que imita a oração que tradicionalmente entre os romanos um sacerdote,

${ }^{256}$ É o sentido em que Agostinho na sua maturidade trata da doutrina da Graça e da Predestinação.

${ }^{257}$ Kristeller, P. O., op. cit. p. 106. "Desta maneira, foi o Agostinho das Confissões, o homem que com eloqüência expressava seus sentimentos e experiências, e não o teólogo dogmático, aquele que impressionou Petrarca e outros humanistas posteriores, e os ajudou a reconciliar suas convicções religiosas com seus gostos literários e suas opiniões pessoais”.

${ }^{258}$ Burckhardt, Jacob, op. cit., p. 197. Este autor, no século XIX, inventando na prática o que hoje chamamos de "história da cultura" - Kulturgeschichte - também se celebrizou por intuir na Renascença o surgimento do moderno sentimento de individualidade: "A natureza destes Estados [italianos], que eles sejam republicanos ou despóticos, é a causa principal, senão única, do precoce desenvolvimento do italiano; é graças a ela sobretudo que ele se tornou um homem moderno. É ainda graças a ela que ele é o mais velho dos filhos da Europa atual. (...) O véu que envolvia os espíritos (...) fazia o mundo e a história aparecerem sob cores bizarras; quanto ao homem, ele não se conhecia a não ser como raça, povo, partido, corporação, família ou sob outra forma genérica ou coletiva. É a Itália que primeiramente rasga este véu e que dá o sinal para o estudo objetivo do Estado e de todas as coisas deste mundo; mas ao lado desta maneira de considerar os objetos se desenvolve os aspecto subjetivo; o homem se torna indivíduo espiritual, e ele possui consciência deste novo estado. (...). Já Lucièn Febvre em op. cit, p. 91, se posicionando contra a explicação reducionista que baseia a origem do movimento reformista do século XVI unicamente nos abusos da Igreja, ressalta que « O que é preciso ver ao menos, (...) é como, nos primeiros anos do século XVI, uma profunda necessidade de renovação moral e religiosa fazia sofrer, em todos os países da velha Europa, uma multidão mais ávida do que nunca por certezas. Raramente a humanidade teve mais nítidamente o sentimento de viver dias enebriantes de uma primavera cheia de promessas. (...) não desconheçamos a prodigiosa fecundidade de um século que tentou, precisamente, um esforço magnifico e quase desesperado para quebrar os quadros estreitos da Igreja e fundar sobre suas ruínas a infinita variedade de religiões livres (...) que Lutero não tinha conseguido satisfazer os desejos desenfreados por libertação que animavam os homens de seu país e de seu tempo, eis o que diz muito sobre o estado de espírito destas gerações. "

${ }^{259}$ Kristeller, P. O., op. cit. p. 243. Um exemplo é dado na p. 238 com Pico della Mirandola para quem "A dignidade do Homem está na liberdade de escolha porque as diferentes possibilidades que se abrem incluem as mais altas; o homem só alcançará sua dignidade plena quando escolher a possibilidade mais elevada”. 
pertencente ao colégio de vinte fecialis responsáveis pelas formalidades da política externa, fazia ao abrir em cerimônia a porta do templo de Marte dando início às hostilidades para com os bárbaros sempre que se iniciava uma nova guerra, segundo costume relatado por Livio. Este exórdio, que é uma oração contra os bárbaros, se inspira no proêmio que Valla antepôs ao primeiro livro de suas Elegantiae Latinae invocando a imagem da "guerra justa" contra os Galli que assediavam o Campidoglio para marcar vigorosamente o alinhamento do autor ao conceito valliano de ruptura ideológica radical com o Medievo, ainda mais incisiva que a proposta por Petrarca, como uma época de barbárie e de decadência ${ }^{260}$. É este o exórdio que imita a praxe romana :

"Com que direito, oh Godos, abandonais as vossas terras e não vos limitais a ocupar as províncias dos Latinos (i. e., as disciplinas liberais), mas tendes a audácia de desafiar a própria Roma, senhora do mundo (i. e., a língua latina)? Por que vos ofendestes? O que procurais? Se quereis a guerra, combatei segundo as regras, deixai-vos vir ao embate. Mas, se o embate vos atemoriza, parai de provocar-nos, andai-vos embora das nossas terras, evacuai esta região e permanecei no vosso território. Se preferis ser chamados de inimigos antes de bandidos, saí dos vossos esconderijos, começai o combate e coloquemos fim as nossas hostilidades em batalha aberta: se perdeis, acalmai-vos; se perdemos, reconheceremos a vossa vitória”, ${ }^{261}$.

Esta calculada imitação literária dos antigos fixa em imagem a nova visão de história associada à liberdade do Homem e exemplifica nas letras a geral atitude intelectual que marca o Renascimento de considerar a Antigüidade como um período outro, não mais como o mesmo que se vivia; esta imitação artificiosa, que é a valorização de um rito passado pelo seu conteúdo histórico e interesse para a erudição, indica e prova a própria alteridade de quem imita, a não continuidade daquilo que é imitado, o reconhecimento

\footnotetext{
${ }^{260}$ Idem, pp. 13, 16, 18, 25 e 26.

${ }^{261}$ Erasmo da Rotterdam, Antibarbari, op. cit., pp. 118 e 119, em tradução que proponho.
} 
tácito de que o período que é imitado não existe mais ${ }^{262}$. No entanto, esta visão crítica da história não pode ser confundida com a relativização contemporânea do valor de cada período, pois o época de ouro do nascimento de Cristo é a referência que se é mantém e inaugura o período da graça ${ }^{263}$.

De certo modo é este pensamento que, desde Petrarca na Itália do Quattrocento, com o lastro dos novos conhecimentos históricos e literários da Antigüidade e a crítica que se seguiu do legado medieval, impulsiona a crença de que a decadência está chegando ao fim e que se vive a aurora de uma época de renascimento: o novo conhecimento de que havia uma decadência já significava o início de sua superação. Logo este pensamento crítico sobre a história passada é cristalizada pelo esquema triádico antigüidade-decadência-renascimento que já surge como uma interpretação otimista, pois o associa a um ciclo de declínio e renascimento da virtude nos homens, e então à sua liberdade, pois este ciclo não era entendido como necessário na história humana, mas um

\footnotetext{
${ }^{262}$ Panofsky, Erwin, Renascimento e Renascimentos na Arte Ocidental, Porto, Editorial Presença, 1981, p. 159. "A distância criada pelo Renascimento privou a Antiguidade do seu caráter real. O mundo clássico deixou de ser simultaneamente uma possessão e uma ameaça, tornando-se, ao contrário, o objecto de uma apaixonada nostalgia, que encontrou a sua expressão simbólica na re-emergência - depois de quinze séculos dessa visão de encanto, a Arcádia. Ambos os Renascimentos medievais, independentemente das diferenças entre a renovatio carolíngia e a "revivescência do século doze”, estavam insentos desta nostalgia. Para eles, a Antiguidade (...) estava, por assim dizer, presente. O Renascimento veio a compreender que Pã tinha morrido - que o mundo da antiga Grécia e da antiga Roma (agora designada como sacrossancta vetustas) estava perdido, como no paraíso de Milton, e só no espírito poderia voltar a ser alcançado. Pela primeira vez, era o passado clássico olhado como uma totalidade separada do presente e, consequentemente, como um ideal a que se aspira em vez de uma realidade simultaneamente utilizada e temida". Remontando a Burckhardt em op. cit., Tomo II, p. 117, há uma passagem que merece ser lembrada menos por antecipar Panofsky que por fixar diferentemente uma mesma intuição: « Sem dúvida, é necessário acrescentar que a Idade Média foi subvertida pela Itália de então, e que o espírito podia estudá-la pois havia antes se libertado dela. Outra prova inequívoca dos novos tempo é lembrada por Francisco Rico em op. cit., p. 26 ao citar um trecho das Familiares, XXII, II, 20, de Petrarca que pode ser traduzido como segue: “(...) me agrada a imitação, não a cópia, e imitação mesmo sem exagero, na qual brilhe o engenho do imitador não a sua cegueira ou pobreza (...) - (...) sum quem similitudo delectet, non identitas, et similitudo ipsa quoque non nimia, in qua sequacis lux ingenii emineat, non cecitas, non paupertas (...)".

${ }^{263}$ Não podemos concordar com Luca D'Ascia quando este afirma que “Tudo isto deve ter sido incompreensível para quem ainda pensasse em termos de idades do mundo ou da Igreja ou da sucessão de monarquias universais” pois a Renascença ainda pensava com a medida de tempo da Igreja, como fazemos hoje, ainda que nominalmente (op. cit., p. 26).
} 
ciclo simplesmente dado de fato, resultado da soma de uma multidão de escolhas livremente feitas na historia ${ }^{264}$.

É neste quadro de uma nascente convicção na liberdade do Homem fazer sua história, que Erasmo avançará sua explicação sobre o real caráter da precedência do cristianismo resumida na frase petrarquiana “(...) ninguém a não ser o cristão sabe a quem e como confessar”; explicação que deverá atenuar ou mesmo romper o quadro em que a religião cristã - apesar de ter ultrapassado as fronteiras geográficas, étnicas e de classe como poucas religiões já haviam feito - se atribuía ainda o título de portadora única e exclusiva de uma revelação sobrenatural, i. e., da verdade sobre o Sumo Bem do Homem, referência para julgar e dispor de tudo o mais como sagrado ou profano reservando um destino obscuro aos não convertidos do presente e do passado e gerando um efeito segregacionista contido na locução adjetiva “povo eleito” com que se autodefinia, e ainda insinuado na frase petrarquiana acima. O real universalismo do cristianismo e sua conciliação com os Studia Humanitatis apenas seria possível com a ruptura deste quadro mental separatista através de uma nova interpretação teológica dos fatos da história e de uma nova interpretação também da história da filosofia - o que implica talvez em uma nova idéia filosófica a ser competentemente identificada - lastreada na tradição teológica que remonta à fundação da Igreja.

\footnotetext{
264 Não podemos concordar com a frase excessivamente otimista de Luca D’Ascia em op. cit., p. 14 : "Proclamando o retorno aos clássicos dever pessoal de todo douto e de cada educador e ironisando a fácil resignação ao destino, os Antibárbaros buscam fundar sobre o terreno de uma embrional 'filosofia da história' a instância psicológica da liberdade de escolha individual.” pois a noção de liberdade histórica presente no Antibárbaros é antes empregada para culpar o homem pela decadência que seguiu o período áureo do nascimento de Cristo. O otimismo do comentador parece deixar-se contagiar pela pressuposição burkhartiana de um precoce individualismo na Renascença. Também não acompanhamos Francisco Rico, em op. cit., p. 27, para quem “(...) a nova perspectiva que se abre agora, a partir de um amplo e crescente conhecimento da história, é a de uma noção de tempo que pode ser relativizado como sucessão de grandes períodos com diferentes méritos, cujo grau não depende necessariamente do período atual e pode mesmo, ao contrário, superá-lo” perspectiva que seria “(...) a conquista intelectual (...) o resultado mais alto dos Studia Humanitatis (...) entre os inumeráveis conceitos fundamentais que estes legaram (...) a descoberta - que hoje é senso comum - de que nossa dimensão é a história, a variação, a diversidade de ambientes, de experiências que implicam o relativismo e o desenvolvimento de programas de ação na certeza de que é possível mudar a vida, que o mundo pode ser corrigido". É preciso ter claro que o Renascimento, a rigor, não se voltava para o "novo" para o "futuro" e "as novas conquistas” que integram o trivial discurso sobre nossa própria época, mas antes a recuperação da glória, fortuna e conquistas passadas. Este olhar voltado sobre o futuro, talvez devamos procurar apenas no final do XVI em Bacon.
} 
Depois de um poderoso ataque - indignatio ${ }^{265}$ - contra os bárbaros de sua época - como chama os frades das diversas ordens, onipresentes na organização do ensino à época, que acusa de serem reacionários ao programa de estudos humanístico por ignorância ou conveniência sob o manto de religiosidade, Erasmo, sempre através do personagem Batt, assumindo o tom sóbrio e elevado na parte de seu discurso que parece ser a narração ciceroniana - a narratio ${ }^{266}$ - a parte importante da exposição da causa, faz esta ruptura daquele quadro mental apresentando as seguintes proposições:

"Quando me ponho a refletir sobre a admirável ordem das coisas e sua harmonia, me parece certamente, e às muitas e seríssimas autoridades, que não sem a Divina Providência, foi dado aos pagãos a descoberta das disciplinas. (...) De fato, o imortal governador do mundo, sendo a própria Sabedoria, constituiu o universo na forma mais racional, regulando as mudanças e as diferenças segundo a sucessão mais conveniente, introduzindo a ordem mais adaptada, de modo que tudo tenha com tudo a melhor relação e nada, nesta tão imensa variedade de coisas, se verifique casualmente. A este século de ouro que designou para nascer, quis que todas as épocas passadas e seguintes servissem e trouxessem em acréscimo a este único as soluções e conveniências obtidas da natureza das coisas: pois estava prometido que Ele seria perfeito" ${ }^{267}$.

“E onde está aquela harmonia das coisas pela qual, como afirma Santo Agostinho, nem o mal seja visto como criado inutilmente? O que então, desde o início do mundo, tantas figuras, prodígios e mistérios esperavam a não ser o século cristão? Por que

\footnotetext{
${ }^{265}$ Cícero, op. cit., p. 116. O ataque - indignatio - é a parte do discurso pela qual nos chegamos a provocar um ódio violento contra um homem ou graves prevenções contra um fato - Indignatio est oratio, per quam conficitur ut in aliquem hominem magnum odium aut in rem gravis offensio concitetur.

${ }^{266}$ Idem, pp. 31 e 41 . A narração - narratio- é a parte do discurso que segue ao exórdio - exordium - e faz a exposição da causa de maneira breve, clara e verossímil.

${ }^{267}$ Desiderii Erasmi, LB, X, op. cit., 1712 C, "Quinimo admirabilem rerum ordinem \& harmoniam quam vocant paulo penitus introspicienti, videri mihi prorsus solet, nec mihi adeo soli, visum est idem \& plerisque gravissimis Auctoribus, non sine divino consilium disciplinarum inveniendarum negotium Ethnicis datum esse. Immortalis enim ille rerum moderator, ut est ipsa sapientia, ratione summa constituit universa, pulcherrima quadam vissitudine distinguit, aptissimo ordine digerit, ut omnibus omnia miro quodam modo respondeant, nec qucquan in tam immensa rerum varietate ferri temere sinit. Hic aureo illi seculo, quo nasci decreverat, voluit ut omnes \& anteactae \& sequuturae servirent aetates, ad hujus unius felicitatem decusque cumulandum quaecunque in rerum natura essent, referre placuit: quod ipsum se perfecturum pollicebatur.
} 
então toda a Lei de Moisés, tantos ritos, cerimônias, atos sacros, promessas e profecias? Paulo não é testemunha que tudo isto prefigurava a vinda deste século? “ 268.

“Com tudo de valoroso feito pelos pagãos, afirmações acuradas, engenhosas cogitações, diligentes exposições, Cristo preparava a sua República. A eles dera o engenho, acrescentara o ardor pelo estudo e estes, não através de outro autor, encontravam o que procuravam e reuniram em sua época esse gênero de riquezas não tanto para si, mas para nós (...)”269.

”A diversidade e a contrariedade dos fenômenos se resolve em uma harmonia superior. O fim das coisas individuais coincide com aquele do todo. Cristo, portanto, ótimo governador do mundo, tendo destinado ao seu século o conhecimento do Sumo Bem opinou por destinar aos séculos anteriores o segundo maior bem de todos que é a suma erudição. De fato, o que há de melhor que o homem possa alcançar com as suas próprias forças que o conhecimento da suma erudição? Assim, Deus quis poupar-nos fadiga, ou melhor dizendo, deixar-nos tempo livre para outras tarefas, pois boa parte do trabalho os pagãos já a fizeram.”270

Em um movimento seguro e rápido, na velocidade de alguns parágrafos, Erasmo responde à pergunta-limite por que "ninguém a não ser o cristão sabe a quem e como confessar” através de uma articulação entre a historia antiga judia e pagã, o surgimento do cristianismo e os períodos seguintes, medieval e contemporâneo seu, que estabelece em termos novos a primazia do período que viu o nascimento do cristianismo.

\footnotetext{
${ }^{268}$ Idem, 1712 D. "Et ubi est illa rerum harmonia, qua fit divo Augustino, ut ne mala quidem otiose creata videantur? Quorsum ab ipsis Mundi rudimentis tot figurae, tot prodigia, tot mysteria spectabant? nempe ad seculo Christianum. Quid deinde tota Lex Mosaica, tot ritus, tot cerimoniae, tot sacrorum genera, tot promissa, tot oracula? nonne Paulo teste, haec omnia figurae contigebant illis ?

${ }^{269}$ Idem, 1713 A, “Omnia Ethnicorum fortiter facta, scite dicta, ingeniose cogitata, industrie tradita, suae Reipublicae praeparaverat Christus. Ille ministraverat ingenium, ille quaerendi ardorem adjecerat, nec alio auctore quaesita inveniebant. Hanc artium frugem illorum aetas tulit, non tam sibi quam nobis (...) “

${ }^{270}$ Idem. "Summa in rebus discordia, sed qua nihil concordius. Eodem feruntur \& singula \& universa, eodem spectabant, ad unum quiddam tendunt. Optimus igitur ille moderator Christus cum suo seculo summi boni cognitionem peculiariter destinasset, proximis ante seculis id tribuendum putavit, quod ad summum bonum proxime accederet, summam videlicet eruditionem. Quid enim secundun virtutem potest homini praestabilius contigere scientia ? qua quindem in re Deus Christianorum sive ignaviae, sive mavis otio consultum voluit, ut qui essemus aliunde occupandi, bonam laboris partem adimeret.”
} 
Termos que superam o tradicional quadro mental excludente e, ao invés de separarem os cristãos dos pagãos e dos judeus e justificar os preconceitos costumeiros, colocam os três no mesmo plano em que igual e humanamente buscam conhecer o Sumum Bonum e são apenas diferentemente bem sucedidos: aos judeus antigos foi antecipado o seu conhecimento, mas apenas através de signos, como é o caso da Lei mosaica e regras que são obedecidas sem serem compreendidas; aos pagãos que também procuraram através da filosofia aquele Bonum é atribuída a Sumam Eruditionem através da descoberta das disciplinas com o melhor uso possível das próprias forças humanas, e apenas aos cristãos o conhecimento do Sumum Bonum foi revelado plenamente através da vinda de Cristo. Mas está claro que se esta articulação evidencia que os signos dos antigos judeus estão superados pela revelação de seus significados pelo cristianismo, esta também coloca os cristãos em relação possível, conveniente, útil, e até desejável senão necessária com os pagãos, merecedores do segundo maior dom divino. Está claro também que esta articulação utiliza a idéia socrático-platônica do Sumo Bem, uma inquestionável categoria do pensamento filosófico para o entendimento da Revelação cristã, não o contrário, e que se busca provar que para além do indefinido desdobramento histórico de regras e imagens da religião cristã há algo essencial, há a razão e a invenção de disciplinas, um valor para o entendimento, o que é uma exigência típica da filosofia.

E também deve ficar claro que Erasmo propõe a proeminência do cristianismo como resultado da clara hierarquização dos diferentes períodos históricos de acordo com o tipo de relação que possuam com a idéia platônica do Sumum Bonum justamente nos Antibárbaros, que é seu livro marcado pelo esforço definitivo em entrelaçar as disciplinas pagãs ao cristianismo - e o faz expressamente no trecho do discurso de Batt que recebe o subtítulo "Pela Divina Providência as disciplinas foram descobertas pelos pagãos para que fossem usadas por nós e não para que as desprezemos" - "Divino Consilio Disciplinas ab Ethnicis ${ }^{271}$ Expolitas, vt Nos Vteremvr, Non vt Contemneremvs” - que parece sinalizar o núcleo teórico de onde serão extraídos à exaustão os argumentos que

\footnotetext{
${ }^{271}$ Érasme de Rotterdam, Éloge de la Folie, op. cit. Na sua nota 414 o tradutor nos informa sobre a palavra latina Ethnicis como utilizada por Erasmus: « Assim, se nomeia nos Atos dos Apóstolos XIII, 46, aqueles que estão fora da Igreja. ». Não se aplica imediatamente, portanto, com o sentido atual de "estrangeiros" sugerido pelo uso cotidiano das palavras “etnia” e “étnicos”.
} 
refutam as objeções aos Studia Humanitatis. Esta articulação vazada em termos da tradição filosófica parece ser a proposição teológica mais poderosa que Erasmo pôde agenciar em favor da causa humanista; foi inserida como caput, em forma lapidar e concentrada como seus adágios, para ser desdobrada em diferentes cadeias de razões que é preciso conhecer.

Senão, vejamos: percebemos de imediato a proposição teológica de que foi a Divina Providência que deu aos pagãos a tarefa de descobrir as disciplinas no propósito de que cada época contribuísse com suas conquistas e comodidades para a época de ouro que Cristo designou para nascer - Hic aureo illi seculo, quo nasci decreuerat, voluit ut omnes \& anteactae \& sequuturae servirent aetates - e assim, com tudo de valoroso feito pelos pagãos - ad hujus unius felicitatem decusque cumulandum quaecunque in rerum natura essent, referre placuit - as afirmações acuradas, engenhosas cogitações, diligentes exposições, Cristo preparava sua República - Omnia Ethnicorum fortiter facta, scite dicta, ingeniose cogitata, industrie tradita, suae Reipublicae praeparaverat Christus o que parece confirmado pela bíblia onde Cristo afirma que quando for exaltado trará para si todas as coisas - cum exaltatus, fuero a terra, omnia traham ad me ipsum - e é apoiado pela compreensão teleológica de uma natureza em que a admirável ordem das coisas e sua harmonia são constituídas para a realização de um fim, de maneira que tudo corresponde maravilhosamente a tudo, e em meio a tão imensa variedade nada é permitido acontecer por acaso - ut omnibus omnia miro quodam modo respondeant, nec qucquan in tam immensa rerum varietate ferri temere sinit - por autoridades teológicas como Agostinho que afirmou que nem o mal parece ser criado inutilmente - ne mala quidem otiose creata videantur pelo próprio encadeamento dos fatos históricos, no qual a translação de poder fez com que o cristianismo se beneficiasse da fundação de Roma para mais facilmente emanar para as demais partes da terra como se difundisse da cabeça para os membros - ut jam nata Christiana Religio, facilius in singulas terrarum partes dimanaret, si ab eodem capite tanquam in membra diffunderetur - pela própria natureza onde cada fase tem seu valor para o todo e cuida para que nenhum período flua inutilmente - dilligenter cavisse naturam, ne qua portio temporis inutilis effluat - e até pela observação da geografia desde que nem toda região produz tudo - non quaevis Regio supendiat omnia. 
A estes argumentos mais amplos são acrescentados outros que tratam do valor em si das disciplinas, pois foi o próprio Cristo que dotou os pagãos com engenho e lhes acrescentou o ardor pelo estudo e assim, não através de outro autor, i. e., o próprio Cristo, encontravam o que procuravam - Ille ministraverat ingenium, ille quaerendi ardorem adjecerat, nec alio auctore quaesita inveniebant - pois não há outra razão compreensível para a quantidade do que foi inventado com tanto sacrifício - quantus sudor - a não ser que estes esplêndidos estudos sirvam para enobrecer e sustentar ${ }^{272}$ a religião perfeita - Quorsum tandem haec omnia (...) an potius ut optima Religio pulcherrimis studis tum honestaretur, tum fulciretur? - pois, observando as grandes vantagens que as disciplinas e a enorme erudição pagã trouxeram e trazem ${ }^{273}$ para os cristãos, pode-se concluir que esse gênero de riquezas que a época pagã reuniu não foi tão útil para si quanto são para nós (...) Hanc artium frugem illorum aetas tulit, non tam sibi quam nobis (...) pois os pagãos também trataram de assuntos que interessam à religião e fizeram importantes descobertas também no campo da filosofia moral e da retórica, no entanto, buscando conhecer o Sumo Bem, os filósofos e sua época consumiram seu engenho - In Summo Bono quaerendo plerique Philosophorum \& aetatem \& ingenium triverunt - sem obter o conhecimento do que era verdadeiramente mais alto e útil que tudo e que Cristo reservou para sua própria época - sed id, quod erat vere summum \& praestantissimum, suae Christus aetati servavit - pois, sobretudo, não há nada melhor e mais útil que o homem possa alcançar com as suas próprias forças, em segundo lugar depois do conhecimento do Sumo Bem, que a suma erudição - (...) quod ad Summum Bonum proxime accederet, summam videlicet eruditione. Quid enim secundum virtutem potest homini praaestabilius contigere scientia?.

\footnotetext{
${ }^{272}$ Rico, Francisco, op. cit., p. 6. Este comentador nos apresenta a propósito um trecho do prólogo das Elegantiae de Valla: “Os Pais da Igreja, os grandes mestres do pensamento cristão, por exemplo, valorizaram sempre com o ouro de sua eloqüência as gemas da linguagem divina, e somente quem será capaz de compreender aquela eloqüencia compreenderá também a palavra de Deus. E certamente, só os escritores eloquentes são colunas da Igreja” - Et certe soli eloquentes columnae Ecclesiae sunt”

${ }^{273}$ Desiderii Erasmi, LB, X, op. cit., 1710 D. No subtítulo anterior, "É absurdo criticar algo apenas porque foi descoberto pelos pagãos” - Absvrde Reprehendi Quipiam Non ob Alivd Nisi Qvod ab Ethnicis Inventvm Erasmo já havia mostrado a quantidade de descobertas pagãs que são utilizadas diariamente pelos pagãos sem qualquer escândalo ou mínimo escrúpulo religioso.
} 
Seguem os argumentos morais, que não eram vistos como menos eficientes ou menos recomendáveis ${ }^{274}$, apontando que a sacrificante descoberta e constituição da erudição pelos pagãos não devem ser desperdiçadas como objeto de desprezo - (...) quantus sudor Antiquis fuit? Quorsum tandem haec omnia? Num ut exorti contemneremus? - pois se os pagãos não houvessem plantado, os cristãos não teriam nada para colher - Quod nisi illi litterarum segetem sevissen, nobis fortassis nihil esset quod meteremus - pois às disciplinas que os pagãos descobriram com as próprias forças secundum virtutem - os cristãos não foram capazes de acrescentar nada - quid enim ipsis reperissemus, qui illorum inventis non modo nihil unquam adjecimus (...) - pois os cristãos são ingratos e invejosos ao recusar o que foi magnificamente constituído, é utilíssimo para o futuro e lhes é oferecido graciosamente - Quo turpius ingrati sumus, imo invidi, qui res summo usui futuras, ne gratias quidem oblatas accipere velimus, cum istis magno constiterint - pois enfim recusamos presentes belíssimos e ao invés de agradecer, como deveríamos, atiramos os piores insultos contra seu autor que afinal é o próprio Cristo - nec munus modo pulcherrimum recusamus, verum etiam auctorem muneris, pro gratia quam debebamus, summa contumelia afficimus.

Ainda se pode discernir argumentos simplesmente pragmáticos no estímulo ao aproveitamento das disciplinas já descobertas pelos pagãos porque nada é mais conveniente e fácil que receber e aprender as disciplinas cuja perfeição já foi arrancada às unhas, ao invés de descobri-las por esforço próprio - Non paulo enim proclivius est rem jam ad unguem expolitam perdiscere, quam invenire - e porque a Divina Providência quis conceder aos cristãos tempo livre para outros fins, os poupando da maior parte do trabalho - Deus Christianorum (...) otio consultum voluit, ut qui essemus aliunde occupandi, bonam laboris partem adimeret. Por último ainda é possível notar uma crítica, por certo dissolvida

\footnotetext{
${ }^{274}$ Cícero, op. cit., pp. 63 a 67. Expondo no De Inventione sobre as partes que compõem o discurso, o orador trata da confirmação - confirmatio - que traz a força da conviç̧ão - fidem - e se apóia sobre os atributos da pessoa ou da coisa. Neste último caso, que é aquele das disciplinas, a argumentação a seu favor pode ser necessária ou verossímil - probabile. Ao empregar os argumentos morais, Erasmo faria uso da argumentação verossímil que, apesar de não ter a aparência de uma conclusão necessária repousa sobre um raciocínio que, considerado em si mesmo, é necessário admitir - verum ipsa argumentatio ex necessaria ratione consistat. Entre estes está o apelo às idéias recebidas - judicatum - que se apóiam sobre a aprovação, a autoridade ou o juízo de uma ou várias pessoas e que ainda podem ser religiosas, comuns e confirmadas. As morais estariam enfim entre as comuns - commune - conformes ao sentimento e à prática comuns - quod omnes vulgo probarunt et secuti sunt (...),
} 
pelo uso da primeira pessoa do plural, aos próprios cristãos em relação às disciplinas antigas pois, além destes não lhes acrescentarem nada, ainda destroem muitas e desorganizam o inteiro corpus do saber - non modo nihil unquam adjecimus, verum detrivimus permulta, perturbavimus omnia.

O critério de hierarquização dos períodos históricos é, portanto, o conhecimento do Sumum Bonum pertencente apenas aos cristãos, o que lhes dá incomparável vantagem; mas é preciso lembrar que da sumam eruditionem dos gentios, entre as disciplinas descobertas, fazem parte aquelas, seja a filosofia moral ou retórica, que indagam e respondem corretamente a muitos níveis de questões anteriores e próximas ao Sumum Bonum - ressalte-se, apenas inferiores ao conhecimento do Sumum Bonum unicamente por meio da razão natural igual para todos os homens.

Parece que pertence à estratégia de Erasmo a defesa cuidadosa destas duas disciplinas imergindo-as em meio às outras, entre elas a excelência nas letras e na eloquência - litterarum dicendique laudibus - na investigação das causas secretas da natureza - rerum latentes causas rimari curae fuit - na observação dos astros - coelestium ignium vagos recursus observarunt - na diferenciação dos argumentos no estudo da lógica e na arte da sua elaboração e exposição pela retórica - hic differendi, ille dicendi rationem invenit - na descrição dos costumes estrangeiros pela geografia e na memória dos grandes feitos pela história - mortalium mores doctissime depinxerunt, quibusdam rerum gestarum memoriam - no empenho e aplicação às leis e à filosofia - jam vero in legibus, in philosophia, quantus sudor $?^{275}$ - pois as descobertas - inventiones- da filosofia moral ou retórica, são possivelmente aquelas que mais ameaça representam para uma religião enrijecida por mais de um milênio pelo estabelecimento e acumulação de dogmas, valores, preceitos morais e devocionais e, portanto, para a conciliação das disciplinas antigas ao cristianismo. O alcance potencial destas duas disciplinas sobre o território tradicional da religião acaba por ser deixado claro em Hyperaspistes, obra escrita quatro anos depois:

\footnotetext{
${ }^{275}$ Todos os excertos latinos apresentados nos últimos quatro parágrafos foram extraídos de Desiderii Erasmi, LB, X, 1712 e 1713.
} 
“O que a Lei era para os Judeus, intelectualmente pouco refinados, a força da natureza e das coisas criadas o eram para os Gregos de espírito vivaz e nada nos impede de chamar a isto de uma Graça, pois Paulo diz: "Deus lhes revelou”. Os Judeus, grosseiros como eram, buscavam signos, os Gregos a sabedoria. (...) Se os Gregos, pelas suas leis puniam as mesmas coisas que os Judeus, segue-se que, unicamente pelas forças da natureza, eles viam na maior parte dos casos o que é justo e aquilo que não é justo”276

Tanto quanto nosso talento permite sermos tão claros quanto comporta a natureza do próprio assunto ${ }^{277}$, parece que Erasmo, ao buscar a assimilação das letras antigas pelo cristianismo, patrocina a recepção das descobertas da filosofia moral no bojo da retórica antiga pela religião cristã como quem faz entrar de novo o cavalo aqueu em Tróia; mas também, no sentido contrário mostra como se dispersam confusamente em diferentes facções inimigas, devotadas cegamente às idéias de seus próprios fundadores, aqueles que se uniram inicialmente em torno da pergunta socrática pelo maior bem alcançável pelo Homem.

De fato, a Summa eruditione das disciplinas dos gentios e as invenções que, entre outras, fizeram no campo da filosofia moral e da retórica com o uso da razão natural, secundum virtutem, se aceitas como presentes belíssimos - munus modo pulcherrimum - e utilizadas e não desprezadas pelos cristãos como sugerido - vt nos uteremvr, non vt contemneremvs - levarão primeiramente à critica interna, dentro da própria cristandade, da religiosidade popular ignorante e supersticiosa, do politeísmo subjacente ao culto dos santos, da crença de que se é ex opera operato ao invés de que se é ex opere operantis presente no culto de objetos e ritos sagrados, etc., mas em um segundo momento levarão também ao alerta sobre a multiplicação dos dogmas e das crenças secundárias. Esta última crítica já é encontrada no seguinte trecho de uma carta de Erasmo a J. Carondolet :

"Antigamente a fé residia mais na vida que em enunciados de artigos de fé. Em breve a necessidade levou à redação desses artigos, mas em pequeno número e

\footnotetext{
${ }^{276}$ Jacopin, Paul, Lagrée, Jacqueline; op. cit. p. 62.

277 Cícero, op. cit., p. 68: “(...) ut facultas tulit, (...) nec minus dilucide, quam rei natura ferebat (...)” .
} 
segundo a simplicidade apostólica. Em seguida a audácia dos heréticos conduziu a um exame mais exato dos livros divinos e a dura teimosia levou à definição dos artigos de fé por uma autoridade sinodal. Finalmente a fé começou a ser encontrada mais nos escritos que nos corações ao ponto em que havia quase a mesma quantidade de crenças que de homens. Os artigos aumentaram e a pureza do coração diminuiu; a discussão se inflamou e a caridade esfriou. A doutrina do Cristo que anteriormente ignorava a disputa verbal começou a depender da proteção da filosofia: esta foi a primeira fase do declínio da Igreja. As riquezas aumentaram e a violência despontou" ${ }^{\text {278 }}$.

Esta crítica aos próprios cristãos graças à introdução e uso das disciplinas aperfeiçoadas pelos gentios - disciplinas ab ethnics expolitas - foi corrosiva contra o que há de grosseiro na religião cristã, mas logo evolui para a subordinação sistemática dos próprios dogmas e sacramentos à paz e à caridade buscando uma religiosidade em espírito, reduzida a um pequeno número de princípios, baseada na interpretação alegórica da bíblia, não literal, fundada na simplicidade da vida evangélica, que fale ao coração e transforme a vida, que recupere as regras de uma moral universal associada à noções de justiça, caridade, piedade, verdade ${ }^{279}$. Esta crítica é exercida publicamente e conduzida de maneira, diríamos socrática, em aberto debate retórico que Erasmo sustenta explicitamente nos seus diálogos, cartas e comentários de adágios e mais implicitamente na tradução e exegese dos evangelhos e dos Padres da Igreja. Se esta, como diríamos hoje, redução racionalista da religião ao essencial está na base do movimento ulterior da religião natural ${ }^{280}$, esconde um profundo pelagianismo ${ }^{281}$ quanto ao seu encaminhamento rumo à integração entre natureza e graça ${ }^{282}$, preanuncia sob o nome de ‘Cristo’ o que deverá esperar o século XVIII para ser

\footnotetext{
${ }^{278}$ Jacopin, Paul, Lagrée, Jacqueline; op. cit., p. 73. Os comentadores citam a carta número 1334 da Opus epistolarum Desiderii Erasmi Roterodami da edição P.S. Allen traduzida para o francês por A. Gerlo.

${ }^{279}$ Idem, pp. 66 a 74.

${ }^{280}$ Idem, p. 74.

${ }^{281}$ D’Ascia, Luca; em op. cit., p. 61: “Os Antibárbaros, bem mais que outras obras erasmianas, atestam o profundo pelagianismo que anima o humanista de Rotterdam, não tanto no sentido técnico do debate sobre a justificação (ao qual Erasmo se verá arrastado contrariamente a sua vontade entre 1524-26, com o seu De Libero Arbitrio e seu Hyperaspistes) mas naquele mais geral de uma integração entre natureza e graça, para além de uma rígida delimitação hierárquica de esferas, mas sobretudo, em evidente antítese ao antinomismo reformado"

282 Idem, p. 61.
} 
chamado de 'Razão' por Voltaire ${ }^{283}$ ou é um processo intrinsecamente irreligioso no sentido de que a razão crítica afinal não pode ser jamais convencida por uma Revelação, o que Lutero teria bem percebido, deixemos humildemente a questão em silêncio, pois conscientes da dificuldade - periculum intelligentes ${ }^{284}$.

No sentido contrário, podemos entender que Erasmo também aplica à própria história da filosofia moral a mesma redução racionalista ao essencial diante do espetáculo das divisões entre as diferentes escolas incapazes de abandonarem também suas crenças secundárias e imagens particulares para se colocarem em acordo e colaborarem para a melhor compreensão dos mesmos problemas fundamentais de um homem que tem urgência em agir com as melhores respostas possíveis e não em dilacerar-se em questões menores sopradas pela vaidade e teimosia que não saberiam se esconder de quem era leitor e tradutor de Luciano de Samosácia e conhecedor privilegiado dos componentes extrafilosóficos das disputas filosóficas como lemos neste trecho de seu Paraclesis :

"Platônicos, pitagóricos, acadêmicos, estóicos, cínicos, peripatéticos, Epicuristas conhecem a fundo cada um os dogmas de sua seita, eles os conhecem par coeur, se batem por eles e estão dispostos a morrer antes que abandonar a defesa de seus fundadores" 285 .

\footnotetext{
${ }^{283}$ Rico, Francisco, op. cit., p. 134. "Em longo prazo, parece possível encontrar a religiosidade de Erasmo em muitas páginas escritas dois séculos mais tarde; não nos escapa que as constantes éticas por ele perseguidas como terreno de encontro entre todos os homens se conjugavam com aquele do espírito cristão que o século das luzes acreditavam poder extinguir afirmando precisamente que 'a moral não deve se fundar na superstição, nem em cerimônias [...], a moral é a mesma entre os homens que fazem uso de sua razão' (Voltaire, Dictionnaire Philosophique, s. v. <Morale>): o laicisismo estratégico, instrumental, dos humanistas se torna valor autônomo entre os iluministas, a Razão tomava o lugar de Cristo”.

${ }^{284}$ Desiderii Erasmi, LB, X, op. cit., 1703 F. Na passagem - “(...) mas razoável e (como disse Fábio) consciente do perigo (...)" - sed cordati, \& (ut inquit Fabius) periculum intelligentis - Erasmo cita Marco Fabio Quintiliano ao descrever a atitude circunspecta de Batt antes de iniciar o exórdio de seu discurso pois o romano nas suas Institutiones buscando definir a justa medida de autoconfiança exigida do orador, e descrevendo uma experiência pessoal nos participa: “(...) Neque ego rursum nolo eum, qui sit dicturus, et sollicitum surgere et colore mutari et periculum intelligere (...)”. Extraido de nota de Luca D'Ascia em Erasmo da Rotterdam; Antibarbari, p. 112 .

${ }_{285}$ Jacopin, Paul, Lagrée, Jacqueline; op. cit., p. 75. Estes comentadores trazem o seguinte trecho de Paraclesis de Erasmo: "Platoniciens, Pythagoriciens, Académiciens, Stoïciens, Cyniques, Péripatéticiens, Épicuriens connaissent chacun à fond les dogmes de leur secte, ils les savent par coeur, ils se battent pour eux et sont disposés à mourir plutôt que de déserter la défense de leur fondateur".
} 
Mas esta crítica à polifonia filosófica talvez se deva, sobretudo, ao fato de Erasmo ter sido tocado pelo ceticismo acadêmico, que Cícero trouxera de Atenas para Roma, e pelo conseqüente ecletismo filosófico que este desenvolvera, senão a uma proximidade com a antiga retórica isocrática e sua prioridade para a paz e a concórdia política $^{286}$. Ao menos sobre sua simpatia pelo academismo estamos seguros, pois nos Antibárbaros, no subtítulo “A ignorância é a mãe da soberba e a erudição, ao contrário, da modéstia” - Ignorantiam esse svperbia matrem, ervditionem contra modestiam parere depois de refutar de imediato a acusação de que a literatura torna os homens presunçosos fastidiosos - lembrando que são as letras que dão forma ao espírito, moderam os afetos, domam a violência dos impulsos e suavizam o caráter trazendo o homem primitivo e selvagem para a civilização - agrestes homines ad humaniorem vitam (...) adduxit - e que a decorrência de certa suscetibilidade que irrita os ignorantes - ab optimis pessima discernentis - é antes prova de bom senso e capacidade seletiva. Erasmo apresenta o adágio grego traduzido por Jerônimo “A falta de preparação torna presunçoso e ao contrário, o saber é sempre acompanhado da preocupação de não errar” - Imperitiam adducere confidentiam, scientiae vero timorem esse comitem - e explica que a presunção acontece apenas porque os que se consideram eruditos - consummate doctos - atraem o odio dos ignorantes agindo com soberba, pois nem mesmo compreedem o que verdadeiramente sabem ou não sabem - non quid sciant aut nesciant satis cognitum habeant.

Erasmo se alinha ao dito atribuído a Sócrates “A ignorância pior é aquela de quem crê saber aquilo que ignora" - Recte enim Socrates dixit, nullam inscitiam esse majorem, quam qua quis se credit scire quod nescit” aceitando que na fase inicial dos estudos os conhecimentos superficiais levem a certa arrogância intelectual - juvenum more qui quo minus habent prudentiae, plus habent animi - desde que a natureza agindo assim, através de uma presunção infundada, talvez nos induza a enfrentar com mais determinação

\footnotetext{
${ }^{286}$ Margolin, Jean-Claude, in Coletânea R. Laffont, op. cit., p. IX. O professor Margolin, também no seu prefácio Érasme notre Contemporain ressalta o frequente matiz cético da posição erasmiana que se torna mais visível na diatribe sobre o Livre Arbítrio: «Mesmo no debate metafísico sobre a natureza e na querela teológica com Lutero a respeito do livre arbítrio, ele não abandona jamais o posto de observação humano, afirmando mais uma vez sua vontade de se manter à meia distancia de duas afirmações absolutas: Deus é tudo, o homem não é nada; e ao contrário: a liberdade do homem pode tudo. Esta 'via média' lhe valeu hostilidades ferozes nos dois campos, no momento em que os luteranos e católicos de espírito escolástico se preparavam para duros confrontos »
} 
as dificuldades do estudo - ad summos labores capessendos provocemur - mas em idade madura vê como necessária e incontornável a autocrítica celebrizada por palavras também atribuídas a Sócrates “Apenas sei que nada sei” - Hoc unum scio, quod nihil scio - que são origem ou prenúncio do ceticismo que a futura Academia de Platão abraçaráa ${ }^{287}$ e que mais tarde Cícero, que foi modelo para Erasmo e toda coorte - cohortis $^{288}$ - de humanistas, frequentará.

De fato, sua simpatia pelo ceticismo acadêmico é explícita quando afirma, sempre através do personagem Batt, que seria melhor que os bárbaros imitassem a modéstia dos acadêmicos - Satius erat Academicorum verecundiam imitari - que mesmo sendo muito superiores afirmavam no entanto nada saberem - nihil tamem scire professi - e preferiam discutir sobre tudo com a precaução de não afirmarem pretenciosamente nada com certeza - omnibus de rebus pudenter disputare, quam confidenter affirmare maluerunt - e chega a reconhecer que nem todos apreciam esta escola - Nec me fugit, esse que hoc Philosophorum genus parum probent - mas que, no entanto, esta lhe parece a melhor de todas - mihi vel omnibus anteferendum videtur. Associando novamente o ceticismo a Sócrates, Erasmo lembra que este, mesmo sendo modelo de erudição e eloquência Socratis doctum pariter ac facundum ingenium - julgado por Apolo como o único homem verdadeiramente sábio de toda a Grécia enquanto os outros pensavam saber o que ignoravam - quod cum alii sibi ea viderentur scire, quae nescirent - era tão modesto que, mesmo velho, estava sempre pronto a receber lições de todos e não achou vergonhoso receber aulas de retórica de uma mulher chamada Aspásia - Non sibi turpe duxit Rhetoricen, a foemina Aspasia doceri - ele que, como os diálogos de Platão indicam, demonstrou tanto empenho e rigor de análise - apparet studiosi quidem \& acuti - e sempre empregou um discurso mais questionador que dogmático - sed inquirentis potius, quam praecipientis oratio. $^{289}$

\footnotetext{
${ }^{287}$ Kristeller, P. O, op. cit., p. 75: “Os sucessores imediatos de Platão na Academia modificaram sua doutrina tal como a conhecemos, ligeiramente menos que outro aluno, Aristóteles, e no transcurso do século III a. c., esta Academia adotou um ceticismo mais ou menos radical, ao que se ateve por mais de duzentos anos”.

${ }^{288}$ A décima parte de uma legião romana.

${ }^{289}$ Desiderii Erasmi, LB, X, op. cit., 1717.
} 
Neste mesmo subtítulo, Erasmo deixa sutilmente de se dirigir aos usuais bárbaros, que escondem a ignorância e a preguiça para o estudo sob o hábito religioso, e passa a repreender os seus contemporâneos auto-intitulados filósofos e lança a enigmática admoestação: “Quem dera os 'filosofóides’ de nossa época - Et ô utinam nostri temporis Philosophastri - que nos sufocam com sua soberba, quisessem imitar a digna contenção deste 'pai' da filosofia e não a brilhante superficialidade de um “Górgias” - hujus omnis Philosophiae parentis verecundiam, quam Gorgia promptam garrulitatem mallent imitariestes que não entendem o sentido nem mesmo do que dizem - ne suam quidem ipsorum vocem intelligant - e que com a maior confiança ajuízam sobre tudo, aprovam, condenam, ordenam e prescrevem - magna fiducia quavis de re pronuntiant, probant, damnant, praecipiunt, praescribunt”. É uma clara crítica cética aos sofistas de seu tempo, mas também, parece, aos inadvertidos continuadores daquela polifonia filosófica que separou os discípulos de Sócrates, que abandonaram a sincera e rigorosa busca da verdade sobre os assuntos do Homem, e que autenticamente merece o nome de filosofia, por um apego obsessivo ou interesseiro a um autor ou escola.

Também é uma crítica cética aos teólogos multiplicadores de doutrina que obscurecem a verdade evangélica, pois Erasmo, ainda neste subtítulo, observa com acidez a maneira pretensiosa com que estes 'anti-acadêmicos' - Antacademici - inventam títulos esplêndidos para decorar obras banais - quam splendidis titulis suas nugas adornent tratam estas com o afeto que macacos dedicam aos seus filhotes - quam delicate simii isti suos catulos adament - sonham ter concebido 'pequenas gemas', outros 'pérolas', 'uma pequena flôr', 'uma pequena rosa', 'um espelho' - quod somniavit Gemmulam, alius Margaritam (...) Floretum (...) Rosetum (...) speculum (...) - além de 'sumas' e 'sumas das sumas' como se dispensassem as fontes - sunt qui summas \& summarum summas appellent, quasi lectori non fit alius scriptor requirendus - escolhem com presunção extravagante pseudônimos pomposos para sugerirem algo de excelso e sobre-humano - ut ipsi praeclarum aliquid ac supra hominem profiteri videantur - citam, se chegam a fazê-lo, grandes escritores da Antiguidade cristã como Basílio, Orígenes e Crisóstomo, com a afetação de juízes severos - aut non citant aut contemtim citant, velut censores - se tratam por títulos famosos tais como ‘Santo Doutor’, ‘Doutor Irrefragável’, Doutor Sutilíssimo’ e 
'Doutor Seráfico' como se mencionassem algo de mais sublime que o próprio Evangelho crepant illos suos Doctores santos, Doctores irrefragabiles, Doctores sutilissimos, Doctores seraphicos, tum sibi videntur adferre cui cedere debeat etiam majestas Evangelica. Depois desta já corrosiva crítica dos que parecem ter nascido para deteriorarem o saber - ad contaminandas literas geniti videri possint - Erasmo eleva o tom e torna-se estarrecedor ao advertir que são destes livros que as bibliotecas transbordam, que os professores ditam, que os pregadores citam - ex his contexi conciones Ecclesiasticas; que são eles a fonte das máximas com as quais se governa o mundo - ex his colligi dogmata quibus gubernetur Orbis - e, ainda em um crescendo finali, revela que são elas enfim a norma da ortodoxia cristã - ex his nos censeri Christianos, aut secus.

Em resumo, a combinação nociva destes astros - coelestium ignium ${ }^{290}$, dogmatismo e eloqüente disputa - magna fiducia et garrulitatem - entre cristãos, entre pagãos e entre ambos é fonte de todos os males para Erasmo que desconfia dos especulativos que tratando inicialmente dos problemas humanos se fecham progressivamente em um vocabulário abstrato e vazio, reservado para um número pequeno de especialistas dependentes da autoridade pessoal de seus mestres, que se envolvem em questões que não concernem em nada sua vida própria e nem lhes torna melhores nem mais felizes ${ }^{291}$.

Ressalte-se que Erasmo refere-se à filosofia moral e à teologia - cujo tratamento aristotélico, vide averroísta, e dialético lhe repugna especialmente - onde condena as divergências infinitas e reside seu principal interesse intelectual; quanto às outras disciplinas, como humanista, continua entusiasta da geral restauração das disciplinas pagãs e do seu reflorescimento como aquele da medicina, do direito etc., em que é benéfica e notória a polifonia das hipóteses em conflito e a utilidade e a necessidade da sempre

\footnotetext{
${ }^{290}$ Desiderii Erasmi, LB, X, op. cit., 1712 F.

291 Jacopin, Paul, Lagrée, Jacqueline; op. cit., pp. 68 e 69. Neste parágrafo utilizo algumas sugestões destes comentadores mas não concordo que se aplique a todas as disciplinas a condenação erasmiana à polifonia filosófica; creio tratar-se de crítica - reprehensio - específica aos continuadores da disciplina fundada pelo problema socrático, i. e., a filosofia moral, pois a polifonia das análises na filosofia natural é profícua; vide próxima nota.
} 
louvada $\operatorname{ars~loquendi~}^{292}$. Se bem que, a partir da prioridade que atribui à filosofia moral e à teologia, considere avant la lettre que a aplicação exclusiva às outras disciplinas torne estes especialistas detentores de um falso saber - indocte docti - na medida em que aceitam das disciplinas apenas a sua e detestam as letras humanas ${ }^{293}$ sem as quais toda doutrina é cega humanitatis autem litteras, sine quibus caeca est omnis doctrina ${ }^{294}$. Também merece ressalva uma segunda nuance no apoio de Erasmo à restauração geral das disciplinas: conquanto se reconheça nos Antibárbaros uma ética do esforço em aprender e a valoração da inquietude intelectual - curiositas - contraposto à preguiça e à ignorância dos bárbaros acusados de serem defensores de uma 'santa ignorância’ que pensam exaltar a humildade cristã com a demonização do saber como fonte de heresia e de impiedade - o autor não defende nenhum método de descobertas, pois para ele ‘ciência’ é antes uma enciclopédia de conhecimentos acabados, a soma dos Studia Humanitatis, a soma das artes ou disciplinas que compõem a summam eruditione, e não um caminho para a sua produção como será pensada por Francis Bacon um século depois; e esta ciência somente pode ser obtida pela

\footnotetext{
${ }^{292}$ Rico, Francisco, op. cit., p. 136. A ars loquendi tem um sentido operativo na própria raiz das disciplinas incluindo aquelas que tratam da natureza, pois estas têm sua aplicação baseada não na prova da experiência científica moderna, mas no estudo, apresentação e sustentação verbal de proposições entre os estudiosos da mesma disciplina, o que as torna dependentes do latim com o qual ocorrem os debates e encontram-se escritas suas fontes ; e. g.: “Ermolao Barbaro estava convencido que Plínio não tivesse se enganado (...) na Naturalis historia (...). No mesmo 1492, Niccolò Leoniceno, professor de medicina na Universidade de Ferrara, sustentava ao invés que as inexatidões (...) eram tão graves, confundindo a nomenclatura de certas substâncias farmacológicas, por exemplo, 'polion' e ‘tripolion', (...). No entanto ambos tinham sua parte de razão: o filólogo deveria conceder nisso mais ao médico do que teria desejado e o médico da sua parte não pôde não revelar como as intervenções do filólogo foram bem sucedidas em restaurar passos por ele considerados radicalmente falsos".

293 Jacopin, Paul, Lagrée, Jacqueline; op. cit. p. 16. “As 'letras humanas' (litterae humanitatis) como as chamam os Antibárbaros, ou melhor, ainda as 'litterae humaniores' (as letras mais humanas no sentido em que elas tornam o homem mais humano, mais conforme a sua natureza de Homem) se opõem claramente ao saber da natureza em tanto que elas nos instruem sobre o que é o homem, sobre seu valor, as condições de desenvolvimento individual e coletivo (moral e politico)".

${ }^{294}$ Desiderii Erasmi, LB, X, op. cit., 1704 e 1705. Erasmo passa em revista os três tipos de bárbaros que deve enfrentar. Entre os puros ignorantes ou preguiçosos que se escondem sob o hábito de uma ordem e os que querem saber tudo e pretendem ser grandes poetas e oradores mas acabam por prejudicar a República das Letras, estão os escolásticos que amam outras disciplinas, isto é a sua - caetera quidem studia, hoc est, sua (...). Neste caso, Erasmo usa o plural caetera studia, de onde deduzo que se refere aos escolásticos de maneira abrangente, i. e., a todos alunos e ex-alunos, não só da teologia, mas das demais disciplinas cujo ensino já foi institucionalizado pelas universidades, da scuola, e. g., direito e medicina. Erasmo os acusa de se fecharem com exclusividade sobre suas próprias disciplinas e se considerarem doutos sem as humanitatis litterae, sem as quais nada resta - sine quibus nullae constant litterae - e de serem contrários ao uso de tudo que seja refinado e elegante que eles mesmos não aprenderam - Omnem politiem interdicunt, \& quicquid ipsi non didicerunt (...) porque não conhecem os textos melhores, aqueles dos poetas e oradores e se satisfazem com seu destino - ab optimis abstinuerint, nempe Poetiscis \& oratoriis, sua tanquam sorte contenti.
} 
assimilação onívora de autores e textos ${ }^{295}$, assimilação certamente critica e interpretativa, mas de conteúdos já criados e que já expressam uma perfeição. Por isso, não ao acaso, resume todos estes bens intelectuais, que incluem os textos morais e dos Padres da Igreja, sob o termo 'ciência' perguntando sobre o maior bem que o homem possa alcançar com suas próprias forças - Quid enim secundun virtutem potest homini praestabilius contigere scientia? ${ }^{296}$.

Esta consideração nos remete à chave da solução erasmiana para a oposição e destruição mútua entre as diferentes escolas de filosofia da moral ${ }^{297}$ e as divergentes correntes de pensamento teológico: para Erasmo não há, para estas duas disciplinas, diferença entre ciência e sabedoria, entre conhecimento descoberto - inventis pelo árduo trabalho da invenção apoiada e controlada pela razão, polido até chegar às unhas - ad unguem expolitam - e a intuição sábia, guardada pela tradição oral, imagética, recebida pelos poetas, pelos criadores das leis jamais esquecidas; entre o conhecimento de técnicas agrícolas, complexos cálculos astronômicos e o conselho ponderado colhido em antigas fontes; entre o debate filosófico que evolui até a descoberta da autonomia moral superior às circunstâncias e a disciplina tradicional que oferece um sentido seguro para a ação. Em ambas, ciência e sabedoria, Erasmo nota a igual manifestação da invenção humana, guiada pela sua razão natural, criadora de soluções e conveniências para a vida, que Cristo quis que fossem reunidas e aproveitadas pelo século de ouro em que nasceria Hic aureo illi seculo, quo nasci (...) ad hujus unius felicitatem decusque cumulandum quaecunque in rerum natura essent, referre placuit ${ }^{298}$. Mas, se a época em que a lei da natureza desempenhava para os gregos a mesma função que a Lei de Moisés para os hebreus - a ponto de punirem as mesmas faltas e distinguirem igualmente o que é justo do que é injusto - acabou quando a ciência se distanciou da sabedoria pela multiplicação das escolas filosóficas morais, fato logo reproduzido pela multiplicação das doutrinas

\footnotetext{
${ }^{295}$ D’Ascia, Luca; op. cit., pp. 54 e 55.

${ }^{296}$ Desiderii Erasmi, LB, X, op. cit., 1713 C.

${ }^{297}$ A época em que filosofia e sabedoria estão reunidas pela última vez, poderia ser entendida como o período da ação ateniense de Sócrates cuja morte foi seguida da dispersão de discípulos que fundadoram suas próprias escolas. Parece que Erasmo fala sobre a elaboração retórica, pela busca comum, respostas para as questões fundamentais do Homem, diferentemente da especialização dialética em disciplinas voltadas para a natureza ou para o Ser, i. e., para a física e a metafísica.

298 Idem, $1712 \mathrm{C}$.
} 
teológicas dentro da Igreja e, em ambas as disciplinas, tanto na filosofia moral quanto na teologia ocorreu a divisão incessante das opiniões sobre os problemas fundamentais do Homem, então, para Erasmo, a redução das divergências a um denominador comum essencial significa fazer estas disciplinas remontarem à época em que coincidiam como uma única sabedoria.

Assim, entendemos a sua peculiar valorização dos provérbios grecolatinos - Adagia - pois, descobre nestes as centelhas de uma filosofia arcaica - prisca philosophia - indistinguível de uma sabedoria antiga - vetusta sapientia - pedras preciosas prontas para o polimento de um ensaio culto sobre ética, agradável e acessível, um paradigma de concentração contra a dispersão dos especulativos, pois defende uma filosofia reduzida a um pequeno número de princípios que falem ao coração e transformem a vida; defende um ensinamento fácil de ser compreendido e dirigido a todos que, para isto, deve ser transmitido em uma linguagem simples, imagética, adaptada à inteligência dos pequeninos e fácil de memorizar ${ }^{299}$. Vejamos seu comentário sobre a dignidade dos provérbios no parágrafo V dos Prolegomena aos seus Adagia:

“Além disto, para que não se vá desmerecendo ou mesmo desprezando esta parte do saber, certamente bem modesta, tão acessível e quase infantil, eu gostaria de expor em algumas palavras o quanto a Antiguidade concedeu-lhes em dignidade apesar de sua simplicidade, a comodidade que neles se via para aqueles que deles se serviam bem intencionados e eu mostraria enfim que não é dado a qualquer neófito lhes utilizar corretamente” $^{300}$.

Erasmo prossegue citando Diógenes Laércio para lembrar que autores de primeira grandeza não consideraram os provérbios indignos de si e os reuniram com cuidado em muitas coleções, entre eles Aristóteles, Crísipo e Creonte e, citando outras fontes, explica que o desaparecimento destas coleções é que obriga a busca destes em autores menores; que um escritor quanto mais possui talento e conhecimento, mais utiliza provérbios em suas obras, incrustados como gemas em suas argumentações como no caso

299 Jacopin, Paul, Lagrée, Jacqueline; op. cit., pp. 67 e 70.

300 Idem, p. 114. 
de Platão, Aristóteles, Teofrasto, Plutarco; que os imperadores romanos não os julgaram indignos da majestade imperial e os utilizaram para emitir opinião sobre assuntos importantes; que mesmo o Cristo os julgou apropriados aos seus ensinamentos e à expressão de mistérios; que para aquele que é mais sensível à autoridade das coisas antigas, é na forma de provérbios que nos chegou o saber mais antigo e a filosofia primitiva; que os oráculos se manifestavam na forma de provérbios; que por vezes, como no caso do provérbio "Conheça-te a ti mesmo", se lhes atribuía tanto respeito a ponto de acreditar que possuíam uma origem não humana e os escreviam nas portas dos templos, colunas e mármores para serem perpetuados ${ }^{301}$; que são os provérbios mais encerrados em si mesmos e pequenos que possuem mais espírito; entre suas vantagens, estes contêm quatro essenciais: a filosofia, a arte de persuadir, a beleza e o prazer da palavra e a compreensão dos melhores escritores. Mudando a ordem de argumentos, Erasmo lembra que segundo Synésios, Aristóteles estima que os aforismos não são outra coisa que vestígios de uma filosofia antiga desaparecida nestes cataclismos que afetaram a história da humanidade e que foram conservados pela sua concisão e brevidade tanto quanto pelo seu sabor agridoce e charme, e que eles contêm traços da velha sabedoria que foi bem mais perspicaz na busca da verdade que, em seguida, o foram os filósofos; que segundo Plutarco no seu comentário Como ler os poetas, os provérbios dos antigos são parecidos com as religiões de mistérios que manifestam sob a forma de ritos quase ridículos em aparência, verdades essenciais e sobrenaturais; que algumas palavras breves exprimem tantas verdades veladas que mestres da filosofia precisariam muitos volumes para nos comunicar.

Pois bem, o passo lógico seguinte para o pensador será mostrar também que a superação das divergências doutrinais na disciplina teológica - assim como demonstrado quanto à disciplina filosófica - se dá igualmente pelo reconhecimento de que para a teologia também não há diferença entre o seu tipo de conhecimento, sua ciência e a sabedoria antiga guardada nos provérbios; entre conhecimento profano e sagrado, entre a sapiência antiga e a sapiência bíblica, que estes não pertencem à esferas epistemologicamente distintas; que o conhecimento profano não é uma exclusividade de filósofos e que o conhecimento sagrado não é uma exclusividade dos teólogos; que os

\footnotetext{
${ }^{301}$ Horácio, op. cit., p. 174. Ode VIII do Livro IV: “as inscrições gravadas sobre os mármores públicos” incisa notis marmorea publicis.
} 
conhecimentos dos filósofos, dos sábios e dos teólogos enfim são todos da mesma ordem, todos se fundam na mesma invenção e razão naturais humanas, pois espelham igualmente o que está na natureza das coisas - quaecunque in rerum natura essent. Como visto acima, pelo plano divino - Divino Consilio - as descobertas da época dos gregos serviram à época de ouro do nascimento do Cristo - Hic aureo illi seculo, quo nasci decreverat, voluit ut omnes \& anteactae \& sequuturae servirent aetates - então, se as descobertas que os gregos fizeram apenas com o uso da invenção e razão natural servem à época de Cristo é porque estas descobertas com uso da razão são completadas ou complementares à Revelação do Summum Bonum e portanto pertencem à mesma ordem, i. e., entre as mais certas descobertas da invenção e razão humanas e o Summum Bonum da Revelação pode haver uma imensa distancia, mas pertencem à mesma cadeia de razões. Esta interpretação é corroborada pela citação que Erasmo faz da frase de Agostinho: nem o mal seja visto como criado inutilmente - ne mala quidem otiose creata videantur - que faz supor que todo mal integra uma cadeia de razões que no momento é obscura, mas é a mesma que se desdobra até o Sumum Bonum ${ }^{302}$. Parece que a comparação visa a seguinte conclusão: se nem o mal feito pelo Homem deixa de servir às mesmas razões que se desdobram até o Sumo Bem, menos ainda delas se afastará o bem por ele feito, e. g. as bonnae litterae. Continuando os seus Prolegomena, Erasmo dá um exemplo desta continuidade entre sabedoria dos provérbios, descobertas feitas pelas disciplinas pagãs e os ensinamentos da teologia :

“Este aforismo de Hesíodo: (...) 'Mais vale a metade que o todo’, não diz tanto quanto todos os raciocínios de Platão no Górgias e nos seus escritos políticos: 'Mais vale sofrer uma injustiça que cometê-la'? Puderam os filósofos alguma vez nos propor uma lição mais redentora, mais próxima da religião cristã? Tão rico é o conteúdo deste pequeno provérbio 'Mais vale a metade que o todo'! Aquele que toma o todo, lesa o outro a quem nada deixa. Inversamente, aquele que se contenta com a metade parece ter sido lesado em parte; ora, mais vale ser lesado que lesar. (...) O que faz Platão em tantos volumes, senão defender a comunidade e aquilo que a funda, a amizade? Se os mortais pudessem se persuadir disto, a guerra desapareceria imediatamente; com a inveja, a fraude, toda a tropa de maus dos quais seríamos instantaneamente liberados. E que fez de diferente o chefe de

\footnotetext{
${ }^{302}$ Desiderii Erasmi, LB, X, op. cit., 1712.
} 
nossa religião, o Cristo? Seguramente, ele não fez outro que transmitir ao mundo o preceito único da caridade, ensinando que dela somente procede o conjunto da Lei e dos profetas. Ora, à que nos exorta a caridade senão que tudo seja comum a todos? De tal maneira que unidos ao Cristo pela amizade que o liga ao Pai, imitando tanto que possível esta comunhão perfeita (...) possamos, por iguais laços de amizade sermos unidos uns aos outros como os membros dependem de uma mesma cabeça, e ser como um só corpo, vivificados por um mesmo espírito, sofrendo as mesmas dores e dividindo as mesmas alegrias.(...) Enfim, como a totalidade da criação está em Deus, Deus está em todas as coisas, e a totalidade dos seres está como reconduzida à unidade. Veja você que oceano de filosofia e mesmo de teologia nos revelou este pequeno aforismo"303.

Esta corajosa unificação dos conhecimentos, que pode tanto ser vista como naturalização do conhecimento sagrado como também sacralização do conhecimento profano obtido pelo uso da invenção e razão natural humanas, propondo articulações que nem mesmo o humanismo italiano ousou fazer, deixa claro que os Studia Humanitatis, longe de serem apenas exigência para a obtenção de subsídios técnicos de base para servir às disciplinas, como o conhecimento de línguas para o estudo da teologia, ou um banal verniz literário para o ensino da moral evangélica, ou mesmo da eloqüência para a predicação, estão ligados organicamente com a teologia, a fé e a Revelação e proporcionam a ruptura do dualismo mundo da natureza, estudado por doutrinas más, pagãs, e ímpias doctrinam malam, Ethnicam, impiam - e mundo da graça, tratado e glosado não por estudos humanos, mas celestes - non humano studio, sed (...) coelitos $^{304}$; mundo profano ocupado e entregue às contradições do conhecimento empírico, e mundo religioso recebedor passivo de inspiração divina; mundo das obras e de exaustivo trabalho intelectual e mundo do arrebatamento místico; mundo secular, de pessoas ativas, entregues ao trabalho e em contato com a pecabilidade da vida cotidiana e mundo sacro dos homens de espírito contemplativo, ociosos, fruindo da beatitude do êxtase de sua vida em santidade; mundo de religiosidade laica do corpus mixtum de todos os batizados e mundo de religiosidade radical dos perfeitos retirados em monastérios. Como resultado, a santidade que o cristão deve

\footnotetext{
${ }^{303}$ Jacopin, Paul, Lagrée, Jacqueline; op. cit., pp. 118 a 120. Os comentadores extraem da Opera Omnia edição ASD II/ 1, p. 52.

${ }^{304}$ Desiderii Erasmi, LB, X, op. cit., 1714 C.
} 
almejar não é alcançada através de visões e milagres, difíceis de serem confirmados, mas através do árduo estudo em um mundo único em que todos os conhecimentos pertencem à mesma ordem e pelos quais todos podem realizar a ascese ${ }^{305}$.

Mas será necessário dar resposta àqueles que repetindo Paulo alegam que “a ciência infla, mas o amor edifica” - scientia inflat, caritas edificat ${ }^{306}$ - com a intenção de manter o dualismo acima, pressupondo que o conhecimento fundado na invenção e razão naturais - scientia - é voltado unicamente para este mundo e para a vaidade humana e ultrapassado por um conhecimento diferente fundado em ordem outra de razões superiores - a $\operatorname{Caritas}^{307}$. Para a refutação - reprehensio ${ }^{308}$ - deste uso da frase de Paulo é estabelecido nos Antibárbaros todo um subtítulo propriamente chamado "Como se deve interpretar a frase de São Paulo: 'O saber infla' ” - Illvd Pavli, scientia inflat, qvomodo accipiendvm - onde Erasmo primeiramente busca neutralizar seu impacto lembrando que a ignorância também infla - sed inflat \& inscitia - que o próprio Paulo valorizou a ciência afirmando em uma outra passagem da bíblia - alio in loco - que "a expressão é rude mas não a ciência que ela contém” - etsi imperitus sermone, non tamen scientia - e que este Apóstolo contava como sua vantagem o fato de haver estudado aos pés de Gamalieo - ad pedes Gamalielu - que o mesmo pedia livros aos seus interlocutores - libros sibi postulantem - ele que, entre os Apóstolos, era o maior conhecedor de todos os assuntos cum fuerit vunus inter Apostolos omnium rerum scientissimus - e sempre nos provocava a imitá-lo - saepius nos ad sui imitationem provocarit.

A seguir, Erasmo emprega como filólogo o método crítico para a correta compreensão da frase, convidando o leitor a comparar os antecedentes e as conseqüências desta com o seu meio original - priora \& consequentia cum mediis conferamus: foi perguntado a Paulo o que se deveria fazer com a carne dos animais sacrificados aos ídolos

\footnotetext{
${ }^{305}$ D’Ascia, Luca; op. cit., pp. 55 a 61.

${ }^{306}$ Desiderii Erasmi, LB, X, op. cit., 1718 E.

${ }^{307}$ D’Ascia, Luca; op. cit., p. 55. Segundo este comentador, os Antibárbaros são uma enérgica resposta às Confessiones de Agostinho e parecem refutar por antecipação uma tradição de sensibilidade religiosa agostiniana destinada a notável desenvolvimento no grand siècle: a contradição entre as razões do coração e o conhecimento do mundo.

308 Cícero, op. cit., p. 94. “A refutação é a parte onde as provas do adversário são arruinadas ou enfraquecidas” - Reprehensio est, per quam argumentando adversariorum confirmatio diluitur aut elevatur.
} 
pois alguns cristãos dela se abstinham por escrúpulo de consciência - infirmitate quadam conscientia - enquanto outros mais capazes - peritiores - se davam conta que aquela distinção não fazia sentido algum, pois tudo é puro para os puros e com razão a comiam sem fazer diferenciação. Mas o que sua religiosidade mais madura e espitualizada permitia fazer escandalizava e ofendia a religiosidade supersticiosa e frágil - superstitiosior \& infirmior - dos demais irmãos e os indispunham contra si. Então Paulo posicionou-se reconhecendo que não havia mal algum em comer aquelas carnes, mas que isto produzia efeitos quanto à caridade entre os irmãos - interesse tamem fraternae caritatis - desde que mais frágeis, com consciência diferente - aliena conscientia - se ofendem ao ver os irmãos recaírem supostamente na idolatria, e concluiu que é melhor que nos adaptemos à fragilidade dos irmãos - fraternae infirmitate obsecundare - do que negligenciá-los com base na nossa ciência pois afinal Deus prefere a caridade indulgente ao rigor soberbo e intransigente - gratiore esse superis morigeram caritatem, quam superbam \& contumacem scientiam.

Erasmo ajunta que é este respeito à fraqueza do irmão que é o "amor que edifica”; mas deixa implícito, no entanto, que é o conhecimento da real circunstância dos irmãos mais frágeis, o conhecimento mais amplo - scientia - que pode guiar nossa ação e capacidade de amar, pensamento apenas indicado com as seguintes perguntas: "O que é o amor sem ciência senão um navio sem timão?” e “Como se faz para amar aquilo que não se conhece?” - Quid autem est caritas spoliata scientia? nempe navis sine clavo. Quis unquam amavit quod nesciret? - em que há a clara referência a Agostinho ${ }^{309}$.

Mas Erasmo continua e passa ao ataque advertindo que seria mais justo que o ignorante desse ouvidos a quem tem a ciência - Aequius erat indoctiorem scienti concedere \& parere - do que este ser obrigado a descer ao nível de quem ignora - imperito concedit doctior - pois é o que precede em ciência que tem sua caridade elogiada por Paulo - Huius caritas laudatur, qui te scientia praecedit, non tua - desde que a ignorância, ao

\footnotetext{
${ }^{309}$ Agostinho, op. cit., p. 267. Agostinho pergunta: "Mas quem ama o que desconhece? - sed quis diligit quod ignorat? - Pode-se conhecer algo e não o amar. Pergunto, porém, se é possível amar algo que se ignora porque se isso for possível, ninguém é capaz de amar a Deus, antes de o conhecer” e diante da original e insolúvel questão que acaba por se propor, já se vê obrigado a invocar a fé: “(...) temos de o amar, apoiados pela fé.(...) Ama-se, portanto, o que se desconhece, mas se crê.”
} 
contrário, já teria apagado a caridade daqueles que tomaram a sério uma mera superstição e se indisporiam contra seus irmãos se estes não tivessem sido caridosos por sua vez - tua ignorantia jam caritatem exstinxerat, qui credebas esse aliquid, quod nihil erat - sendo certo que sem a sua ciência a tolice dos mais frágeis não receberiam qualquer concessão nisi huius scientia tua stultitiae ultro concessisset - e por isto, estes devem ser tolerados não elogiados - toleraris, non praeferris. $\mathrm{O}$ ataque ainda busca argumentos na história e alerta que a tolerância para com a ignorância dos mais fracos era uma necessidade específica do primeiro cristianismo, pois a superstição havia aprofundado suas raízes e a caridade cristã exigia a aceitação provisória do escrúpulo formalista de tantos irmãos e, até o estabelecimento da doutrina evangélica, toda concessão era necessária - ad confirmandam Evangelii doctrinam, omni obsequio erat opus; mas isto na esperança de que posteriormente veriam sozinhos a verdade - sed hac spe ut post resipisceret - afinal, pergunta Erasmo: “Deveremos sempre fazer concessão aos ignorantes?” - An vero semper imperitis concedendum? - A resposta é um taxativo "não" - Minime - pois a exortação de Paulo valia apenas para a época em que a intransigência violaria a caridade - in quibus neque nisi violata caritate obsisti potest. Podemos então concluir o que por pouco não é explicitado: passados os primeiros tempos do cristianismo, espera-se que todos sejam responsáveis pela superação da religiosidade supersticiosa e frágil com o auxílio da ciência.

Ainda para enfrentar os argumentos mais simples, o autor desce à arena e desafia: Quem é mais inflado? - inflatior - Tu bárbaro e ignorante - imperitus - que recusas a ouvir quem sabe ou este que possui mais ciência - doctior - e usa de indulgência para contigo? Por que somos tão auto-indulgentes a respeito da nossa própria ignorância? Cur nobis ignorantia placemus? - Por que afastamos dos Studia Humanitatis quem teria capacidade e entusiasmo para fazê-los? - ab optimis studis deterremus - Por que, ao invés, não dizemos: "Vá de velas cheias para as disciplinas humanas, mas navegues cautelosamente?” - sed caute naviges facito - e explica que Paulo não quer a extinção da ciência - non vult scientia esse nullam - apenas não a quer sozinha, sem a caridade e lembra que para Agostinho a ciência é de per se inútil, mas com a caridade se torna útil inutilis est scientia, cum caritate utilis - e que é absurdo que alguém possa recusar o que é bom apenas porque vê o melhor - non optima quaedam est scientia, si melior fit caritas? - 
afinal, novamente Paulo, tem a ciência entre os principais carismas - scientiam inter praecipua charismata ponit e jamais quis nos afastar desta; na verdade o seu exemplo nos convida a buscá-la - ad quam nos suo provocavit exemplo, e pretendeu tão somente mostrar, como um navegador prudente, os recifes e rochas, para que os evitemos - scopulos \& caute prudens navigator ostendit ne imprudentes in periculum incideremus.

Encerrando este subtítulo, Erasmo concede que se fôssemos obrigados a escolher entre ciência e caridade seria melhor renunciar à ciência que à caridade tolerabilius esse scientia, quam caritate privari - e que esta é uma via mais segura que a ciência que, apesar de necessária, envolve alguns perigos e porque pode ser prejudicial se afastar a caridade - scientia (...) quae possit esse pernitiosa, ita si caritati repugnet - e conclui a serie de argumentos conclamando os estudantes das nobres artes - egregias artes - a não descuidarem da moral - recte tibi curas - e a estudarem não menos para serem melhores - non minus melior esse - que para reunirem mais conhecimentos - quam doctior - pois, afinal a ciência é boa mas a caridade é melhor - bona est scientia, caritas melior mas se são reunidas, se atinge a perfeição - si commitem adjunxeris, rem absolutam conficies $^{310}$.

\footnotetext{
${ }^{310}$ Desiderii Erasmi, LB, X, op. cit., 1718 E e F, 1719 e 1720 A. Todas as últimas citações pertencem ao subtítulo "Como se deve interpretar a frase de São Paulo: 'o saber infla'. " - Illvd Pavli, scientia inflat, qvomodo accipiendvm, não necessariamente na ordem original.
} 


\section{CAPÍTULO IV}

\section{POR QUE PRECISAMOS DOS STUDIA HUMANITATIS}

Na parte final do Antibárbaros, sempre por meio de seu alter ego, o personagem “Batt”, Erasmo faz o recenseamento de todos os argumentos antibárbaros apresentados e verifica em resumo que a primeira parte do livro foi toda dedicada a enfrentar os bárbaros com o raciocínio ${ }^{311}$, que a segunda parte foi utilizada para desautorizá-los com a apresentação dos testemunhos bíblicos, patrísticos e dos doutores da Igreja $^{312}$, e que a última parte será o lugar do combate definitivo que irá expulsá-los de sua última fortaleza ${ }^{313}$ : o argumento bárbaro da existência de certas pessoas de reconhecida virtude que foram consideradas doutas sem precisar da erudição profana ou que desprezaram a virtude em prol do rigorismo moral - i. e., desprezaram, como talvez possamos dizer hoje, a permanente busca socrática do conhecimento do que é a virtude, das ações que conduzem à realização do Sumo Bem, em troca da estrita obediência a determinados preceitos morais assumidos sem reflexão crítica - pois, como pretendem estes bárbaros, a fé cristã não foi introduzida por sábios, estudiosos da lógica, poetas ou retores. Com efeito, os Apóstolos não foram escolhidos entre os membros da Academia platônica, entre os estóicos do Pórtico ou da escola peripatética, mas entre pessoas simples, rústicas, incultas, na maior parte pescadores. A isso acrescentam que Jesus chamou estas pessoas enquanto trabalhavam, e não lhes ensinou retórica ou dialética, mas limitou-se a lhes ditar preceitos morais $^{314}$.

Este argumento que invoca uma suposta rusticidade dos Apóstolos é muito importante, pois sub-repticiamente implica a tese da inspiração de um conhecimento divino de natureza diversa da erudição profana, tese aparentemente sustentada pelo dito do

\footnotetext{
${ }^{311}$ Propomos que esta primeira parte em Desiderii Erasmi, LB, X, op. cit., estende-se do início do livro em 1693 B até $1725 \mathrm{E}$.

${ }^{312}$ Para a segunda parte propomos o trecho entre 1725 F e 1734 F.

${ }^{313}$ Para a terceira parte propomos o trecho entre 1735 A e o final em 1744 F.

${ }^{314}$ Desiderii Erasmi, LB, X, op. cit., 1735 A.
} 
Evangelho $^{315}$ que proíbe a preocupação com o alimento e a roupa do amanhã e faz crer em uma assistência divina permanente o que incluiria a assistência intelectual, e. g., no pronunciamento de um discurso ou na concepção de um livro ou carta. Erasmo sabe que o tema da rusticidade dos Apóstolos reintroduz perigosamente o pensamento dicotômico que separa um saber profano, humano, secular, mundano de um saber divino, inspirado, celeste - solapando e invibializando a noção fundamental da unidade da verdade com uma imagem amplamente aceita - e que então deve agora apresentar argumentos invencíveis, ponto a ponto, contra os últimos focos de resistência teórica que se escondem sob esta imagem popular e que se opõem de maneira inconciliável ao pensamento humanista, todo engajado justamente na aproximação entre o homem e a Divindade ao reivindicar para ambos o compartilhamento em diferente proporção de uma mesma razão - como expresso na proposição grega do Homem como microcosmo do universo ${ }^{316}$ preservada pela interpretação bíblica agostiniana do Homem como imagem refletida e semelhante de Deus $^{317}$ e plenamente assumida pelos renascentistas ${ }^{318}$. Trata-se, portanto, como última exposição sistemática sobre o tema pelo autor ${ }^{319}$, de um definitivo esforço para esgotar os argumentos intelectuais ocasionalmente articulados e a resistência disforme, acrítica, conformista, às vezes mesmo supersticiosa dos inocentes vulneráveis à explicação

${ }^{315}$ Evangelium secundum Matthaeum 6, 25 et 26, Nova Vulgata - Bibliorum Sacrorum Editio, Città del Vaticano, Libreria Editrice Vaticana, Editio Typica Altera, 1998, p. 1462: “Assim vos digo: Não seja a vossa alma preocupada com aquilo que comeis, nem com o que vosso corpo veste. Não é a alma mais que o que come e o corpo que sua vestimenta? Olhai para as aves do céu, pois não semeiam nem temem, nem ajuntam em celeiro e vosso Pai celeste as alimenta. Não sedes vós muito mais para ele?” - Ideo dico vobis: Ne solliciti sitis animae vestrae quid manducetis, neque corpori vestro quid induamini. Nonne anima plus est quam esca, et corpus quam vestimentum? Respicite volatilia caeli, quoniam non serunt neque metunt neque congregant in horrea, et Pater vester caelestis pascit illa. Nonne vos magis pluris estis illis?

${ }^{316}$ Jaeger, Werner, op. cit., p. 156. "O Homem de Heráclito é uma parte do cosmos. Tal como as suas demais partes. Quando, porém, ganha consciência de que traz no seu próprio espírito a lei eterna da vida do todo, adquire a capacidade de participar da mais alta sabedoria, cujos decretos procedem da lei divina”; Carlo Colombero tratando do pensamento de Leon Ebreo, nos informa que para este "Assim é a verdade: que o Homem é a imagem de todo o universo: e por isso os gregos o chamam de 'microcosmos” (op. cit. p. 59).

${ }^{317}$ Agostinho, op. cit., pp. 461 e 532 respectivamente: “A trindade da sabedoria é a imagem de Deus” e "A alma reflete as processões divinas”.

${ }^{318}$ Colombero, Carlo, op. cit., pp. 14 e 15. "Homem e natureza se apresentavam como duas entidades dotadas cada uma de uma própria originalidade, mas não contrapostas e sim ligadas por uma relação de ação recíproca que, em última análise, redunda em vantagem para a dignidade humana. Tal modo de pensar encontra a sua expressão típica no conceito de 'microcosmos', o qual - com vários matizes e com maior ou menor insistência - reaparece constantemente nos escritos de um grande número de autores do século XIV e XV, a tal ponto de constituir um lugar comum”.

319 D’Ascia, Luca; op. cit., p. 47. Depois desta obra, Erasmo concentrar-se-á em outros temas mais especificamente teológicos e a defesa da metodologia humanistica será mantida apenas nas suas ocasionais apologias, assim, para o comentador: “Com a publicação do pequeno volume epônimo culmina brilhantemente, mas chega ao exaurimento, a inspiração ‘antibárbara’ do humanista de Rotterdam”. 
maravilhosa pelo milagre - apoiados nisto por autoridades com motivos inconfessáveis contra a idéia talvez mais poderosa e cara aos defensores dos studia humanitatis: a unidade da verdade.

Correndo o risco de arruinar um prato delicado tocando-o com o utensílio frio da análise acadêmica, devo propor que nesta parte final dos Antibárbaros, onde dezenas de argumentos são ingredientes que se combinam ora em contraste, ora em complementação, ora reintroduzidos com variações sutis evocando reminiscências e sugerindo associações difíceis de definir, há uma determinada ordem de idéias, há uma específica estratégia de convencimento ${ }^{320}$, há mesmo a possibilidade de uma nomenclatura e classificação, termos terríveis e ao gosto escolático que, no entanto, se não facilitarem futuras discussões, ao menos podem estimular a busca por melhores resultados.

Assim, como proposta de análise, localizo na parte final dos Antibárbaros 32 argumentos $^{321}$ e identifico antes de tudo quatro destes empregados para atacar já de imediato a justificativa bárbara, nem sempre sincera, de que a rusticidade dos Apóstolos é digna de imitação e, simultaneamente, fustigar a alegação implícita e acrítica, desavidada ou de má fé, de que há uma cisão entre o saber divino e o profano; a seguir, cinco argumentos que mostram que os Apóstolos não eram rudes, pois estudaram intensamente assim como os Padres da Igreja que os sucederam; depois outros cinco argumentos que mostram as vantagens da erudição profana para a religião e o fato de não serem

320 Érasme de Rotterdam, La Langue, op. cit., pp. 14 e 30. O rigor discreto que o autor emprega na organização deste seu longamente refletido Antibárbaros se torna visível e evidente quando comparado a outros escritos mais expontâneos e menos estruturados como o seu Lingua de 1525 que mereceu os seguintes e desconcertantes comentários do tradutor em recente edição: “O que faz Erasmo esquecer seu senso de medida, que é para ele uma marca essencial da filosofia cristã, e um dos princípios fundamentais de sua pedagogia? ", "Mas a escolha deste modelo reservado para a eloqüência fictícia para falar de um assunto que nós acabamos de nos certificar de sua urgência e necessidade pode parecer contraditório; ainda mais que, se deixando levar pela fantasia constitutiva do gênero, Erasmo faz com que a argumentação tome um caminho diferente daquele que parecia seguir: assim ele parece perder-se" e "A obra publicada se caracteriza, em efeito, por uma composição extremamente solta. O leitor se choca com certas descontinuidades acentuadas, freqüentemente por ausência de transições ou pelo arbitrário na disposição. ” além da transcrição da opinião de seus colegas comentaristas J. H. Waszink: “A Língua, como muitas polêmicas envolvendo a literatura grega no fim da Antiguidade, não tem estrutura clara; nós cremos então que todos os esforços para encontrar uma aqui uma tal estrutura (...) são inúteis" e Elaine Fantham: "Erasmo teria feito bem em abreviar ou ao menos condensar o argumento do Lingua e tornar visível a direção de seu pensamento através de títulos. Eu tomei a liberdade de inserir alguns destes para ajudar o leitor a avançar sem se distrair demais com as pequenas narrações”.

${ }^{321}$ Esta identificação de 32 argumentos é de minha autoria e responsabilidade. 
condenadas; ainda seis argumentos que fundamentam a responsabilidade do homem mesmo diante da hipótese de que o saber profano possa ser obtido por uma suposta inspiração divina e, finalmente, doze argumentos que refutam ex totum a noção geral de uma inspiração divina baseada na separação entre um saber humano e um saber divino.

Quatro argumentos no ataque aos bárbaros que alegam imitar uma suposta rusticidade dos Apóstolos e trazem em seu apoio a concepção de que há uma cisão entre saber divino e profano; primeiramente o argumento da hipocrisia: aponta a má fé, senão ignorância, de quem reivindica a imitação de uma alegada rusticidade dos Apóstolos, mas não imita sua inocência e virtude moral, pois mesmo admitindo que os Apóstolos eram rudes, este seria apenas um aspecto de suas personalidades e não há como explicar que os bárbaros imitem apenas esta hipotética rusticidade e, no mais vivendo uma vida indigna, critiquem os estudiosos em nome desta mesma rusticidade, afinal é inaceitável que Esopo dê preceitos de frugalidade, Sardanapalo escreva um tratado sobre a vida austera. Apenas seria suportável que os estudiosos fossem criticados pelos bárbaros se estes fossem virtuosos como os Apóstolos, mas ao invés, causa desgosto representar com o pensamento a vida corrupta de alguns deles que, mesmo havendo recebido a ordenação e vivido de um salário eclesiástico, já envelhecidos, ainda parecem disputar em luxúria com o próprio Sardanapalo em pessoa e atacam mesmo os professores laicos de letras humanas que se dedicam às coisas do mundo e devem conhecer as disciplinas pagãs por escolha profissional. Estes bárbaros atacam com processos jurídicos e acusações gravíssimas os professores que se satisfazem em ler os filósofos antigos, as histórias do mundo grego e latino, as obras dos poetas e dos oradores enquanto eles, que deveriam ler e meditar dia e noite a Lei do Senhor e a Sagrada Escritura, se afastam devota e escrupulosamente mesmo deste estudo temendo que, ao se acostumarem a tomar livros em suas mãos, venham a se encontrar sem querer em companhia de autores pagãos ${ }^{322}$.

Quem imita a suposta rusticidade dos Apóstolos não imita sua inocência e virtude moral, pois estes não caçavam, não se vestiam com ostentação, não mantinham um rebanho de concubinas, gastavam imensas riquezas, construíam com recursos da Igreja

${ }^{322}$ Erasmo da Rotterdam, Antibarbari, op. cit., pp. 206 e 207. 
palácios verdadeiramente reais onde por todo lugar se ouve o rumor da soldadesca a serviço dos prelados, em cujos grandes salões resplandecem utensílios de luxo, se preparam jantares faraônicos e banquetes sibaritas, se joga, dança e bebe muito vinho; são estes os imitadores que, depois de muito beber e já falando com dificuldade e rusticamente, pensam que assim imitam os supostos rudes discursos dos Apóstolos. São estes que querem que os professores das disciplinas profanas imitem o estilo de vida dos Apóstolos ${ }^{323}$.

Mas os bárbaros podem ainda alegar que mesmo que aceitemos que muitos homens santos cultivaram as disciplinas pagãs e que isto seja uma virtude - Demus sane complures pios viros litteratura profana cum laude usos - os fundadores, os chefes e primeiros líderes da nossa religião - nostrae Religionis et auctores, et duces, et principes foram homens rudes e ignorantes - rudes et nullis instructos litteris - então o que há de melhor a fazer é imitar os melhores - vero summae laudis et primae judico, primos ac Summos aemulari. Ora, não se trata aqui de impedir a imitação dos Apóstolos, ao contrário, deve-se imitá-los, mas no que tange à moral; quanto à erudição, siga-se de preferência o exemplo de Jerônimo - Apostolos imitari te veto? Imo jubeo, at ita ut moribus Apostolos exprimas, eruditione Hieronymum - pois atualmente todos se esforçam por imitar apenas a rusticidade dos Apóstolos e ninguém lhes imita a vida - nunc apostolicam ruditatem imitantur omnes, vitam nemo. Certamente devemos imitar os melhores, mas é errado escolher como modelo o aspecto menos valioso de uma grande personalidade - sed tu perperam facis, qui e primis et summis viris, id quod est extremum et infimum, tibi proponas. O bom imitador não deve estar atentíssimo apenas ao escolher bem seu modelo mas também ao selecionar os traços mais positivos ignorando certamente algumas características e criticando outras - verum in eo ipso quod optimum putaverit, excerpit, quaedam praeteribit, quaedam reprehendes. Pedro é o maior, mas também Jerônimo é o primeiro, aquele entre os Apóstolos, este entre os doutores da Igreja. Pedro era o maior no ardor da fé, e Jerônimo na doutrina: creia como Pedro e estude como Jerônimo - In Petro summus erat ardor fidei, in Hieronymo summa doctrina, alterius animum, alterius studia imitare $^{324}$.

\footnotetext{
${ }^{323}$ Idem, pp. 207 e 208.

${ }^{324}$ Desiderii Erasmi, LB, X, op. cit., 1739 C e D
} 
$\mathrm{O}$ ataque à santa rusticidade, mostrada neste argumento como simplicidade enganosa, é coroado com uma citação de Jerônimo: "Sempre admirei e venerei a santa simplicidade, não a rudez loquaz - non verbosa rusticitas sed Sancta simplicitas - Quem diz imitar o estilo dos Apóstolos, que comece a imitar-lhes a vida prius imitetur virtutes in vita illorum - A sua excepcional santidade desculpará a sequidão da expressão - loquendo simplicitatem excusabit - o milagre dos mortos que se levantam refutará os silogismos de Aristóteles e as obstrusas sutilezas de Crisipo - syllogismos Aristotelis, contortaque Chrysippi acumina resurgens mortuus confutabit - Mas é ridículo que um cristão viva debochadamente depois se gabe da sua rusticidade - de sola rusticitate se jactet - como se todos os bandidos e outros delinqüentes fossem grandes oradores e como se uma espada ensangüentada se escondesse atrás dos livros dos filósofos (...)”. Assim, contra o argumento da rusticidade, esta rusticidade arruinada - perditam rusticitatem - e falsa simplicidade - simplicitatem fraudulentam - deve-se mostrar que quem o utiliza quer, na verdade, justificar com má fé ou por ignorância a sua própria rudez e não imitá-los realmente ${ }^{325}$.

O argumento da redução ao absurdo do elogio à pura rusticidade: a rudez e a ignorância extrema não permitiriam a compreensão de qualquer oração, mesmo as diárias e mais simples e afinal, se os bárbaros desejam ter sua rusticidade reconhecida, eles têm do que se orgulhar pois estariam em vantagem se comparados aos próprios Apóstolos desde que são mais rudes que qualquer pescador; mas acontece ainda que a vantagem da ignorância é breve pois qualquer popular poderia se prevalecer do mesmo ${ }^{326}$. Erasmo já havia reduzido ao absurdo o argumento que alega a rusticidade dos Apóstolos em trecho anterior dos Antibárbaros no subtítulo "Os homens se tornam soberbos mais por causa da ignorância que pela erudição” - Homines ignorantia potius quam eruditione insolentiores fieri $^{327}$ - ao lembrar que alguns bárbaros são tão estupidamente devotos que chegam ao cúmulo de desprezar também a erudição chamada de “cristã”, i. e., eclesiástica, e ainda dizem "Tanto faz, se não somos teólogos. Se você conhece bem a Cristo, que importa

\footnotetext{
${ }^{325}$ Idem, 1737 C. Em Erasmo da Rotterdam - Antibarbari, p. 211, Lucca d'Ascia nos informa que este trecho de Jerônimo se encontra na sua Epistola LVII.

${ }^{326}$ Erasmo da Rotterdam, Antibarbari, op. cit., p. 207.

${ }^{327}$ Desiderii Erasmi, op. cit., 1713 F a 1714 A.
} 
ignorar o resto? - Quid enim, inquiunt, si non simus Theologi, si Christum bene scis, satis est, si caetera nescis - A vida eterna foi prometida não aos doutos, mas aos inocentes Non Doctis, sed innocentibus promissa est immortalitas - Irei para o inferno por haver interpretado de maneira rasa e superficial uma passagem de São Paulo? - Num idcirco damnabor, si divi Pauli scripta parum sublimiter intelligam ? - Por não haver compreendido uma palavra de São Jerônimo? - Quid si Hieronymianam dictionem non capiam? - Por não haver também lido nenhuma obra de Santo Ambrósio ou Santo Agostinho? - quid si Augustini et Ambrosis scripta ne legerim quidem? - Por não conseguir nem, ao menos, compreender o Evangelho? - quid si ne Evangelium quidem intellligam ? - Para Erasmo, quem se justifica assim é um tolo, pois se não consegue entender nem a si mesmo, pouco lhe importa se é um homem ou um camelo - stolide, imo quid si ne teipsum intelligas, quid si camelus sis, non homo ? - E se este tolo insiste teimosamente que até os mais estúpidos animais irão para o céu, não é apenas tremendamente obtuso mas também blasfemo - Confide, etiam pecora caelum obtinebunt. Hominum mehercule genus non modo stolidissimum, verum etiam impium.

Também no subtítulo "Quem odeia as letras que ignora, não é um devoto, mas um invejoso” - Invidum esse, haud religiosum, odisse litteras, quas nescias ${ }^{328}$. Erasmo já havia explorado o absurdo a que pode chegar esta posição: os bárbaros chegam a dizer que quem for capaz de desprezar as disciplinas pagãs inventadas para a ostentação de erudição - qui disciplinas istas Ethnicas, ad ostentationem et superbiam inventas - por amor da fé, terá um lugar de exceção no paraíso - singulare inter coelites praemium illos manere dicunt - Sustentam que os céus amam mais que qualquer coisa a devoção dos simples - quasi vero aut superos rusticitas nostra quicquam delectet - como se a rusticidade agradasse a divindade, mas nesse caso deveríamos dar a palma da vitória aos animais brutos - quod si est, cur non bruta in primis amplectimur? - como se a ignorância servisse para alguma coisa na vida - aut ad ullam vitae administratione utilis fit ignorantia - e não fosse uma prova de imbecilidade - ac non potius insulsissimum fit - mas antes, prova de loucura desprezar nos outros uma qualidade magnífica que não se possui e não se

${ }^{328}$ Idem, op. cit., $1707 \mathrm{E}$. 
espera conseguir - ac plane dementis, rem pulcherrimam quam nec habeas, nec habere speres, in aliis contemnere $e^{329}$.

O argumento da contradição: já no final de seu Antibárbaros, Erasmo ainda lembrará que aqueles que alegam imitar uma suposta rusticidade dos Apóstolos e insistem sobre a necessidade de humildade são conduzidos a paradoxos e inconsistências, pois não renunciam ao prestígio da erudição - ita simplicitatem praedicant, ut docti tamen haberi velint - reconhecem não haverem aprendido nada, mas continuam a querer parecer saber tudo - ita se nihil didicisse fatentur, ut nihil non sciant tamen ${ }^{330}$.

O argumento “Flandres”: Erasmo demonstra os equívocos práticos das vidas baseadas na divisão do conhecimento entre divino e humano; equívocos a que são levados os bárbaros, que não sendo capazes de teorizar, assumem sem crítica ou de má fé esta atitude dicotômica. O argumento é ilustrado por uma imagem cheia de colorido que mostra as conseqüências desta opção que só não pode ser tomada por insanidade por causa da evidenciação da ignorância do personagem descrito: Batt narra um episódio durante uma missão diplomática em Flandres em que se encontra em um jantar fora do comum, no qual, para amenizar o embaraço criado pela louvação que o personagem proprietário da casa e clérigo havia feito da hospitalidade que oferecia, recorre à lembrança agradável de mitos da literatura antiga, mas o proprietário reage chocado pedindo que à sua mesa não seja tocado jamais o nome daqueles pagãos para que o santo convívio não fosse profanado por aqueles nomes. Então Batt, para agradá-lo, passa a conversar com um jovem teólogo ao seu lado que também entendia de retórica e literatura, tratando apenas de autores eclesiásticos como Agostinho, Jerônimo, Lattanzio Firmiano, Ambrósio, Bernardo, Beda e Gregório Magno, mas ambos os citam comparando suas obras em um verdadeiro exercício de crítica literária apreciando o tipo de expressividade, o uso das figuras e ornamentos retóricos, sua pessoalidade, seu estilo, fluência, energia, clareza, erudição, brilho, concisão, artifícios, colorido, ritmo e musicalidade, conteúdo etc., ora, esta crítica ressalta o que há de humano nestes escritos tomados por sagrados, evidencia os artifícios que o escritor individualmente emprega, mostra o texto eclesiástico como conseqüência da série de opções feitas

\footnotetext{
${ }^{329}$ Idem, op. cit., $1708 \mathrm{E}$.

${ }^{330}$ Idem, op. cit., 1744 B.
} 
calculadamente pelos autores cristãos para a expressão escrita de uma doutrina, e então trata de maneira natural o que é reflexa e acríticamente, tomado pelo clérigo anfitrião por sagrado e sobre-humano.

O proprietário não compreende o que está em jogo e as razões para o tratamento dos textos religiosos como outros textos criados pelo engenho humano; se apega tão só - sempre a partir do ponto de vista dicotômico - ao entendimento simplista de que a valorização do humano implica em rebaixamento, atentado ao sagrado e irreverência, e acusa Batt e o jovem teólogo de quererem saber demais e colocarem problemas inoportunos com discursos frívolos e inúteis. Diante desta intervenção agressiva e pública Batt decide mostrar também em público - diplomaticamente, bem certo, a título de remédio pois para males extremos se deve usar remédios extremos - os equívocos em que incorrem aqueles que absolutizam facilmente uma noção de saber como sagrado, divino, inspirado mas não o compreendem para assumi-lo em suas vidas e relativizam e desprezam justamente o saber humano que é compreensível e poderia educá-los gradativamente e mudar suas vidas: Batt dirige então a conversação para a discussão de tipos de vinho, assunto em que o proprietário tem uma competência indiscutível; esta iniciativa é bem recebida por este que, percebendo a gravidade do tema, passa a discorrer largamente a propósito, com profundidade e precisão sobre o tema para uma platéia estupefata.

Ocorre que também as citações de Plínio avançadas por Batt são recusadas em favor da confiança total na experiência direta do paladar tomado por absoluto, analogamente às revelações do saber divino, como fonte segura da verdade, que desconfia de qualquer ensinamento humano e ingenuamente acredita na percepção direta da realidade em si dos objetos dos sentidos depreciando o papel das relações das percepções com a rede de conhecimentos humanos que chamamos hoje de "cultura” e cuja importância para a percepção só é compreensível através da crítica do entendimento humano e sua possibilidade de conhecer. O proprietário continua a se expor e se estende também sobre a preparação de pratos à base de caça e se revela superior aos mais famosos cozinheiros da antiguidade tais como Casio, Filosseno e Apício: em conclusão é esta a imitação da rusticidade dos Apóstolos, é esta a ciência eclesiástica rigorosa que se acrescenta a um 
sacerdote austero que, paradoxalmente, portanto, trata na prática como divino e se extasia com o conhecimento humano que despreza apenas teórica e nominalmente e não se guia, por não compreender, pelo conhecimento religioso que teoricamente absolutiza como divino, mas que despreza na prática de uma vida portanto equivocada, em que há enfim descompasso entre as palavras e as coisas, i. e., o personagem clérigo critica os profanos mas vive como eles, louva a doutrina cristã mas não a vive.

Esta caricata figura do clérigo sommelier e chef de cuisine, se torna uma triste figura na medida em que, se acredita sinceramente que há um conhecimento sagrado e revelado por uma divindade, mostra-se na vida não estar à altura do que acredita e julga compreender pois na realidade não o compreende, não pode explicá-lo porque não pode fundamentá-lo na razão e por isso não parece ser profundamente convencido por este conhecimento que permanece então extrínseco, envolto em uma aura de fantástico, de autoridade sobrenatural e distante como uma fria norma externa - permanente ocasião de fracassos chamados "pecados" de uma vontade abandonada pela razão e assim entregue a si mesma, às crenças e fantasias particulares. E esta figura se torna ainda trágica, pois, por ignorância, despreza, afasta e chama de "profano” justamente aquele conhecimento humano que teria recursos para seduzi-lo, convencê-lo humanamente a mudar, por etapas através de razões, imagens, apelos a sentimentos, emoções, valores, etc., voltando a unir pensamento e vida.

Erasmo aumenta o efeito dramático do breve episódio fazendo Batt se exasperar ao observar que naquele jantar ainda podia ver velhos sacerdotes se gabando de antigas proezas e obscenamente orgulhosos - Ferendum hoc quoque, si non inter epulas, senes, sola libidines fortes, antiqua sua facinora jactarente invicem - de terem feito aquilo que agora são velhos demais para fazer - et quod facere per aetatem nequeunt, fecisse se turpiter gloriarentur; devotos de orelhas muito delicadas que fogem de narrações da mitologia sedutora dos poetas pagãos e nos convidam a viver como os Apóstolos - Hi sunt, quorum aures poetarum fabulas religiose refugiunt, qui nos ad Apostolicos mores provocant $^{331}$.

\footnotetext{
${ }^{331}$ Idem, 1737 B.
} 
Cinco argumentos mostrando que os Apóstolos não eram rudes e que há inúmeros modelos de cristãos doutos; primeiramente o argumento de que os Apóstolos não eram rudes: indignado, o autor acusa os bárbaros afirmando que é uma impiedade, um despudor, uma difamação da ordem sagrada, ousar chamar de “rudes” os Apóstolos para defender a própria rusticidade e com isto esperar até merecer seus favores, pois estes não passaram em um piscar de olhos da pesca ao apostolado, do governo de um barco para o governo do mundo. Mais que lições e disputas de Platão, de Crisipo ou de outro filósofo quem seja, os Apóstolos assistiram por muito tempo às lições do próprio pai da Filosofia, testemunharam seus milagres e com ele conviveram e conversaram assiduamente. Além de tudo, como afirma Sêneca, a filosofia tem uma tal força que não faz bem apenas àquele que se dedica a ela inteiramente, mas até àquele que simplesmente entra em contato com ela, exatamente como quem, permanecendo algum tempo em uma perfumaria, ao sair, leva consigo seu aroma; efeito ainda mais forte ocorreu com os Apóstolos depois de serem tratados com familiaridade, apresentarem perguntas e viverem tanto tempo juntos de um mestre como Jesus, a própria fonte do saber. Ainda depois da ressurreição, Cristo permaneceu quarenta dias em companhia dos Apóstolos, aparecia continuamente aos seus discípulos, os alertava e aconselhava, ensinava-lhes sua doutrina. Também, mesmo depois de subir aos céus, lhes enviou o Espírito Santo que não lhes teria permitido ignorar nada mais $^{332}$. Não pode ser ignorante e rude alguém que com João escreve o sublime princípio do Evangelho: "No começo era o Verbo e o Verbo era próximo de Deus e o Verbo era Deus”; nem alguém como Pedro cujas cartas podem faltar em elegância, mas não em doutrina ou Tiago a quem se atribui uma carta não só plena de sabedoria, mas também portadora de eficácia expressiva ${ }^{333}$. Como cristãos, não devemos admitir que estes obtusos insultem continuamente estes homens celestes a quem devemos nossa salvação quanquam quis Christianae pietatis amator ferat ab ustis nebulonibus, toties insimulari viros coelestis et nostrae salutis auctores - especialmente se comparamos a nossa própria rusticidade com a ampla erudição destes: eles conheciam todas as línguas, nós conhecemos apenas nosso latim de crianças - Nempe illos Linguarum species omnes calluisse legimus,

\footnotetext{
332 Observe-se que o autor usa aqui a seu favor, em discussão derivada, justamente o argumento que deseja enfrentar na discussão principal. A aparente contradição se desfaz ao se lembrar que os fatos sobrenaturais que cita teriam acontecido segundo a Bíblia e não que realmente aconteceram.

${ }^{333}$ Erasmo da Rotterdam, Antibarbari, op. cit., pp. 204 a 206.
} 
nos unica vix balbutimus - eles foram oradores extraordinários capazes de comover os tiranos, de sacudir povos bárbaros e cruéis, nós somos mais mudos do que os animais irracionais - nos pecudibus ipsis fere mutiores - eles sabiam de memória os mistérios do Antigo e Novo Testamento, nós conhecemos apenas o alfabeto, somos perfeitos asnos e ainda nos arriscamos a dizer que os Apóstolos eram ignorantes - Nos vix prima litterarum elementa percepimus, et audemus postea homines ipsa ruditate rudiores, immperitus fuisse Apostolos dicere. ${ }^{334}$

O argumento que lembra a erudição profana de Paulo: este Apóstolo foi o único a introduzir também a erudição profana no apostolado e, sendo o único, tornou-se também o mais eminente desde que é esta superioridade intelectual que lhe garante o primado, pois se a fé era fervorosa para todos os Apóstolos, apenas Paulo, enquanto homem de cultura e grande orador, foi chamado de "vaso de eleição" e teve reconhecida sua capacidade de opor-se à douta escola de Atenas, de suportar a presunção dos filósofos e de submeter a eloqüência romana ao domínio de Cristo ${ }^{335}$. Mesmo comparando Pedro e Paulo, que são os dois membros mais importantes da ordem apostólica - e primo ordine praecipuos, Petrum et Paulum - lemos que Paulo era doutíssimo e Pedro, superior por autoridade, aceitou sem responder e se conformou com a reprimenda de Paulo pois este sabia mais - Paulus omnium litterarum refertissimum erat. Petrus auctoritate superior a Paulo reprehensus, scientiori et credidit, et paruit. Nós também imitamos o príncipe dos Apóstolos, mas da maneira mais equivocada - Imitamur hos, sed plane praepostere - não nos basta recusar ouvir os letrados, ignorantes como somos, nos permitimos mesmo atacálos sem motivo - Indocti litteratos ultro reprehendimus, quando parum est quod parere recusamus $^{336}$.

O argumento que mostra que os Apóstolos prepararam com cuidado seus discursos e escritos: deve-se ousar avançar a hipótese de que os Apóstolos em geral, mas especialmente Paulo pronunciou algumas vezes discursos cuidadosamente preparados e talvez mesmo escritos previamente - cum reliquos Apostolos, tum vero Paulum meditata et

\footnotetext{
${ }^{334}$ Desiderii Erasmi, LB, X, op. cit., 1739 F a 1740 A.

${ }^{335}$ Erasmo da Rotterdam, Antibarbari, op. cit., p. 205.

${ }^{336}$ Desiderii Erasmi, LB, X, op. cit., 1739 E.
} 
fortassis scripta oratione nonnunquam dixisse - como se pode conjecturar a propósito de sua apologia contida nos Atos dos Apóstolos - ex ejus defensionibus, quae sunt in Actibus Apostolorum. De outra parte, também as epístolas de Pedro, de Tiago e João não parecem de fato escritas sem nenhuma preocupação de ordem estrutural e de eficácia expressiva tum neque Petri, neque Jacobi, neque Joannis hujusmodi sunt Epistolae, ut sine cura scriptae videri possint ${ }^{337}$.

O argumento que invoca exemplos de líderes, profetas e cristãos que foram doutos nas ciências profanas: se o comportamento de muitos é um critério - si id recte fit quod multorum fit exemplo - temos muitos modelos de líderes, profetas e cristãos eruditos que podemos propor para serem imitados, a começar com Moisés, pois não se lê que tenha havido um chefe hebreu mais santo e instruído desde criança nas disciplinas egípcias - quid eo imperatore sanctius? Et hic omnem disciplinam Aegytorum a puero doctus legitur. Seu saber profano, como dizem - saecularis, ut vocant, eruditio - não lhe roubou a glória de ser o único dos mortais a merecer um tratamento direto de Deus $-e$ mortalium genere unus in Domini familiaritatem adscisci meruerit. Ninguém foi mais puro que Daniel - Daniele quid castius? - e o mesmo não se recusou em estudar a ciência dos Caldeus - et hic Chaldeis disciplinis non recusavit institui - e a tradição faz de Salomão alguém mais douto que seu próprio pai, já muito douto - Docto patre, doctiorem Salomonem accepimus - e Jó e todos os outros profetas não faltaram com a erudição segundo testemunhos de Jerônimo e Agostinho e da escrita de seus próprios livros - et Job, et omnes prope Prophetas, non illitteratus fuisse, cum Hieronymi Augustinique testimonio constat, tum ipsa scriptorum monumenta declarant. Mas para que não se diga que a ciência profana deixou de ser lícita desde que a Lei de Moisés deixou de ser válida - at ne cavillentur, id cum Lege Mosaica desiisse fas esse - deve-se lembrar do exemplo de Paulo e Dionísio, seu discípulo, cujo saber e elegância expressiva não precisam de testemunho quanta doctrina, quantaque fuerit eloquentia, ipsi sibi sunt testes. Quadrato, que ouviu a pregação dos Apóstolos, não esqueceu com este ensino o que já possuía de célebre erudição - eruditionem in primis admirandam illis praeceptoribus non dedidicit - e fez chegar ao imperador Adriano um livro tão bem composto que bastou sua autoridade para fazer parar a

\footnotetext{
${ }^{337}$ Idem, op. cit., $1741 \mathrm{C}$.
} 
perseguição cruel aos cristãos - tantae eruditionis, ut acerrimam in Christianos persecutionem suo ingenio sedaverit. O mesmo fez seu contemporâneo Aristides, seríssimo filósofo e sumo orador - aequalis Aristides Philosophus gravissimus, et idem summus Orator - e Justino que possuía também uma grande erudição filosófica, era muito preparado em todas as disciplinas liberais, colocou todo seu saber a serviço da causa cristã e chegou a sacrificar a própria vida - ad Christi tutandam Religionem nom modo eruditissimum vertit ingenium, verum etiam animam impendit. Clemente, preceptor de Orígenes, presbítero da Igreja de Alexandria, foi o mais culto de todos segundo Jerônimo, juiz de enorme erudição - judice viro omnium longe doctissimo Hieronymo - contribuiu amplamente com sua eloquência e seus escritos plenos de erudição à defesa do cristianismo, gravemente ameaçado então pelos ataques dos pagãos - ad sacrae Religionis defensionem (...) in summo discrimine versabatur, non parum adjumenti contulit tum eloquentia, tum libris eruditionis plenis. Mas seria contar os grãos de areia insistir em folhear todo o catálogo dos cristãos doutos - Sed plane arenas metiar, si hic tendam omnem eruditorum catalogum revolvere ${ }^{338}$.

Mas os devotos, como são, não apreciam a erudição, grande que seja se não é também religiosa - nihil quantumvis politum eruditionem movere potest, nisi fit idem pium - e protestam que Orígenes foi um herético, então siga-se em frente, pois não faltarão exemplos de santos homens: Cipriano é famoso por seu martírio e também por sua erudição profana, então sigamos suas pegadas - Cyprianus etiam martyrio, nec minus litteratura seculari clarus, hunc sequamur; quem é mais santo que Ambrósio? Com ele devemos competir - Ambrosio quid sanctius? Hunc aemulemur - Jerônimo e Agostinho são modelos de devoção e homens letrados então nos espelhemos neles - Hieronymo vel Augustino quid vel magis pium, vel litteratius? horum similes esse curemus ${ }^{339}$. Beda, monge de vida virtuosa e não priva de erudição - Beda Monachus (...) vitae probitate, et doctrinae non contemnendae - não desprezou as matérias que se ensinava nas escolas pagãs a ponto de não ter escrúpulo em tratar das figuras retóricas e de escrever versos - adeo scholasticas disciplinas non contemsit ut de schematis grammaticis et carminibus condendis scribere

\footnotetext{
${ }^{338}$ Idem, op. cit., $1737 \mathrm{D}$ a $1738 \mathrm{~A}$

${ }^{339}$ Idem, op. cit., 1738 B a C.
} 
non piguerit $^{340}$. Mais recentemente encontramos Tomás de Aquino, autor insigne que publicou comentários às obras de um filósofo pagão, Aristóteles - Thomas Aquinas, scriptor nobilissimus, in Aristotelem Ethnicum Philosophum commentarios edidit - e citou Cícero e os poetas clássicos tratando até de problemas teológicos como o Princípio Primeiro e a Trindade - atque adeo in ipsis Theologicis quaestionibus, ubi summo principio, de Trinitate disputat, Ciceronis ac Poetarum testimonia profert. Scotus não possuía, por certo, cultura literária clássica, mas foi sempre um professor - Scotus tametsi a Musis prorsus alienus fuisse videtur, scholasticus tamen est - e mesmo frente aos mistérios da teologia não pôde esquecer dos seus caros filósofos - ac ne in medis quidem mysteriis, et arcanis Theologiae, Philosophorum suorum oblivisci potest ${ }^{341}$.

O argumento de que os cristãos doutos não aprenderam as ciências profanas acidentalmente: Erasmo adverte que os bárbaros podem responder que os cristãos doutos aprenderam as disciplinas pagãs antes da conversão e quando eram crianças nondum Christiani, et pueri adhuc, litteris illis sunt imbuti - mas lembra que Jerônimo nasce de pais cristãos, recebe desde criança uma educação cristã e reconhece, mesmo se gaba, de ter freqüentado escolas de gramática e retórica - Si tamem inter Grammaticos et Rhetores educatum fatetur, imo gloriantur - no entanto esta distinção não importa pois mesmo quem estudou as disciplinas pagãs antes de ser batizado, continuou a se servir destas, não só como cristão mas também como bispo e mesmo já velhos - cum iis, quae ante baptismum didicerunt, non modo Christiani, verum et Episcopi et senes fint usi senão, devemos perguntar por que todas as suas obras estão cheias de citações pagãs - cur omnes libros suos Ethnicis litteris resperferunt? - e por que reivindicam conscientemente este hábito - cur ut recte factum defendunt? - pois se poderia dizer que se lhes fugiu o que não pretendiam fazer - taciti fecissent, ignoscendum potius quam imitandum videri potuisset - mas, ao invés, os escritores cristãos antigos afirmam ter agido bem e seguido autoridades reconhecidas - nunc et recte, et optimi cujusque exemplo fecisse se testantur. Por certo, Agostinho não era mais pagão quando escreveu um livro específico sobre cada uma das artes liberais - Augustinus ipse jam non Ethnicus, de singulis artibus liberalibus singula volumina scripsit - mas se alguém insiste que na época este era apenas um

\footnotetext{
${ }^{340}$ Idem, op. cit., $1738 \mathrm{~F}$ a 1739 A.

${ }^{341}$ Idem, op. cit., 1739 A.
} 
catecúmeno, deve-se lembrar-lhe que esta era a época em que como recruta Agostinho justamente se preparava para ingressar na milícia cristã e mesmo assim se ocupou de disciplinas pagãs - cogitandum quidem de studiis Ethnicis erat, cum novus tiro ad Christianam Religionem exercebatur. E mesmo admitindo que Agostinho tenha errado e pecado por ignorância pode-se perguntar por que então já velho e sábio não reconheceu e criticou o erro cometido - cur jam sanior et senior hunc errorem non reprehendit? - mas ao contrário admite tê-lo feito intencionalmente - consulto etiam a se factum fatetur ${ }^{342}$.

Cinco argumentos mostrando as vantagens dos studia Humanitatis para a religião, pois além de úteis não são condenadas; primeiramente o argumento da utilidade das disciplinas pagãs na defesa da nova religião: dentre estes doutos cristãos há milhares que se não houvessem socorrido a fé em dificuldade com a sua brilhante erudição - bis mille recensere possem quorum insignis eruditio nisi fidei laboranti succurrisset - talvez hoje ela não seria assim tão ampla e confirmada, e mesmo talvez já não existisse - neque ampla, neque ita confirmatam, fortasse et nullam haberemus - e todo este serviço foi prestado por textos onde se pode ver quanto conhecimento retórico, lingüístico, filosófico, histórico, da Antiguidade, compreensão do mundo latino, do mundo grego, dos autores clássicos - Quantum in his omnibus compositionis, Linguarum, Philosophiae, Historiarum, Antiquitatis, Latinitatis, Graecanitatis, Auctorum, quanta peritia. Erasmo chega a exclamar indignado que afinal tudo isto é ciência profana - et haec quidem Ethnica adhuc - no entanto, os bárbaros ainda tremem inseguros e sofrem de inquietude moral, cheios de escrúpulos a respeito de aprender as disciplinas humanas - postea trepidant isti discere disciplinas humanas - como se faltassem exemplos de cristãos de prestígio que o tenham feito - quasi desint quorum exemplo id faciant ${ }^{343}$.

O argumento da vantagem intelectual e artística oferecida pela erudição pagã: Erasmo, como renascentista e leitor de Valla, não se abstém de apontar precisamente onde está a superioridade dos autores antigos e dos Padres da Igreja frente ao período anterior ao seu e explica que depois da época da Igreja primitiva em que viveram os doutos cristãos do argumento anterior, a teologia lentamente perdeu sua clareza conceitual, sua

342 Idem, op. cit., 1738 D a E.
343 Idem, op. cit., 1738 A e C. 
elegância expressiva e o seu saber e, por assim dizer, enferrujou - post hos quidem nitor politiesque Theologiae sensim in deterius degeneravit, et non parum rubiginis coepit contrahere - por vários séculos não faltaram homens de cultura, mas assim como mais raros também tornaram-se inferiores aos estudiosos antigos - non defuerunt aliquot saecula docti, verum ut rariores, ita inferiores - e conclui dizendo que depois daquela época abundaram apenas os diligentes e meros copiadores - laboriosorum nunquam non fuit copia $^{344}$.

O argumento histórico: que se folheiem as crônicas antigas e se tomem em mãos os catálogos dos escritores ilustres - evolvant Veterum Chronica, evolvant eos qui de scriptoribus scripserunt illustribus - e se encontrará Orígenes, Gregório di Nazianzo, Didimo, João Crisóstomo e os latinos Lattanzio, Hilário e Severo, todos compuseram escritos apologéticos e trataram de questões dogmáticas - omnes prope ad unum qui in defendanda fide ac tractandis mysteriis scripturarum operam navarunt - receberam sólida formação clássica e profana e jamais a repudiaram - scolasticis fuisse disciplinis instructissimos. De todos estes, Jerônimo defende e admira a erudição pagã assim como a cristã, pelo que devemos refletir antes de desprezar o que este admirou - quorum omnium Ethnicam eruditionem, imo et Christianam effert ac miratur Hieronynus, ne nos contemnamus. Mesmo depois do testemunho da história, o autor lamenta que ainda assim, devotos inseguros como somos, nenhuma erudição acabada pode nos emocionar se não for igualmente pia e religiosa - at nos, qua sumus religione, nihil quantumvis politum eruditione movere potest nisi fit idem pium ${ }^{345}$.

O argumento instrumental: Erasmo também apresenta a ciência profana como um instrumento técnico-científico que não é bom ou mal em si mesmo pois tem seu

\footnotetext{
344 Idem, op. cit., 1739 A

345 Idem, op. cit., 1738 B a C.
} 
valor determinado pelo seu emprego social ${ }^{346}$. A partir deste topos, Erasmo faz a crítica aos autores então recentes e contemporâneos e acusa o fato de que o nível de erudição em geral caiu muito - et quid attinet vel recentiores vel vivos commemorare, quorum licet fit inferior multo eruditio - mas adverte que na sua época se continua a considerar melhor quem é mais preparado nas disciplinas profanas - is tamen inter ipsos videtur praestantissimus, qui secularibus doctrinis instructissimus fuerit - e conclui que muitos homens ilustres não possuíram erudição profana mas aqueles que a possuíam não deixaram nunca de utilizá-la haec summa est multis quidem summis viris non contigit eruditio saecularis at cui contigit, nemo non est usus - e não tiveram nenhum receio em adornar o templo dos cristãos com os ricos despojos dos pagãos - nemo veritus est Christianorum templum Ethnicis opibus exornare $^{347}$.

Em lugar anterior do seu Antibárbaros, o autor já havia evocado duas imagens para traduzir o argumento instrumental: a primeira é tirada do De doctrina christiana de Agostinho onde este depois de distinguir o conhecimento supersticioso - que inclui os malefícios, encantamentos, magia, sortilégios, leitura de auspícios, consulta aos mortos etc. que pressupõem a intervenção de espíritos malígnos - do conhecimento não supersticioso que compreende as ciências e as artes instituídas pelo Homem como as letras, os vocábulos, o uso lingüístico, as leis etc. e compara estes últimos aos objetos preciosos dos egípcios que no Livro do Êxodo os hebreus, guiados por Moisés e preparando secretamente sua fuga da servidão, emprestaram de seus vizinhos e levaram consigo; esta fuga e este furto foram feitos sob conselho de Deus e então a Divina Providência já prevenira o escrúpulo - Scilicet jam tum divina providentia quorundam trepidationi consulebat - daqueles que teriam alguma reserva em depredar o Egito, i. e., apropriar-se da erudição pagã, sem o exemplo anterior de tantos generais e líderes - qui fortasse Aegypitum

\footnotetext{
${ }^{346}$ Luca D`Ascia em op. cit. p. 53, aponta Valla como o campeão, no século XV, da divulgação do argumento instrumental, como expresso no proêmio do quarto livro do seu Elegantiae, que o comentador chama de "defesa técnica”; mas esta noção da erudição como meio cujo valor depende de quem a utiliza, pode ser remontada à concepção ciceroniana do valor neutro da retórica como exposto logo no início do De Inventione, op. cit., pp. 8 e 9: “Assim, ao menos do meu ponto de vista, não se deve negligenciar o estudo da eloqüência em razão do abuso de que dela fazem alguns personagens nos negócios públicos e privados, mas ao contrário (...) - Quare meo quidem animo nihilo minus eloquentiae studendum est, etsi ea quidam et privatim et publice abutuntur, sed eo quidem vehementius (...)”.

${ }^{347}$ Desiderii Erasmi, LB, X, op. cit., 1739 B.
} 
spoliare, hoc est, Ethnicorum sapientiam usurpare timuissent, nisi hujus rei tantum imperatorem, tantum ducem, tantum exemplum habuissent. ${ }^{348}$.

A segunda imagem é tirada da epístola Ad Magnum oratorem urbis Romae de Jerônimo onde, à pergunta "por que citar os autores antigos contaminando a pureza da Igreja com a sujeira pagã” responde com um comentário ao Deuteronômio e compara a mulher estrangeira capturada à ciência profana, pois nesta passagem há o preceito divino de que a mulher nesta condição, antes de ser esposada - habendam conjugio - e tornada hebréia deve ter seus cabelos, sobrancelhas e pêlos raspados e as unhas cortadas para que seja purificada - Legerat in Deuteronomio, Dominis voce praeceptum, mulieris captiva radendum caput, supercilia, omnes pilos et ungues corporis amputandos. Esta passagem seria uma exortação para que não se evite a erudição pagã, mas se tome a precaução de purificá-la para integrá-la à erudição cristã - nullas ethnicas litteras fugiamus, sed repurgatas, ad Christianorum eruditionem transferamus ${ }^{349}$ Uma terceira imagem patrística emprestada agora de Basílio pode ser encontrada nos escritos erasmianos: como as abelhas voando sobre as flores deixam o veneno e sugam apenas o suco salutar, assim os cristãos devem ler os autores pagãos ${ }^{350}$. A abordagem instrumental volta a ser feita mais adiante quando Erasmo parece trazer outro imparcial motivo técnico-prático para o emprego da arte retórica pelos teólogos e clérigos ao afirmar que se os nossos afetos e as nossas emoções estivessem em nosso pleno poder - Si nobis esset in manu, quos vellemus animorum motus - se pudéssemos modificar ao nosso arbítrio os sentimentos dos outros, seria completamente absurdo aprender a retórica - et sumere nobis, et aliis excitare, sine causa rhetorum praecepta disceremus ${ }^{351}$.

O argumento da falta de reprovação à ciência profana: raciocinando em negativo, Erasmo aponta a notável ausência de expressa condenação bíblica ao conhecimento pagão perguntando, se os Apóstolos não tiveram a ciência profana, se então

\footnotetext{
${ }^{348}$ Idem, $1732 \mathrm{C}$.

${ }^{349}$ Idem, 1729 E e F

${ }^{350}$ Jacopin, Paul, Lagrée, Jacqueline; op. cit. p. 65.

${ }^{351}$ Desiderii Erasmi, LB, X, op. cit., 1744 A.
} 
alguma vez a criticaram - non percalluerunt ${ }^{352}$ seculares disciplinas apostolli, at nunquid reprehenderunt? - e desafia os bárbaros a mostrar-lhe uma passagem da Bíblia onde os letrados são excluídos das primeiras comunidades cristãs - num quando litteratus a suo contubernio exclusisse leguntur? $?^{353}$.

Erasmo então se antecipa e faz a exegese da importante passagem evangélica em que o próprio Jesus parece proibir seus discípulos de preocuparem-se sobre o que deveriam dizer na presença de reis e governantes - Sibi vult, quod ipse suos discípulos sollicitos esset vetat, quid coram regibus atque praesidibus essent dicturi - pois lhes seria dado do céu aquilo que deveriam dizer - Dabitur enim inquit, vobis in illa hora quid loquamini - desde que então não seriam mais os Apóstolos que falariam, mas o Espírito do Pai que falaria através deles - neque enim vos estis qui loquimini, sed Spiritus Patris vestri qui loquitur in vobis - a esta passagem se soma o que Pedro escreveu afirmando que os homens de Deus falam inspirados pelo Espírito Santo - quid quod Petrus Spiritu Sancto instructos loqui Dei homnis, scripsit. Diante destas duas passagens bíblicas que parecem reprovar o tempo gasto em estudo e a preparação intelectual por esforço próprio, o autor pergunta se nestas passagens citadas, Cristo tenha realmente proibido aos Apóstolos, que deveriam falar com os príncipes, de preocuparem-se com os conteúdos de seus discursos - num tibi Christus istis verbis, quae modo recitasti, discípulos deterruisse videtur ne apud príncipes dicturi quid essent dicturi cogitarent - pois só um louco faria assim desde que Cristo enquanto homem se preparou sempre antes de falar - quod nemo nisi phreneticus non fecit, cum Christus ipse quatenus homo erat, non sine praemeditatione fit locutos - então não quis insinuar aos Apóstolos, homens prudentes, um escrúpulo exagerado que lhes teriam criado incertezas e ansiedades, mas ao contrário, encorajá-los non igitur apostolis, quod prudentis hominis proprium videtur, sed metum adimere studui para que estes, homens simples e despreparados, não tremessem ao falar com os príncipes doutos e eloqüentes - ne quid homines contemti, et imperiti, apud príncipes, et doctos, et facundos dicere trepidarent - o que costuma intimidar mesmo os maiores e mais exercitados oradores - apud quos summi et exercitatissimi oratores solent exalbescere. Em

\footnotetext{
${ }^{352}$ Este verbo Percalluerunt - calejaram completamente - reforça a idéia da erudição como resultado do esforço e obra humana.

353 Desiderii Erasmi, LB, X, op. cit., 1739 E e F.
} 
efeito, Cristo não teria abandonado quem sustentaria sua causa e quis com esta frase, não proibí-los de preparar-se, mas encorajá-los - Se enim non deserturum patronos suos, ipsi modo magno animo essent - portanto, não quis prejudicar ou diminuir a sua lucidez e presença de espírito mas aumentar-lhes a confiança em suas próprias forças - ergo non industriam et vigilantiam interdicere, sed animum addere voluit ${ }^{354}$. Em um terceiro momento, no final de seu Antibarbaros, Erasmo mostra que a Bíblia não condena a ciência profana fazendo a exegese da passagem que proíbe de nos preocuparmos com o alimento que comeremos no dia seguinte, pois ali não há qualquer veto à busca da sabedoria - nam vetamur Evangelica voce, de crastino victu, vestituve esse solliciti, nusquam sapientiam quaerere prohibemur - e observa, não sem alguma acidez, que não se considera uma culpa poupar, acumular ganho, semear, construir - nec vitio tamem vertitur, quod non modo in crastinum, verum etiam in multos annos parcimus, quaerimus, serimus, aedificamus - não apenas para o dia seguinte, mas para períodos muito mais longos - non nostrae modo vitae, verum etiam posterorum consulentes - e pergunta então por que seria um pecado aspirar aos frutos da sabedoria que valem muito mais - et vitio dabitur, si quis idem in quaerenda sapientia fruge longe meliore facit ${ }^{355}$. Ainda, Erasmo reconhece que o Espírito Santo não infundiu o saber profano em ninguém, mas desafia perguntando por que o mesmo não tirou este saber de Paulo e por que não vetou seu uso - nemini infudit, inquit, donemus istud, at cui unquam ademit? Cur uti non vetuit? - acrescentando que seguramente lhe teria proibido se quisesse que o considerássemos nocivo - vetiturus utique, si perniciosas videri voluisset ${ }^{356}$.

Seis argumentos afirmando a responsabilidade do Homem mesmo na hipótese de que o saber profano possa ser inspirado divinamente: primeiramente o argumento de que mesmo que verdadeira, a inspiração divina do conhecimento profano seria exceção que não dispensa o esforço individual: antes de discutir a hipótese da inspiração divina da ciência pagã, Erasmo procura reduzir sua importância apontando a raridade dos casos reais em que ela é supostamente observada e cita a obra De Doctrina Christiana de Agostinho para extrair a narração de um caso famoso em que alguém sem

\footnotetext{
${ }^{354}$ Idem, 1740 F a 1741 B.

${ }^{355}$ Idem, $1741 \mathrm{E}$.

${ }^{356}$ Idem, 1743 E.
} 
esforço acabou por possuir uma vasta erudição - Addit ibidem vulgo jactatam fuisse fabulam, de nescio quo, cui citra humanam operam litterarum peritia contigerit - e Agostinho não teria perdido tempo em confutá-lo, mas lhe atribui pouquíssima importância - quam ille quidem non magnopere confutat: parvi tamem ducit - mesmo se tivesse sido verdade, ninguém poderia ter garantia de possuir a mesma sorte - propterea quod etiamsi maxime vera fuisset, non cuivis idem sperandum esset - em conclusão postula que aquele feliz caso isolado não deve nos desviar do esforço consciente em obter a erudição - nec putat illius unius felicitatem nos ab industria debere avocare - pois, seria tolo, ou pior, insolente - aut stulti, aut quod foedius, arrogantis - pedir ao sopro celeste do Espírito Santo alguma coisa que se poderia aprender muito bem procurando um professor - nam quod commode possis ab homine doceri, id e coelesti afflatu praestolari ${ }^{357}$.

O argumento contra a idéia de uma permanente assistência intelectual divina fundada no Evangelho: para continuar a idéia de que a possibilidade da ciência profana ser inspirada não desobriga ninguém ao estudo, Erasmo passa a tratar do caso sempre lembrado do Apóstolo Paulo que teria recebido revelações divinas em um evento sobrenatural. O autor torna favorável para si o argumento freqüente de seus adversários lembrando que se este Apóstolo teve o privilégio de ser transportado misticamente ao terceiro céu - Paulum ipsum, cui in tertium usque coelum rapi contigit - ele ainda assim pediu por carta que lhe mandassem alguns manuscritos e depois os examinou com Pedro libros qui in membranis essent per litteras petisse ac postea cum Petro - e outros Apóstolos para melhor ajuizar sobre algumas questões de fé - caeterisque apostolis de fidei doctrina contulisse - e lembra que mesmo os Apóstolos tiveram freqüentes discussões - apostolos ipsos non semel inter se de Religione nova communicasse - e que Pedro foi corrigido por Paulo à viva voz - Petrum Pauli voce castigatum. Erasmo provoca e pergunta onde o Espírito Santo descansava naquele momento - Ubi tunc cessabat Spiritus Sanctus? - e ainda por que deixava Paulo ler, Pedro errar e que todos os outros tivessem dúvidas como este - Cur legere Paulum, cur errare Petrum, cur haerere omnes sinebat ${ }^{358}$. No entanto, o corolário deste argumento é encontrado apenas mais à frente: não podemos ficar

\footnotetext{
${ }^{357}$ Idem, $1740 \mathrm{~F}$.

${ }^{358}$ Idem, 1742 C.
} 
a esperar o Espírito Santo pois precisamos das disciplinas liberais - nec ille nobis Spiritus est exspectandus, disciplinis liberalibus opus est. ${ }^{359}$

O argumento de que pedir sabedoria para Deus não desobriga ao estudo: o autor deve enfrentar outra convicção do senso comum que desvaloriza o esforço individual do estudo, pois é seduzido pela atração do que é maravilhoso, pelo conforto do providencialismo, acreditando que basta pedir a Deus a sabedoria necessária para obtê-la como se pode entender inadvertidamente na passagem da epístola de Tiago que diz que aquele que tiver necessidade de sabedoria pode pedi-la a Deus pois ele a dá a todos em abundância e não recrimina - Qui indiget Sapientia postulet a Deo, qui dat omnibus abundanter, et non improperat ${ }^{360}$. Erasmo então, repetindo sua estratégia usual de não resistir à força, mas desviá-la, aceita a fórmula costumeira, a proposição vulgar, a opinião geral, mas matizando sua significação sempre em favor da importância da iniciativa humana; assim, aceita que devemos pedir a Deus a sabedoria, mas exige que se compreenda corretamente como fazê-lo - Postulanda est a Deo sapientia, accedo, at quomodo postulanda? - pois devemos pedi-la como fazemos a propósito do alimento, do vestuário e de outras coisas de que o homem tem necessidade para viver - nempe ut victus ut vestitus, ut caetera humano usui necessaria. É um preceito que devemos pedir a cada dia o nosso pão quotidiano - Jubemur a Deo panem quotidianum quotidie petere - e de fato este nos é dado diariamente, mas não sem fazer nada - et datur quidem quotidie, at nunquid oscitantibus? - Pedimos o que vestir e o recebemos, mas trabalhando - Vestitum petimus, praestatur, sed laborantibus - e do mesmo modo pedimos a sabedoria sem que isto implique qualquer desvalorização do esforço humano - Hac ratione sapientiam quoque postulamus, at ita, ut de humana industria nihil diminuamus. E pergunta: ou os bens do corpo são obtidos apenas com o esforço, enquanto aqueles da alma recebemos gratuitamente? - An vero quae corporis sunt, non nisi industria tua tibi obveniunt, quae animi sunt bona, gratis accipies? - Recebe o pão apenas quem se esforça em conseguí-lo e a sabedoria deveria ser inspirada durante o sonho? - Panis nisi sudanti non praestatur, sapientia dormienti infuditur? - se considera um miserável, um assassino de si mesmo quem se deixa morrer de fome esperando que lhe caia o maná do céu - Perditus et ${ }^{359}$ Idem, 1744 A.
${ }^{360}$ Idem, 1741 A. 
homicida sui judicatur, qui coelestem alimoniam exspectans, fame mori maluit - ao invés de escapar da morte comendo o pão que é fruto do trabalho humano - quam pane humano labore quaesito, mortem effugere - e se deveria tomar por um homem santo quem preferiria a vergonha da ignorância ao útil ensinamento dos homens? - et religiosus habebitur, qui turpiter nescire praeoptet magis, quam ab homine salutarem doctrinam accipere ${ }^{361}$. Erasmo conclui este raciocínio com o seguinte corolário: o Evangelho não nos proíbe de trabalharmos para ganharmos o pão - Illic sanam interpretationem admittimus, non quaerendi panis industriam nobis interdictam esse - mas nos exorta a evitar uma ânsia mesquinha e injustificada pelo nosso futuro - Sed inanem et anxiam sollicitudinem ${ }^{362}$. Um pouco mais adiante, o autor lembra que uma profecia havia prometido para Salomão a sabedoria e a seu pai o reino de Israel - Promissa erat sapientia coelesti oraculo Salomoni, promissum erat patri regnum Israeliticum - mas nem um nem outro confiaram excessivamente na profecia - neuter tamen ita oraculo confisus est - Davi não poupou nenhum esforço humano para mostrar-se digno do favor divino - ut vel hic quicquam humani conatus praeterierit, quo se dignum praestaret - enquanto Salomão continuou a estudar com o mesmo empenho de antes - vel ille sapientiam languidiore studio quaesiverit $^{363}$.

O argumento de que a ajuda de Deus exige a contrapartida do homem: esta é outra abordagem que visa a mesma valorização da iniciativa e esforço intelectual individual, mas que toma a seu favor uma opinião do senso comum baseada na práxis mercantil e que supõe para a relação com a divindade o mesmo critério de equilíbrio ideal nos negócios entre os homens; na esteira da citação dos célebres talentos de Davi e Salomão, Erasmo observa que estes entendiam de fato como verdadeiramente profundo intelligebant nimirum quod gravissime a quodam scriptum est, o ditado que afirma que Deus nos vende tudo em troca de nossa fadiga - Deos omnia nobis laboribus vendere. Tudo será dado para quem trabalha - Dabunt igitur, sed laboranti - mas acumularão sabedoria só aqueles que se empenham -addent sapientiam, sed annitenti - garantirão sua continência só aqueles que se esforçam por possuí-la - praestabunt continentiam, sed

\footnotetext{
${ }^{361}$ Idem, $1741 \mathrm{C}$ a D.

${ }^{362}$ Idem, $1741 \mathrm{E}$ a F.

${ }^{363}$ Idem, $1741 \mathrm{~F}$.
} 
conanti - serão ensinados só aqueles que estudam e serão ajudados, mas só aqueles que lutam - docebunt, sed studiosos; adjutabunt, sed dimicantes. E Erasmo conclui em tom severo: não serão abandonados a não ser aqueles que faltam para consigo mesmo Neminem deferent, ita quidem, nisi ipse sibi defuerit ${ }^{364}$.

O argumento de que se o conhecimento pagão é ocasionalmente obtido por inspiração divina, então se segue que ele é algo bom e desejável e deve ser buscado pelo estudo: esta é uma conseqüência inescapável para quem, fugindo do esforço do estudo, quer e acredita que pode receber o conhecimento dos estudiosos por inspiração divina. Erasmo extrai esta conseqüência acrescentando que, se seus adversários insistem que os autores eclesiásticos obtiveram sua erudição através de rezas e não com o estudo - si maxime pugnant, sacros scriptores orando eam eruditionem esse consecturus - é possível devolver contra eles o mesmo argumento - jam ipsi nobis laqueum, quo capiantur, ministrant ${ }^{365}$. De fato, se dizia que São Bernardo, santo homem e escritor de erudição e estilo - divum Bernardum, praeter sanctitatis laudem, virum ex recentioribus nec indoctum (...) - com as próprias palavras teria reconhecido que não teve por mestres outros que não os carvalhos sob os quais se sentava - ipsum fateri, se Quercubus et Fagis usum pro magistris $^{366}$. Ora, se São Bernardo teve uma erudição não só filosófica, mas também poética e assim certamente profana - Cum enim divus Bernardus litteris non modo philosophicis, verum etiam poeticis instructus fuerit, utique profanis - deve-se então perguntar como é possível criticar aqueles que se esforçam para obter com os próprios meios aquilo que o Espírito Santo inspirou a poucos eleitos - quis jam ausit nos reprehendere, quod id nostra industria conemur assequi, quod coelestis ille Spiritus aliquot felicibus impartivit? Então, se a erudição pagã pode ser um dom do Espírito Santo, logo é algo de bom e de desejável - Si Ethnicorum eruditio Spiritus Sancti munus est, igitur bona atque expetenda - porque Deus não é causa dos males -malorum enim non est auctor Deus $^{367}$. Mas ressalte-se que Erasmo trata aqui, como sempre, da inspiração divina de ciência profana de maneira condicional como hipótese.

\footnotetext{
${ }^{364}$ Idem, 1741 F a 1742 A.

${ }^{365}$ Idem, 1743 C.

${ }^{366}$ Idem, $1742 \mathrm{E}$.

${ }^{367}$ Idem, $1743 \mathrm{C}$ a D.
} 
O argumento de que, nos casos em que se alega a inspiração divina, esta reconhece o esforço individual já feito e então ela é complementar: depois de apontar a diferença entre a preparação intelectual de Paulo e a de Pedro, a diferença entre a eloqüência de Tiago e Pedro e a vantagem de João sobre os outros evangelistas e lembrar que também os doutores da Igreja revelam enormes diferenças de estilo e erudição, Erasmo nota que se ocasionalmente entre os primeiros cristãos a sabedoria foi divinamente inspirada, esta não ocorreu de maneira uniforme e que se a divindade que a inspirou é a mesma então é evidente que o Espírito Santo não encontrou em todos o mesmo grau de erudição e que portanto este faz crescer e desenvolver a parte da nossa atividade humana Auget enim ille, quae nostrae peperimus industria - promove os nossos estudos, encoraja os nossos esforços - promovet studia nostra, adspirat nostris conatibus. Erasmo, pedindo licença ao leitor para introduzir um exemplo tirado dos mitos pagãos a título de ilustração Quod si fas est hoc loco Poetarum fabulas admiscere - propõe que devemos imitar Prometeu - Prometheus est nobis imitandus - que ousou pedir aos astros que insuflassem vida na estátua de barro que havia plasmado - qui simulacro illi suo luteo, vitam ex astris ausus est petere - mas só depois de haver colocado naquele trabalho todos os artifícios humanos conhecidos - Sed tum demum ubi quicquid humano artifício praestari potuit, adhibuisset. Desta imagem, será tirado um ensinamento de aparente interesse da religião e da erudição, mas ancorado em um argumento moral que valoriza e preceitua o esforço intelectual individual e acusa o fato de que nós, diferentemente de Prometeu, oferecemos ao Espírito Santo uma matéria disforme e esperamos que, enquanto dormimos, este faça tudo por nós - nos rudem massam offerimus, et Spiritum omnia nobis dormientibus confecturum speramus $^{368}$.

Logo à frente, depois de lembrar que Paulo, mais erudito que os demais Apóstolos, discutia freqüentemente com estes para melhor ajuizar sobre as questões de fé, mesmo depois de ter sido levado misticamente ao terceiro céu, Erasmo insiste em observar que os dons do Espírito Santo não tornaram supérflua a atividade humana, mas a ajudaram e a integraram - Videtis ut operam humanam Spiritus hujus munus non excluserit, sed adjuverit - e faz a ressalva de que esta ação divina foi ocasionalmente presente em forma

\footnotetext{
${ }^{368}$ Idem, 1742 B.
} 
sobrenatural - Adfuit tamen nonnunquam prodigioso quodam more - segundo a narrativa bíblica, ressalte-se, mas apenas quando a situação claramente exigia um milagre e o esforço humano riscava não ser suficiente - Sed tum demum, cum aut miraculum res expostuaret, aut studium humanum vinceretur ${ }^{369}$.

No entanto, esta exegese é surpreendentemente seguida, em um lugar pouco mais à frente, pela contrastante, desencantada e taxativa proposição de que a erudição de cada um é proporcional - Nihilominus tantum unumquemque eruditione valuisse videmus - à inteligência natural e ao empenho no estudo - quantum ingenio polluisset, quantum studio contendisset - e ajuíza que muitos receberam gratuitamente a inteligência, que é um dom da natureza - Ingenium et indoles multis contigere gratis sunt enim naturae dotes - mas que a virtude e a erudição não são jamais presenteadas - virtus et eruditio nullis. Ora, então há finalmente um evidente posicionamento do autor contrário à concepção geral de que, assim como muitos podem nascer com talento e índole - ingenium et indoles - assim também poderiam por inspiração divina obter instantaneamente a virtude e a erudição: em uma curta sentença, o autor recusa esta concepção geral e postula que a inteligência e o caráter são dons da natureza - naturae dotes - enquanto virtude e erudição - virtus et eruditio - por exclusão, pertencem ao campo do esforço pessoal - studio - então, à liberdade da iniciativa humana; há, portanto, uma diferença entre a ambição e comodismo de quem pede um grande presente e todo gratuito, o que Erasmo recusa, e a possibilidade de ação sobrenatural que pode ser julgada necessária pela Divina Providência - Divino Consilio $^{370}$.

Doze argumentos finais para a refutação in totum da noção geral de inspiração divina baseada na separação entre o saber humano e o saber divino; primeiramente o argumento circunstancial: contra a idéia da inspiração divina, Erasmo toma imprevisivelmente a seu favor o argumento dos seus adversários que repetem que os fundadores do cristianismo foram pessoas rudes, e afirma que se deve cuidar para não ter medo de que a religião cristã tenha sido fundada por pessoas rudes - at non temere curatum est, ut Christiana religio a rudibus auctoribus initium caperet - era oportuno à época para

\footnotetext{
${ }^{369}$ Idem, $1742 \mathrm{C}$.

${ }^{370}$ Idem, 1742 D.
} 
que não se atribuísse o mérito à atividade humana - istud quidem recte, ne scilicet tanti facti gloria penes humanam esset industriam - mas que tudo dependesse da graça divina sed omnis divinae virtuti tribueretur.

Note-se que Erasmo, utiliza um torneio especial ao apresentar como aceitável uma noção que não aceita pessoalmente, para obter o convencimento em uma idéia mais importante, pois não concorda com a noção de que os Apóstolos eram rudes, mas diz que "não se deve temer que eles sejam rudes" e não que "foram rudes". A seguir, coloca uma pergunta crucial, paradigmática para um renascentista: naquele tempo isto era apropriado, mas o que isto tem a ver com o nosso? - ea res illi quidem tempori erat apta, verum quid ad nos? - e avança afirmando que sua época contemporânea exige costumes diferentes, formas diversas de vida - hic dies aliam vitam, alios mores postulat ${ }^{371}$. O autor também recorre ao mesmo raciocínio apoiado em circunstâncias quando deve enfrentar o senso comum que acredita que a erudição pode ser obtida por intervenção divina, o que desvalorizaria os esforços dos estudiosos em prol da superstição; então, para melhor atacála, admite a idéia como hipótese aceitando que a sabedoria teria sido infundida aos Apóstolos sem concurso humano - at apostolis sine mortali opera sapientia infusa est. Demus istud - também os hebreus, durante a travessia do deserto receberam do céu o maná com que se alimentaram como lemos na Bíblia - Hebraeis in cremo ab aethere cibum depluisse legimus - mas como seria ímpio pretender que o céu nos forneça hoje milagrosamente aquele maná - sed quam impium est velle manna illud e coelo praestolari assim também seria ímpio, ou talvez pior, esperar sem nada fazer que a sabedoria ${ }^{372}$ descesse das nuvens sobre nós - tantundem aut etiam magis impium fuerit, apostolorum more Sapientiam e nubibus otiosos expectare ${ }^{373}$.

O argumento da distribuição desigual dos casos narrados de inspiração divina: Erasmo não deixa escapar aquilo que foge a muitos crentes na inspiração divina e pergunta por que o Espírito Santo não a distribui uniformemente - Cur non aequam

\footnotetext{
${ }^{371}$ Idem, 1739 E.

372 Exemplo do uso permutável que o autor faz dos termos “sabedoria”, “ciência”, “conhecimento”, “saber” e “erudição” buscando claramente a unificação do que se sabe por verdade.

${ }^{373}$ Desiderii Erasmi, LB, X, op. cit., 1741 D e E.
} 
omnibus partem immisit? Admitindo agora - sempre por hipótese - que a sabedoria dos Apóstolos tenha sido inspirada - Jam dedimos Apostolis infusam sapientiam - sem considerar os contínuos ensinamentos que receberam antes e depois da ressurreição de Cristo que é o mestre supremo - mitto enim quod ante resurrectionem, et post resurrectione assiduis praeceptionibus ab optimo doctore Christo sunt formati - nem a continua leitura e discussões da Bíblia que praticaram entre eles - mitto quod apud se assidue legerinte, et inter sese de scripturis contulerint - Erasmo apresenta, no entanto, uma série de dificuldades decorrentes da heterogeneidade da atividade intelectual dos Apóstolos: por que Paulo foi mais culto que Pedro? - cur plus sapuit Paulus quam Petrus? - por que Tiago é mais eloqüente que Pedro? - cur facundios est Jacobus Petro? - por que João escreveu mais divinamente que os outros evangelistas? - cur divinius scripsit Joannes caeteris Evangelistas? - por que entre os sacros doutores se revelam tantas diferenças de erudição, de talento e de estilo? - cur in caeteris sanctis Doctoribus alius est alio eruditior, alius alio facundior? - pois afinal, a divindade que os inspirava era a mesma - Eodem certe numine instructi scripserunt ${ }^{374}$.

O argumento da inutilidade: o esforço no estudo seria inútil se o conhecimento profano pode ser, e a ciência divina só é, obtida por inspiração divina. O personagem Batt, permanente porta voz de Erasmo, enfrenta frontalmente a opinião do senso comum e dos teólogos que apelam para a distinção entre ciência profana e ciência divina, sempre que é demonstrado que os Apóstolos não eram ignorantes, mas oradores, escritores, falavam outras línguas e tiveram o próprio Cristo por anos inteiros como mestre.

Esta opinião geral assume que o Homem pode chegar a tocar e conhecer os assuntos divinos, mas involuntariamente, apenas por inspiração do Espírito Santo, alcançando conteúdos distintos do conhecimento humano, pois é presenteado do alto por um conhecimento de uma outra natureza - eam ipsam non humano studio, sed coelesti munere sunt consequuti - então a superioridade intelectual dos Apóstolos se fundaria na inspiração divina e não no seu esforço de aprendizado e no magistério de Jesus. Erasmo localiza, esta opinião especialmente entre teólogos que ele chama de medíocres - istud

\footnotetext{
${ }^{374}$ Idem, 1742 de A e B.
} 
enim ipsum ineptus aliquis Theologus fuerat responsurus - que recorrem sempre a esta escapatória quando se contrapõe a sua ignorância, à eloqüência de Jerônimo, à erudição de Agostinho e à literatura antiga - hic enim confugiunt, quoties eis Hieronymiana facundia, Augustini eruditio, et Veterum litterae objiciuntur - e exclamam que estes foram inspirados pelo Espírito Santo - Istis enim, inquiunt, coelestis spiritus ministravit.

O autor se exaspera com esta resposta dos medíocres que separam o profano do divino para explicar a superioridade dos Apóstolos, mas que misturam estes mesmos conhecimentos para explicar a superioridade dos doutores, e se admira que estes teólogos, por terem estudado lógica, se vêm como monstros de sutileza - equidem admirari soleo in homminibus, qui sibi perquam acuti videntur, quippe Dialectici - possam argumentar tão estupidamente, a menos que o façam de má fé - tam hebes ingenium, nisi forte perperam ista faciunt. Parece que Erasmo compreende que o argumento da inspiração divina reivindica silenciosamente e implica em uma cadeia de razões diferentes daquela dos conhecimentos humanos, o que tornaria impossível que o Homem, fazendo progredir seus conhecimentos na mesma cadeia chegue um dia a compreender ou alcançar um conhecimento divino que pertence a outra; a conseqüência lógica seria a impossibilidade dos dois conhecimentos, humano e divino, serem traduzidos um para o outro, se comunicarem, se espelharem, colaborarem.

Aquele mesmo tom exasperado é mantido diante dos desdobramentos práticos e morais da assunção acrítica e reflexa de que os conhecimentos humanos não são da mesma natureza dos divinos e Erasmo então pergunta onde querem chegar seus adversários teólogos, pois devemos talvez concluir que não devemos aspirar ao saber se este não vem infundido por graça divina - quid enim ista tandem oratione sibi volunt? an nullam nobis exspectandam scientiam, nisi quae coelitus infudatur? - então não nos serve de nada nos esvairmos nos estudos dia e noite? - Se frustra igitur nocturnis diurnisque studis maceramur? - e para que serve então as escolas, na sua maioria pública, as esplêndidas bibliotecas? - quorsum autem attinet Ludi litterari et quidem publici, quorsum tot suntuosae Bibliothecae? Por que consumimos em vãs elucubrações os nossos melhores anos ou mesmo toda a vida? - quid meliores annos, atque adeo totos, insanis 
lucubrationibus consumimus? - Por que arruinamos a saúde sem motivo, por que, sem motivo, envelhecemos sobre livros? - quid frustra pallemus, frustra libris insenescimus? A resposta de Erasmo é de uma ironia que beira ao sarcasmo: voltemos à razão ainda que tarde, aceitemos a lição e mudemos de vida - respiscamos vel sero, et moniti meliora sequamur - deixemos as fadigas inúteis - missus faciamus inutiles labores - pois esta gente astuta nos indica o caminho curto - compendiariam viam, astutum hoc genus hominum indicat - nos entreguemos à boa vida, gozemos do vinho e do sono, como diz Horácio nos cutem curemus, ac vini somnique benigni, ut ait Flaccus - e deixemos que os céus trabalhem até que desça sobre nós, que estamos aqui bocejantes e felizes sem fazer nada, aquele espírito etéreo - coelitus exspectemus, donec oscitantibus nobis spiritus illabatur aethereus - e depois, como se tivéssemos bebido da fonte das musas na Beócia ${ }^{375}$ improvisemos como teólogos - ac deinde perinde a fonte Aonio poti repente theologi profiliam $^{376}$.

Fazendo um mea culpa mais adiante, Erasmo explicará qualquer possível excesso queixando-se que é impossível exagerar quando se tem adversários tão arrogantes Quid autem acerbum in homines tam arrogantes dici potest - ao ponto de reivindicarem uma inspiração celeste, desprezando os nobres esforços dos outros, quando não sabem absolutamente nada - qui contemtis aliorum egregis laboribus ipsi cum nihil sciant - mas sua contenção logo se desfaz e através de seu personagem Batt descarrega novas observações calcinantes afirmando em seguida que, como literato, não arriscaria provocar estas mentes divinas - ne ego quidem homo Poeticus auderem istos Deos lacessere - se não houvesse antes começado Agostinho a rir da loucura destes no prefácio ao De Doctrina Christiana - ne divus ipse Augustinus in praefatione in libris de Christiana Doctrina, istorum amentiam multis salibus prior elusisset - ele pergunta neste livro, de fato, aonde se chegaria se esse erro se tornasse uma opinião difundida - Quo, inquit, error iste demum evasisset, si semet animos hominum occupasset? - pois ninguém se curvaria ao ensino dos mais preparados, ninguém escutaria mais qualquer sermão - Nemo à scientiori se doceri passus fuisset. Nullus ad Ecclesiasticam concionem properasset - ninguém mais daria atenção à leitura do Evangelho -nec quisquam Evangelium pronuntianti praebuisset aurem

\footnotetext{
${ }^{375}$ Erasmo da Rotterdam, Antibarbari, op. cit, p. 219.

${ }^{376}$ Desiderii Erasmi, LB, X, op. cit., 1740 A a C.
} 
- pois tudo isto seria supérfluo se se pensasse que seria apenas necessário que se esperasse do céu a erudição - Haec enim otiosa fuerat futura si coelitus eruditionem exspectandam putassent $t^{377}$. Erasmo arremata o argumento, perguntando posteriormente, por que razão os Apóstolos teriam escrito ou os evangelistas, Jerônimo ou Agostinho - alioqui cur ipsi scripsere Apostoli? Cur evangelistae an Hieronymus? An Agostinus? - e afinal, por que os outros autores cristãos também nos teriam deixado seus escritos como testemunho de seu talento? - Cur caeteri nobis ingenii sui monumenta reliquerunt? ${ }^{378}$

O argumento de ordem psicológica: Erasmo explora no limite do hilário as conseqüências paradoxais, esdrúxulas, todas inaceitáveis e derivadas, no nível psicológico, da opinião favorável à inspiração da ciência divina ou profana. Adverte provocativamente já de início, que no caso de uma real inspiração divina deveríamos apenas ordenar ${ }^{379}$ se desejamos recebê-la toda de uma vez ou se preferimos que o Espírito Santo nos venha em socorro a cada vez que nos seja necessário - Sed statuamus oportet, utrum semel nobis omnia infudi jubeamus, an quoties usus erit, toties praesto Spiritum fieri malimus - mas recomendando que se prefira esta segunda solução por lhe parecer muito mais cômoda - Equidem posterius hoc longe commodius esse censeo - pois se a inspiração viesse toda de uma vez, deveríamos sempre sofrer o cansaço de recordá-la - nam si semel infundat, noster erit labor meminisset - e para não sobrecarregar a memória é melhor dar carta branca ao Espírito Santo - Quare ut memoriam ea sarcina levemus, satius erit coelesti Spiritui omnia permittere - desde que o importante é que continue a nos assistir chamado e invocado segundo a exigência da circunstância - ille modo praesto Fiat, vocatus et invocatus ut res postulat - a fim que nos sugira somente o suficiente para o momento e nada além disto - Quantum satis non amplius suggerat. Se devemos escrever um livro, levante vôo o espírito e nos dirija a mão enquanto nós permanecemos despreocupados scribendus erit liber, advolet, et nobis securis calamum regat. Há um discurso para ser feito: então ele pode posar ao lado do nosso ouvido em forma de pomba e regular nossa

\footnotetext{
377 Idem, 1740 D a E.

${ }^{378}$ Idem, 1742 A.

379 Traduzindo “jubeamus” por “ordenar”, fica preservada a idéia de que a noção de inspiração divina de conhecimentos instrumentaliza a divindade. Na tradução italiana, Luca D’Ascia, em op. cit., p. 219, preferiu "decidere": "solo dobiamo decidere se desideriamo ricevere (...)" arrefecendo o efeito ridículo da frase original.
} 
língua - Habenda erit oratio, tum vero in columba figura ad aurem assideat, linguam ipse temperet - nós nos limitaremos a abrir a boca para poder cantar com o rei Davi, autor do salmo "Abri a boca e fiz vir o Espírito" - nos modo hiscere meminerimus, ut cum psalmographo Rege canere liceat “Os meum aperui, et attraxi Spiritum”380. Mais à frente, Erasmo joga luz em mais uma noção obscura e cheia de reminiscências pagãs e aceita acriticamente pelo senso comum sem a ponderação sobre suas conseqüências teóricas: dizse que Pedro, Tiago e João falaram e escreveram seguindo a inspiração do Espírito Santo Sed hic mihi illud objicies quod Spiritu Sancto instructi, locuti sunt Dei homines - mas é necessário saber de que maneira falaram inspirados. Erasmo aumenta o tom provocativo e pergunta como deve ser entendida afinal esta fala do Espírito Santo - Quonam modo igtur tu eos locutos fuisse arbitraris? - se foi talvez à maneira dos sacerdotes pagãos ou da profetisa de Apolo, colhida por um tipo de invasão espiritual, que não entendiam o que diziam - Num vaticinantium Phoebadumve more, ut furore quodam correpti ipsi quid dixerint non intelligerent? ${ }^{381}$.

O argumento da imoralidade: uma taxativa e não usual condenação moral da comumente aceita idéia da ciência obtida por inspiração divina é colocada de maneira discreta em meio a outras idéias na seguinte fórmula inclemente: a ciência é algo excelente se obtida pelo estudo, mas ociosa se devemos esperá-la dormindo passivamente sem agir, que ela nos venha por inspiração durante o sono - praeclara, si studio comparanda est sapientia, otiosa, si per somnum otiosis exspectanda ${ }^{382}$ - resta, no entanto, julgar se além da condenação moral, o adjetivo “otiosa” também remete à intuição de que o conhecimento de uma ciência que, pertença a uma outra ordem de razões ou natureza não humana, encontra-se na impossibilidade de ser comunicada a outros humanos, como será exposto avante na discussão do argumento lógico. Também mais à frente, tomando do próprio senso comum argumentos contra a idéia geralmente aceita de que há uma inspiração divina, o autor admite que se leia que muitos estudiosos que aspiravam à sabedoria a conseguiram de forma sobrenatural - Et ex studiosis multos eruditos evasisse, adjutore hoc spiritu legimus - mas acrescenta a pergunta inesperada sobre se alguém ouviu ou leu que um asno tenha se

\footnotetext{
${ }^{380}$ Desiderii Erasmi, LB, X, op. cit., 1740 de C a D.

${ }^{381}$ Idem, $1741 \mathrm{C}$.

${ }^{382}$ Idem, 1742 A.
} 
tornado de repente teólogo - at ex asino theologum repente factum quis unquam aut audivit aut legit?. Observe-se que Erasmo não afirma que houve qualquer evento sobrenatural, apenas que aceita que esteja escrito: presentando sua posição pessoal a respeito do assunto, confessa que lhe impressionam pouco as narrativas que circulam dizendo que uma pomba apareceu ao lado do ouvido de um homem santo enquanto este falava ou escrevia - Nec quicquam his exemplis moveor, quae vulgo narrant, alii columbam ad aurem dicentis scribentisve conspectam - ou que um livro foi revelado ao seu autor enquanto este dormia alii per somnium librum traditum; na sua avaliação, esvaziando diplomaticamente a importância destes casos, quer se tratem de invenções dos admiradores para aumentar o prestígio de algum homem de fé - Sint ista sane vel conciliandae auctoritatis gratia à benevolis conficta - ou se tratem mesmo de verdade como alguns insistem, o autor não faz disto uma questão de vida ou morte - Sint vel Vera, si quis pugnet, equidem haud pugno ${ }^{383}$.

O argumento da ignorância: os bárbaros não estão preparados para perceber como a erudição dos homens de Igreja se baseia na erudição dos profanos e Erasmo, pelas poucas linhas que dedica a este argumento, parece chegar ao limite do que pode ser explicado para um imenso público que apenas começava a ter acesso a uma pequeníssima parte do tesouro de Minerva acumulado pelos antigos e que, sem qualquer ponto de referência, sofria uma ilusão de perspectiva que não lhe permitia restringir o campo de originalidade do cristianismo apenas ao que lhe é devido, não notava lateralmente a sua dependência das invenções pagãs - Ethnicis inventione - e se permitia afirmar por ignorância que a erudição dos homens de Igreja não se baseia nos autores pagãos. Para este público, Erasmo responde de maneira lacônica, compreendendo a impossibilidade de convencer, dizendo simplesmente que este pensa assim, pois não tem olhos para ver - Quod si in his Ethnicas fuisset negabis, ego oculos esse tibi negavero - ajuntando apenas que se alguém replicasse, como sempre, que os Apóstolos receberam a sabedoria teológica por inspiração enquanto estavam rezando e, diferentemente, conquistaram o saber profano com as próprias forças - Sin divinam scientiam illis orantibus infusam esse, humanam vero sibi peperisse dixeris - ele, Erasmo, riria novamente desta distinção e lhe faria uma segunda reprimenda - ridebo commentum, et te vicissim criminabor - por irromper agora no campo

\footnotetext{
${ }^{383}$ Idem, 1742, C e D.
} 
da teologia sem ter se preparado, deixando tolamente de lado as letras humanas e a erudição pagã e ignorando o exemplo de tantos grandes homens - contra tantorum exempla virorum praeteritis humanis litteris ad divinam scientiam tam stolide irrumpas ${ }^{384}$. Mas em passagem anterior Erasmo já havia se levantado contra aqueles que, se apresentando como entendidos nas coisas humanas - at vix crediderim ullos esse tam omnis humanae rationis expertes - acham que podem separar o cristianismo de toda a literatura antiga de modo que haja uma erudição puramente cristã - ut universam litteraturam à Religione segregandam putent, modo fit Christiana - e sentenciara duramente nesta ocasião, sempre através do personagem Batt: “Como se houvesse uma erudição propriamente cristã que não fosse um nada!” - Quasi vero, inquit Battus, ulla fit Christiana quae non eadem fit ineruditissima mas faz a ressalva de que não trata dos dogmas cristãos, mas das disciplinas inventadas pelo Homem - loquor autem non de mysteriis nostrae Religionis, sed de disciplinis repertis - pois, pergunta, se quisermos confessar, depois dos pagãos - Si vera fateri velimus, post Ethnicos - o que, de novo, os cristãos inventaram que não seja bárbaro? - Quid enim illos novi à nobis repertum, quod non idem fit indoctum? E, en passant, utilizando as tão latinas antíteses romanas, mostra sua independência crítica disparando: o que tão bem inventamos que não tão mal tenhamos sabido preservar do que foi inventado por outros? - Quid autem inveniamus bene, qui aliorum inventa tam male tuemur? ${ }^{385}$. A seguir, o autor é ainda mais claro afirmando que para si não há outra erudição que não seja secular e à qual, de fato, chamam de antiga - Ego igitur nullam esse eruditionem puto, nisi quae fit secularis (sic enim appellant antiquam) - ou pelo menos nutrida pelas disciplinas pagãs - aut certe seculari litteratura condita et instructa - que poderá tranqüilamente chamar de "cristã" para que não se pense que a ciência pagã é por si mesma um mal - eam ( si perversa et impia absit opinio) Christianam etiam patiar appellari ${ }^{386}$.

O argumento do paganismo da idéia de inspiração divina: a crítica erasmiana extrai conseqüências insuspeitas da aceitação fácil de que há um conhecimento divino interdito à inteligência humana como foi fixado popularmente pela imagem de Paulo

\footnotetext{
${ }^{384}$ Idem, 1743 D.

${ }^{385}$ Neste trecho preferi não seguir Luca D`Ascia em Erasmo da Rotterdam, Antibarbari, op. cit., p. 140, que propõe a seguinte facilitação: "De outro modo, como podemos enriquecer um corpo de doutrina que não somos nem ao menos capazes de conservar?”.

${ }^{386}$ Desiderii Erasmi, LB, X, op. cit., 1713 F.
} 
no terceiro céu ouvindo o que é sacrílego trair, contando para os Homens - in paradisum (...) audituri quae nefas fit hominem homini prodere. Da posição segura de quem parece fazer uma crítica moral àqueles que querem manipular a divindade em proveito próprio atribuindo a ela a responsabilidade de obter-lhes a erudição, Erasmo permite-se reduzir a importância da famosa narrativa do milagre do rapto de Paulo, que aliás não é confirmada nem pelo próprio Apóstolo ${ }^{387}$, e sobretudo, fazer uma dupla provocação aos teólogos ao jogar luz sobre o fato de que, se os conhecimentos divinos são conhecidos apenas pela divindade e alcançáveis pelos mortais apenas se comunicados graciosamente por ela, então estes conhecimentos divinos são negados à quase totalidade dos cristãos, que poderiam recebê-los, mas ao invés disto são mantidos na ignorância pela divindade, e não podem ser apreendidos pelos mortais sem que sejam violados e se cometa algum sacrilégio; i. e., o conhecimento divino é mal distribuído ou é usurpado. Todo este quadro crítico, que resvala à irreligião ao ridicularizar a crendice popular, é sintetizado pela irônica advertência "a menos que prefiramos esperar, como Paulo, sermos raptados misticamente para o paraíso ou para o terceiro céu - nisi malumus exspectare, dum Pauli more vel in paradisum, vel in tertium usque coelum rapiamur - para ouvirmos mistérios demasiado sublimes para, sem sacrilégio, serem comunicados entre os homens - audituri quae nefas fit hominem homini prodere” ${ }^{388}$ - e ficam evidenciadas as semelhanças entre esta proposição e a religião greco-romana, plena de deuses caprichosos, ciumentos de suas prerrogativas, indiferentes ao destino dos Homens ${ }^{389}$ e rápidos em punir qualquer tentativa de ascensão ao Olimpo ou de roubo de seus segredos.

\footnotetext{
${ }^{387}$ Epistula II Sancti Pauli Apostoli Corinthios, Nova Vulgata - Bibliorum Sacrorum Editio, op. cit., p. 1727: "É natural envaidecer-se, mas não fazendo acreditar que mereceu ter visões e revelações do Senhor. Conheço um homem em Cristo com menos de quarenta anos que - com seu próprio corpo ou sem ele, não sei, conheceu a Deus - levado em rapto até o terceiro céu. E conheço um homem que - com seu próprio corpo ou sem ele, não sei, conheceu a Deus - pois foi levado por um rapto até o paraíso onde ouviu palavras divinas misteriosas que não são permitidas ao homem falar" - "Gloriari oportet; non expedit quidem, veniam autem ad visiones et revelationes Domini. Scio hominem in Christo ante anos quattuordecim - sive in corpore nescio, sive extra corpus nescio, Deus scit - raptum eiusmodi usque ad tertium caelum. Et scio huiusmodi hominem - sive in corpore sive extra corpus nescio, Deus scit - quoniam raptus est in paradisum et audivit arcana verba, quae non licet homini loqui”.

388 Desiderii Erasmi, LB, X, op. cit., 1740 C.

389 Lucrèce, De la Nature - présentation, traduction, et notes par Charles Guittard, Paris, Imprimerie nationale, 2000, p. 414.
} 
O argumento lógico: Erasmo depois de mostrar que o pensamento favorável à inspiração divina contém um paganismo incontornável, revela a grave questão epistemológica de fundo implícita na separação que o senso comum e os teólogos ignorantes ou mal intencionados fazem entre ciência profana e divina. De fato, se o engenho dedicado à invenção e estudo das disciplinas compõem uma ciência humana que por mais que progrida pertencerá e permanecerá sempre restrita a uma ordem de razões próprias do Homem, i. e., a uma natureza diferente daquela do conhecimento divino que supostamente possuiria uma ordem própria de razões totalmente desconhecida pelo Homem, então isto significaria, em todas as suas conseqüências lógicas, que não há uma comunicação possível, ao menos intelectual, entre o homem e a divindade, pois se há uma ciência divina que o Homem não possa alcançar por seu próprio esforço porque esta integraria uma ordem de razões que lhe são alheias ou interditas, então esta ciência também não lhe pode ser explicada ou inspirada - Coelesti munere (...) consequuti ${ }^{390}$ - talvez porque o homem não conheceria a ordem de razões de que deriva e então ela é definitivamente incomunicável para o Homem.

Como conseqüência, se é aceito que esta hipotética ciência divina foi infundida aos Apóstolos por milagre - divina, quam apostolos accepisse constat ${ }^{391}$ então esta teria sido inútil para a comunicação entre os homens, pois inalcançável e intransferível por natureza a não ser que ocorra um milagre para cada transferência. Este problema lógico será talvez o motivo de Erasmo perguntar o que querem afinal dizer estes que afirmam que o Espírito Santo inspirou-lhes - Istis enim, inquiunt coelestis Spiritus ministravit. (...) Quid enim ista tandem oratione sibi volunt? - e afirmar que muito se admira que estes monstros da sutileza dialética, que se vêem como homens tão extremamente agudos - Equidem admirari soleo in hominibus qui sibi perquam acuti videntur - argumentem tão estupidamente a favor da inspiração do conhecimento divino dos Apóstolos -quippe Dialectici tam hebes ingenium, nisi forte perperam ista faciunt ${ }^{392}$. Até na última coluna do seu Antibárbaros, Erasmo insistirá na desrazão dos que postulam e reivindicam a existência de uma ciência divina inspirada e de natureza diferente e superior à humana chegando a

\footnotetext{
${ }^{390}$ Desiderii Erasmi, LB, X, op. cit., 1740 A.

${ }^{391}$ Idem, 1740 A.

${ }^{392}$ Idem, 1740 B.
} 
afirmar que basta de discutir sobre este assunto pueril - Sed in re puerili plus satis est disputandum - pois estes que costumam nos contrapor esta ciência divina para recusar a necessidade de que todos estudem - nam qui istam divinam scientiam nobis solent objicere - estão tão longe da ciência humana quanto da própria ciência divina - adeo tum $a b$ humana, tum à divina absunt - ao ponto de, como recomenda Hipócrates, deverem ser antes amarrados com correntes do que aceitos em um debate racional - ut Hippocraticis potius vinculis sint alligandis, quam rationibus coarguendi ${ }^{393}$.

Em resumo deste importante argumento, parece que para o autor há apenas dois caminhos: ou há uma ciência divina inalcançável pelo esforço e ciência humana e então, se esta é inspirada por milagre em um fiel este não pode comunicá-la intelectualmente para os demais, pois é normalmente inalcançável à compreensão e, por conseguinte, a sua comunicação de um homem para outro exigiria um outro milagre; ou há apenas um conhecimento, uma única e grande cadeia de razões que o Homem, na extremidade inicial e inferior desta cadeia, vai descobrindo através do persistente esforço que envolve a invenção apoiada pela sua razão natural, ambas cultivadas pelo estudo das disciplinas - e ascendendo lentamente para a verdade única e divina, a parte final e mais alta desta cadeia de razões, da qual revelações podem ser feitas, digamos, antecipadas, para o Homem através de inspirações divinas que, por integrarem, portanto a mesma ordem de razões familiar aos homens, podem ser compreendidas por estes ao preencherem a lacuna das razões que separaram as duas e verificarem que as razões humanas corretas são desdobramentos das divinas ou conduzem a elas. Note-se que mesmo neste argumento a inspiração divina não é aceita e afirmada pelo autor, mas apenas tratada como hipótese que deve ser analisada logicamente.

\footnotetext{
${ }^{393}$ Idem, 1744 A. Luca D’Ascia em Erasmo da Rotterdam, Antibarbari, p. 230, traduz o início desta frase diferentemente: "Ma fin troppo tempo abbiamo dedicato a difendere tesi del tutto ovvie. I nostri avversari, che si oppongono a noi "poeti" in nome della loro cara teologia, non sanno proprio dove stanno di casa sia la teologia, siai la scienza profana (...)” que traduzo empregando uma longa perífrase para melhor esclarecêla : “(..) basta de discutir sobre este assunto pueril pois estes, que costumam nos contrapor esta ciência divina para recusar a necessidade de que todos estudem, estão tão longe da ciência humana quanto da ciência divina”. Em resumo, no original há a oposição entre ciência "humana e “divina” e o tradutor preferiu "scienza profana" e "teologia”, opção que não acompanho pois o autor parece preocupar-se antes com a possibilidade de um conhecimento divino proibido aos Homens que com uma ciência teológica que nem os próprios teólogos reivindicam como totalmente revelada. Deve ficar claro que para Erasmo a teologia é uma ciência tão humana quanto a profana, e que aqui ele se posiciona contra uma teologia divina segredada a alguns homens apenas.
} 
$\mathrm{O}$ argumento das pistas e a unidade fundamental entre o saber humano e o divino: repetindo que Agostinho, mesmo velho e sábio, nunca se arrependera de haver estudado as disciplinas pagãs, Erasmo subitamente realça uma importante idéia filosófica agostiniana lembrando que este admitia mesmo tê-las estudado intencionalmente servindose da erudição pagã como de pistas ${ }^{394}$ para alcançar gradualmente, passo a passo, a cognição da verdade suprema - autem consulto etiam a se factum fatetur, ut his tanquam vestigiis ad Summae Veritatis cognitionem gradatim accederet - pois para Agostinho o saber profano é como uma centelha que escapa da luz imortal de Deus - Has enim disciplinas scintillas quasdam ait esse ab immortali illa luce promicantes - e que indica como chegar à fonte - quarum indicio ad fontem illum perveniatur. Apoiando-se na autoridade do Bispo de Hipona, Erasmo critica veladamente os teólogos, tanto aqueles que, por uma piedade supersticiosa ou aqueles escolásticos aristotélicos - vide averroístas - que são favoráveis à separação do saber divino do profano e aponta a diferença entre a precipitação de ambos os tipos e a escrupulosa atitude de Agostinho; os critica também por quererem, bruscamente e sem uma preparação interior - Et quanto religiosius ille quam nos, qui animis rudibus - não entrar, mas irromper entre os mais reservados segredos divinos - repente ad divinitatis arcana non ingredimur, sed irrupimus - os acusa de quererem não escalar, mas de voar em direção ao Olimpo - non adscendimus, sed involamus - e, como os titãs, de sobreporem massa sobre massa para ocuparem a montanha celeste contra a vontade de Júpiter - et tanquam gigantes, exstructis in coelum molibus, invito Jove arcem illius occupare conamur - por isto Agostinho que andava passo depois de passo pôde entrar - eoque ille quia gradatim adscendit receptus est - enquanto nós, que imitamos estes teólogos, somos expulsos, jogados para baixo e precipitados no abismo nos repellimur, dejicimur, praecipitamur ${ }^{395}$.

O argumento de que o Espírito Santo não inspirou o saber profano, mas a necessidade de assimilá-lo: este é outro torneio erasmiano que diminui a aparente desvantagem e desprestígio das ciências profanas - se aceita a hipótese de que estas não foram inspiradas nos Apóstolos - ao reivindicar que foi certamente inspirada aos Apóstolos e a todos pelo menos a necessidade de assimilá-las. Erasmo faz o personagem cônsul

\footnotetext{
${ }^{394}$ D’ Ascia, Luca; prefere traduzir “vestigiis” por “via” em op. cit., p. 215.

${ }^{395}$ Desiderii Erasmi, LB, X, op. cit., 1738 E a F.
} 
assumir esta hipótese da não inspiração, mas ainda de maneira tacanha, dependente do intervencionismo divino e, como se buscasse uma consolação reproduzindo uma atitude verossímil do público em geral, perguntar se o Espírito Santo, por não ter infundido então em nenhum dos Apóstolos a ciência profana, que é o verdadeiro assunto da presente discussão - nulli Apostolorum Spiritus coelestis profanas litteras infudit, de quibus hic erat instituta disputatio - nenhuma noção de dialética, retórica e poesia, se este Espírito seria então impedido de provê-lo se julgasse que poderia servir - non Dialecticen, non Rhetoricen, non Poesim, infusurus haud dubie, sicubi haec usui futura fuissent.

Parece que Erasmo, depois de combater duramente a crença arraigada em uma ciência divina privativa da divindade e à qual alguns homens inspirados teriam acesso em circunstâncias sobrenaturais, quer na seqüência enfrentaar mais brandamente o pensamento favorável às explicações milagrosas da origem da ciência profana junto aos santos homens, e insistir por exclusão na sua origem humana, ao responder à pergunta do cônsul pela primeira vez afirmativamente, concordando que o Espírito Santo não inspirou ninguém - Nemini infudit, inquit - mas concedendo ao senso comum e ao pensamento religioso vulgar, sempre dependente das imagens maravilhosas, já frustrado pelo encolhimento racional do campo de intervenção sobrenatural da divindade e decepcionado inconfessadamente com o aumento de sua responsabilidade intelectual, ao acrescentar à sua resposta que concorda que o Espírito não é impedido de fazê-lo: - donemus istud - algumas letras que não comprometeriam nem mesmo um cético ao preservar íntegro o campo do possível.

E para aqueles que são incapazes de acompanhar o debate ou não querem se demorar sobre o assunto, Erasmo, buscando sempre ampliar seu público, relativiza enfim a questão perguntando o que importa, de qualquer maneira, se o Espírito infundiu o saber profano ou não - quanquam quid refert, an infuderit Ethnicas litteras? - guardando todo o relevo para a percepção de que, na realidade do dia a dia, neste mundo como se apresenta, na condição humana presente, as ciências pagãs, as letras humanas são afinal imprescindíveis. Talvez seja isto que signifique a maneira como o autor completa esta pergunta postulando enigmaticamente que o Espírito Santo infundiu, com certeza nos 
Apóstolos e em todos, aquelas exigências que impõem o dever de assimilá-las - id certe infudit, cujus gratia Ethnicae litterae sunt discendae - e exemplificando com a imagem dos gramáticos pois, se fosse possível adquirir a competência ativa e passiva de uma língua sem estudá-la - Si datum esset quavis Lingua et integre loqui, et loquentes intelligere - estes não teriam motivo para torturar seus pobres estudantes - nihil esset causae, cur Grammatici miseros adolescentes excarnificarent ${ }^{396}$.

O argumento cético da dúvida como atual condição humana: na seqüência do exemplo do gramático que exige esforços dos seus alunos adolescentes, Erasmo dá um passo adiante e conclui que se nenhuma nuvem impedisse a verdade de ser evidente à mente mortal - Si is esset mortalium animus, qui nulla nube praepeditus - tanto para ver por si próprio quanto para mostrar aos outros - facile statim verum et videret, et ostenderet $^{397}$ - em vão exercitaríamos os raciocínios complexos e as sutilezas lógicas frustra et ratiocinatione, et dialecticis argutiis exerceremur ${ }^{398}$. Parece que, definitivamente, já na última coluna de seu Antibárbaros, Erasmo apresenta sua visão particular do entendimento humano apontando sem ilusões para uma humanidade mergulhada em dúvidas para cujas soluções não há uma resposta única, indiscutível, inquestionável sem qualquer mancha de dúvida - nulla nube - pois, a necessidade das disciplinas pagãs, como testemunham as obras dos doutos cristãos - é a prova desta atual condição humana de dúvida. Ressalte-se que o ceticismo da afirmação erasmiana não se deixa prender na limitação do ceticismo acadêmico já difuso na sua época pois não faz a afirmação de que as

\footnotetext{
396 Idem, 1743 E.

${ }^{397}$ Erasmo da Rotterdam, Antibarbari, op. cit., p. 231. Na tradução italiana de "Si is esset mortalium animus, qui nulla nube praepeditus, facile statim verum et videret, et ostenderet (...)” é proposto: “(...) Se la verità fosse evidente alle menti umane, senza alcuna nebbia d'errore(...) “ com o que a passagem é abreviada com algum prejuízo para a questão epistemológica pois não é traduzida a frase “(...)et ostenderet(...)” que recuperada poderia ser traduzida por "Se a verdade fosse evidente à mente humana sem qualquer névoa de erro, tanto para ver por si próprio quanto para mostrar aos outros” com a qual, nos parece, Erasmo se refere à importante dificuldade lógica, fatal para a retórica, que foi apontada no argumento lógico, que nega que uma ciência divina que fosse inspirada e não pudesse ser alcançada com o esforço intelectual humano, por ser um conhecimento de natureza diversa, poderia em seguida ser explicado para os outros homens por quem a recebeu; i. e., quem recebesse o conhecimento divino - verum et videret - não poderia explicá-lo, mostrá-lo aos outros - et ostenderet.

398 Desiderii Erasmi, LB, X, op. cit., 1744 A. Testemunho de que os humanistas não recusam o estudo da dialética que serve imensamente à retórica, que ainda recebe os serviços de outra artes, tais como a eloqüência, mas a sua utilização como recurso único pela teologia.
} 
dúvidas são em si insuperáveis e que é impossível alcançar a verdade em si ${ }^{399}$, mas afirma a condição humana atual de dúvida com uma frase condicional começada por "Si" que fundamenta esta condição não em qualquer instância transcendental imutável mas na impossibilidade lógica de uma inspiração divina de conhecimentos impossíveis para o Homem e no simples fato verificável no mundo visível de que aparentemente, no estado presente, precisamos dos studia humanitatis.

O argumento platônico da continuidade entre a razão humana e a divina: o último pensamento de grande relevo que coroa a seqüência final de argumentos deste livro em que o humanista quer consolidar a unidade entre fé e razão, com recursos que hoje se separa equivocadamente entre filosofia e retórica, e definitivamente provar prática e teoricamente e convencer, indo além dos renascentistas italianos do século XIV e do XV, não só a propósito da utilidade, mas especialmente da necessidade inelutável para a religião, do objeto de estudos de toda a sua vida, as disciplinas pagãs, as letras humanas; este último pensamento, dizia, é expresso em uma fórmula suave para os ouvidos religiosos simples, angustiados pelo contínuo convencimento de que diminui o número de milagres a sua volta. Propondo que a cadeia de razões construída pelas invenções humanas, mesmo menor e precária, integra a mesma cadeia das superiores razões divinas, Erasmo assegura reconfortantemente que precisamos das disciplinas pagãs - disciplinis liberalibus opus est para chegarmos através de um percurso lento e tortuoso aonde o Espírito Santo conduziu os Apóstolos por uma via curta - ut vel longis ambagibus eo tandem perveniamus, quo Spiritus Apostolos compendio perduxi. E, generosamente, pois não é apenas filósofo, concede, com uma bondade não livre de um último granum salis: Pedro não quis nossas letras... mas estas ajudaram a Paulo - Non desideravit Petrus nostras litteras, Paulum tamen adjuverunt ${ }^{400}$.

\footnotetext{
${ }^{399}$ Não encontrei ainda evidências de que Erasmo conheceu como Pico della Mirandola os argumentos do Pirronismo através da obra de Sexto Empírico; mas Jean-Paul Gillet na p. 121 de sua tradução de Língua indica em nota de rodapé que uma passagem narra uma anedota tirada de Sexto Empírico em Adversos Mathematicus ou de Cícero: "Depois que foi perguntado a Cleonte, qual a diferença havia entre a dialética e a retórica, ele mostra seu punho, depois apresentou a mesma mão, aberta".

${ }^{400}$ Desiderii Erasmi, LB, X, op. cit., 1744 A.
} 


\section{CONCLUSÃO}

A compreensão, nos dias de hoje, da resposta erasmiana ao anseio de toda inteligência na Renascença em conciliar a verdade da Revelação, da Bíblia, do cristianismo à verdade da erudição clássica, das disciplinas profanas, da sabedoria antiga, esclarecendo como era exatamente possível a unidade da verdade entre estas - que quase todos humanistas desde Petrarca intuíam, mas não explicavam, especialmente depois que os escolásticos desesperaram de tentar fundar a fé na razão frente aos argumentos averroístas e ockhamistas - exige do estudioso do Renascimento a restauração preliminar da unidade de significado entre filosofia e retórica, a recuperação de um primordial sentido único que, nascendo entre os gregos, se desdobra como tradição latina e sobrevive na Europa do Medievo até voltar a florescer com a incorporação do patrimônio de textos retóricos preservados por árabes e gregos bizantinos.

Sim, porque nos dias tecnicistas de hoje, parece perdida esta tradicional identidade entre filosofia e retórica; separação que é transposta para o Renascimento, no qual comentadores e o senso comum - como faziam os próprios escolásticos - identificam sem sobras a filosofia apenas à metafísica, que é a longa tradição do pensamento grego que voltou sua reflexão para os problemas do Ser e do próprio pensamento. Ao reduzirem o significado da filosofia à metafísica, criam para si mesmos dificuldades e embaraços para tratar do humanismo, oscilam e titubeiam em reconhecer neste movimento cultural a continuidade da filosofia enquanto retórica, que é a tradição de reflexão sobre os problemas fundamentais do Homem.

Por isto, Erasmo não pode ser corretamente compreendido como defensor da retórica no século XVI em um suposto conflito na Renascença entre a filosofia e a arte de Cícero, visto como concorrência entre diferentes métodos para a obtenção da verdade e sua exposição. Não há historicamente esta disputa com estes nomes, o que há é o lento esgotamento de possibilidades, no século XIII, de emprego da dialética pela teologia para fundamentar a fé na metafísica criada pelos gregos, o que ficou claro primeiramente no sucesso e expansão do averroísmo no Ocidente e foi explicitado pelos argumentos 
definitivos do empirismo ockhamista no século XIV. Neste quadro de rupturas, Erasmo integra uma corrente de pensamento que, a partir de Petrarca, vem completar em outro plano esta crítica ao abuso da dialética, devolvendo-a à sua função propedêutica à retórica, como já haviam defendido Cícero, Sêneca - que riam dos velhos que se divertiam com silogismos - e propor o retorno à tradição retórica dos Padres da Igreja.

Para Erasmo, a filosofia é retórica e não dialética, e o fracasso da dialética a serviço da teologia não significa o fracasso da razão para o conhecimento da verdade, seja esta humana ou divina. Certamente, para o autor, a razão pode levar ao conhecimento dos assuntos divinos e pode justificar a fé, mas não através do abuso dos conceitos e categorias resultantes da reflexão sobre o Ser como entes, obtidos de deliberadas hipóstases e reificações. Parece que em Erasmo há a recuperação do sentido socrático do amor à sabedoria - sophia - que exige uma necessária matização de seu decantado e propalado platonismo: o conhecimento de si e do Sumo Bem através do desvelamento e superação da ignorância pelo jogo dialético da razão sempre em busca do argumento mais forte, deve ser emancipado do estudo da natureza - physis - do que é, do Ser e das condições de seu conhecimento, pensamento que se volta sobre si mesmo sob o nome de metafísica e não demora em ambicionar ou ver lhe oferecerem o título de teologia. A busca do conhecimento de si pelo homem, que inclue o conhecimento sobre seus deuses, sua origem, felicidade, e fim, prevenida contra a tentação metafísica, pode continuar sempre em busca do melhor argumento em um avanço constante até a verdade.

Ora, todos os homens e todas as religiões podem reivindicar para si a posse do argumento mais forte no conhecimento do homem e de Deus e é justo que uma entre outras religiões acredite possuí-lo e poder com este unificar em uma verdade única as verdades parciais legitimamente alcançadas por outros. Erasmo, com a lucidez que não tiveram talvez nem os Padres da Igreja, muito menos Petrarca, percebe e compreende que a unidade da verdade sobre o Homem, que por definição é apenas uma, só pode ser alcançada por uma lenta e socrática unificação da verdade que entre os homens não saberia passar sem a arte do debate e do convencimento que é a retórica. Erasmo compreende que é a retórica que oferece com sua capacidade de invenção - inventio - o argumento superior 
capaz de sobrepor-se aos demais e que é a retórica que deve ser servida pela dialética no que esta oferece de garantias e facilidades para o discurso racional, pois esta sozinha é incapaz de inventar o argumento de que a unificação da verdade exige na arena onde se confrontam as inventiones de todos os homens em busca da verdade sobre si e seus deuses.

O autor se esforça por explicar de todas as maneiras que este conhecimento não pode ser deduzido à priori por autoridades dialéticas, que não há um conhecimento seguro de Deus e dos homens que se possa obter apenas com a especulação lógica e ainda menos podem ser confirmados os casos alegados de inspiração divina. O que resta ao Homem então é arrancado da única fonte ao seu alcance: sua faculdade de invenção. Desta esperança, pois também não é garantia de qualquer verdade, advém a famosa onivoracidade de Erasmo, interessado em obter um conhecimento enciclopédico de todas as invenções humanas disponíveis e daquelas ainda restauráveis.

Contra o argumento purista de que diferentes céus e épocas criaram imagens, visões, narrações - reunidas pejorativamenente, quando se trata de criações dos outros, sob os nomes de mitos e superstições ou mesmo aberrações - todas invenções freqüentemente contraditórias entre si, exclusivas e no limite inconciliáveis, Erasmo apontou várias vezes que a própria Bíblia apresenta dificuldades, armadilhas e enigmas que não impediram uma unidade de doutrina. E contra o terrível argumento da autoridade da Revelação cristã que deve bastar para todos os seus fiéis, Erasmo assume a posição conciliatória de que o cristão deve confiar na verdade de que se julga portador, pois realmente esta verdade é o argumento mais forte que unifica em uma verdade apenas tudo o que os pagãos - ethnicis - conseguiram alcançar com o longo esforço de sua invenção acreditando alcançarem a verdade definitiva.

Mas provocativamente, acrescenta que esta confiança mesmo na posse do melhor argumento deve ser razão e estímulo para que o cristão aceite descer à arena retórica sem medo de contaminar-se; a força de convencimento de seu argumento deve bastar-lhe e isto é válido inclusive para o confronto com os temíveis turcos de então para com quem se deve usar a pregação e o exemplo de vida. E corajosa e originalmente, avança 
deixando transparecer em todos os seus numerosos Colloquia e Adágia, Litterae, traduções e edições princeps, nos parece, que se as invenções pagãs não superam realmente a verdade cristã ex totum elas são utilíssimas e fortes suficientemente para se impor frente a algumas verdades cristãs secundárias, inessenciais, logo não necessariamente verdadeiras, que não pertencem à Revelação, mas são também invenções humanas da mesma natureza das invenções pagãs e por isso mesmo não devem ser poupadas do enfrentamento destas no campo da retórica.

Esta compreensão totalizadora é especialmente marcante da obra de Erasmo e conduz a uma distinção nítida: ao lado da verdade que os cristãos julgam ser sua Revelação e que realmente se impõe aos pagãos, juntaram-se invenções humanas com as quais o cristão não deve se comprometer com mais ardor do que usa para amar a própria verdade e, portanto, deve expô-las ao confronto retórico com as invenções pagãs. Desta distinção brotam seus argumento ácidos contra o ritualismo, a sacralização do que é puramente costume, supervalorização dos sacramentos, a crença nos santos e no poder das relíquias, em uma palavra, a superstição cristã, fonte de arbitrariedades eclesiásticas e estragos doutrinais com o conseqüente ofuscamento da própria Revelação.

Isto posto, temos um pensador cuja intensa frequentação do debate entre textos antigos o livra de uma identificação imediata e inocente com o platonismo ou o neoplatonismo de sua época e assim, na sua ação pública, parece inspirar-se tanto do personagem “Sócrates”, em sua versão não dogmática e questionadora que freqüentemente emerge nos diálogos de Platão, quanto do grande retórico Isócrates na sua crença no poder do logos em estabelecer o entendimento entre os homens, pois Erasmo é sobretudo o escritor que sempre acreditou na existência de uma verdade única e buscou o consenso entre os homens; mas é difícil na meia luz das possibilidades cambiantes, tocar a exata posição do autor: o mais cético dos diversos “Sócrates” que nos chegaram ainda absolutiza a teleologia do Sumo Bem e o mais confiante e pragmático Isócrates parece entregar todos os assuntos ao debate e à opinião, e já não sabemos então se os esforços de Erasmo apontam para uma verdade real que deve ser descoberta ou para uma que pode e deve ser inventada por todos nós. 
Quanto ao significado político de seus esforços em mostrar a unidade da verdade entre a sabedoria antiga e o cristianismo, também se pode perguntar se o mapa europeu redesenhado pelas guerras de religião, que se seguiram à radicalização do dogmatismo religioso frente à ruptura dos laços medievais entre fé e razão e o crescimento da crise cética no Renascimento, tornam menores os resultados do trabalho de Erasmo ou, ao contrário, os tornam heróicos na medida em que todas as suas energias intelectuais, empregadas incansavelmente, se não puderam evitar o cataclismo, certamente abrandaram seus efeitos pela enorme difusão e acolhimento de seu pensamento.

Para responder a esta pergunta demais ampla, considere-se modestamente, que o dogmatismo religioso pode ser resposta à dessacralização do mundo, à secularização crescente dos usos e costumes, à repentina e insuportável naturalização pagã do mundo das coisas - rerum - que seguia o florescimento econômico e a multiplicação dos fatos políticos, propiciadores, parece, de uma própria e característica visão de mundo, que a história quis que fosse perfeitamente complementada e coroada com a restauração da herança cultural clássica.

Neste quadro, é compreensível que importantes necessidades, que eram satisfeitas por uma velha visão de mundo, provocariam o colapso se não fossem atendidas por uma nova visão de mundo que a substituísse ou a esta se sobrepusesse sem uma, digamos, transferência de tarefas: as fundamentais questões do Homem às quais a religiosidade da velha visão de mundo respondia, deveriam agora ser respondidas pela nova visão de mundo que se impunha e trazia consigo a erudição pagã que, na realidade, também respondia a estas questões, mas que deveria ser explicada e divulgada com urgência.

Foi desta emergência que cuidou Erasmo, mas sem tornar-se conhecido por acreditar que os pagãos da Antiguidade pudessem ter todas as respostas para as questões fundamentais do Homem, inclusive porque seus contemporâneos adquirindo novas necessidades, não eram mais exatamente como os antigos greco-romanos e de fato Erasmo chegou mesmo a enfrentar purista italianos do classicismo acusando-os de “tentarem fazer o paganismo levantar a cabeça entre nós”. 
Assim, diante das crescentes tensões entre diferentes visões de mundo, Erasmo se propôs a febril e constante exposição da verdade que as unia e, com toda a agudeza de seu cálamo, mostrou como a sabedoria antiga poderia melhorar os costumes, amenizar a superstição, diminuir a violência e a injustiça e desmascar as imposturas de sua época, e como o cristianismo poderia apontar as inconfessadas e também renascentes idolatrias dos pagãos.

Mas podemos continuar perguntando se não foi então tarde que começou; se foi original o que disse; se não alcançaria mais leitores utilizando o vernáculo. E surgirá ainda aquele que insiste perguntando de novo se Erasmo afinal mostrou a unidade da verdade para a utilidade da Religião ou das Humaniores Litterae. Bem, repetindo a lição do mestre e meditando sobre a crescente necessidade de tolerância entre nós, poderíamos responder erasmianamente que, no Renascimento, a unidade da verdade significava, antes de tudo, a utilidade do Homem. 


\section{REFERÊNCIAS BIBLIOGRÁFICAS}

\section{Obras de Erasmo}

Desiderii Erasmi Roterodami; Opera Omnia, Hildesheim, Georg Olms, 2001. Esta edição da Opera Omnia de Erasmo é conhecida pela sigla LB tirada do nome latino Lugduni Batavorum do lugar de sua primeira impressão em Leiden, atual Holanda.

Desiderii Erasmi Roterodami; Opera Omnia - Recognita et adnotatione critica instrvcta notisque illvstrata - Ordinis Primi, Tomus Primvs, Antibarbari (introduction by Kazimierz Kumaniecki), Amsterdã, North-Holland Publishing Company Amsterdam, 1969. Esta edição de Opera Omnia de Erasmo ainda não foi concluída e é conhecida internacionalmente pela sigla ASD do nome latino Amstelodami da cidade onde se desenvolvem os trabalhos.

Érasme de Rotterdam; La Langue - Introduction, traduction et notations de Jean-Paul Gillet, Genève, Labor et Fides, 2002.

Érasme de Rotterdam; Éloge de la Folie - Traduction de Pierre de Nolhac, Paris, Garnier, Paris, 1954.

Érasme de Rotterdam; L 'essai sur le libre arbitre, Tradução de Pierre Mesnard em Érasme - La Philosophie Chrétienne, Paris, Vrin, 1970.

Érasme de Rotterdam; Le cicéronien (Dialogus ciceronianus) in Érasme - Éloge de la Folie, Adages, Colloques, Reflexions sur l'art, l'éducation, la religion, la guerre, la philosophie et correspondence - Édition établie par Claude Blum, André Godin, JeanClaude Margolin et Daniel Ménager, Paris, Robert Laffont, 1992.. Esta obra será citada em seguida como "Coletânea R. Laffont”.

Erasmo da Rotterdam; Antibarbari - a cura di Luca D’Ascia, Torino, Nino Aragno Editore, 2002.

\section{Outras fontes}

Bacon, Francis; Novum Organum, São Paulo, Ed. Abril, Col. Os Pensadores, 1973.

Cícero; De Inventione, Tradução de Henri Bornecque, Ed. Garnier Frères, Paris, 1954. 
Horace; Oeuvres complètes - Odes et Épodes, Tradução de François Richard, Paris, Garnier, $1^{\circ}$ tomo, 1950.

Lucrèce; De la Nature - présentation, traduction, et notes par Charles Guittard, Paris, Imprimerie nationale, 2000.

Lucrécio; De Rerum Natura, São Paulo, Abril S/A, Col. “Os Pensadores”, Tomo V, 1973.

Lutero, M.; De Servo Arbítrio in Obras de Martin Lutero - la voluntad determinada, Tradução espanhola de Erich Sexauer, Buenos Aires, Publicaciones El Escudo e Paidós, 1976.

Nicolau de Cusa; A douta ignorância, Tradução, Prefácio, Introdução e Notas do Prof. Dr. Reinholdo Aloysio Ullmann, Porto Alegre, Edipucrs, 2002.

Nova Vulgata - Bibliorum Sacrorum Editio, Città del Vaticano, Libreria Editrice Vaticana, Editio Typica Altera, 1998.

Sêneca; Sobre a Brevidade da Vida, São Paulo, Nova Alexandria, 1993.

\section{Bibliografia critica}

Burckhardt, Jacob; La Civilisation de la Renaissance en Italie - Essai Tradução de H. Schmitt, revista e corrigida por Robert Klein, Paris, Librairie Plon e Club du meilleur livre, 1958.

Carena, Carlo; introdução in Il Disprezzo Del Mondo - Erasmo da Rotterdam, Arnaldo Mondadori Editore S. p. A, 2000.

Cassirer, E., Kristeller, P. O e Randall Jr.; The Renaissance Philosophy of Man, Chicago, The University of Chicago, 1948.

Chomarat, Jacques; Érasme - Oeuvres Choisies, Paris, Librairie Générale Française, 1991.

Colombero, Carlo; Uomo e natura nella filosofia del Rinascimento, Torino, Loescher, 1985.

D’Ascia, Luca; prefácio L'ombra de Valla - La formazione “laica” de um genio religioso del Cinquecento in Erasmo da Rotterdam, Antibarbari, Torino, Nino Aragno Editore, 2002.

De Bujanda, J. M; introdução in Érasme de Rotterdam - Liberté er Unité dans l'Église, Quebec, Editions Cosmos, 1971. 
Dolan, John P.; The Essential Erasmus - selected and translated with introduction and commmentary, New York, Meridian Book, 1993.

Febvre, Lucièn; Au coeur religieux du XVIe siècle, Paris, Librairie Générale Française, 1983.

Gilson, Étienne; La Philosophie au Moyen Age - Des origines patristiques a la fin d XIV siècle, Paris, Payot, 1952.

Hadot, P.; "L’image de la Trinité dans l'âme chez Victorinus et chez saint Augustin”, Studia Patristica VI - Papers presented to the Third International Conference on Patristic Studies held at Christ Church, London, 1959, Berlin, Akademie, Parte IV, 1962.

Halkin, L. E.; Erasmo, México D. F., Tezontle, Fondo de Cultura Económica, 1992.

Huizinga, J.; Erasmo, Torino, Giulio Einaudi, 1941.

Jacopin, Paul, Lagrée, Jacqueline; Érasme Humanisme et Language - Collection "Philosophies”, Paris, PUF, 1996.

Jaeger, Werner; Paidéia - A formação do Homem grego, São Paulo, Martins Fontes / Universidade de Brasília, 1989.

Kristeller, Paul Oskar; El Pensamiento Renascentista y sus fuentes - Compilador Michael Mooney, tradução de Federico Patán López, Madrid, Fondo de Cultura Econômica, 1982.

Kumaniecki, Kazimierz, introdução ao Antibarbarorum Líber - Ordinis Primi, Tomus Primvs, in Desiderii Erasmi Roterodami - Opera Omnia - Recognita et adnotatione critica instrvcta notisque illvstrata, ed. Kazimierz Kumaniecki, Amsterdã, North-Holland Publishing Company Amsterdam, 1969.

Lins, Ivan; Erasmo, a Renascença e o humanismo, Rio de Janeiro, Civilização Brasileira, 1967.

Lohr, Charles H.; “Metaphysics” in The Cambridge History of Renaissance Philosophy Edited by Charles B. Schmitt and Quentin Skinner, Cambridge University Press, 1996.

Margolin, Jean-Claude; Douze annés de bibliographie érasmienne (1950-1961), Paris, Vrin, 1963; Quatorze annés de bibliographie érasmienne (1936-1949), Paris, Vrin, 1969; Neuf annés de bibliographie érasmienne (1962-1970), Paris e Toronto, Vrin e Toronto University Press, 1977.

Margolin, Jean-Claude; prefácio in Érasme - Les Silènes d'Alcibiade; Col. Le Corps Eloquent, Paris, Les Belles Lettres, 1998.

Margolin, Jean-Claude; prefácio Érasme, notre Contemporain in Coletânea R. Laffont. 
Ménager, Daniel; introdução aos Colóquios in Coletânea R. Laffont.

Mondolfo, Rodolfo; Sócrates, tradução de Lycurgo Gomes da Motta, São Paulo, Editora Mestre Jou, 1963.

Panofsky, Erwin; Renascimento e Renascimentos na Arte Ocidental, Porto, Editorial Presença, 1981.

Popkin, Richard H.; Histoire du Scepticisme d'Érasme a Spinoza - Traduction de Christine Hivet, Paris, Presse Universitaires de France, 1995.

Rico, Francisco; Il sogno dell'umanesimo - da Petrarca a Erasmo, Torino, Giulio Einaudi, 1998.

Schmitt, Charles B. e Skinner, Quentin; The Cambridge History of Renaissance Philosophy, Cambridge University Press, 1996.

Souza, Maria das Graças; Ilustração e História - o pensamento sobre a história no iluminismo francês, São Paulo, Discurso Editorial, 2001.

Vignal, L. Gautier; Érasme 1466 - 1536, Paris, Payot, 1936. 